
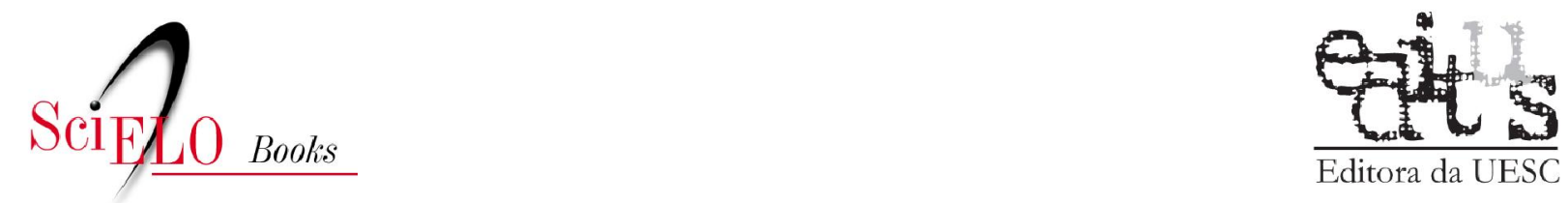

Editora da UESC

\title{
Métodos e técnicas de pesquisa em bacias hidrográficas
}

\author{
Maria Eugênia Bruck de Moraes \\ Reinaldo Lorandi \\ (orgs.)
}

MORAES, MEB., and LORANDI, R., orgs. Métodos e técnicas de pesquisa em bacias hidrográficas [online]. Ilhéus, BA: Editus, 2016, 283p. ISBN 978-85-7455-443-3. Available from SciELO Books $<\underline{\text { http://books.scielo.org }>\text {. }}$

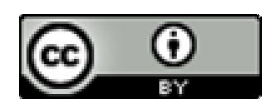

All the contents of this work, except where otherwise noted, is licensed under a Creative Commons Attribution 4.0 International license.

Todo o conteúdo deste trabalho, exceto quando houver ressalva, é publicado sob a licença Creative Commons Atribição 4.0 .

Todo el contenido de esta obra, excepto donde se indique lo contrario, está bajo licencia de la licencia Creative Commons Reconocimento 4.0. 


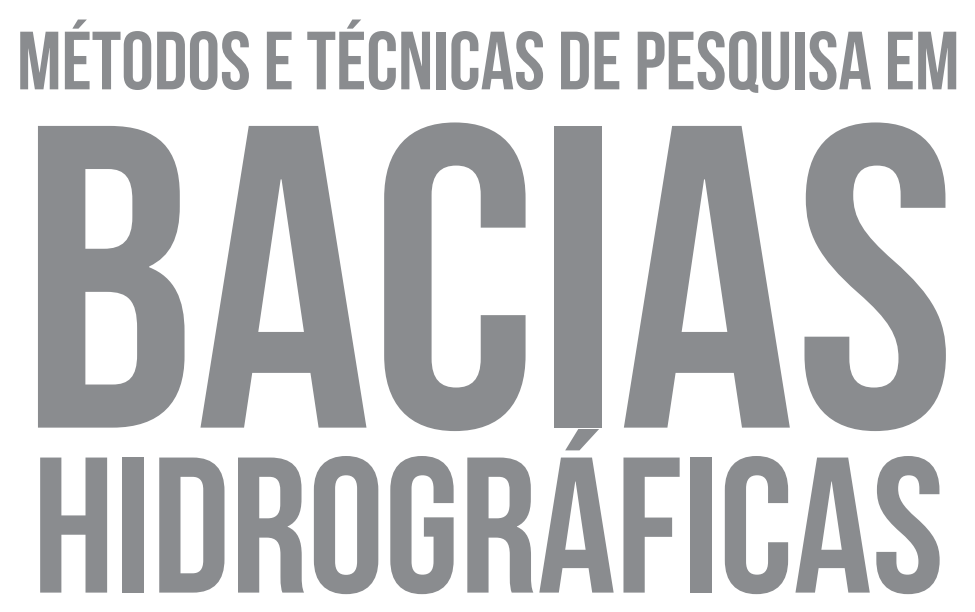




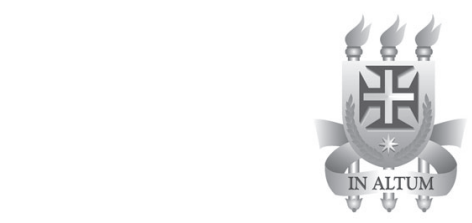

\section{Universidade Estadual de Santa Cruz}

\section{GOVERNO DO ESTADO DA BAHIA}

Rui Costa - Governador

\section{SECRETARIA DE EDUCAÇÁO}

Walter Pinheiro - Secretário

UNIVERSIDADE ESTADUAL DE SANTA CRUZ

Adélia Maria Carvalho de Melo Pinheiro - Reitora

Evandro Sena Freire - Vice-Reitor

\section{DIRETORA DA EDITUS}

Rita Virginia Alves Santos Argollo

\section{Conselho Editorial:}

Rita Virginia Alves Santos Argollo - Presidente

André Luiz Rosa Ribeiro

Andrea de Azevedo Morégula

Adriana dos Santos Reis Lemos

Evandro Sena Freire

Francisco Mendes Costa

Guilhardes de Jesus Júnior José Montival de Alencar Júnior

Lúcia Fernanda Pinheiro Barros

Lurdes Bertol Rocha

Ricardo Matos Santana

Rita Jaqueline Nogueira Chiapetti

Samuel Leandro Oliveira de Mattos

Sílvia Maria Santos Carvalho 
Maria Eugênia Bruck de Moraes e Reinaldo Lorandi (Organizadores)

\section{MÉTODOS E TÉCNICAS DE PESQUISA EM
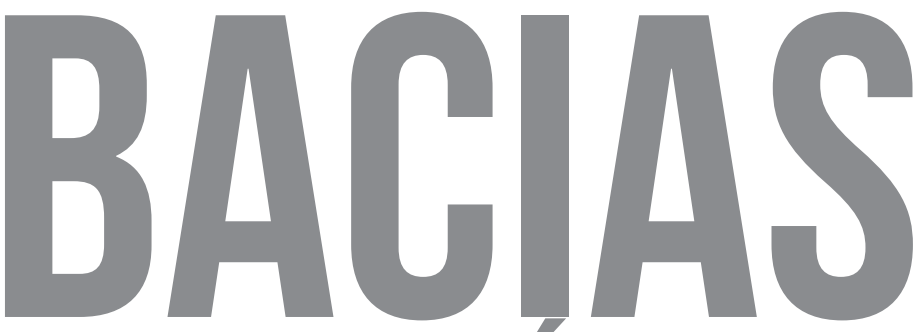 \\ HIDROGRAFICAS}

Ilhéus - Bahia

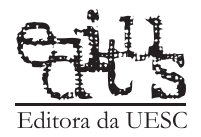

2016 
Copyright (C)2016 by Maria Eugênia Bruck de Moraes e Reinaldo Lorandi

Direitos desta edição reservados à

EDITUS - EDITORA DA UESC

A reprodução não autorizada desta publicação, por qualquer meio, seja total ou parcial, constitui violação da Lei nº 9.610/98.

Depósito legal na Biblioteca Nacional,

conforme Lei $n^{0}$ 10.994, de 14 de dezembro de 2004.

PROJETO GRÁFICO E CAPA

Álvaro Coelho

REVISÃO

Roberto Santos de Carvalho

FOTOGRAFIA DE CAPA

Rio Almada - Héctor Manuel Benavides

Dados Internacionais de Catalogação na Publicação (CIP)

M593 Métodos e técnicas de pesquisa em bacias hidrográ-

ficas / Maria Eugênia Bruck de Moraes, Reinaldo

Lorandi (organizadores). - Ilhéus, BA: Editus, 2016.

283 p. : II.

Vários autores.

Inclui referências.

ISBN 978-85-7455-424-2

1. Bacias hidrográficas - Manejo. 2. Bacias hidrográficas - Sensoriamento remoto. 3. Monitoramento ambiental. 4. Sistemas de informação geográfica. I. Moraes, Maria Eugênia Bruck de. II. Lorandi, Reinaldo.

EDITUS - EDITORA DA UESC

Universidade Estadual de Santa Cruz

Rodovia Jorge Amado, km 16 - 45662-900 - Ilhéus, Bahia, Brasil

Tel.: (73) 3680-5028

www.uesc.br/editora

editus@uesc.br

EDITORA FILIADA À

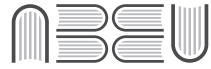

Associação Brasileira

das Editoras Universitárias 
Os rios são a mais importante fonte de água natural no Brasil e vêm sofrendo diversos problemas ambientais devido a ações humanas inadequadas. Essas alteraçóes nos ecossistemas fluviais têm sido uma preocupação constante de estudiosos de diversas áreas, como Ecologia, Geologia, Geografia e Agronomia, entre tantas outras.

Desde seu doutorado, sob a orientação do professor Reinaldo Lorandi, Maria Eugênia Bruck de Moraes vem estudando bacias hidrográficas, ao seu lado e de outros pesquisadores e estudantes. Durante esse período, ambos notaram que, apesar do número crescente de estudos sobre o tema, faltavam ainda publicaçóes que se detivessem mais profundamente nas diferentes abordagens teórico-metodológicas adotadas nessas pesquisas.

Ao organizarem o livro Métodos e técnicas de pesquisa em bacias hidrográficas, os pesquisadores não objetivaram dar conta de todas as abordagens voltadas para tal objeto de estudo, mas sim oferecer resultados consistentes obtidos por meio de pesquisas de campo e/ou do uso de geotecnologias.

Os capítulos deste livro apresentam e discutem diferentes métodos e técnicas de pesquisa, aplicados por pesquisadores em bacias hidrográficas. São abordados aspectos relevantes da análise, planejamento e manejo ambiental, visando minimizar os custos na manutenção ou recuperação dos ecossistemas produtores de serviços, como a água. Os dois primeiros capítulos tratam de conceitos e instrumentos básicos de pesquisa. E os seguintes apresentam estudos de caso sobre bacias hidrográficas localizadas nos estados da Bahia (capítulos 3 a 8) e São Paulo (capítulos 9 a 12), propondo soluçóes para os problemas encontrados. $\mathrm{O}$ último capítulo, também sobre uma bacia no estado de São Paulo, se detém mais especificamente na aplicação da legislação ambiental. 
Todos os capítulos foram escritos em coautoria entre pesquisadores com formaçáo em diferentes áreas do conhecimento e em diferentes fases da carreira, acadêmica ou não. Os organizadores acreditam que as diferentes perspectivas e especialidades ampliam o interesse pelo livro, sem perder a coerência quanto ao tema abordado.

Finalmente, destaca-se a exposição didática e bem ilustrada dos textos, sem perder o rigor científico, sendo de interesse para estudantes de graduação e pós-graduação, professores, pesquisadores e técnicos na área das ciências ambientais.

Maria Eugênia Bruck de Moraes e Reinaldo Lorandi 
Introdução

17 CAPÍTULO 1

Aquisição de dados geográficos em plataformas livres para estudos ambientais em bacias hidrográficas

CAPÍTULO 2

Bacia do rio Almada (Bahia): criação de cenários ambientais a partir do diagnóstico da fragmentação florestal

57 CAPÍTULO 3

Utilização de técnicas de mapeamento geotécnico para a avaliação da adequabilidade da bacia do Almada para implantaçáo de obras lineares

CAPÍTULO 4

Zoneamento geohidroecológico da bacia do rio Almada: análise da capacidade de produção de água

103 CAPÍTULO 5

Bacia do rio Buranhém: análise integrada da paisagem

CAPÍTULO 6

Aspectos geoambientais dos recursos hídricos das propriedades rurais do Projeto Barro Preto, Bahia

CAPÍTULO 7

Caracterização hidrológica e biogeoquímica de nitrogênio em microbacias: estudo de caso em áreas com diferentes usos do solo

163 CAPÍTULO 8

Limnologia de rios intermitentes: a bacia hidrográfica do rio Jequiezinho como estudo de caso

CAPÍTULO 9

Importância das florestas ripárias na melhoria da qualidade da água em bacias hidrográficas: estudos de caso na região central do estado de São Paulo 


\section{CAPÍTULO 10}

Ecologia da bacia do rio Itanhaém: características limnológicas e uso do solo

219 CAPÍTULO 11

Bacia do rio Corumbataí: uso do solo e características

limnológicas

241 CAPÍTULO 12

Cartografia geoambiental da bacia do rio do Monjolinho

(Sáo Paulo)

265 CAPÍTULO 13

A legislação ambiental da bacia do rio Claro, São Paulo

283 Sobre os autores 


\title{
Por que estudar bacias hidrográficas?
}

\author{
Maria Eugênia Bruck de Moraes
}

Os ambientes lênticos e lóticos foram usados até hoje para as mais diversas finalidades, tais como abastecimento de água, geração de energia, irrigação, pesca, navegação, aquicultura, dessedentação de animais, diluição de efluentes, atividades de esporte e lazer, entre outras. Observa-se, porém, que as sociedades atuais têm ampliado ainda mais tal diversidade de uso, gerando um quadro complexo e conflitivo pela excessiva demanda dos recursos hídricos. Lanna (1997), por exemplo, ressalta que, em regióes industrializadas de exploração mineral e com elevada concentração populacional, esses recursos são rapidamente degradados, comprometendo a qualidade da água.

$\mathrm{O}$ uso que demanda maior quantidade de água, segundo Esteves (2011), é a irrigação para produção de alimentos (70\%), seguida pelos usos industrial (23\%) e doméstico (7\%).

Conforme estimativa do Ministério do Meio Ambiente, a área irrigável brasileira em 2006 era de 29,6 milhões de hectares (MMA, 2006). Apesar disso, o elevado consumo de água nesse tipo de atividade deve ser também associado ao desperdício e à contaminação de águas superficiais e subterrâneas por agrotóxicos.

Já nos processos industriais, os usos da água variam muito de acordo com as tecnologias adotadas. Muitas vezes, a água resultante dessa atividade contém resíduos tóxicos, como materiais pesados, além de restos de materiais em decomposição na água usada para a fabricação de produtos, lavagem de materiais e equipamentos, em sistemas de refrigeração e na produção de vapor. Finalmente, quanto ao uso doméstico, dados da Agência Nacional de Águas (ANA) mostraram que, aproximadamente, metade dos 5.565 municípios analisados pelo Atlas Brasil deveria investir um total de 22,2 bilhóes de reais no setor de abastecimento até 2015 , de modo a garantir a oferta 
adequada de água (ANA, 2011). O fato, porém, é que a contaminação do sistema público de abastecimento de água por efluentes não tratados compromete, na maioria das vezes, o seu uso, devido ao aumento da incidência de doenças de veiculaçáo hídrica.

O homem é o principal agente modificador dos ciclos de evolução natural. A poluição do meio ambiente é sem dúvida um dos maiores problemas causados pelo descontrole das atividades antrópicas, podendo levar à destruição de todo um sistema. Nesse sentido, a contaminação da água por seu uso ilimitado e desordenado resulta num ciclo vicioso, muitas vezes, difícil de ser revertido. Segundo Brigante et al. (2002), diferentes atividades antrópicas aumentam a concentração de nutrientes nos ecossistemas aquáticos, especialmente de fósforo e nitrogênio, levando ao processo de eutrofização artificial.

Apesar de importante para a produçáo primária de um rio, o fósforo em alta concentraçáo altera a qualidade da água, comprometendo seu uso. Já o excesso de nutrientes nitrogenados leva ao desequilíbrio dos sistemas ecológicos do rio; sem falar que o nitrogênio pode adquirir formas tóxicas para muitas espécies. A modificação dos ciclos nutritivos de um ecossistema é, em grande parte, consequência da ignorância humana sobre a complexidade das unidades funcionais deste.

Como alertam Tundisi e Matsumara-Tundisi (2008), as tantas interferências ocorridas em corpos d'água produzem alteraçóes drásticas na estrutura e funcionamento dos ecossistemas. Além disso, não se pode desconsiderar o papel essencial da água na manutenção dos ecossistemas e para a sobrevivência da fauna e da flora. Por isso, a degradaçáo dos recursos hídricos pelo afluxo de matéria orgânica ou inorgânica não assimilável e sem atenção aos ciclos renováveis da água causa impactos que excedem seus componentes bióticos e abióticos. Segundo Esteves (2011), além de modificaçôes profundas nas comunidades aquáticas, nas características físicas e químicas da água e no nível de produção do sistema, o processo de eutrofização, seja este artificial ou natural, altera o metabolismo de todo o ecossistema, com uma série de consequências socioeconômicas.

Atualmente, a gestão de recursos hídricos no Brasil tem se baseado na aplicação dos instrumentos da Política Nacional de Recursos Hídricos (PNRH), promulgada em 1997 pela Lei Federal 9.433 (BRASIL. Lei 9.433/1997, alterada pela Lei 9.984/2000). Entretanto, o país enfrenta 
dificuldades com a consolidação dos aspectos institucionais do gerenciamento, o controle da exploração desses recursos nas metrópoles e da poluição difusa sobre os recursos hídricos, bem como a conservação ambiental.

Com a promulgação da $\mathrm{PNRH}$, a bacia hidrográfica passa a ser considerada a unidade territorial ideal para o gerenciamento da água, levando à implementação do Sistema Nacional de Gerenciamento de Recursos Hídricos (SNGRH). Com isso, reconhece-se a opção do governo brasileiro pelo uso de entidades sistêmicas de gestão.

A aplicação do conceito de bacia hidrográfica como unidade de estudo e de gerenciamento dos recursos hídricos tem origem na constatação dos pesquisadores de que os ecossistemas aquáticos são essencialmente abertos, trocam matéria e energia entre si e com os ecossistemas terrestres adjacentes. Em se tratando de sistemas lóticos (interligados), como as redes de drenagem, tais trocas são determinadas pelas características fisiográficas da bacia (ROCHA; PIRES; SANTOS, 2000).

Ao longo do tempo, muitos conceitos de bacia hidrográfica foram propostos por diferentes autores. $\mathrm{O}$ conceito de bacia hidrográfica é relativamente simples, mas pode-se defini-lo em quase qualquer escala, visto que uma bacia pode variar de tamanho desde a área de drenagem de um rio de primeira ordem até bacias com rios de $12^{\mathrm{a}}$ ordem ou mais, como os rios Amazonas e Mississipi. Com a exceção das bacias sem drenagem externa e daquelas que drenam diretamente para o oceano, todas as bacias estáo inseridas em outras maiores.

É reconhecido que a bacia hidrográfica deve ser entendida como um sistema interligado, sendo que a subdivisão de grandes bacias em bacias menores (sub-bacias) facilita o diagnóstico e o monitoramento ambiental, visto que isto permite a correlação das análises da qualidade da água com a dinâmica do uso e ocupação do solo, assim como a delimitação de áreas críticas e a identificação de processos impactantes.

O conceito de bacia hidrográfica tem sido expandido na medida em que o seu uso cresce nas pesquisas científicas e nos programas governamentais de ordenamento territorial. Rocha, Pires e Santos (2000), Pires, Santos e Del Prette (2002) e Souza e Tundisi (2004) ressaltam que do ponto de vista do planejamento ambiental, o conceito de bacia tem sido cada vez mais utilizado com uma abrangência além dos aspectos hidrológicos, envolvendo o conhecimento da sua estrutura biofísica, a evolução do uso do solo e suas implicaçóes ambientais. 
Como já destacava Margalef (1983), a qualidade das águas superficiais funciona como indicativo da dinâmica de uma bacia hidrográfica. Mas, além da massa de água, o conhecimento das atividades desenvolvidas na bacia também é imprescindível para os estudos sobre as características e alterações na qualidade da água e para a prevenção de problemas de poluição que possam vir a comprometer o aproveitamento múltiplo da mesma.

Outra informaçáo importante diz respeito ao monitoramento da cobertura vegetal, posto que a presença da mesma contribui para o ajustamento das variáveis internas dos ecossistemas aquáticos e a manutenção do equilíbrio do regime hidrológico da bacia hidrográfica.

Callisto e Gonçalves (2005) enfatizam que a preservação da mata ciliar está associada à manutenção de várias funçôes e serviços ecológicos. Em se tratando de ambientes aquáticos, a mata ciliar funciona como zona tampão, atuando como filtro contra poluentes, e fonte de troca de matéria, energia e organismos.

A sustentabilidade de um ecossistema ou de um conjunto de ecossistemas (como ocorre em uma bacia hidrográfica) depende de uma adequada exploração e gestão dos recursos naturais; assim, Lorandi e Cançado (2002) enfatizam que o gerenciamento de uma bacia está diretamente relacionado ao planejamento adequado do uso dos seus recursos, integrado às atividades antrópicas que ali ocorrem.

Diante da necessidade de integraçáo de tantas variáveis, o uso de produtos oriundos do sensoriamento remoto e a aplicaçáo de técnicas de geoprocessamento a partir da utilizaçáo de um Sistema de Informação Geográfica (SIG) tornam-se cada vez mais essenciais. Becker (2002), ao discutir a aplicação do SIG nos estudos de ecologia e manejo de bacias, enfatiza ainda a possibilidade de se trabalhar com escalas espaciais e temporais mais abrangentes, bem como a integração de múltiplas escalas; necessária, muitas vezes, para a compreensão de processos ecológicos e antrópicos que ocorrem em escalas diferentes. Deste modo, no próximo capítulo serão discutidas diferentes possibilidades de uso das ferramentas de geotecnologia nas pesquisas realizadas em bacias hidrográficas. 


\section{REFERÊNCIAS}

AGÊNCIA NACIONAL DE ÁGUAS (ANA). Conjuntura dos recursos hídricos no Brasil: informe 2011. Brasília: Agência Nacional de Águas, 2011.

BRASIL. Lei 9.433, de 8 de janeiro de 1997. Dispõe sobre a Política Nacional de Recursos Hídricos. Disponível em: <http://www.sigrh.sp. gov.br/sigrh/basecon/Irh2000/indicelf.htm>. Acesso em: 15 jun. 2015.

BRASIL. Lei 9.984, de 17 de julho de 2000. Dispóe sobre a criação da Agência Nacional de Águas (ANA), entidade federal de implementação da Política Nacional de Recursos Hídricos e de coordenação do Sistema Nacional de Gerenciamento de Recursos Hídricos, e dá outras providências. Disponível em: <http://www.planalto.gov.br/ccivil_03/leis/19984. htm>. Acesso em: 22 mar. 2015.

BECKER, F. G. Aplicaçóes de sistemas de informação geográfica em ecologia e manejo de bacias hidrográficas. In: SCHIAVETTI, A.; CAMARGO, A. F. M. (Eds.) Conceitos de bacias hidrográficas: teorias e aplicações. Ilhéus, BA: Editus, 2002. p. 91-123.

BRIGANTE, J. et al. Avaliaçáo ambiental do rio Moji-Guaçu: resultados de uma pesquisa com abordagem ecossistêmica. São Carlos, SP: Rima, 2002.

CALLISTO, M.; GONÇALVES, J. F. J. Bioindicadores bentônicos. Impactos ambientais em ecossistemas aquáticos continentais. In: ROLAND, F.; CESAR, D.; MARINHO, M. (Orgs.) Liçóes de limnologia. São Carlos, SP: Rima, 2005. p. 371-379.

ESTEVES, F. A. Fundamentos de limnologia. 3. ed. Rio de Janeiro: Interciência, 2011.

LANNA, A. E. L. Gestão dos recursos hídricos. In: TUCCI, C. E. M. (Org.) Hidrologia: ciência e aplicação. 2. ed. Porto Alegre: ABRH, 1997.

LORANDI, R.; CANÇADO, C. J. Parâmetros físicos para gerenciamento de bacias hidrográficas. In: SCHIAVETTI, A.; CAMARGO, A. F. M. (Eds.) Conceitos de bacias hidrográficas: teorias e aplicações. Ilhéus, BA: Editus, 2002. p. 37-65. 
MARGALEF, R. Limnologia. Barcelona: Omega, 1983.

MINISTÉRIO DO MEIO AMBIENTE (MMA). Caderno setorial de recursos hídricos: agropecuária. Brasília, DF: SRH/MMA, 2006.

PIRES, J. S.; SANTOS, J. E. dos; DEL PRETTE, M. E. A utilização do conceito de bacia hidrográfica para a conservação dos recursos naturais. In: SCHIAVETTI, A.; CAMARGO, A. F. M. (Eds.) Conceitos de bacias hidrográficas: teorias e aplicações. Ilhéus, BA: Editus, 2002 p. 1735.

ROCHA, O.; PIRES, J. S. R.; SANTOS, J. E. A bacia hidrográfica como unidade de estudo e planejamento. In: ESPÍNDOLA. E. L. G.; SILVA, J. S. V.; MARINELLI, C. E.; ABDON, M. M. (Orgs.) A bacia hidrográfica do rio Monjolinho. São Carlos, SP: Rima, 2000. p. 1-16.

SOUZA, A. D. G. de; TUNDISI, J. G. Integração entre a gestão ambiental e a gestão de recursos hídricos. Estudo de caso: bacia hidrográfica do Rio Jaboatão, PE. In: SANTOS, J. E.; CAVALHEIRO, F.; PIRES, J. S. R.; OLIVEIRA; C. H.; PIRES, A. M. Z. C. R. (Orgs.) Faces da polissemia da paisagem: ecologia, planejamento e percepção. São Carlos, SP: Rima, 2004. p. 151-176.

TUNDISI, J. G.; MATSUMURA-TUNDISI, T. Limnologia. São Carlos, SP: Oficinas de Texto, 2008. 


\section{Aquisiçáa de dados geográficos em plataformas livres para estudos ambientais em bacias hidrográficas}

Carlos Wilmer Costa

Luiz Eduardo Moschini

Reinaldo Lorandi

\section{Introduçáo}

Por muito tempo, as economias dos países têm estado centradas na exploraçáo de serviços ecossistêmicos como o fornecimento de alimentos, energia, recursos minerais e água. Porém, tal modelo de desenvolvimento mostra-se precário e gera incertezas quanto a sua sustentabilidade (MILLENNIUM ECOSYSTEM ASSESSMENT, 2005; RAVENGA, 2005).

Em se tratando de recursos hídricos, o desenvolvimento insustentável, aliado à falta de planejamento em todos os níveis, tem afetado a sua disponibilidade e qualidade, comprometendo a capacidade de beneficiar um número maior de pessoas. Atualmente, segundo o United Nations World Water Assessment Programme, 1,2 bilhão de pessoas têm dificuldades de acesso à água de boa qualidade e, como agravante, a demanda mundial por água deverá aumentar em até $55 \%$ até 2050. A menos que se busque um equilíbrio entre demanda e disponibilidade, o mundo terá de enfrentar um déficit hídrico cada vez maior (WWAP, 2015).

Paralelamente, a agricultura é responsável pelo uso de $70 \%$ da água retirada de aquíferos, rios e lagos, sendo que nos últimos 50 anos a área irrigada mais que dobrou. De acordo com a Food and Agriculture Organization of the United Nations, para 2050, é esperado um aumento de 70\% na produção mundial de alimentos; e nos países em desenvolvimento esse aumento poderá ser de $100 \%$, o que deve agravar a escassez hídrica (FAO, 2011). Além disso, de acordo com a International Energy Agency, também 
é esperado um aumento de $20 \%$ na utilização da água para geração de energia até 2035 (IEA, 2012). Com relação às águas subterrâneas, as quais são intrinsecamente ligadas às superficiais, calcula-se que $20 \%$ dos aquíferos são sobreutilizados, levando a um declínio dos níveis piezométricos (CAMP; WALRAEVENS, 2008).

Diante deste cenário de comprometimento e, ao mesmo tempo, de desconfianças quanto à sustentabilidade hídrica atual e futura, a adoção da bacia hidrográfica como unidade de planejamento é um instrumento de gerenciamento de uso e ocupação do solo com aceitação global, contribuindo para a conservação dos recursos hídricos.

Segundo Tucci e Mendes (2006), todas as superfícies destinadas a áreas urbanas e industriais, agropecuária ou preservação estão inseridas em alguma bacia hidrográfica. No seu exutório, por meio do rio principal, dá-se o resultado da interconexão entre o meio físico e as atividades antrópicas, isto é, ali estáo representadas as consequências das formas de uso e ocupação do solo. No Brasil, desde a promulgação da Lei Federal 9.433, de 1997, e da Resoluçáo 001, de 1986, do Conselho Nacional de Meio Ambiente (CONAMA), a bacia hidrográfica é considerada como unidade de planejamento. Em ambiente acadêmico, os estudos que adotam a bacia hidrográfica como unidade de planejamento são expressivos, abrangendo temas variados. Além disso, muitos desses estudos têm como objetivo auxiliar os tomadores de decisão no planejamento ambiental.

$\mathrm{Na}$ perspectiva moderna, tendo por base a necessidade de se realizar uma análise ambiental integrada com vistas ao planejamento e gestáo de bacias hidrográficas, toda ação de planejamento do território deve incluir os meios físico, biótico e antrópico, bem como suas inter-relaçóes. Entre as geotecnologias empregadas na análise ambiental integrada, McKinney et al. (1999) enfatizam que o uso de Sistemas de Informação Geográfica (SIG) é de grande relevância. Medeiros e Câmara (2001) apontam que, em pelo menos cinco áreas de estudos ambientais, é cada vez maior o uso do SIG: mapeamento temático (como os de geologia, geomorfologia, solos e cobertura vegetal), diagnóstico ambiental, avaliaçáo de impacto ambiental, ordenamento territorial e prognósticos ambientais.

Para alimentar um banco de dados em ambiente SIG, são necessárias informações espaciais. Normalmente, os dados espaciais têm sido fornecidos de duas formas: impressos ou em formato digital. Nas últimas décadas, a web tem exercido um papel importante na difusão e acesso 
a dados digitais, liberados por diferentes instituições governamentais e privadas (CULSHAW; JACKSON; GILLES, 2006). Segundo Carvalho e Di Maio (2011), grande parte das informaçóes ambientais pode ser adquirida por meio de web-services em plataformas livres (open access), o que torna possível para pesquisadores, planejadores ou outros interessados a obtenção de dados secundários com maior facilidade. Por exemplo, as imagens de satélites, disponibilizadas e atualizadas diariamente, fornecem dados consistentes da superfície da Terra, permitindo aos cientistas detectar mudanças e tendências no ambiente (FLORENZANO, 2005). No Brasil, as principais fontes de dados secundários ambientais estáo vinculadas a órgãos governamentais tanto federais quanto estaduais. Nos sites desses órgãos é disponibilizado um amplo banco de dados georreferenciados para download.

$\mathrm{O}$ acesso e o fornecimento de informaçóes aos usuários pelas plataformas de dados dependem de variáveis como a qualidade dos dados, a escala espacial e temporal e acordos sobre o uso de dados; sendo ainda que os mesmos devem estar tanto quanto possível disponíveis para uso em um SIG (ROEHRIG, 2002). Outra dificuldade é como lidar com tal riqueza de informaçóes, visto que os arquivos de dados possuem diversos formatos e o pesquisador nem sempre está familiarizado com tais extensōes. $\mathrm{Na}$ prática, observa-se uma grande variedade de formatos para armazenar e disponibilizar os dados, o que exige a leitura e conversão desses dados (ALMEIDA et al., 2009).

Nesse contexto, este capítulo apresenta fontes e métodos para aquisição de dados geográficos disponíveis para download em plataformas livres na web e que podem ser utilizados em estudos de bacias hidrográficas. A fim de atingir tal objetivo, faz-se num primeiro momento a diferenciação entre dados vetoriais e matriciais (raster), incluindo exemplos de formatos de arquivos mais utilizados em ambiente SIG. No momento seguinte, é discutida a obtenção de dados relevantes para estudos ambientais, como: limites de municípios brasileiros, cartas topográficas, mapas geológicos, mapas pedológicos, unidades de conservação, imóveis rurais certificados, rede de drenagem e sub-bacias do estado de São Paulo, Modelo Digital de Elevaçáo (MDE) para todo o Brasil, formas das encostas, imagens de satélites e dados censitários. 


\section{Aquisiçáo de dados vetoriais e matriciais}

Neste ponto, há de se fazer uma distinção fundamental de como os dados de mapas são representados: na sua forma vetorial e matricial. Alguns tipos de dados estão associados a certos tipos de representaçóes. Por exemplo:

Mapas temáticos: podem ser tanto matriciais como vetoriais;

Mapas cadastrais: seus temas estấo vinculados a coordenadas vetoriais e a um banco de dados onde são armazenadas as informaçôes não gráficas;

Imagens de sensoriamento remoto: representação matricial;

Modelos Digitais de Elevaçáo (MDE): podem ser matriciais ou grades triangulares (vetorial).

A seguir, segue uma breve descrição das formas de representação vetorial e matricial. Com isso, será possível verificar a diferença entre os tipos de dados geográficos que podem alimentar um banco de dados no SIG.

$\mathrm{Na}$ representação vetorial, os limites das feiçóes são definidos por uma série de pontos que, quando unidos, formam o desenho gráfico de cada feiçáo. Os pontos sáo codificados com um par de números representando as coordenadas $\mathbf{x}$ e $\mathbf{y}$ em sistemas como latitude/longitude ou em UTM (Universal Transversa de Mercator). Uma sequência aberta de pares ordenados de vértices pode criar uma linha; e uma sequência fechada, um polígono. Cada um desses objetos espaciais pode estar ligado a um banco de dados com informações das feiçōes (EASTMAN, 1995; CHEN; WEN; YUE, 2014).

Os dados vetoriais podem ter diferentes formatos de representação. Dentre os padróes mais comuns estão as extensôes .shp, .dwg, .dxf, .kml e . .kmz.

Os dados derivados de programas como o CAD (Computer Aided Design) são armazenados sempre em arquivos únicos. Diferentemente, os dados provindos de SIG estão sempre acompanhados de vários arquivos, pois armazenam várias informaçóes, como por exemplo, de geometria (pontos, linhas ou polígonos), das feições (que estão ligadas a um banco de dados e geralmente estáo na forma de tabela - .dbf) e de definição do sistema de projeção cartográfica (coordenadas geográficas).

Globalmente, o shapefile (extensão .shp) é o formato vetorial mais utilizado. Esse formato foi originalmente desenvolvido pela empresa Environmental Systems Research Institute (ESRI), criadora do SIG ArcGIS. 
Atualmente, o formato shapefile é suportado por diversos programas de geoprocessamento, como o Quantum GIS e muitos outros. Como dito anteriormente, por ser criado em ambiente SIG, o formato shapefile é composto por vários arquivos distintos (extensōes .dbf, .prj, .sbn, .sbx, .shp, .shx). Cada um tem uma função específica e armazena um tipo de informação.

A extensáo .dwg (Autodesk's Design Web Format) corresponde ao formato padrão, no qual são feitos todos os desenhos básicos no software AutoCAD. A Autodesk criou o .dwg em 1982 ao lançar a primeira versão do AutoCAD, e ele contém todas as informaçóes inseridas pelo usuário.

A extensão .dxf (Drawing Exchange Format) corresponde ao formato de exportação de arquivos CAD. A intenção inicial da Autodesk era fornecer uma representação exata dos dados produzidos no AutoCAD, mas atualmente esse formato tornou-se padrão mundial na exportação de dados vetoriais. Normalmente, desde que se faça a conversão dos dados, não há problemas de compatibilidade entre diferentes SIG.

De acordo com a Open Geospatial Consortium, a Google apresentou o formato KML (Keyhole Markup Language) como padrão internacional para exibir dados geográficos em navegadores on-line como o Google Earth e o Google Maps. O formato KML permite que se trace diretamente no Google Earth pontos, linhas e polígonos e os compartilhe, reciprocamente, com outros aplicativos (OGC, 2015). Segundo a Google, neste formato, os dados científicos, como mapas de recursos naturais ou tendências geográficas, podem ser facilmente compartilhados. Os arquivos em extensão . $\mathbf{k m z}$ permitem que se empacote vários arquivos juntos, comprimindo o conteúdo para tornar o download mais rápido. Deste modo, pode-se agrupar imagens ao arquivo KML (GOOGLE, 2015).

No sistema matricial, a área de estudo é subdividida numa grade de células uniformes (picture element-pixel). As grades de dados podem ser como imagens ou planos de informação e são incapazes de fornecer informação em resolução mais fina do que a célula individual. Os sistemas matriciais têm poder analítico substancialmente maior que os sistemas vetoriais em relação ao espaço contínuo. E também são os mais adequados no estudo de dados que variam continuamente no espaço (CÂMARA; DAVIS; MONTEIRO, 2001; MALCZEWSKI, 2004).

Os arquivos matriciais podem ser armazenados e utilizados em diferentes formatos, com maior ou menor qualidade de imagem. Pode-se, por 
exemplo, variar entre centenas e até milhares de cores; o que, por sua vez, chega a aumentar consideravelmente o tamanho do arquivo. Ritter e Ruth (1997), Vinhas (2006), Siqueira (2008) e OGC (2015) esclarecem sobre os formatos mais comuns para representação matricial de dados geográficos: TIFF, GeoTIFF e JPEG.

A extensão .tif ou .tiff (Tagged Image File Format) foi desenvolvida como formato padrão de imagens no ambiente comercial. Tal formato oferece grande variedade de cores e excelente qualidade de imagem, o que aumenta consideravelmente o tamanho dos arquivos. Embora possam ser compactados sem perda de informação.

A extensão .geotiff é específica para o armazenamento de dados matriciais geográficos. A diferença é que nessa extensão são definidas as informaçôes cartográficas e geodésicas associadas a uma imagem TIFF. Dessa forma, o conteúdo de uma imagem GeoTIFF inclui sua projeção cartográfica, Datum e outras variáveis geográficas. Nos dias atuais, essa extensão é aceita globalmente como padrão de intercâmbio de dados matriciais.

A extensão .jpg ou .jpeg (Joint Photographic Experts Group) corresponde a um dos formatos mais populares da web por aliar duas características importantes: oferece níveis razoáveis de qualidade de imagem e gera arquivos de tamanho pequeno quando comparados a outros formatos, facilitando o armazenamento e distribuição.

A seguir, em virtude da variedade dos dados secundários disponíveis, optou-se por apresentar a forma de aquisição dos mesmos, separadamente, em três itens.

\section{Aquisiçáo de dados vetoriais}

Aqui são listadas maneiras de se obter dados geográficos no formato vetorial.

No Brasil, a principal fonte de dados cartográficos é o Instituto Brasileiro de Geografia e Estatística (IBGE). No site deste instituto, na seção "Geociências", sob a aba "Downloads", estão disponibilizadas algumas opçóes de dados na forma de pastas. Por exemplo, na pasta "malhas digitais", acessando a subpasta "município_2013”, pode-se fazer o download dos limites dos municípios brasileiros. Estes arquivos estão compactados (.zip) e organizados em outras subpastas para cada Unidade da Federação. Depois de descompactados, eles aparecem no formato shapefile. Após cada criação 
de novos municípios ou realização do censo, o IBGE lança uma nova malha digital com os limites municipais atualizados. Normalmente, opta-se pelos dados mais recentes, que já utilizam o SIRGAS 2000 como sistema geodésico de referência espacial.

Vale ressaltar que, a partir de fevereiro de 2015, o Sistema de Referência Geocêntrico para as Américas (SIRGAS 2000) passou a ser o sistema geodésico de referência adotado oficialmente no Brasil (IBGE, 2015). A diferença entre os sistemas de referência anteriormente adotados (Córrego Alegre e South American Datum 1969 - SAD 69) e o SIRGAS 2000 é que: os primeiros adotavam uma definição/orientação topocêntrica, na qual o ponto de origem e orientaçáo está na superfície terrestre; enquanto, no segundo, a definição/orientação é geocêntrica, na qual a origem dos seus três eixos cartesianos é localizada no centro de massa da Terra. Além disso, enquanto que para os sistemas anteriormente adotados foram utilizadas técnicas de triangulação e poligonação, no SIRGAS 2000, foram empregados os sistemas globais de navegação (posicionamento) por satélites, Global Navigation Satellite Systems (GNSS) (IBGE, 2005).

As cartas topográficas na escala 1: 50.000 são de extrema importância, pois contêm informações de curvas de nível, rede hidrográfica, malha viária, entre outras. Elas também servem de base cartográfica para diferentes mapas temáticos, como os geológicos, geomorfológicos, pedológicos, entre muitos outros.

Para ter acesso às cartas topográficas no formato vetorial, deve-se seguir os seguintes passos: no site do IBGE, acessar a opção "Produtos e Serviços" sob a aba "Canais", seguidas de "Loja Virtual" e "Procure na Loja". Neste campo, deve-se escrever o nome ou código da carta topográfica de interesse e clicar em "Ok”. Como resultado da busca, aparecerá a carta; e, clicando sobre ela, surgirá uma opção para download gratuito. Clicando em download, deve-se optar, entre os formatos disponíveis, por DGN (DesiGN file), que corresponde ao formato de arquivo CAD. Lembrando que estes dados estáo compactados.

Depois de descompactá-los, são gerados oito arquivos vetoriais para cada carta topográfica, agrupados nas seguintes categorias: hidrografia (hd), hipsografia (hp), sistema viário (sv), localidade (lc), obra e edificação (oe), ponto de referência (pr), limite $(\mathrm{lm})$ e vegetaçáo (vg). Vale mencionar que algumas das informaçôes estão defasadas, como é o caso do sistema viário e obra e edificação (dados de 1971). Outros dados, como hipsometria e hidrografia, ainda podem ser utilizados. 
Também é importante destacar que, ao vetorizar as cartas topográficas, o IBGE adotou o Datum SAD 69, que era um dos sistemas geodésicos de referência utilizado no Brasil. Tal sistema utiliza o metro (m) como unidade de projeçáo. No entanto, o IBGE utilizou quilômetro $(\mathrm{km})$ como sistema de medida para vetorizaçáo das cartas. Por isso, no SIG, é preciso alterar a unidade de medida do Datum SAD 69 de "metros" para "quilômetros". Na sequência, deve-se converter os dados vetoriais para o Datum SIRGAS 2000.

O próximo passo refere-se à conversão dos dados vetoriais de DGN (.dgn) para qualquer um dos formatos compatíveis com o SIG utilizado. No caso do ArcGIS 10.2, os arquivos devem ser convertidos para o formato shapefile (ESRI, 2013). Antes de fazer o uso destas cartas, recomenda-se acessar o memorial descritivo em http://www.ibge.gov.br/home/geociencias/cartografia/vetori.shtm. Nas "Especificações Técnicas de Vetorização das Cartas Topográficas", pode-se encontrar a metodologia adotada para vetorização das cartas topográficas (IBGE, 2014).

Conhecimentos básicos sobre a utilização do Geobank (Banco de Dados de Informação Geocientífica) estão disponíveis no site da Companhia de Pesquisa de Recursos Minerais (CPRM): www.cprm.gov.br. Localize o Geobank (http://geobank.cprm.gov.br.) no menu em destaque no lado direito da tela. Nele é disponibilizada uma base de dados e mapas para obtenção de geoinformações como: Mapas de Geodiversidade, Mapas Geológicos dos Projetos da CPRM e de convênios com universidades nas escalas 1: 250.000 e 1: 100.000, Mapas Geológicos Estaduais, Mapas Hidrogeológicos, Mapa Geológico do Brasil nas escalas 1: 1.000 .000 e 1: 2.500.000, entre outros.

A opção "Downloads" possibilita as seguintes escolhas: arquivos vetoriais (mapas temáticos em formato shapefile), arquivos no formato KML e mapas em PDF. E também é possível consultar "notas explicativas", que são os relatórios técnicos dos mapas.

Os arquivos no formato shapefile encontram-se compactados. Depois de descompactá-los, numa pasta de sua preferência, eles estarão prontos para serem manipulados no aplicativo ArcGIS. Ao abrir os arquivos KML, estes serão visualizados diretamente no aplicativo Google Earth.

A CPRM também disponibiliza em torno de 100.000 documentos, incluindo mapas e relatórios técnico-científicos, que podem ser livremente acessados através do ícone "Biblioteca Virtual - Acesso Livre". 
Os arquivos vetoriais no formato shapefile, acompanhados de um banco de dados das unidades de conservação brasileiras estáo disponíveis para download por meio do aplicativo on-line "i3Geo" (Interface Integrada para Internet de Ferramentas de Geoprocessamento) disponível em: $\underline{\text { http:// }}$ mapas.mma.gov.br/i3geo/mma/openlayers.htm?855m1oii56mm70irt37p0f9s91 (MMA, 2015). A partir deste, na aba "Aplicativos", seleciona-se a opçáo "Download de Dados", onde pode-se encontrar uma lista de temas disponíveis. $\mathrm{Na}$ árvore de opções apresentada, seleciona-se "Áreas Especiais" e, posteriormente, "Unidades de Conservação (UCs)". A seguir, abrir-se-á uma janela para obtenção dos arquivos individualmente; sendo que também existe a opçáo de fazer o download de um único arquivo com todas as Unidades de Conservação. Ainda dentro da opção "Áreas Especiais", na seção "Outras áreas", o usuário tem acesso aos polígonos representativos das Terras Indígenas, Sítios Geológicos, Florestas Públicas e Geoparques.

Cabe ressaltar que no SIG utilizado, deve-se atribuir um sistema geodésico de referência, e, neste caso, utiliza-se o Datum World Geodetic System 1984 (WGS 84). Em seguida, os dados obtidos devem ser convertidos para o Datum SIRGAS2000.

Segundo o Instituto Nacional de Colonização e Reforma Agrária (INCRA), a certificação dos imóveis rurais, criada pela Lei 10.267, de 2001, garante que os limites de determinado imóvel não se sobreponham a outros e que o georreferenciamento seja realizado de acordo com as especificaçôes técnicas legais (INCRA, 2015).

As poligonais representativas dos imóveis rurais podem ser consultadas, assim como pode ser feito seu download em: http://acervofundiario. incra.gov.br/i3geo/interface/incra.html?0lm42pv8i87e0voqldsr46f6s0.

Os dados, em formato shapefile, estáo disponíveis na aba "Aplicativos", acessando a opção "Download de Dados". Na árvore exibida, deve-se optar por "Certificação de Imóveis Rurais" e "Convênios Regularização". Toda a rede de drenagem do Estado está disponível para download, em formato shapefile, no site da Coordenadoria de Planejamento Ambiental da Secretaria de Meio Ambiente do Estado de São Paulo (http://www. ambiente.sp.gov.br/cpla/cessao-de-dados), onde os arquivos estão compactados (SÁO PAULO. SMA, 2013a).

Após descompactados, eles aparecem em três grupos: no primeiro grupo, encontra-se toda a rede de drenagem do estado de Sáo Paulo em coordenadas geográficas (lat/long), Datum SIRGAS2000. Já nos outros dois 
grupos, o Estado é dividido entre os fusos $22 \mathrm{~S}$ e $23 \mathrm{~S}$, sendo que os dados estão em UTM, Datum SIRGAS2000.

A rede de drenagem foi gerada por processo automático em ambiente SIG, tendo como base o MDE (Modelo Digital de Elevação), elaborado a partir das curvas de nível das cartas 1: 50.000; por esse motivo, pode haver uma generalização e ocultação de certos cursos d'água, havendo a necessidade de supervisão (SÃO PAULO. SMA, 2013a).

Os arquivos das sub-bacias hidrográficas do estado de São Paulo estão disponíveis para download no site da SMA/CPLA (http://www.ambiente. sp.gov.br/cpla/sub-bacias-do-estado-de-sao-paulo). Tais arquivos encontram-se compactados para download e, depois de descompactados, estarão disponíveis em extensão .shp.

As sub-bacias foram delimitadas de forma automática, com auxílio da ferramenta ArcHydro do ArcGIS. A partir dos rios principais de cada Unidade de Gerenciamento dos Recursos Hídricos (UGRHI), foram identificados os afluentes e delimitadas as sub-bacias (SÃO PAULO. SMA, 2013b).

Para o uso desses dados e a correção de possíveis distorções quanto aos limites das sub-bacias hidrográficas, é recomendável proceder o controle manual com digitalização em tela, conforme proposto por Jansen (2009), utilizando como plano de fundo as cartas topográficas.

\section{Aquisição de dados matriciais}

A seguir são apresentados exemplos de como coletar dados no formato matricial de diferentes atributos ambientais. Por iniciativa da Comissão Europeia, um importante acervo de mapas pedológicos abrangendo a América Latina está disponível para download em: http://www.eusoils.jrc. ec.europa.eu/esdb_archive/eudasm/latinamerica/lists/cbr.htm.

Tal levantamento de dados intitula-se "European Digital Archive of Soil Maps (EuDASM) - Soil Maps of Latin America and Caribbean Islands" (SELVARADJOU et al., 2005) e conta com 1.060 mapas, dentre os quais 327 compreendem o território brasileiro. Estes incluem 37 mapas na escala maior que $1.1 .000 .000,258$ na escala de $1: 250.000$ a $1: 1.000 .000$, 13 na escala de $1: 100.000$ a 1: $250.000,18$ na escala de $1: 25.000$ a $1:$ 100.000 e um mapa na escala 1: 25.000. Boa parte dos mapas elaborados pelo Instituto Agronômico de Campinas (IAC) na escala 1: 100.000 está disponível neste banco de dados. 
O projeto Banco de Dados Geomorfométricos do Brasil (TOPODATA) oferece livre acesso a variáveis geomorfológicas derivadas de dados SRTM (resoluçáo espacial de aproximadamente $30 \mathrm{~m}$ ) para todo o território nacional. Com isso, os pesquisadores têm ganhos operacionais e, principalmente, de velocidade na análise de dados e produção científica (VALERIANO, 2008).

Segundo Valeriano (2008), o MDE é um arquivo que contém registros altimétricos estruturados em linhas e colunas georreferenciadas, como uma imagem com um valor de elevação em cada pixel. Os registros altimétricos devem ser valores de altitude do relevo, idealmente, para que o MDE seja uma representaçáo da topografia.

O MDE para todo território nacional está disponível para download no site do TOPODATA em: http://www.webmapit.com.br/inpe/topodata. Ao abrir o site, verifica-se que os dados estão estruturados em quadrículas compatíveis com a escala 1:250.000. A obtenção dos dados deve ser feita a partir da seleção da folha de interesse. Após essa seleção, aparecerá uma janela, e a opção "Altitude" deve ser escolhida. Imediatamente, iniciará o download de um arquivo .zip.

Após descompactado, constata-se que o mesmo se encontra em formato GeoTIFF. Já em ambiente de SIG, deve-se atribuir um sistema geodésico de referência, e, neste caso, utiliza-se o Datum WGS 84, seguido do SIRGAS2000. A partir do MDE, é possível extrair as curvas de nível, gerar o mapa hipsométrico, a carta de declividades, entre outros, em escala 1: 50.000 .

Neste caso, o MDE foi gerado a partir de dados SRTM (Shuttle Radar Topographic Mission), disponibilizados gratuitamente pelo United States Geological Survey (USGS). Tais dados foram refinados da resolução espacial original de, aproximadamente, $90 \mathrm{~m}$ para $30 \mathrm{~m}$ por krigagem. Também foram corrigidas imperfeiçôes como "buracos" na imagem.

O MDE do estado de São Paulo está disponível para download em formato TIF em: http://www.ambiente.sp.gov.br/cpla/modelo-digital-de-elevacao-mde-do-estado-de-sao-paulo/n. O mesmo foi gerado a partir das curvas de nível em escala 1: 50.000, extraídas das cartas do IBGE, do Instituto Geográfico e Geológico (IGG) e do Departamento de Serviços Geográficos do Exército, com resolução horizontal de 30m (0,0002777 graus decimais). Os arquivos estão em coordenadas geográficas (lat/long), Datum SIRGAS2000 (SÃO PAULO. SMA, 2013c). 
Dentre os produtos disponibilizados no TOPODATA, estão as classes de declividade, relevo sombreado, orientaçáo e forma das vertentes, acessíveis através do endereço: http://www.webmapit.com.br/inpe/topodata. Nele, o território brasileiro está dividido em quadrículas na escala 1:250.000. Ao selecionar a quadrícula desejada, surgirá uma janela com uma lista de arquivos disponíveis para download. Neste caso, deve-se optar pela "Forma de Terreno". Depois de descompactados, verifica-se que os arquivos matriciais possuem formato GeoTIFF. No SIG adotado deve ser atribuído o sistema de referência espacial WGS 84, uma vez que os dados estão em coordenadas geográficas (lat/long). Posteriormente, os mesmos devem ser convertidos para o Datum SIRGAS2000.

Após adicionar os arquivos GeoTIFF à lista do ArcGIS, recomendase fazer o download das paletas não lineares (arquivos em extensão .lyr), pois são cruciais para a observação apropriada dos dados. Conforme ressaltado por Valeriano (2008), o uso apropriado destes produtos requer o conhecimento de aspectos prévios à sua obtenção, como as características dos dados e suas relaçóes com propriedades do terreno, além dos conceitos e métodos envolvidos nas derivaçôes e formas adequadas de representação, informaçóes que podem ser obtidas no "Guia de Utilização do TOPODATA”, disponível em: http://mtc-m18.sid.inpe.br/col/sid.inpe.br/mtc-m18@80/2008/07.11.19.24/doc/publicacao.pdf.

Nas últimas décadas, com o crescimento da aplicação das ferramentas de geotecnologia, imagens de satélite e outros produtos geográficos tornaram-se mais facilmente acessíveis. Deste modo, diversos segmentos da sociedade passaram a utilizar imagens de satélite para diversas finalidades, como, por exemplo, as imagens disponibilizadas pelo Google Earth.

Nos estudos ambientais, os de mapas de uso e ocupaçáo do solo são geralmente elaborados a partir de imagens de média resolução espacial, disponibilizadas por órgãos governamentais, como o USGS, o Instituto Nacional de Pesquisas Espaciais (INPE) e outros.

A melhor opção para pesquisa e obtenção de imagens Landsat é o site http://earthexplorer.usgs.gov (USGS, 2015). Para poder acessar o banco de dados desse órgão, deve-se fazer um cadastro. Após o cadastro, deve-se selecionar a área de interesse das seguintes formas: diretamente na tela, por meio de órbita/ponto ou através de um arquivo .shp ou .kml. Ressaltase que são aceitos arquivos com um máximo de 30 pontos; neste caso, é aconselhado recortar a área de estudo com somente quatro pontos. Devese também atentar para as datas das imagens disponíveis. 
Posteriormente, são apresentadas as opçôes de imagens na aba "Data Sets", na qual se deve selecionar a opção "Landsat Archive" e depois "Results". Para visualizar as cenas, uma opção é clicar em "Show Browse Overlay" que mostra instantaneamente a imagem sobreposta ao mapa. Se a imagem satisfizer as necessidades do usuário, deve-se clicar em "Download Option”. Na próxima janela, seleciona-se o conjunto de imagens brutas no formato GeoTIFF. Após o download, os arquivos de imagens devem ser descompactados para a pasta de trabalho no SIG utilizado.

\section{Aquisição de dados censitários}

A seguir são apresentados exemplos de como coletar dados censitários. Dados históricos, como os disponibilizados pelo IBGE sobre a população e suas projeçôes, bem como dados do consumo de água para abastecimento industrial e humano (rural e urbano) são imprescindíveis para a quanti-qualificação dos processos hidrológicos (PORTO; AZEVEDO, 1997). No entanto, a aquisição de dados censitários para os estudos em bacias hidrográficas apresenta alguns inconvenientes técnicos, como o fato dos mesmos serem disponibilizados por municípios cujos limites não coincidem com aqueles das sub-bacias. Isso dificulta a sobreposição espacial das informaçôes e a análise integrada dos meios físico, biológico, antrópico e socioeconômico.

Outra dificuldade é a interpretação e manipulação no SIG dos dados disponibilizados pelo IBGE, uma vez que estes, muitas vezes, aparecem nas planilhas na forma de códigos. Em função disso, são escassos os trabalhos que correlacionam informaçóes demográficas e socioeconômicas com dados ambientais na escala de sub-bacia.

Para a aquisiçáo de dados oriundos do censo demográfico a serem analisados em ambiente SIG, deve-se acessar o site do IBGE em http:// www.ibge.gov.br/home, navegar até a aba "Download" e acessar a opção "Geociências". Abrir-se-á, portanto, uma árvore de pastas, dentre as quais deve-se optar por "malhas_digitais", seguida por "censo_2010" e, finalmente, por "setores_censitários". Verifica-se, nesta última que os dados estáo compactados e separados por Unidades da Federaçáo.

Para exemplificar tais procedimentos e como manipulá-los em ambiente SIG, serão utilizados os dados do estado de São Paulo. Ao escolher essa opção, inicia-se o download que deve ser salvo numa subpasta, de preferência intitulada "censo", dentro da pasta de trabalho do SIG. No caso 
do ArcGIS, verifica-se que o arquivo baixado possui os limites dos municípios (35MUE250GC_SIR) e todas a subdivisóes dos setores censitários (35SEE250GC_SIR).

Para ter acesso aos dados brutos do censo na forma de planilhas, é necessário navegar até a aba "Estatísticas" e selecionar a opção "Censos", seguida de "Censo_Demográfico_2010", "Resultados_do_Universo" e, finalmente, "Agregados_por_Setores_Censitários”. Nesta pasta, está disponível em "Documentacao_Agregado_dos_Setores_2010_20150527.zip" o memorial descritivo "Base de informaçōes do Censo Demográfico 2010: Resultados do Universo por setor censitário”, com informaçôes dos arquivos e possíveis códigos encontrados nas planilhas (IBGE, 2011). Logo, aconselha-se o estudo prévio deste documento. Ressalta-se que na pasta "Agregados_por_Setores_Censitários", os dados estão separados por Unidades da Federação. No caso do estado de São Paulo, tem-se informaçóes da capital e do restante do estado.

Dando continuidade ao exemplo do estado de São Paulo, ao ser realizado o download do arquivo "SP_Exceto_Capital", verifica-se que os arquivos estáo disponíveis na forma de planilhas e no formato CSV ou EXCEL. Como exemplo, ao abrir a planilha "Basico_SP2.xls", ressalta-se que existem várias informaçóes e que os nomes estão codificados. Neste ponto, deve-se acessar o arquivo de documentação para que seja verificado o significado de cada código que intitula as colunas.

No ArcGIS, deve-se extrair ou recortar as informações referentes à bacia hidrográfica estudada do arquivo que contém os setores censitários, no caso: "35SEE250GC_SIR". Porém, neste arquivo, ainda náo consta nenhuma informação referente aos dados censitários, pois estes estão na forma de planilha no arquivo "SP_Exceto_Capital".

Para adaptar e integrar as informaçôes referentes aos setores censitários (35SEE250GC_SIR) com o banco de dados na forma de planilha (SP_Exceto_Capital), é necessário efetuar alguns procedimentos no aplicativo ArcCatalog do ArcGIS, como se segue: clicando duas vezes sobre "Basico_SP2.xls" será aberto outro arquivo, clicando sobre ele com o botão direito do mouse, é possível exportar essa informação no formato dBASE (.dbf) para a subpasta "censo", criada anteriormente. Neste caso, na janela "Table to Table" do ArcCatalog, atribui-se um novo nome para a planilha a ser exportada. Na caixa "Field map", deve-se clicar com o botáo direito sobre "Cod_setor", escolhendo-se a opçáo "Propriedades". Na janela "Output 
Field Properties," deve ser alterado, na caixa "Tipo", o formato "Double" para "Text", com tamanho de 20 caracteres.

Novamente, no ArcGIS, deve-se abrir o arquivo da bacia hidrográfica, que contém os dados dos setores censitários recortados anteriormente do arquivo "35SEE250GC_SIR". Ao clicar sobre o arquivo com o botão direito, navegue até a opção "Joins and Relates" e em seguida escolha "Join". $\mathrm{Na}$ janela que será aberta, apareceráo algumas opçóes: na caixa "What do you want to join to this layer?", escolha "Join attributes from a table". Na caixa 1, escolha "CD_GEOCODI”; na caixa 2, deve-se navegar até a subpasta "censo" e selecionar a planilha no formato dBASE (.dbf) criada anteriormente e a caixa 3 será preenchida automaticamente.

Deste modo, os dados censitários estarão prontos para serem analisados no ArcGIS. Por exemplo, o número de moradores na área de uma bacia hidrográfica pode ser utilizado para calcular densidade demográfica. Vale ressaltar que o mesmo procedimento de aquisição de dados pode ser utilizado para a obtenção de outras informaçôes censitárias, como, por exemplo, renda e escolaridade. 


\section{Referências}

ALMEIDA, C. N. et al. Novas Tecnologias de Informaçóes em Recursos Hídricos. Revista Brasileira de Recursos Hídricos, Porto Alegre, v. 14, n. 2, p. 107-116, 2009.

CÂMARA, G.; DAVIS, C.; MONTEIRO, A. M. V. Introduçáo à ciência da geoinformaçáo. São José dos Campos, SP: INPE-10506-R$\mathrm{PQ} / 249,2001$.

CAMP, M. van; WALRAEVENS, K. Recovery scenarios for deep over-exploited aquifers with limited recharge: methodology and application to an aquifer in Belgium. Environmental Geology, v. 56, p. 1505-1516, 2008.

CARVAlHO, M. V. A.; DI MAIO, A. C. Proposta para a difusão de dados e informaçóes geoespaciais disponíveis gratuitamente na Internet junto aos graduandos e professores da educação básica. In: SIMPÓSIO BRASILEIRO DE SENSORIAMENTO REMOTO, 15. (SBSR), 2009, Curitiba. Anais... São José dos Campos: INPE, 2011. p. 3351-3358.

CHEN, M.; WEN, Y.; YUE, S. A progressive transmission strategy for GIS vector data under the precondition of pixel losslessness. Arabian Journal of Geosciences, v. 1, n. 13, p. 3461-3475, 2014.

CULSHAW, M. G.; JACKSON, I.; GILES, J. R. A. The provision of digital spatial data for engineering geologists. Bulletin of Engineering Geology and the Environment, v. 65, n. 2, p. 185-194, 2006.

EASTMAN, J. R. Idrisi for Windows-user's guide. Version 1.0. Worchester, Massachusetts: Clarks Labs for Cartographic Technology and Geographic Analysis, Clarks University, 1995.

ENVIRONMENTAL SYSTEMS RESEARCH INSTITUTE - ESRI. ArcGIS Professional GIS for the desktop. Versão 10.2. ESRI, 2013.

FLORENZANO, T. G. Geotecnologias na geografia aplicada: difusão e acesso. Revista do Departamento de Geografia, São Paulo, v. 17, p. 2429, 2005. 
FOOD AND AGRICULTURE ORGANIZATION OF THE UNITED NATIONS - FAO. The state of the world's land and water resources for food and agriculture. Managing systems at risk. Rome and Earthscan, London: Food and Agriculture Organization of the United Nations, 2011.

GOOGLE. Keyhole markup language. Disponível em: <https://developers.google.com/kml/?hl=pt-br>. Acesso em: 13 jul. 2015.

INTERNATIONAL ENERGY AGENCY - IEA. World energy outlook 2012. Paris: OECD/IEA, 2012. Disponível em: <http://www. worldenergyoutlook.org>. Acesso em: 23 jul. 2015.

INSTITUTO BRASILEIRO DE GEOGRAFIA E ESTATÍSTICA IBGE. Base de informaçóes do censo demográfico 2010: resultados do universo por setor censitário. Rio de Janeiro: Ministério de Planejamento, Orçamento e Gestão, Centro de Documentação e Disseminação de Informaçôes, 2011.

INSTITUTO BRASILEIRO DE GEOGRAFIA E ESTATÍSTICA IBGE. Resoluçáo 01, de 25 de fevereiro de 2005. Altera a caracterização do Sistema Geodésico brasileiro. Disponível em: <http://www.ibge. gov.br/home/geociencias/geodesia/pmrg/leg.shtm>. Acesso em: 23 set. 2015.

INSTITUTO BRASILEIRO DE GEOGRAFIA E ESTATÍSTICA IBGE. Resoluçáo 01, de 24 de fevereiro de 2015. Define a data de término do período de transição definido na RPR 01/2005 e dá outras providências sobre a transformação entre os referenciais geodésicos adotados no Brasil. Disponível em: <http://www.ibge.gov.br/home/geociencias/ default_normas.shtm?c=14>. Acesso em: 23 set. 2015.

INSTITUTO BRASILEIRO DE GEOGRAFIA E ESTATÍSTICA - IBGE. Vetorização de cartas topográficas. Especificaçóes técnicas. 2014. Disponível em: <http://www.ibge.gov.br/home/geociencias/cartografia/vetori.shtm>. Acesso em: 24 mai. 2015.

INSTITUTO NACIONAL DE COLONIZAÇÃO E REFORMA AGRÁRIA - INCRA. Certificação de imóveis rurais.2015. Disponível em: <http://www.incra.gov.br/certifica-imoveis-rurais-sigef>. Acesso em: 12 jul. 2015. 
JANSEN, J. R. Sensoriamento remoto do ambiente: uma perspectiva em recursos terrestres. Sáo José dos Campos, SP: INPE, 2009.

MALCZEWSKI, J. GIS-based land-use suitability analysis: a critical overview. Progress in Planning, v. 62, n. 1, p. 3-65, 2004.

McKINNEY D. C. et al. Modeling water resources management at the basin level: review and future directions. SWIM Paper 6. Colombo, Sri Lanka: International Water Management Institute, 1999.

MEDEIROS, J. S.; CÂMARA, G. Geoprocessamento em projetos ambientais. São José dos Campos, SP: INPE-8568-PRE/4312, 2001.

MILLENNIUM ECOSYSTEM ASSESSMENT. Ecosystems and human well-being: synthesis. Washington, DC: Island Press, 2005.

MINISTÉRIO DO MEIO AMBIENTE - MMA. Software i3Geo. 2015 Disponível em: <http://mapas.mma.gov.br/i3geo/mma/openlayers. htm?855m1oii56mm70irt37p0f9s91>. Acesso em: 13 set. 2015.

OPEN GEOSPATIAL CONSORTIUM - OGC. Glossary of terms. 2015 Disponível em: <http://www.opengeospatial.org/ogc/glossary>. Acesso em: 21 mai. 2015.

PORTO, R. L. L; AZEVEDO, L. G. T. Sistemas de suporte a decisóes aplicados a problemas de recursos hídricos. In: PORTO, R. L. L. (Org.) Técnicas quantitativas para o gerenciamento de recursos hídricos. Porto Alegre: UFRGS/ABRH, 1997. p. 42-95.

RAVENGA, C. Developing indicators of ecosystem condition using geographic information systems and remote sensing. Regional Environmental Change, v. 5, n. 4, p. 205-214, 2005.

RITTER, N.; RUTH, M. The GeoTiff data interchange standard for raster geographic images. International Journal of Remote Sensing, v. 18, n. 7, p. 1637-1647, 1997.

ROEHRIG, J. Information interoperability for river basin management. Technology Resource Management \& Development, v. 2, p. 141-148, 2002. 
SÃO PAULO. SECRETARIA DO MEIO AMBIENTE - SMA. Rede de drenagem do Estado de Sáo Paulo obtida a partir da base do GISAT (cartas topográficas na escala 1:50.000) por processo automático. São Paulo: CPLA/SMA, 2013 a.

SÃO PAULO. SECRETARIA DO MEIO AMBIENTE - SMA. Sub-bacias hidrográficas do Estado de São Paulo. São Paulo: CPLA/SMA, 2013b.

SÃO PAULO. SECRETARIA DO MEIO AMBIENTE - SMA. Modelo Digital de Elevação (MDE) do estado de São Paulo obtido a partir da base do GISAT (cartas topográficas na escala 1:50.000). São Paulo: CPLA/SMA, 2013c.

SELVARADJOU, S. K. et al. European Digital Archive of Soil Maps. Soil Maps of Latin America and Caribbean Islands. 2005. Disponível em: $<$ http://www.eusoils.jrc.ec.europa.eu/esdb_archive/eudasm/latinamerica/ lists/cbr.htm>. Acesso em: 15 set. 2015.

SIQUEIRA, C. A. Arquivos digitais gráficos: a escolha entre diversos formatos existentes na computação gráfica. Cadernos da Escola de Comunicaçáo, Curitiba v. 1, n. 6, p.1-8, 2008.

TUCCI, C. E. M.; MENDES, C. A. Avaliaçáo ambiental integrada de bacia hidrográfica. Brasília, DF: Ministério do Meio Ambiente, 2006.

UNITED NATIONS WORLD WATER ASSESSMENT PROGRAMME - WWAP. The United Nations World Water Development Report 2015: water for a sustainable world. Paris: UNESCO, 2015.

UNITED STATES GEOLOGICAL SURVEY - USGS. Earth explorer. 2015. Disponível em: <http://earthexplorer.usgs.gov>. Acesso em: 14 jul. 2015.

VALERIANO, M. M. TOPODATA: guia para utilização de dados geomorfológicos locais. São José dos Campos, SP: INPE-15318-RPQ/818, 2008.

VINHAS, L. Um subsistema extensível para o armazenamento de geocampos em banco de dados geográficos. 2006. $112 \mathrm{f}$. Tese (Doutorado) - Instituto Nacional de Pesquisas Espaciais, São José dos Campos, SP, 2006. 


\section{Bacia do rio Almada (Bahia): criaçáo de cenários ambientais a partir do diagnóstico da fragmentação florestal}

Waleska Ribeiro Caldas da Costa Viana

Maria Eugênia Bruck de Moraes

\section{Introduçáo}

Bacias hidrográficas são sistemas ecológicos complexos em função do conjunto de interaçóes antrópicas e naturais que ocorrem em seus limites. As comunidades humanas têm se estabelecido nas proximidades dos corpos d'água desde os primórdios da história e a sua atuação, desde então, tem ocasionado fenômenos danosos aos biomas, ecossistemas e comunidades inseridos em seu território.

Tradicionalmente, a necessidade de uso e ocupação do solo tem precedido os estudos sobre seus sistemas naturais, haja vista a necessidade de se ocupar espaços naturais, modificando suas estruturas, para extrair deles matéria prima e energia para a produçáo de bens de consumo, alimento e para a geraçáo de renda. Tal necessidade acarreta muitos danos ambientais, alguns passíveis de recuperaçáo e outros irreparáveis. Nessa perspectiva, o desenvolvimento de atividades antrópicas que respeitem a sustentabilidade e a manutenção dos serviços ecossistêmicos em uma bacia hidrográfica é fundamental.

Pires, Santos e Del Prette (2002) destacam que o conceito de bacia hidrográfica tem sido ampliado e expandido, passando a ser utilizado na área de planejamento ambiental como unidade de gestão da paisagem, envolvendo o conhecimento da estrutura biofísica da bacia e a dinâmica nos padróes de uso e ocupação do solo. Steinitz et al. (1991) ressaltam que a abordagem metodológica para subsidiar as atividades de gestão ambiental em uma bacia deve contemplar os conceitos e métricas da Ecologia da Paisagem. 
Segundo Forman e Godron (1986), o estudo da paisagem deve considerar três características principais: sua estrutura, formada por uma matriz (elemento predominante), manchas e corredores; sua função, relacionada à interação entre os elementos que a compóem; e sua dinâmica, as alteraçóes na estrutura e função ao longo do tempo.

Para Forman (1995), a análise da estrutura da paisagem representa uma etapa essencial para o seu manejo, considerando a sua integridade ecológica e o desenvolvimento de atividades antrópicas na perspectiva da sustentabilidade e manutenção dos serviços ecossistêmicos.

A dinâmica, consequência em parte da ação do homem e técnicas por ele empregadas, reflete na inter-relação dos componentes bióticos e abióticos dos ecossistemas ali existentes. Esta dinâmica, por sua vez, pode gerar uma heterogeneidade na paisagem, com formação de manchas de diferentes tamanhos (LANG; BLASCHKE, 2009). Esse processo é denominado fragmentação, sendo atualmente uma das principais consequências da atividade antrópica.

$\mathrm{Na}$ medida em que altera os processos ecológicos, a fragmentação florestal em uma dada paisagem desequilibra a própria estrutura e funcionamento do cenário biótico, provocando não só grande suscetibilidade dos fragmentos a distúrbios externos, mas até extinção de espécies nativas (caso o processo de fragmentação não seja devidamente freado). Daí a importância da avaliação da fragmentação florestal a partir do emprego de métricas da paisagem (FORMAN, 1995; METZGER, 1999; PIRES; PIRES; SANTOS, 2004; MORAES et al., 2012).

Existe uma diversidade de métricas da paisagem que pode contribuir para o entendimento dos processos que geram a fragmentaçáo florestal. $\mathrm{O}$ estudo do arranjo espacial dos fragmentos em uma paisagem pode empregar o uso de métricas como o número, tamanho, formato, isolamento e simulaçóes de conectividade dos fragmentos, dentre outras.

De acordo com Pires, Pires e Santos (2004), a restauração da conectividade entre fragmentos é de suma importância para a manutenção da diversidade biológica e da integridade dos ecossistemas inseridos em uma paisagem. Os autores ainda destacam que a definiçáo de alternativas de manejo para uma bacia hidrográfica pode ser beneficiada pela criação de cenários ambientais voltados para a conservaçáo dos recursos naturais e manutenção das funções ecológicas. Forman (1995) destaca que a identificação de alternativas para reestabelecer a conectividade entre os compo- 
nentes de uma paisagem é de fundamental importância para o seu manejo adequado.

Em função de sua localização, área de abrangência, propriedades físico-bióticas, características socioeconômicas e uso da água para o abastecimento público, a bacia do rio Almada apresenta uma série de conflitos ambientais que são agravados pela expansão das atividades agropecuárias e turísticas (SANTANA, 2011).

Quanto aos usos da água, os mananciais desta bacia, em especial o rio Almada, são utilizados para o abastecimento público de quase todas as cidades e povoados da Regiáo Cacaueira no Sul da Bahia, inclusive do município de Itabuna, que também faz parte da bacia do rio Cachoeira (BAHIA, 2001).

Dados preliminares apontam que o fenômeno de fragmentação florestal associado ao crescimento da atividade pecuária tem se intensificado na bacia do rio Almada (VIANA, 2011; MORAES et al., 2012), fato este que influenciou na escolha desta bacia para a realização de estudos mais aprofundados. Nesse sentido, o presente capítulo apresenta um estudo sobre a avaliação da fragmentação florestal e criação de cenários ambientais para esta bacia a partir da delimitação de três unidades de gerenciamento.

\section{Caracterização da bacia do rio Almada}

A Bacia Hidrográfica do Rio Almada (BHRA) abrange uma área em torno de $1.570 \mathrm{~km}^{2}$ e está inserida, total ou parcialmente, nos municípios de Almadina, Coaraci, Ibicaraí, Barro Preto, Itajuípe, Itabuna, Ilhéus e Uruçuca, todos abastecidos completamente ou em parte pelas águas desta bacia (Figura 1).

O clima, segundo a classificação de Köppen, é definido como do tipo Tropical Chuvoso Selva Isotérmico (Afi), com índices pluviométricos de médias anuais de $1.780 \mathrm{~mm}$, diminuindo gradativamente para o interior. A maior incidência de chuvas ocorre no período de março a abril. Ainda, a temperatura anual apresenta média de $22,9^{\circ} \mathrm{C}$, com valores mínimos em julho e agosto e máximos em janeiro e fevereiro. Já a umidade relativa é máxima nos meses de maio, junho e julho, coincidindo com os períodos de baixas temperaturas e baixo número de horas de insolação (BAHIA, 2001). 


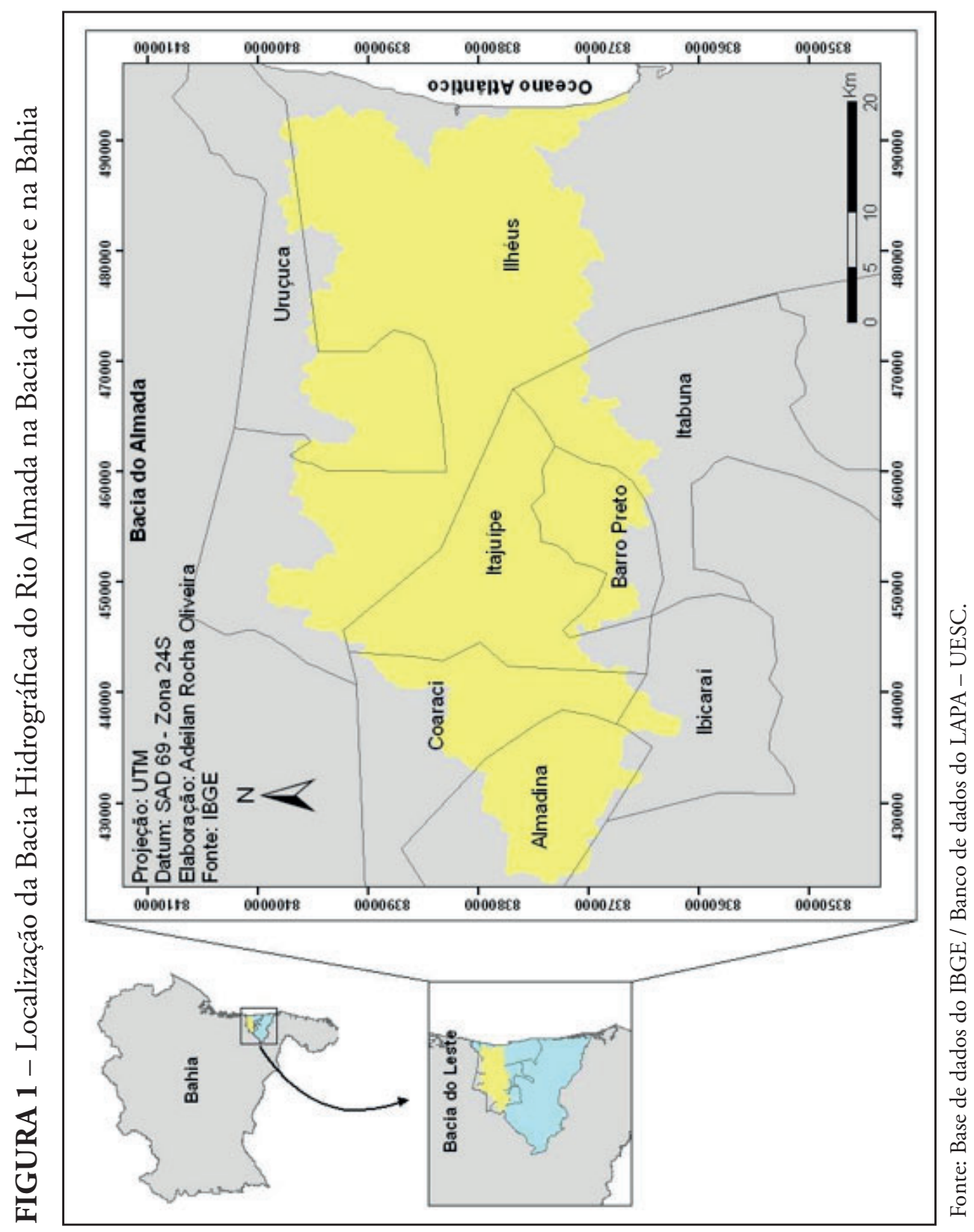

Devido à estruturação do substrato rochoso, a rede de drenagem que compóe a bacia - com densidade de drenagem em torno de $1,56 \mathrm{~km} / \mathrm{km}^{3}$, diferencia-se em, pelo menos, dois setores. Na porção oeste, ocorre o predomínio do padrão em treliça; e no restante da bacia, ocorre, preferencialmente, o padrão dendrítico. $\mathrm{O}$ rio Almada possui $138 \mathrm{~km}$ de extensão, nascendo no município de Almadina e desaguando no Oceano Atlântico, 
em Ilhéus. Seus principais afluentes da margem direita são o rio do Braço, o ribeirão do Boqueirão e o riacho Sete Voltas; enquanto, na margem esquerda, encontram-se o rio São José e os ribeiróes de Jussara e Braço Norte (MORAES et al., 2012).

De acordo com Gomes et al. (2012), as cotas altimétricas distribuemse entre 0 e $370 \mathrm{~m}$, com acentuado desnível entre a baixada litorânea (0 a $80 \mathrm{~m})$ e as serras do Pereira e do Chuchu (180 a $370 \mathrm{~m})$, localizadas na porção oeste da bacia. Já nos topos de morro, a altitude chega a atingir $1.050 \mathrm{~m}$.

A bacia é geologicamente integrante da unidade geotectônica Cráton do São Francisco e pertence ao domínio geotectônico/geocronológico Escudo Oriental da Bahia e, em menor extensão, à Província Costeira e Margem Continental. O primeiro corresponde aos limites do Cráton do São Francisco, de idade pré-cambriana, enquanto a segunda é constituída pelas bacias costeiras mesocenozóicas, representadas pela Bacia Sedimentar do rio Almada (GOMES et al., 2012).

De acordo com o Sistema Brasileiro de Classificação de Solos (EMBRAPA, 2006), as unidades de solo são: ARGISSOLO VERMELHO-AMARELO Distrófico, ARGISSOLO VERMELHO-AMARELO Eutrófico, ESPODOSSOLO FERROCÁRBICO Hidromórfico, LATOSSOLO AMARELO Coeso, ARGISSOLO AMARELO Distrófico, LUVISSOLO CRÔMICO Órtico e NEOSSOLO QUARTZARÊNICO (FRANCO et al, 2012; GOMES, 2013).

Quanto ao uso e ocupação do solo, as principais classes são: as áreas urbanas, pastagens e áreas de solo exposto, que juntas correspondem a 23\% da área da bacia; as áreas de cabruca, com 54\%; e os remanescentes de Mata Atlântica (Floresta Ombrófila Densa e Floresta Estacional Semidecidual) e ecossistemas associados (restinga e manguezal), que correspondem a 18\% (MORAES et al., 2012; GOMES et al., 2013).

A cabruca é o sistema agroflorestal adotado na BHRA para o cultivo do cacau (Theobroma cacao L.) à sombra das copas das árvores da floresta nativa (SAMBUICHI et al., 2012). Esse sistema é considerado muito superior em termos de conservaçáo da biodiversidade, quando comparado com outras monoculturas ou pastagens (SCHROTH et al., 2011). 


\section{Métodos e Técnicas de Pesquisa}

\section{Delimitação das unidades de gerenciamento}

Foram delimitadas automaticamente 30 sub-bacias hidrográficas por meio da interface ArcSWAT no Sistema de Informação Geográfica (SIG) ArcGIS 9.3. Posteriormente, foram unidas as sub-bacias que apresentaram características físico-ambientais similares como características climáticas, curvas de nível, hidrografia e uso do solo. Tais atributos contribuem para um funcionamento diferenciado em cada Unidade de Gerenciamento (UG). Por fim, foram delimitadas três unidades de gerenciamento que representam o alto, médio e baixo curso do rio Almada e seus respectivos afluentes (Figura 2).

\section{Mapeamento dos fragmentos florestais}

Para o mapeamento dos fragmentos florestais foi utilizada a Carta de Uso e Ocupação do Solo da BHRA em escala 1:100.000, disponibilizada pelo Laboratório de Análise e Planejamento Ambiental (LAPA) da Universidade Estadual de Santa Cruz (UESC).

Foram vetorizados os polígonos correspondentes aos fragmentos florestais das três unidades de gerenciamento através do ArcMAP 9.3. Esses polígonos foram classificados por tamanho, totalizando sete classes, que variaram de menos de 5 ha até mais de 100 ha.

\section{Métricas da paisagem aplicadas}

Após o cálculo do tamanho dos fragmentos, partiu-se para a avaliação do formato dos fragmentos, utilizando o Índice de Circularidade (IC). Esse índice avalia o formato dos fragmentos em relação à área de um círculo de mesmo tamanho através da fórmula

$$
I C=\frac{\sqrt{ } A 1}{A 2}
$$

em que: A1 é igual à área do fragmento em quilômetros quadrados e A2 equivale à área de um círculo de mesmo perímetro do fragmento correspondente. 


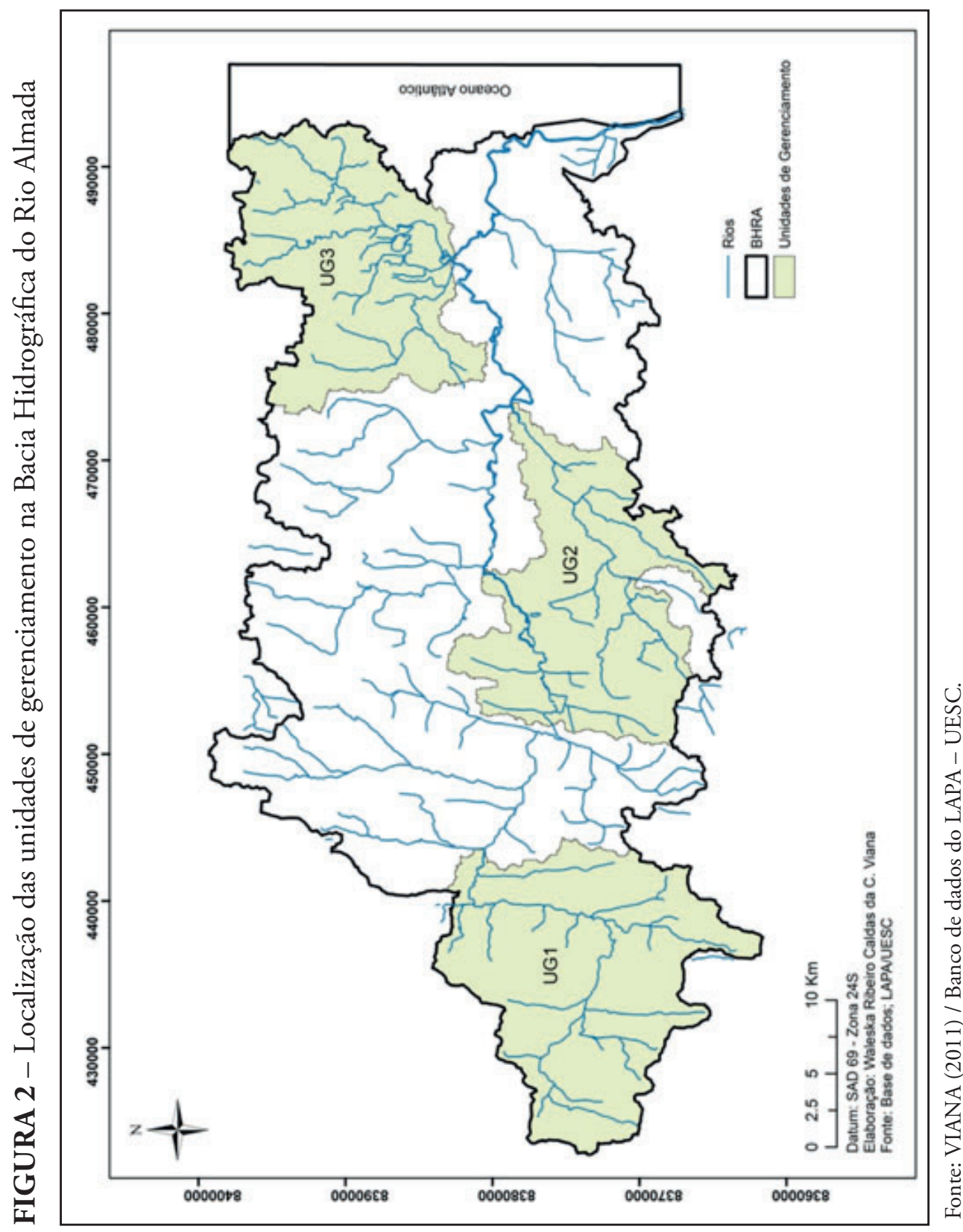

O grau de suscetibilidade dos fragmentos foi avaliado visando identificar a suscetibilidade de cada fragmento ao efeito de borda com base no IC, pois as áreas de borda de um fragmento são mais suscetíveis a efeitos negativos, tais como mudanças microclimáticas, fogo, aumento da atividade de indivíduos predadores e invasão de espécies exóticas (FOREROMEDINA; VIEIRA, 2007). Quanto mais próximo de 1 for o IC, mais arredondado é o fragmento e menor sua suscetibilidade ao efeito de borda. 
O grau de isolamento foi avaliado através da expansão das áreas de borda dos fragmentos em distâncias previamente determinadas com base em Ranta et al. (1998). Os fragmentos foram considerados isolados quando, a uma distância $d$ (pré-determinada), não havia sobreposição de sua borda à de outro fragmento. Da mesma maneira, os fragmentos foram considerados conectados quando houve sobreposição de sua borda expandida em relação à borda expandida dos fragmentos vizinhos.

Com o objetivo de propor alternativas de manejo da paisagem na BHRA, foram simulados dois cenários ambientais (cenário 1 e cenário 2). A criação desses cenários para as UG considerou três situaçóes distintas: cenário 0 , que representa o diagnóstico da fragmentação florestal atual; cenário 1, que simulou a conexão entre fragmentos pequenos e próximos; e cenário 2, que simulou a criação de Fragmentos de Ligação (FL).

\section{Diagnóstico da fragmentaçáo florestal atual}

\section{Tamanho e distribuição espacial dos fragmentos florestais}

A área de um fragmento é uma das métricas mais importantes no estudo de uma paisagem. Não apenas porque ele é a base para o cálculo de outras métricas, mas porque, por si só, representa uma informação de grande valor (FORMAN; GODRON, 1986). Fragmentos muito pequenos, por exemplo, náo sáo capazes de abrigar uma série de espécies. Belovsky (1987) afirma que para abrigar populaçóes mínimas viáveis de muitas espécies, o limite inferior de tamanho de área deveria ser de 1.000 ha. Por outro lado, autores como Laurence e Bierregaard (1997) já consideram fragmentos com área a partir de 300 ha como de alto valor para a conservação da biodiversidade, enquanto fragmentos com área inferior a 3 ha são considerados de baixíssimo valor para a manutenção de muitas espécies da fauna devido à grande suscetibilidade a fatores externos. 


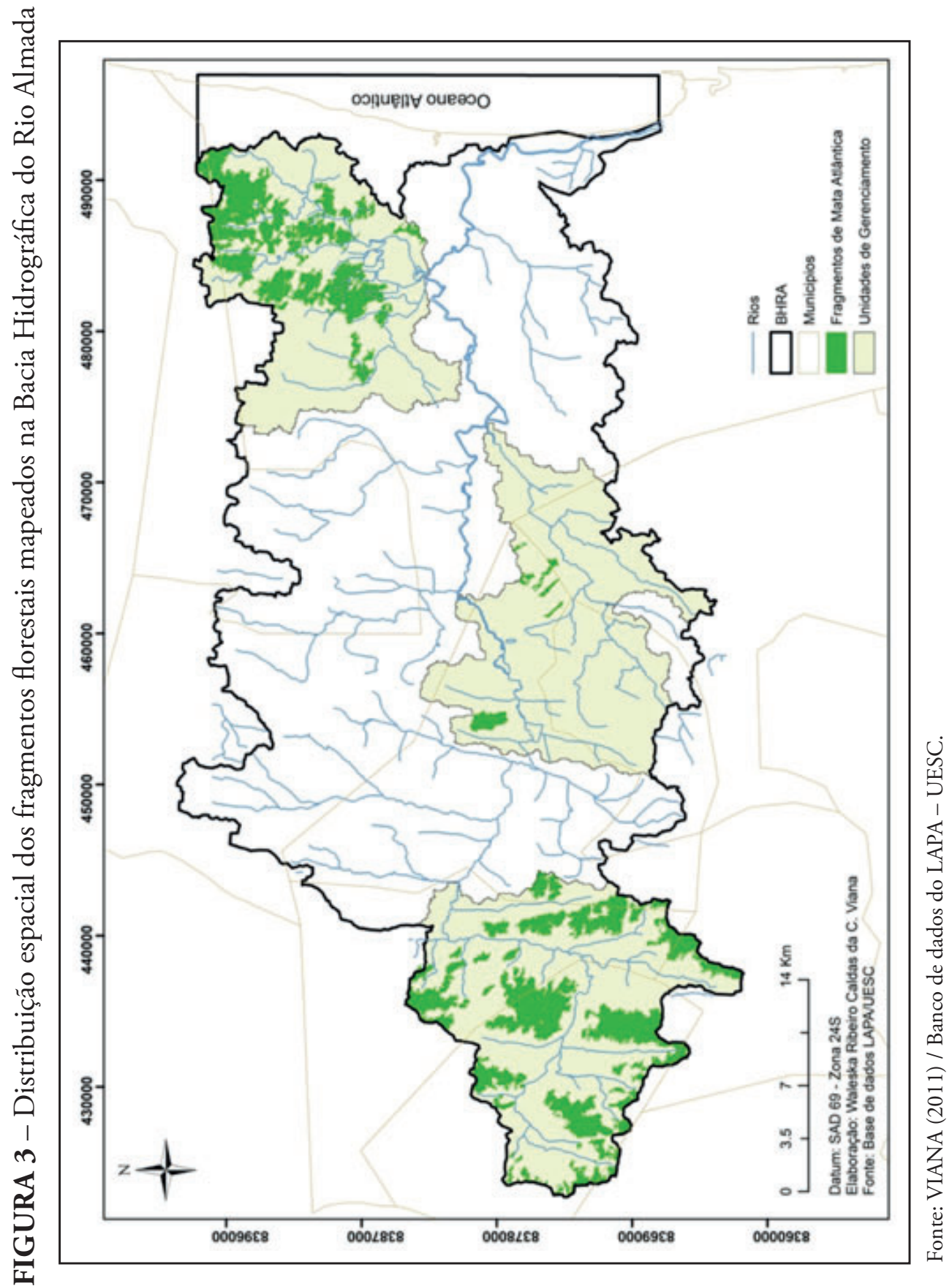

No presente estudo, foram mapeados 55 fragmentos florestais remanescente de Mata Atlântica, sendo que a maior parte está localizada na UG 1 (37 fragmentos), no interior da bacia, e na UG 3 (12 fragmentos), próxima ao litoral; enquanto na UG 2, porção central da bacia, foram 
identificados apenas 6 fragmentos (Figura 3). Como visto, a área de fragmentos pequenos é completamente afetada em termos microambientais, o que compromete especialmente a riqueza de espécies na borda. Uma vez que esses fragmentos tendem a desaparecer, optou-se por incluir três fragmentos com menos de 3 ha, que podem funcionar como trampolins ecológicos (stepping stones) entre fragmentos maiores (GUEVARA; PURATA; VAN DER MAAREL, 1986).

Assim, os fragmentos aqui mapeados e analisados variam entre menos de 3 ha e mais de 4.000 ha. Conforme apresentado na Tabela 1, dos 55 fragmentos, oito têm até 10 ha, 27 , até 100 ha, oito, até 250 ha e 12, mais de 250 ha. Tendo em vista o tamanho, pode-se considerar que a área de estudo ainda abriga fragmentos bastante representativos com significativo valor para a conservação da diversidade de espécies típicas da Mata Atlântica.

Por outro lado, a análise da Figura 4 revela uma má distribuição desses fragmentos, visto que na UG 2, além de identificados apenas seis fragmentos, cinco deles são pequenos (com menos de 25 ha) e alongados; e apenas um tem formato um pouco mais circular e possui mais de 50 ha. Deste modo, os fragmentos maiores estão limitados às porções leste (UG 3) e oeste (UG 1) da BHRA, sem conexão entre si. Moraes et al. (2012) encontraram situação semelhante e atribuem essa distribuição desigual ao aumento das áreas de pastagem na porção central da BHRA. Além disso, acrescentam que a manutençáo de fragmentos maiores e mais próximos uns dos outros, na porçáo leste da bacia, pode ter sido beneficiada pela dificuldade de acesso ao local.

TABELA 1 - Classes de tamanho dos fragmentos florestais (frags) mapeados

\begin{tabular}{l|crc}
\hline Classe de tamanho (ha) & $\mathbf{N}^{\circ}$ de frags & Área (ha) & Área relativa (\%) \\
\hline frags $<5$ & 4 & 11,93 & 0,09 \\
$5<$ frag $<10$ & 4 & 32,66 & 0,26 \\
$10<$ frag $<25$ & 6 & 115,35 & 0,90 \\
$25<$ frag $<50$ & 11 & 440,51 & 3,45 \\
$50<$ frag $<100$ & 10 & 680,82 & 5,33 \\
$100<$ frag $<250$ & 8 & $1.378,48$ & 10,80 \\
frags $>250$ & 12 & $10.102,44$ & 79,16 \\
\hline Total & $\mathbf{5 5}$ & $\mathbf{1 2 . 7 6 2 , 1 9}$ & $\mathbf{1 0 0 , 0 0}$ \\
\hline
\end{tabular}

Fonte: VIANA (2011). 


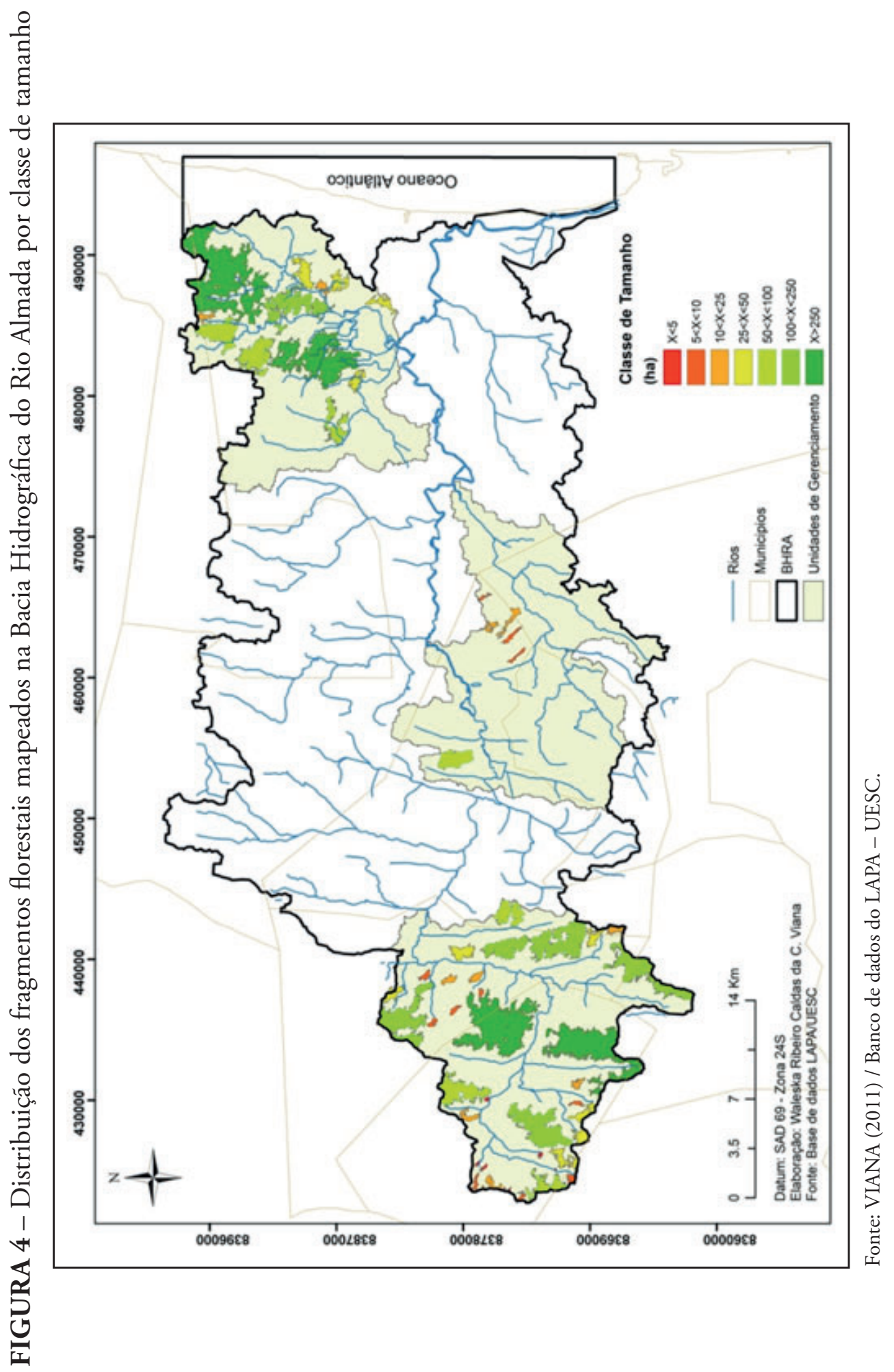


Quanto aos 37 fragmentos mapeados na UG 1, observa-se que muitos deles são pequenos (com até $25 \mathrm{ha}$ ), estando localizados na periferia da bacia. E os maiores encontram-se isolados uns dos outros.

\section{Formato dos fragmentos e suscetibilidade ao efeito de borda}

De acordo com Périco et al. (2005), o tamanho e o formato de um fragmento estão intrinsecamente ligados à borda e, quanto menor o fragmento ou mais alongado, mais intensos são os efeitos de borda em função da diminuição da razão interior/borda.

As espécies de interior, restritas às condiçóes ambientais das áreas internas dos fragmentos, são geralmente excluídas das bordas pelas espécies adaptadas a esse tipo de hábitat durante o processo de competiçáo. Desta forma, outro elemento relevante para a avaliação da fragmentação é a identificação do formato dos fragmentos.

No presente estudo, essa avaliação foi realizada através do cálculo do IC, visto que fragmentos com formato mais arredondado tendem a ter seu interior preservado dos efeitos de borda, mantendo as características microclimáticas inalteradas.

$\mathrm{Na}$ Figura 5, encontram-se os valores do IC de cada um dos fragmentos mapeados nas três unidades de gerenciamento. Observa-se que a maioria apresenta uma tendência ao formato alongado e que nenhum se aproximou do valor ideal; ou seja, IC $=1$. O IC mais próximo de 1 corresponde ao dos fragmentos 8 e 16, que apresentaram IC 0,6.

\section{Conectividade da paisagem e criação de cenários ambientais}

O processo de fragmentação de hábitats naturais é, em grande parte, resultado das atividades antrópicas que quebram a continuidade da paisagem, ocasionando mudanças tanto na estrutura e composição quanto na diversidade das comunidades locais. Esse processo acaba desencadeando outro grave fenômeno associado, o isolamento dos fragmentos, que reduz a quantidade de cruzamentos heterogênicos, diminuindo assim a variabilidade genética, causando extinçóes locais e, consequentemente, a perda de biodiversidade (METZGER, 1999). Em situaçóes dessa natureza, as populaçôes isoladas tendem a se tornar mais vulneráveis ao processo de extinção mediante a redução de recursos e a possibilidade de deterioração genética (HARRIS, 1984). 


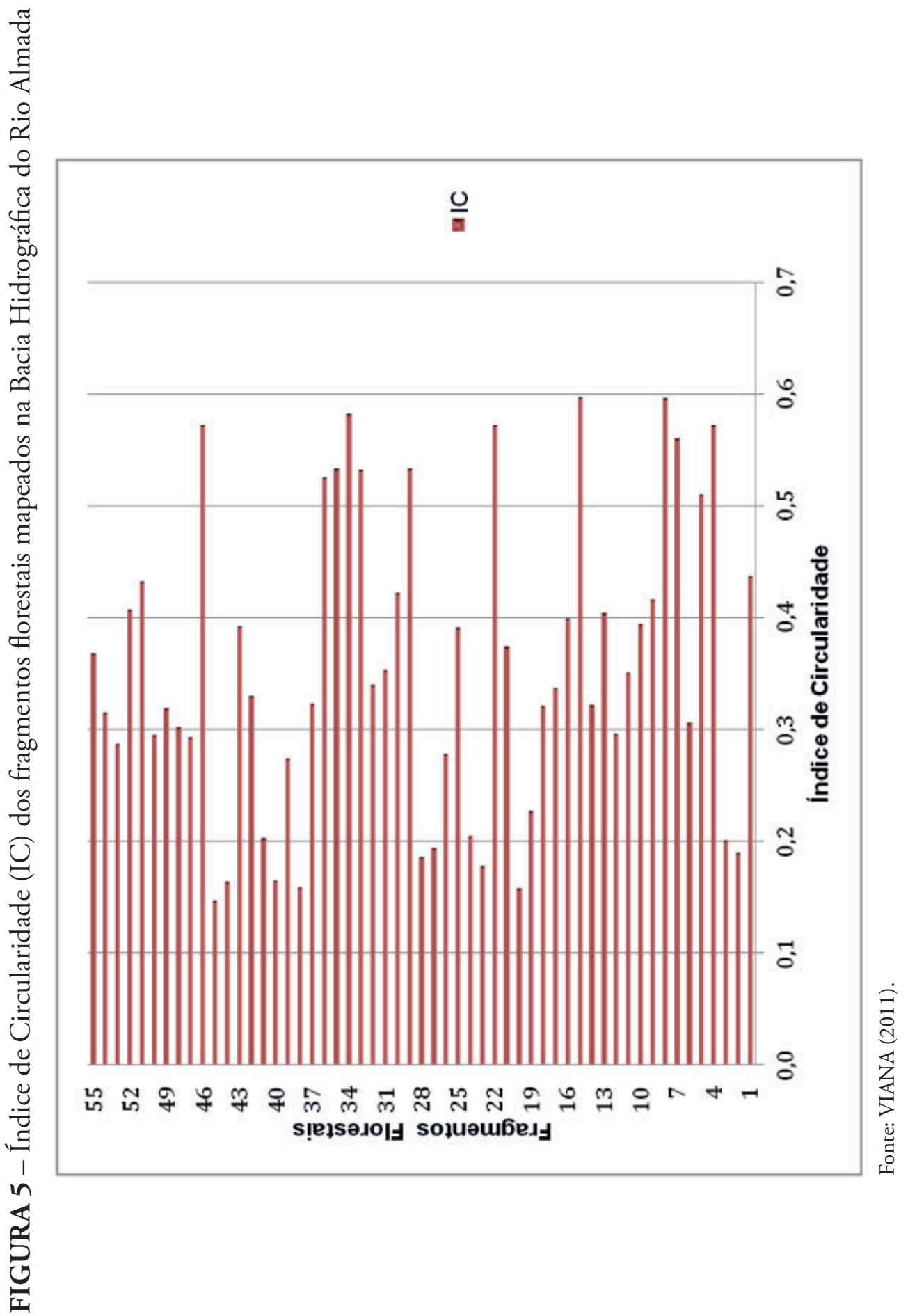


Quanto maior a distância entre os fragmentos, mais ocasional tornase o fluxo entre os mesmos, sendo que, em grandes distâncias (a partir de $350 \mathrm{~m}$ ), ele deixa de existir (PIRES; PIRES; SANTOS, 2004).

O fato dos fragmentos mapeados apresentarem no cenário atual (cenário 0) um formato alongado mostra que aqueles remanescentes de Mata Atlântica existentes na BHRA estáo ameaçados pelo efeito de borda. Isso justifica uma análise da conectividade a partir de simulaçóes da expansão da borda dos fragmentos. Esse tipo de análise simula atividades de reflorestamento, de processo natural de recuperação da área florestada ou de qualquer atividade desta natureza que amplie a área dos fragmentos florestais, possibilitando assim a conexáo entre eles e configurando uma opçáo para o planejamento da paisagem e das açóes de reflorestamento. Os resultados dessa análise estáo apresentados na Tabela 2.

TABELA 2 - Resultados da análise de conectividade entre fragmentos florestais (frags) identificados nas unidades de gerenciamento (UG) a partir da simulação da expansão de borda de 30 a $350 \mathrm{~m}$

\begin{tabular}{cccccc}
\hline & UG1 & UG2 & UG3 & \multicolumn{2}{c}{ Total } \\
\hline Borda $(\mathbf{m})$ & Frags $\left(\mathbf{n}^{\mathbf{o}}\right)$ & Frags $\left(\mathbf{n}^{\mathbf{o}}\right)$ & Frags $\left(\mathbf{n}^{\mathbf{o}}\right)$ & Frags $\left(\mathbf{n}^{\mathbf{o}}\right)$ & Frags $(\%)$ \\
\hline 30 & 5 & 0 & 9 & 14 & 25,5 \\
50 & 9 & 0 & 9 & 18 & 32,7 \\
100 & 23 & 0 & 10 & 33 & 60,0 \\
150 & 28 & 3 & 10 & 41 & 74,5 \\
200 & 33 & 3 & 10 & 46 & 83,6 \\
250 & 34 & 3 & 10 & 47 & 85,5 \\
300 & 35 & 3 & 11 & 49 & 89,1 \\
350 & 36 & 3 & 11 & 50 & 90,9 \\
\hline
\end{tabular}

Fonte: VIANA (2011).

A Tabela 2 mostra um gradiente crescente de conectividade entre os fragmentos, conforme aumenta-se o valor de expansão das bordas de 30 para $350 \mathrm{~m}$.

Na UG 1, composta por 37 fragmentos, a partir de uma expansão das bordas de $30 \mathrm{~m}$, cinco fragmentos passaram a se conectar; aumentando esse valor para $150 \mathrm{~m}, 28$ fragmentos conectaram-se; e com a expansão máxima de $350 \mathrm{~m}$, quase todos os fragmentos se conectaram (36). 
Na UG 2, a situação é mais crítica, visto que, mesmo com a expansão de borda máxima, apenas três dos 6 fragmentos passaram a se conectar. $\mathrm{E}$ na UG 3, composta por 12 fragmentos, a partir de uma expansão de borda de $30 \mathrm{~m}$, nove se conectaram e com a expansão máxima, quase todos os fragmentos passaram a se conectar (11).

\section{Simulação do cenário ambiental 1}

Noss (1987) e Pires, Pires e Santos (2004) defendem que a melhor estratégia para a manutençáo da integridade ecológica de uma paisagem seria interligar fragmentos isolados para que se possa permitir o fluxo de espécies de interior de hábitat. E também que o tamanho e o formato dos fragmentos possibilitem uma área núcleo razoável e índice de circularidade próximo de 1.

Assim, a proposta de criar este cenário para a área de estudo acompanha a hipótese de que à medida que a área dos fragmentos é ampliada, diminui a suscetibilidade dos mesmos e aumenta a área de hábitat de interior.

No cenário 0 , de um total de 55 fragmentos, 40 (72\%) foram considerados suscetíveis em função do seu tamanho e formato, um dado preocupante quando se pensa no equilíbrio do funcionamento ecológico de uma bacia hidrográfica.

Após a remodelagem desses fragmentos, o cenário 1 (Figura 6) passou a apresentar um total de 54 fragmentos, resultado da uniáo entre os fragmentos 14 e 15.

Utilizando-se o ArcGIS 9.3, os fragmentos vizinhos das áreas de cabruca tiveram suas áreas parcialmente aumentadas, suas bordas suavizadas através da diminuição das suas reentrâncias e sua forma aproximada à de um círculo. Essa medida permitiria uma diminuição da suscetibilidade dos fragmentos e, ainda assim, a manutenção do cultivo do cacau pelo sistema cabruca.

A modelagem aplicada ao formato dos 39 fragmentos considerados mais suscetíveis nas três unidades de gerenciamento produziu uma mudança no IC dos mesmos. No cenário 0 , nenhum fragmento aproxima-se do valor ideal $\mathrm{IC}=1$. Já no cenário 1 haveria um aumento no IC desses fragmentos. De um total de 39 fragmentos, 26 deles passariam a apresentar IC entre 0,8 e 1 , valores considerados próximos do ideal. 


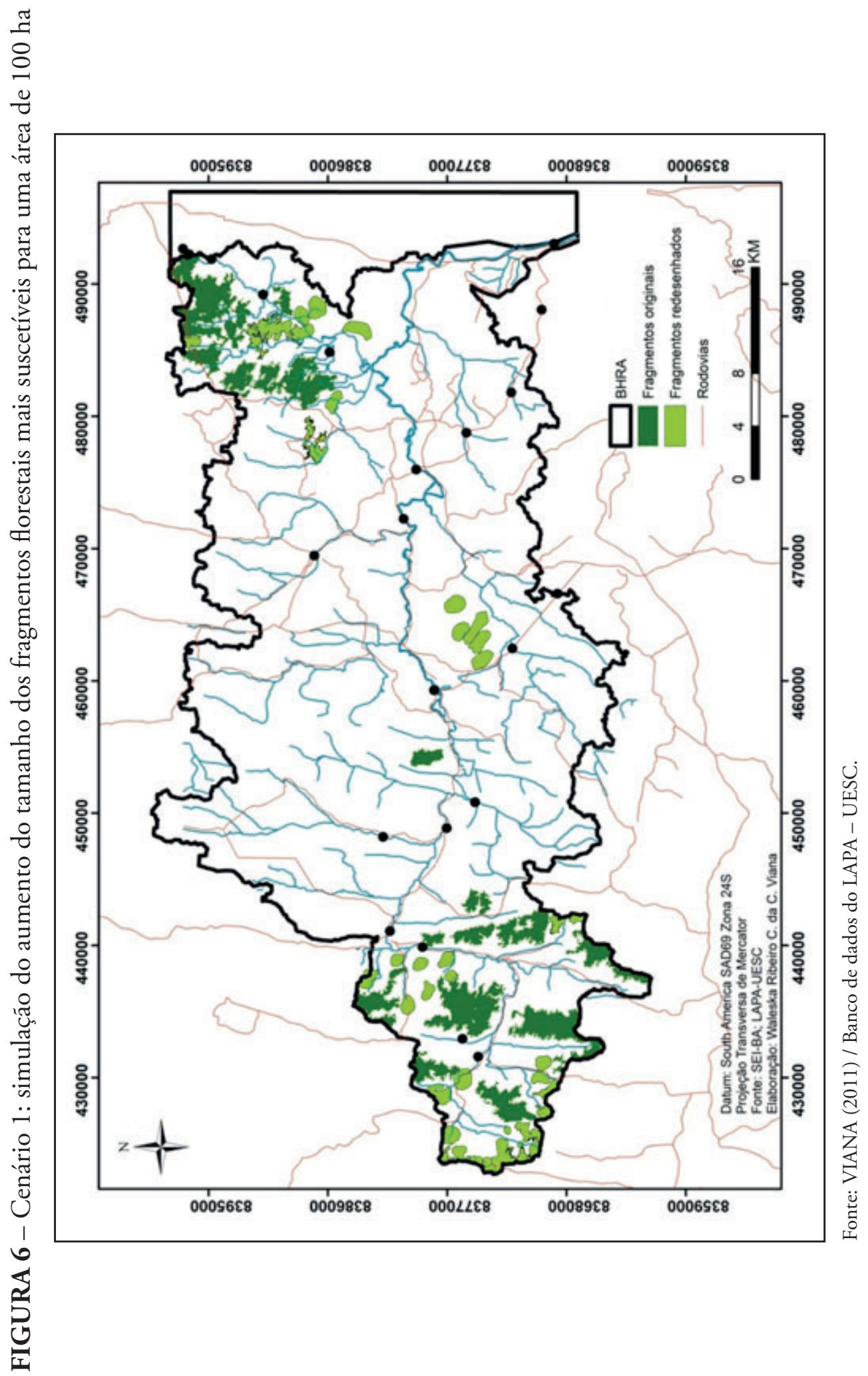


Assim como o formato dos fragmentos, também a conectividade é importante para a sua longevidade. Fragmentos isolados estáo fadados ao desaparecimento, pois o efeito de borda provoca o raleamento e a homogeneização do interior dos mesmos (VIANA; PINHEIRO, 1998). Além disso, para a manutenção da integridade ecológica da paisagem, é preciso manter sua diversidade estrutural e funcional. Segundo Pires, Pires e Santos (2004), em áreas fragmentadas, isso depende da conectividade entre fragmentos.

Nesse sentido, o cenário 2 (Figura 7) foi elaborado com base nas informaçóes obtidas no cenário 1, utilizando os fragmentos já ampliados. O principal objetivo da segunda simulação foi aumentar a conectividade entre os fragmentos a partir da criação de fragmentos de ligação (FL) em pontos estratégicos que serviriam como trampolins ecológicos. Esses fragmentos promovem um aumento na heterogeneidade da paisagem e atuam como refúgio para espécies que requerem ambientes particulares que só ocorrem nessas áreas (FORMAN; GODRON, 1986). Esses pontos foram localizados com base na simulação de sobreposição de bordas expandidas até $350 \mathrm{~m}$ e englobando áreas de nascentes, quando possível.

Foram criados 16 fragmentos de ligação (FL) distribuídos da seguinte forma: dez na UG1 (765,8 ha); um na UG2 (32 ha); e cinco na UG3 (292 ha). O tamanho desses fragmentos variou entre 13 e 300 ha e aumentou em 1.179 ha a área florestada na bacia. A porção oeste, que vem sofrendo com a destinação cada vez maior de áreas para a bovinocultura, foi a que recebeu a maior quantidade de FL.

Um fato relevante na UG1 é a combinação da criação dos FL com a localização dos rios. Atualmente, existem em torno dos afluentes do rio Almada muitas áreas destinadas à pastagem, uma associação negativa que acarreta o assoreamento dos rios e pisoteio de suas margens, entre outros problemas. Com a criação dos FL, alguns puderam funcionar como mata ciliar para sete trechos em rios diferentes. 


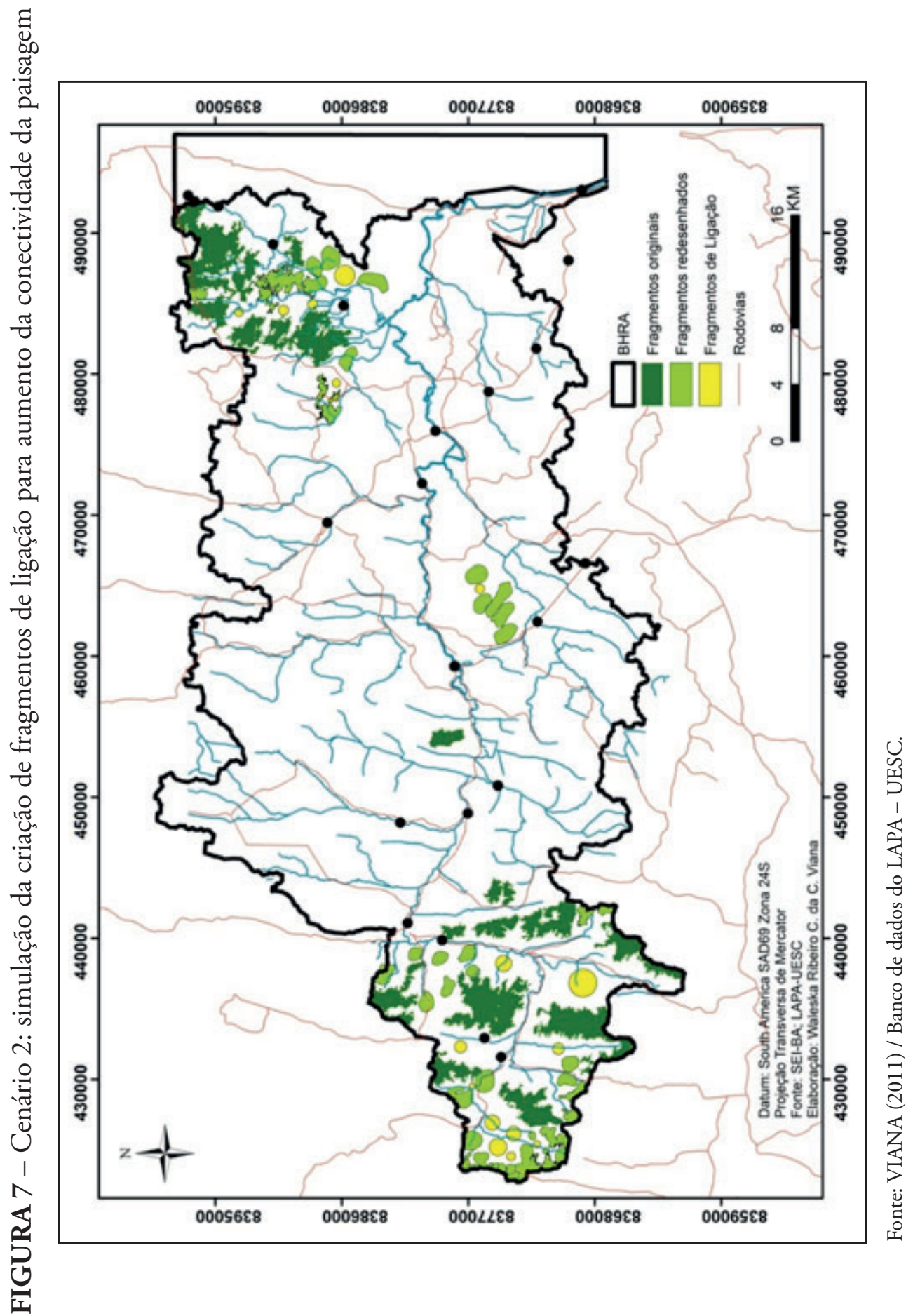


Se comparado aos cenários anteriores (cenário 0 e cenário 1 ), o cenário 2 apresentou, respectivamente, um aumento de 6,2\% e 4,5\% no total de fragmentos conectados, aumentando para 71 o número total de fragmentos florestais na área de estudo.

\section{Consideraçóes Finais}

A ocorrência de remanescentes de Mata Atlântica apenas de forma fragmentada na área de estudo implica no aumento de sua suscetibilidade ecológica. Aplicadas à fragmentação, as métricas da paisagem possibilitaram identificar as áreas com maior e menor suscetibilidade.

Através do mapeamento dos remanescentes de mata nativa foi possível constatar seu atual estágio de fragmentação, avaliando-se a distribuição espacial, quantidade, tamanho e formato dos fragmentos nas unidades de gerenciamento. E, através da criação de cenários ambientais, ainda foi possível avaliar o grau de conectividade da paisagem.

Os cenários 1 e 2 apresentaram dados relevantes no que tange às necessidades de restauraçáo florestal. Sugere-se a adoção de medidas de restauração nas áreas consideradas mais críticas, como na UG 2; de proteção das áreas prioritárias para a conservação do bioma Mata Atlântica, como na UG 3; e de recuperação das áreas de nascentes, como na UG 1. Desse modo, acredita-se garantir o equilíbrio dos sistemas ambientais que compóem a bacia do rio Almada, essencial para a continuidade dos serviços ecossistêmicos prestados por essa bacia que, por sua vez, são essenciais para o desenvolvimento das atividades agroflorestais e agropecuárias.

A significativa conectividade dos fragmentos (apenas um fragmento manteve-se isolado dos demais no cenário 0 após a expansão de borda de 350 $\mathrm{m}$ ), atrelada à resposta positiva com a diminuição do grau de suscetibilidade ao efeito de borda, através da remodelagem dos fragmentos, indica a necessidade de intervençáo no tamanho e formato dos mesmos, o que poderia ser feito por meio do reflorestamento das áreas indicadas no mapeamento. No entanto, a escala geográfica deve ser ajustada para abranger o nível de detalhamento necessário ao correto planejamento das açóes a serem implantadas. Finalmente, ressalta-se que a ampliação da conectividade dos fragmentos na bacia também deve considerar as suas especificidades com relação às necessidades para a manutenção da sua diversidade funcional, ou seja, a capacidade de dispersão e locomoção das espécies locais. 


\section{Referências}

BAHIA. GOVERNO DO ESTADO. Diagnóstico das bacias hidrográficas dos rios Cachoeira e Almada. Salvador: SEINFRA/SRH/UESC, 2001.

BELOVSKY, G. E. Extinction models and mammalian persistence. In: SOULÉ, M. Viable populations for conservation. Cambridge: Cambridge University Press, 1987. p. 35-58.

EMPRESA BRASILEIRA DE PESQUISA AGROPECUÁRIA - EMBRAPA. Sistema brasileiro de classificaçáo de solos. 2. ed. Rio de Janeiro: EMBRAPA Solos, 2006.

FORERO-MEDINA, G.; VIEIRA, M. V. Conectividade funcional e a importância da interação organismo-paisagem. Oecologia Brasiliensis, Rio de Janeiro, v. 11, n. 4, p. 493-502, 2007.

FORMAN, R. T. T. Some general principles of landscape and regional ecology. Landscape Ecology, v. 10, n. 3, p. 133-142, 1995.

FORMAN, R. T. T.; GODRON, M. Landscape ecology. New York: John Wiley \& Sons, 1986.

FRANCO, G. B. et al. Classificação geotécnica dos solos da bacia do rio Almada - Bahia. Caminhos de Geografia, Uberlândia, MG, v. 13, n. 42, p. 42-49, 2012.

GOMES, R. L. et al. Aspectos físico-ambientais e de uso e ocupação do solo na bacia hidrográfica do rio Almada - BA. Boletim de Geografia, Maringá, PR, v. 30, n. 2, p. 45-57, 2012.

GOMES, R. L. Avaliação da fragilidade ambiental e vulnerabilidade natural à perda de solo da bacia hidrográfica do rio Almada - Bahia. Boletim de Geografia, Maringá, PR, v. 31, n. 3, p. 41-53, 2013.

GOMES, R. L. et al. Panorama do uso e ocupação do solo presente nas áreas de preservaçáo permanente da bacia hidrográfica do rio Almada BA. Revista Geografia (UFPE), Recife, v. 30, n. 3, p. 98-115, 2013. 
GUEVARA, S.; PURATA, S. E.; VAN DER MAAREL, E. The role of remnant forest trees in tropical secondary succession. Vegetatio, v. 66, n. 2, p. 77-84, 1986.

HARRIS, L. D. The fragmented forest. Chicago: University of Chicago Press, 1984.

LANG, S.; BLASCHKE, T. Análise da paisagem com SIG. São Paulo: Oficina de Textos, 2009.

LAURENCE, W. F.; BIERREGAARD, R. O. Tropical forest remnants ecology, management and conservation of fragmented communities. Chicago: Chicago University Press, 1997.

METZGER, J. P. Estrutura da paisagem e fragmentação: análise bibliográfica. Anais da Academia Brasileira de Ciências, v. 71, n. 3-I, p. 445463, 1999.

MORAES, M. E. B. et al. Análise da Paisagem da Bacia Hidrográfica do Rio Almada (BA) com base na fragmentação da vegetaçáo. Caminhos de Geografia, Uberlândia, MG, v. 13, n. 41, p. 159-169, 2012.

NOSS, R. F. Corridors in real landscapes: a reply to Symberloff and Cox. Conservation Biology, Cambridge, v. 1, n. 2, p. 159-164, 1987.

PÉRICO, E. et al. Efeitos da fragmentação de habitats sobre comunidades animais: utilização de sistemas de informação geográfica e de métricas da paisagem para seleção de áreas adequadas a testes. In: SIMPÓSIO BRASILEIRO DE SENSORIAMENTO REMOTO, 12., 2005, Goiânia, GO. Anais... Goiânia, GO: INPE, 2005. v. 2. p. 2339-2346.

PIRES, J. S.; SANTOS, J. E. dos; DEL PRETTE, M. E. A utilização do conceito de bacia hidrográfica para a conservação dos recursos naturais. In: SCHIAVETTI, A.; CAMARGO, A. F. M. (Eds.) Conceitos de bacias hidrográficas: teorias e aplicaçôes. Ilhéus, BA: Editus, 2002. p. $17-$ 35 .

PIRES, J. S. R.; PIRES, A. M. Z. C.; SANTOS, J. E. Avaliação da integridade ecológica em bacias hidrográficas. In: SANTOS, J. E.; CAVALHEIRO, F.; PIRES, J. S. R.; OLIVEIRA, C. H.; PIRES, A. M. Z. C. R. (Orgs.) Faces da polissemia da paisagem: ecologia, planejamento e percepção. São Carlos, SP: Rima, 2004. p.123-150. 
RANTA, P. et al. The fragmented Atlantic Rainforest of Brazil: size, shape and distribution of forest fragments. Biodiversity and Conservation, Cambridge, v. 7, n. 3, p. 385-403, 1998.

SAMBUICHI, R. H. R. et al. Cabruca agroforests in Southern Bahia, Brazil: tree components, management practice and tree species conservation. Biodiversity and Conservation, Cambridge, v. 21, n. 4, p. 10551077, 2012.

SANTANA, L. M. Análise física e química da água e estrutura da comunidade fitoplanctônica (sul da Bahia). 2001. 120 f. Dissertação (Mestrado) - Universidade Estadual de Santa Cruz, Ilhéus, BA, 2011.

SCHROTH, G. et al. Conservation in tropical landscape mosaics: the case of the cocoa landscape of Southern Bahia, Brazil. Biodiversity and Conservation, Cambridge, v. 20, n. 8, p. 1635-1654, 2011.

STEINITZ, C. et al. (Eds.) Alternatives futures for the Snyderville Basin, Summit County, Utah. Cambridge: Harvard University/Graduate School of Design, 1991.

VIANA, V. M.; PINHEIRO, L. A. F. V. Conservação da biodiversidade em fragmentos florestais. Série Técnica IPEF, Piracicaba, SP, v. 12, n. 32, p. 25-42, 1998.

VIANA, W. R. C. da C. Fragmentaçáo florestal e diversidade de hábitats na bacia hidrográfica do rio Almada, sul da Bahia, Brasil. 2011. 86 f. Dissertação (Mestrado) - Universidade Estadual de Santa Cruz, Ilhéus, BA, 2011. 


\title{
Utilizaçáo de técnicas de mapeamento geotécnico para a avaliaçáo da adequabilidade da bacia do Almada para implantaçáo de obras lineares
}

\author{
Ronaldo Lima Gomes \\ Eduardo Antonio Gomes Marques
}

\section{Introdução}

A Bacia Hidrográfica do Rio Almada (BHRA) localiza-se na região Sul do estado da Bahia, mais precisamente na denominada microrregiáo de Ilhéus-Itabuna, onde encontra-se área significativa do bioma Mata Atlântica, além de florestas secundárias, restingas e manguezais.

No início da década de 90, com o objetivo de proteger a biodiversidade local, disciplinar o processo de ocupação e assegurar o uso sustentável de seus recursos naturais, foi criada a Área de Proteção Ambiental (APA) da Lagoa Encantada, que englobou grande parte da área da BHRA com sua ampliação em 2003. Tal ampliaçáo justifica-se pela importância da área para a conservaçáo de espécies endêmicas, pela sua diversidade de ecossistemas, beleza cênica e potencial ecoturístico. Recentemente, indo de encontro à afinidade turística da regiáo, a BHRA tornou-se cenário de implantação de grandes empreendimentos, a exemplo de um complexo intermodal de transporte formado por porto, retroárea portuária, ferrovia e rodovia, com o objetivo de criar um corredor de exportaçáo para o escoamento de minérios e grãos do centro-oeste e oeste da Bahia. Atualmente, tal empreendimento encontra-se em fase de licenciamento ambiental e estabelece-se como um debate evidente em todos os setores da sociedade do Sul da Bahia.

Neste contexto, através da aplicação de técnicas de mapeamento geotécnico, este capítulo apresenta um estudo sobre a adequabilidade da BHRA diante da implantação de obras lineares (rodovias, ferrovias, linhas 
de transmissão e dutos), considerando suas características do meio físico e de uso e ocupaçáo do solo, além do mapeamento de suas áreas de preservação permanente.

No Brasil, a utilização de técnicas de mapeamento geotécnico que enfatizam o reconhecimento de potencialidades e limitaçóes do terreno em decorrência da implantação de obras lineares é apresentada em diversos trabalhos (Mattos, Rueda e Silva, 2010; Akiossi et al., 2005; Barbosa; Cerri, 2004; Caetano, Ohara e Mattos, 2002; Feres; Lorandi, 1998; Carregã; Balzan, 1998). Com relaçáo aos estudos e práticas de mapeamento geotécnico para implantação de dutos e linhas de transmissão, citam-se os trabalhos de Figueira, Figueira e Rodrigues (2010), Corteletti e Sobreira (2008), Lázaro, Moura e Merigui (2005), Silva e Zaine (2005) e Amarante et al. (2005).

De forma geral, os métodos empregados em trabalhos correlatos anteriormente realizados no Brasil retratam, preferencialmente, as potencialidades e limitaçóes do meio físico diante da implantaçáo de obras lineares, sem considerar, em muitos casos, aspectos ambientais e de uso e ocupação do solo.

Do exposto, o produto final aqui apresentado constitui-se de um mapeamento cartográfico que retrata o panorama de adequabilidades à interveniência de empreendimentos lineares na área de estudo.

\section{Métodos e Técnicas de Pesquisa}

O método adotado para a elaboração da carta de adequabilidade à implantação de obras lineares da BHRA apresenta quatro etapas, conforme apresentado na Figura 1 e descrito a seguir.

Em função do tamanho da bacia e da base plani-altimétrica existente, os trabalhos de cartografia foram desenvolvidos na escala 1: $100.000 \mathrm{com}$ a utilização e adaptação dos dados das folhas topográficas SD.24-Y-B-VI (Itabuna-2143), SD.24-Y-B-V (Ibicaraí-2142), SD.24-Y-B-III (Ubaitaba-2099) do Instituto Brasileiro de Geografia e Estatística (IBGE).

A primeira etapa do método visou caracterizar os principais componentes ambientais da BHRA a partir da elaboração de mapas básicos fundamentais (substrato rochoso, solos e uso e ocupação do solo), além de cartas básicas (declividade e hipsometria). Os dados de declividade e hipsometria foram obtidos a partir da análise do MDT (Modelo Digital 
do Terreno), gerado pela manipulação de dados matriciais disponíveis pelo TOPODATA. Informaçóes sobre o substrato rochoso da BHRA foram obtidas através de consulta ao "Programa Levantamentos Geológicos Básicos do Brasil - Folha SD.24-Y-B-VI" (ARCANJO,1997). Já os dados de solos foram obtidos do trabalho de Franco (2010). 
FIGURA 1 - Fluxograma do método adotado

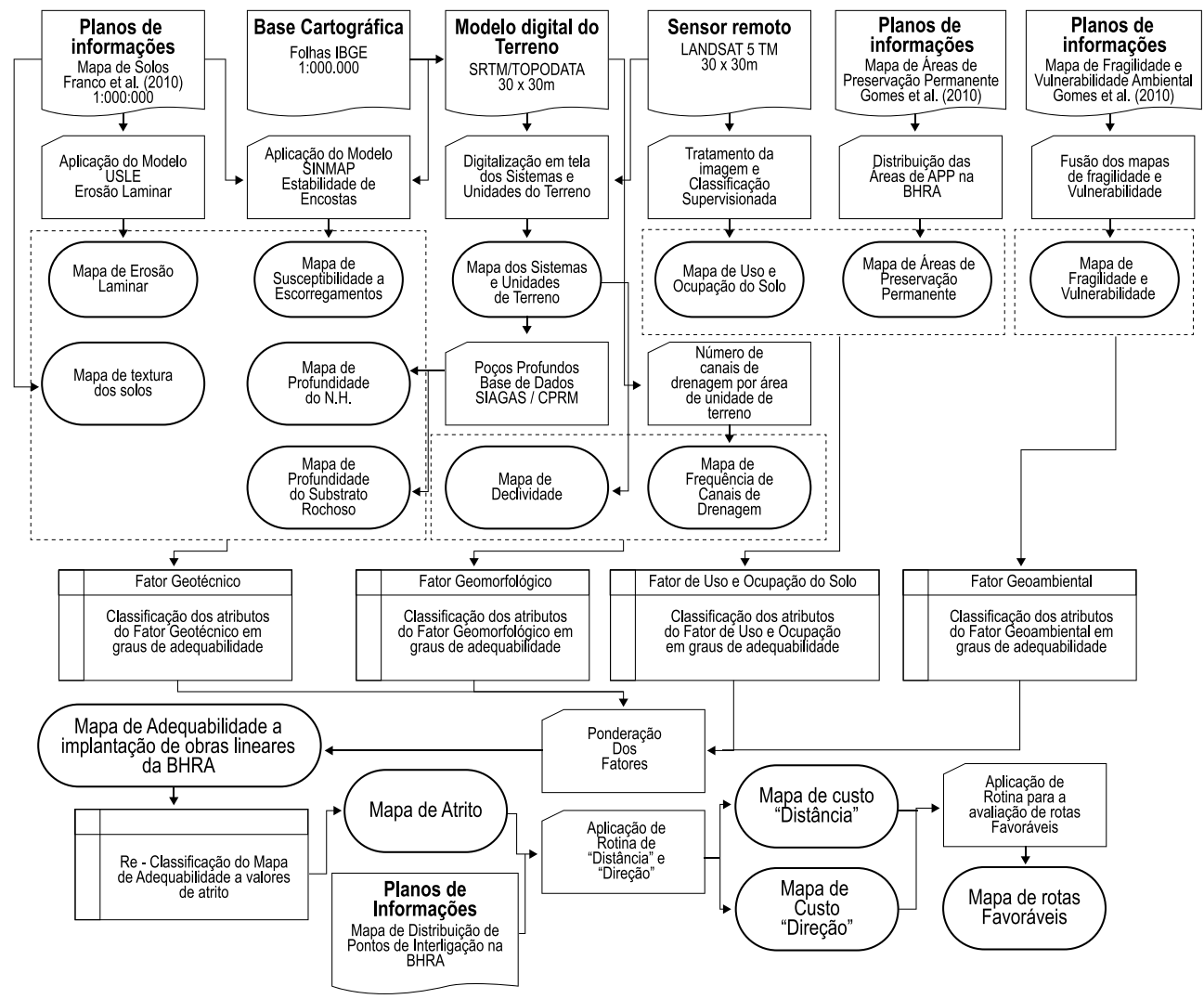

Fonte: elaborado pelos autores.

Para a apresentação do panorama de uso e ocupação do solo da BHRA, foram utilizadas imagens de satélite LANDSAT 5 TM, órbitas 215/070 e 216/070 de 2011 (Figura 2). Para a manipulação das imagens, incluindo processos de composição de bandas, correçôes atmosféricas e geométricas, foi utilizado o software ERDAS imagine 9.1. Preparada a imagem, iniciou-se o processo de classificação supervisionada, tendo em vista a caracterização do uso e ocupação do solo da bacia.

Ainda nesta etapa, foram adaptados e consolidados dados pré-existentes de mapeamento das Áreas de Preservaçáo Permanente (APP), formas de relevo e de fragilidades ambientais do terreno. A distribuição de APP foi obtida a partir da manipulação de arquivos digitais (shapefile) gerados em trabalhos anteriores (GOMES et al., 2013). 


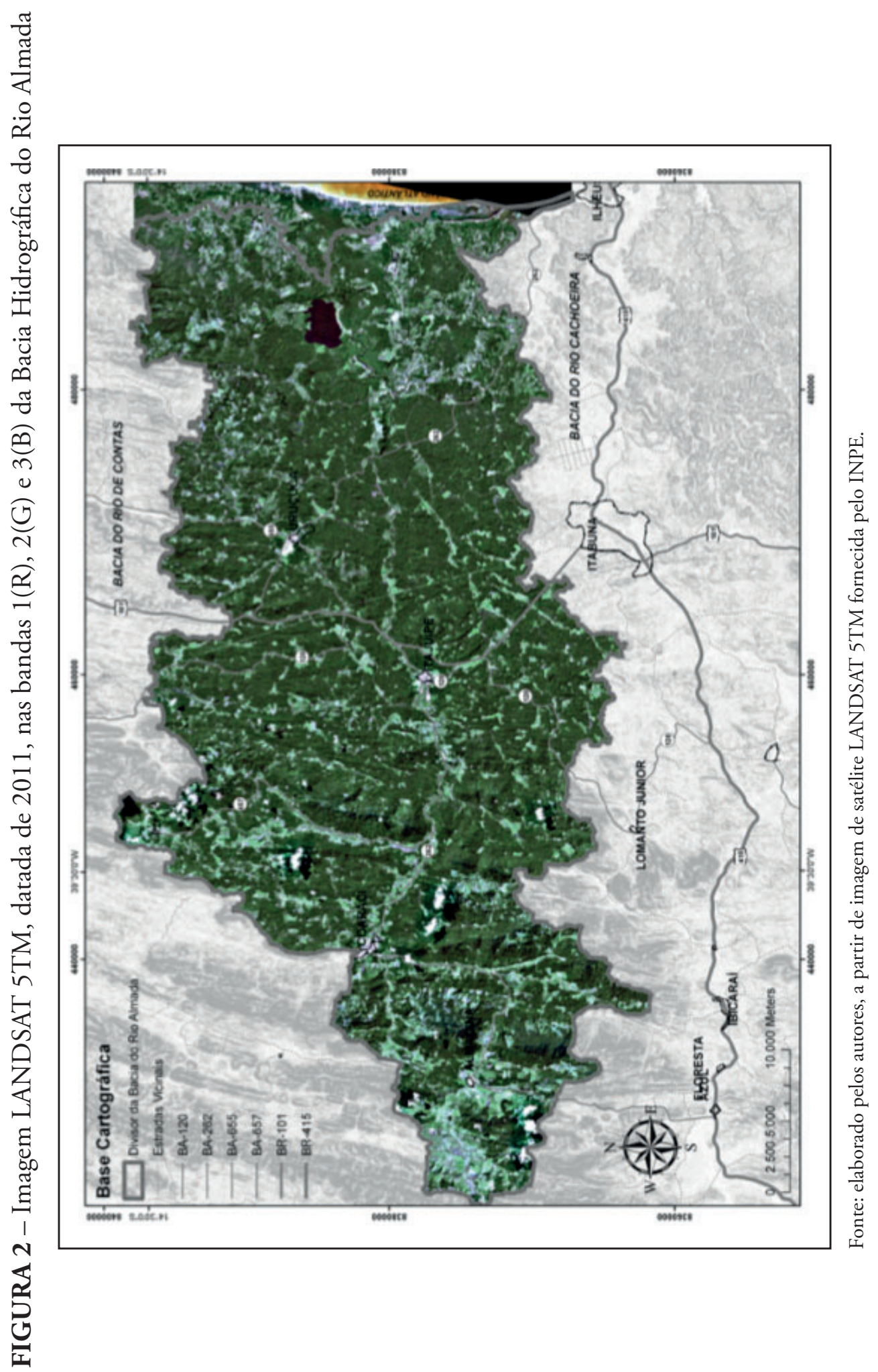


As informaçôes sobre os sistemas e unidades de relevo da BHRA (Figura 4) foram obtidas a partir da manipulação dos arquivos digitais do mapeamento realizado por Silva e Gomes (2010), que aplicaram a técnica de avaliação do terreno na BHRA. Estes dados foram úteis para a espacializaçáo de atributos, tais como profundidade do substrato rochoso, profundidade do nível d'água e espessura de solos. Já o panorama de distribuição das fragilidades ambientais foi obtido a partir do banco de dados geográficos para a BHRA elaborado por Gomes et al. (2013). Neste trabalho, os dados do meio físico e de uso e ocupaçáo do solo foram avaliados visando a determinação das fragilidades e vulnerabilidades do terreno (Figura 5), de acordo com as propostas metodológicas de Ross (1994) e Crepani et al. (1996).

A segunda etapa do método teve como objetivo a interpretação dos dados gerados na etapa anterior, tendo em vista o conhecimento das potencialidades e limitaçóes do meio físico-ambiental para a implantação de obras lineares. Nesse contexto, foram produzidas as cartas interpretativas de profundidade do nível d'água, profundidade do substrato rochoso, textura dos solos, frequência de canais de drenagem, suscetibilidade a erosão laminar e suscetibilidade a escorregamentos. Os dados de profundidade do nível d'água e do substrato rochoso foram obtidos no banco de dados do Sistema de Informaçôes de Águas Subterrâneas (SIAGS), desenvolvido pelo Serviço Geológico do Brasil (SGB). De acordo com o SIAGS, na área da BHRA encontram-se catalogados 14 poços. Para a extrapolação lateral das informaçóes pontuais dos poços, utilizou-se a distribuição das manchas das unidades de terreno. Dessa forma, foram atribuídos valores de profundidade do substrato rochoso e de nível d'água subterrâneo a cada uma das unidades de terreno mapeadas na BHRA. Com relaçáo à textura dos solos, os dados foram obtidos a partir da manipulação das informaçóes geradas pelo mapeamento de solos da BHRA realizado por Franco (2010). 


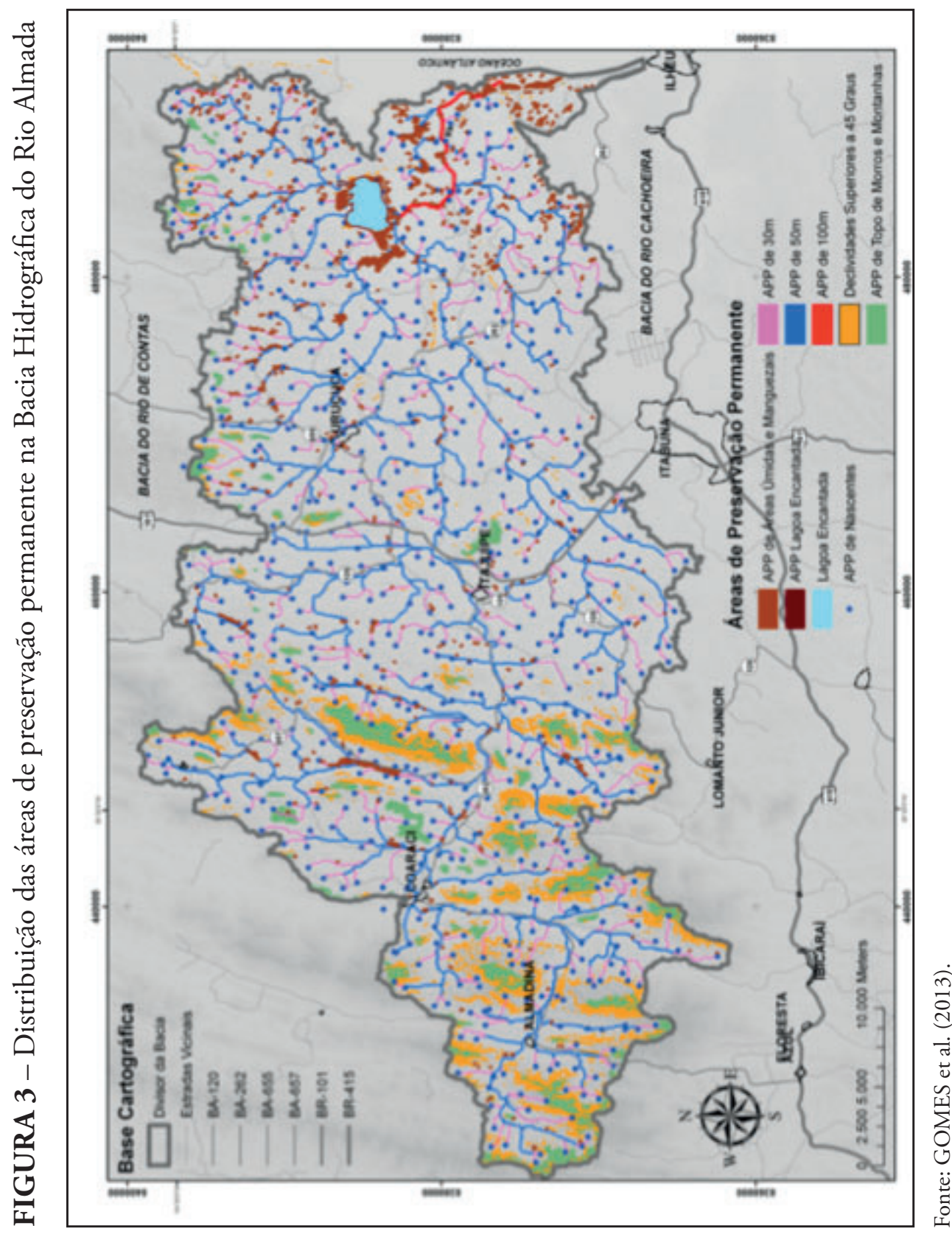




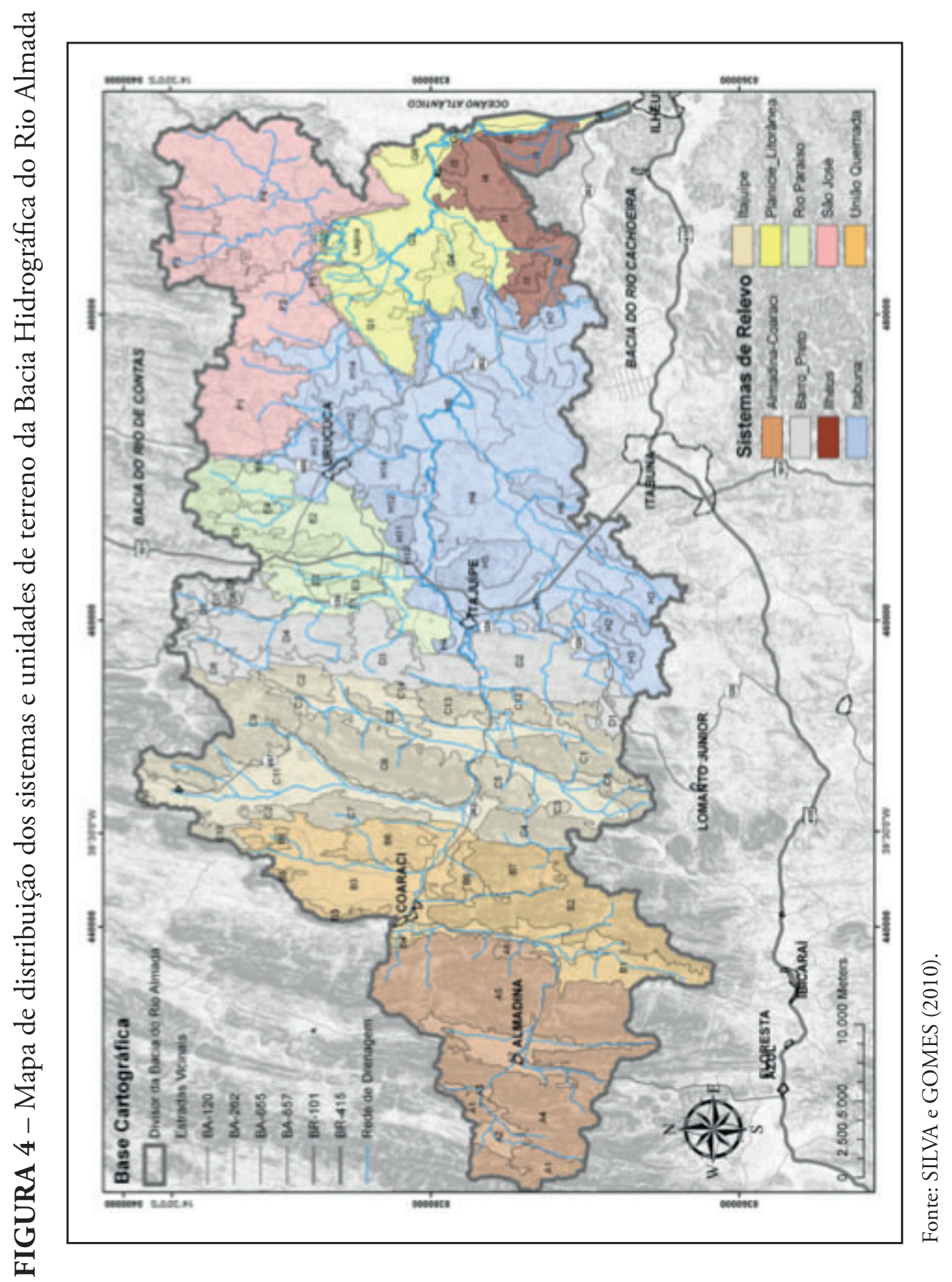




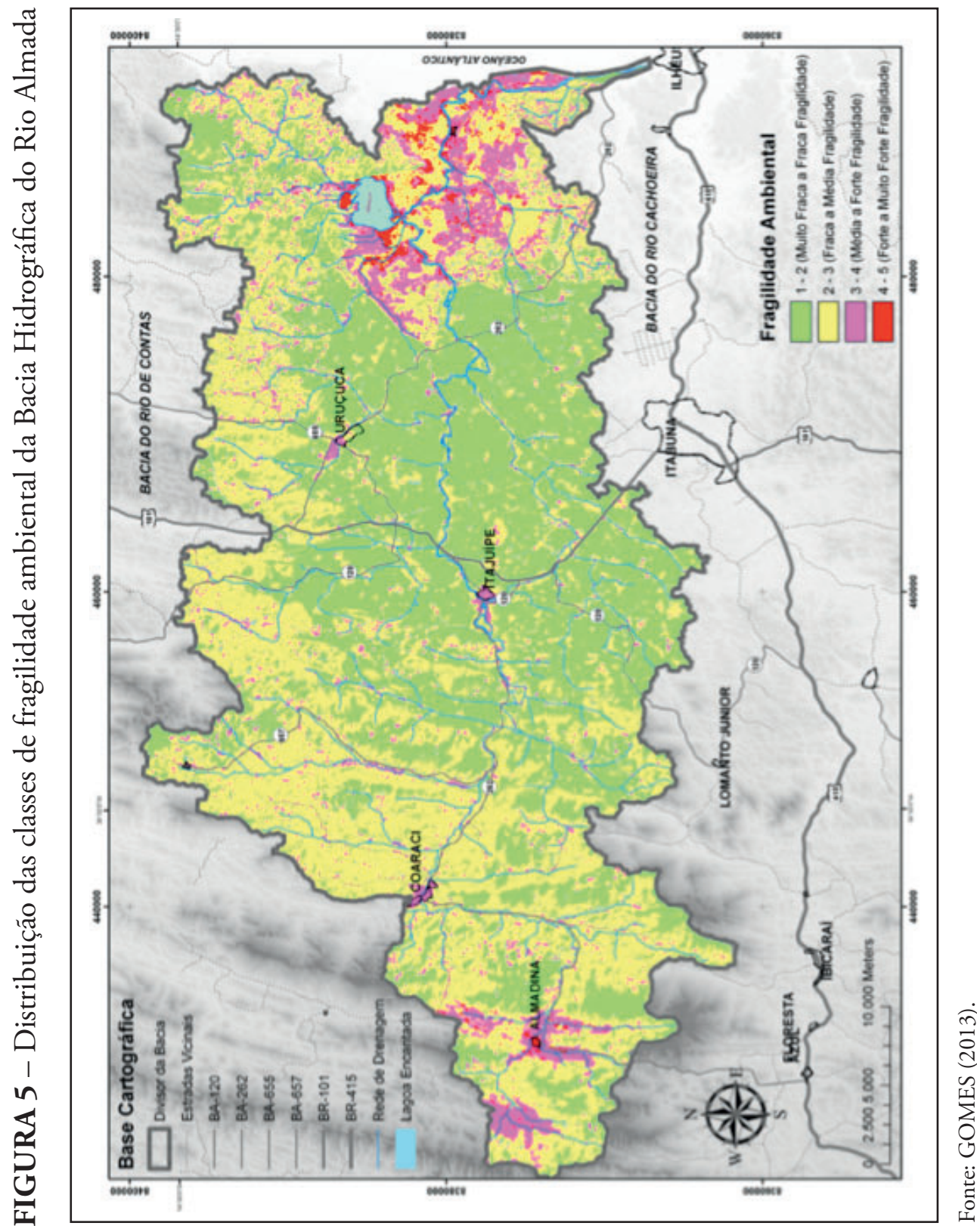

Os dados das unidades de terreno também foram utilizados para a definição da frequência de canais de drenagem, caracterizada pela razão entre o somatório do comprimento de canais de drenagem com a área da unidade de terreno em que se encontram os canais.

O cálculo da perda de solo por erosão foi realizado através da aplicação da Equação Universal de Perdas de Solo (EUPS), proposta por Wischmeier e 
Smith (1978), a partir da utilização de parâmetros de erosividade das chuvas, erodibilidade dos solos, fator topográfico, fator de cobertura vegetal e práticas conservacionistas. Já a distribuiçáo da suscetibilidade a escorregamentos em encostas foi determinada a partir da aplicação do modelo SINMAP (Stability Index Mapping), desenvolvido por Pack, Tarboton e Goodwin (1998) e implementado na forma de extensão do ArcGIS 9.2. O resultado da aplicação do SINMAP representa a distribuição de um índice de estabilidade (IE) que define a probabilidade do fator de segurança ser superior ou inferior a 1. Maiores detalhes de execução metodológica para a aplicação da EUPS e do modelo SINMAP na BHRA podem ser obtidos em Gomes et al. (2010).

A terceira etapa do método visou organizar as informaçóes dos atributos do meio físico e de uso e ocupação do solo, definidos nas etapas 1 e 2, em classes de adequabilidade à implantação de obras lineares, de acordo com adaptação da proposta metodológica de Zuquette (1993). Para tanto, os atributos, consolidados sob a forma de Planos de Informaçáo (PI) em Sistemas de Informação Geográfica (SIG), foram subdivididos em quatro grupos - fator geotécnico, fator geomorfológico, fator geoambiental e fator de uso e ocupação do solo - e tiveram os seus valores e características enquadrados em quatro classes de adequabilidade (favorável, moderada, severa e restritiva), conforme apresentado na Tabela 1. 
TABELA 1 - Ponderação dos atributos físico-ambientais utilizados para a avaliação da adequabilidade à implantação de obras lineares na Bacia do Rio Almada

\begin{tabular}{|c|c|c|c|c|c|}
\hline \multirow{2}{*}{ Fator } & \multirow{2}{*}{ Atributo } & \multicolumn{4}{|c|}{ Classes de adequabilidade } \\
\hline & & favorável & moderada & severa & Restritiva \\
\hline \multirow{5}{*}{$\begin{array}{l}\text { Geotéc- } \\
\text { nico }\end{array}$} & $\begin{array}{l}\text { profundidade do } \\
\text { nível d'água subter- } \\
\text { râneo }(\mathrm{m})\end{array}$ & $>5$ & $1-5$ & $0,5-1$ & $<0,5$ \\
\hline & $\begin{array}{l}\text { profundidade do } \\
\text { substrato rochoso } \\
\text { (m) }\end{array}$ & $>5$ & $2-4$ & $2-1$ & $<1$ \\
\hline & textura dos solos & arenosa & silto-arenosa & silto-argilosa & Argilosa \\
\hline & $\begin{array}{l}\text { suscetibilidade à } \\
\text { erosão laminar - usle } \\
\text { (ton/ha/ano) }\end{array}$ & $<10$ & $10-50$ & $50-200$ & $>200$ \\
\hline & $\begin{array}{l}\text { suscetibilidade a } \\
\text { escorregamentos em } \\
\text { encostas - sinmap } \\
\text { (ie) }\end{array}$ & $>1,5$ & $1-1,5$ & $0,5-1$ & $<0,5$ \\
\hline \multirow[b]{2}{*}{$\begin{array}{l}\text { Geo- } \\
\text { morfo- } \\
\text { lógico }\end{array}$} & declividade (\%) & $<5$ & $5-15$ & $15-20$ & $>20$ \\
\hline & $\begin{array}{l}\text { frequência de canais } \\
\text { de drenagem }\left(\mathrm{n}^{\mathrm{o}}\right. \\
\text { canais } / \mathrm{km})\end{array}$ & $<1$ & $2-3$ & $3-4$ & $>4$ \\
\hline $\begin{array}{l}\text { Geoam- } \\
\text { biental }\end{array}$ & $\begin{array}{l}\text { fragilidade ambien- } \\
\text { tal }\end{array}$ & $1-1,75$ & $1,75-2,5$ & $2,5-3,25$ & $3,25-4,0$ \\
\hline \multirow{2}{*}{$\begin{array}{l}\text { Uso e } \\
\text { ocupa- } \\
\text { çáo do } \\
\text { solo }\end{array}$} & presença de APP & & & & $\mathrm{APP}$ \\
\hline & $\begin{array}{l}\text { uso e ocupação do } \\
\text { solo }\end{array}$ & $\begin{array}{l}\text { áreas de- } \\
\text { gradadas e } \\
\text { pastagens }\end{array}$ & gramíneas & $\begin{array}{l}\text { floresta } \\
\text { associada à } \\
\text { cultura }\end{array}$ & $\begin{array}{l}\text { áreas } \\
\text { úmidas e } \\
\text { floresta }\end{array}$ \\
\hline
\end{tabular}

Fonte: adaptado de Zuquette (1993).

Por fim, a quarta etapa visou a elaboraçáo da Carta de Adequabilidade à Implantação de Obras Lineares na Bacia Hidrográfica do Rio Almada. Para tanto, foi estabelecido um peso para cada classe de adequabilidade, sendo: favorável (1), moderada (2), severa (3) e restritiva (4). Em seguida, em ambiente SIG, aplicou-se a álgebra de mapas com o objetivo de estabelecer o 
valor médio de adequabilidade para cada um dos quatro fatores estudados. Posteriormente, os fatores foram somados e foi calculada a média representativa de adequabilidade dos quatro fatores avaliados. A equaçáo 1, apresentada a seguir, demonstra o algoritmo utilizado na ponderaçáo dos atributos.

\section{$\mathrm{AIOL}=[(\mathrm{NH}+\mathrm{SR}+\mathrm{TS}+\mathrm{SL}+\mathrm{SE}) / 5]^{*} \mathbf{0 , 2 5}+[(\mathrm{DE}+\mathrm{FD}) / 2]^{*} \mathbf{0 , 2 5}$ $+\mathrm{FA}^{*} \mathbf{0 , 2 5}+[(\mathrm{AP}+\mathrm{US}) / 2]^{*} 0,25$}

em que: $\mathrm{AIOL}=$ adequabilidade à implantação de obras lineares; $\mathrm{NH}=$ profundidade do nível d'água; $\mathrm{SR}=$ profundidade do substrato rochoso; $\mathrm{TS}=$ textura dos solos; $\mathrm{SL}=$ suscetibilidade à erosão laminar; $\mathrm{SE}=$ suscetibilidade à escorregamentos em encostas, $\mathrm{DE}=$ declividade, $\mathrm{FD}=$ frequência de canais de drenagem; $\mathrm{FA}=$ fragilidade ambiental; $\mathrm{AP}=$ presença de $\mathrm{APP}$; e US= uso e ocupação do solo.

Após o conhecimento da distribuição das adequabilidades à implantação de obras lineares na área em estudo, aplicou-se rotina de apoio à decisão, no sentido de avaliar as rotas mais favoráveis à implantação de obras lineares na BHRA.

Para tanto, foram selecionados dez pontos de saída e chegada, abrangendo sedes municipais, pontos de entrada e saída de rodovias, pontos estratégicos associados a centros de pesquisa e universidades. Em seguida, foi criada uma superfície de atrito com a adaptação dos dados gerados pelo mapa de adequabilidade à implantação de obras lineares. A superfície de atrito estabelece o grau de dificuldade de transposiçáo, ou seja, os custos associados com o movimento através do terreno (trajeto) exercido por valores/pesos impostos às classes de adequabilidade mapeadas.

Para a criação da superfície de atrito, utilizou-se a extensão Spatial Analyst do software ArcGIS 9.3, mais especificamente o módulo Cost Distance.

Por este procedimento, inicialmente, o grid de informaçóes das classes de adequabilidade foi correlacionado a valores de atrito, em que se atribui à classe favorável o valor de atrito básico igual a 1; à classe de adequabilidade moderada, valor de atrito igual a 100; à classe de adequabilidade severa, valor de atrito igual a 800; e à classe restritiva, valor de atrito igual a 1.000. Por esta ponderaçáo, as classes de adequabilidade severa e restritiva recebem elevados valores de atrito no sentido de evitar que o traçado calculado cruze áreas do terreno contendo atributos de qualidade construtiva indesejáveis associados a áreas com restriçôes ambientais. 


\section{Aspectos físico-ambientais da bacia do rio Almada}

A maior parte da BHRA é formada por um substrato rochoso cristalino, de idade pré-cambriana, agrupado, de acordo com Arcanjo (1997), no Domínio Coaraci-Itabuna, que compreende os Complexos Ibicaraí-Buerarema, São José e Almadina, onde ocorrem, além de granitoides granulitizados tipo Ibirapitanga-Ubaitaba, magmatismos de idade brasiliana, representados pela suíte intrusiva Itabuna por corpos de básicas intrusivas e por diques máficos. Com relaçáo às coberturas sedimentares fanerozoicas, estas englobam os sedimentos mesozoicos da Bacia Sedimentar do Rio Almada, os sedimentos Tércio-quaternários da Formação Barreiras e os sedimentos recentes das Planícies Quaternárias.

Quanto às formas de relevo, os modelados de acumulação associamse, principalmente, a formas de acumulação marinha (cordóes arenosos e planícies costeiras), acumulaçóes fluviais (depósitos de canal e de planícies aluvionares), praias e mangues atuais. Já os modelados de dissecação referem-se às unidades de relevo resultantes do processo de dissecaçáo de rochas do embasamento cristalino e de sedimentos mesozoicos da Bacia Sedimentar do Rio Almada (GOMES et al., 2010).

De acordo com o mapeamento realizado por Franco (2010), os principais tipos de solos da BHRA em termos de primeiro nível categórico são: neossolos, plintossolos, gleissolos, argissolos, cambissolos e vertissolos.

Com relaçáo ao panorama de uso e ocupação do solo, as áreas antropizadas (pastagens, gramíneas, solo exposto e áreas urbanas/vilas) correspondem a aproximadamente $22 \%$ da área total da BHRA, enquanto as áreas de mata, cabruca e manguezal correspondem a 77\%. O restante, 1\%, refere-se a áreas de superfície aquática associadas à rede de drenagem da bacia e da Lagoa Encantada. Já os dados de suscetibilidade à erosão laminar remetem a um cenário em que as classes de adequabilidade severa e moderada associam-se às áreas mais íngremes do relevo, ocorrentes de forma predominante na porção oeste da bacia. Comportamento semelhante dá-se com relação aos dados de suscetibilidade a escorregamentos em encostas, nos quais, de forma geral, as classes de adequabilidade moderada, severa e restritiva ocorrem associadas às encostas íngremes do relevo serrano na porção oeste da bacia. 


\section{Adequabilidade dos atributos físico-ambientais à implantaçáo de obras lineares}

A adequabilidade à implantação de obras lineares de cada atributo, obtida a partir da classificação dos valores apresentados na Tabela 1, pode ser visualizada no mosaico da Figura 6.

De acordo com a Figura 6a, as características de profundidade do nível d'água subterrâneo apresentam valores de adequabilidade favorável à moderada em grande parte da bacia. De forma geral, os valores favoráveis associam-se às porçôes mais elevadas do relevo, enquanto a classe de adequabilidade moderada associa-se aos fundos de vale. Já a classe de adequabilidade severa possui a sua ocorrência controlada pela distribuiçáo dos sedimentos mesozoicos da Bacia Sedimentar do Rio Almada e dos sedimentos recentes inconsolidados da planície costeira, podendo aumentar a restriçáo em áreas de ocorrência de alagamentos, predominantemente localizadas nas proximidades da calha do rio Almada em seu trecho costeiro.

A análise da adequabilidade da profundidade do substrato rochoso remete a uma distribuição na área da BHRA, controlada pela espessura de materiais inconsolidados que repousam sobre da amostra impenetrável à percussão (Figura 6b). Nesse contexto, na área de ocorrência do substrato cristalino, a adequabilidade varia de favorável a severa em função da litologia presente, do tipo de modelado do relevo e dos aspectos climáticos. A porção oeste da bacia, que apresenta valores de índices pluviométricos anuais inferiores aos da porção litorânea, possui a tendência de apresentar perfis de materiais inconsolidados de pequena espessura e baixa maturidade textural, apresentando-se, muitas vezes, pedregosos. Tais características podem ser observadas nos perfis localizados nas proximidades do município de Almadina, onde o substrato rochoso, formado por metassedimentos granulitizados, sustenta um relevo de morros e serras. Por outro lado, as litologias granítico-gnáissicas, localizadas em relevo serrano, ocorrente entre os municípios de Coaraci e Itajuípe, apresentam espessos perfis de alteração que podem chegar a $15 \mathrm{~m}$. Já nas partes central e costeira da bacia predomina a adequabilidade moderada em função do aumento de espessura dos perfis de alteraçáo do substrato cristalino e da profunda cota do impenetrável na área da planície costeira.

Com relaçáo à adequabilidade da textura dos solos (Figura 6c), podese afirmar que os solos predominantemente arenosos, como os espodosso- 
los e neossolos quartzo areníticos, estão localizados na porção litorânea da bacia. E os luvissolos ocorrem na porçáo oeste da mesma A adequabilidade severa ocorre associada a solos de textura predominantemente argilosa, a exemplo das áreas de domínio dos argissolos, dispersas pela bacia.

O panorama da suscetibilidade à erosáo laminar na BHRA (Figura 6d), calculado a partir da aplicação da equação universal de perda de solo, remete a um cenário em que as classes de adequabilidade severa e moderada associam-se às áreas mais íngremes do relevo, ocorrentes de forma predominante na porção oeste da bacia. Comportamento semelhante se dá com relação à adequabilidade da suscetibilidade a escorregamentos em encostas (Figura 6e), onde, de forma geral, as classes de adequabilidade moderada, severa e restritiva ocorrem associadas às encostas íngremes do relevo serrano da porção oeste da bacia.

Com relaçáo à análise dos atributos do fator geomorfológico, quanto à declividade (Figura 6f), as classes de adequabilidade severa e restritiva ocorrem de forma mais expressiva na porçáo oeste da BHRA, mais precisamente a partir de Itajuípe, onde predominam morros e serras com amplitudes que variam de 200 a $600 \mathrm{~m}$ e topos que alcançam altitudes de até $1.040 \mathrm{~m}$. Nas outras partes da bacia, de forma mais proeminente, ocorrem as classes de adequabilidade favorável à moderada com bolsóes de adequabilidade severa associadas a zonas de morros isolados e distribuídos na porção nordeste em área da Serra do Conduru. Já com relação à adequabilidade da frequência dos canais de drenagem, esta ocorre de forma favorável em grande parte da bacia (Figura $6 \mathrm{~g}$ ).

No que diz respeito ao fator geoambiental, a distribuiçáo das classes de adequabilidade severa e restritiva associa-se, predominantemente, a trechos de declividades superiores a $20 \%$, situados na porção oeste da bacia, e a áreas de ocorrência de substrato rochoso sedimentar, relacionado aos sedimentos mesozoicos e também aos inconsolidados recentes (Figura 6h). A classe de adequabilidade moderada predomina na BHRA em áreas associadas à distribuição do substrato rochoso cristalino e onde, preferencialmente, desenvolvem-se as classes de solos dos latossolos e argissolos,. Já a classe de adequabilidade favorável associa-se às calhas da rede de drenagem em virtude das baixas declividades.

Com relaçáo à vulnerabilidade e fragilidades das tipologias de uso e ocupação do solo (Figura 6i), ocorre na BHRA o predomínio das classes de adequabilidade favorável e moderada em função da grande extensão dos domínios de "cabruca" e áreas antropizadas por pastagens, áreas urbanas e 
solo exposto. As classes de adequabilidade severa e restritiva associam-se a porçóes da bacia cobertas por florestas e APP.

FIGURA 6 - Distribuição das adequabilidades dos fatores geotécnicos, geomorfológicos, geoambientais e de uso e ocupação do solo na BHRA

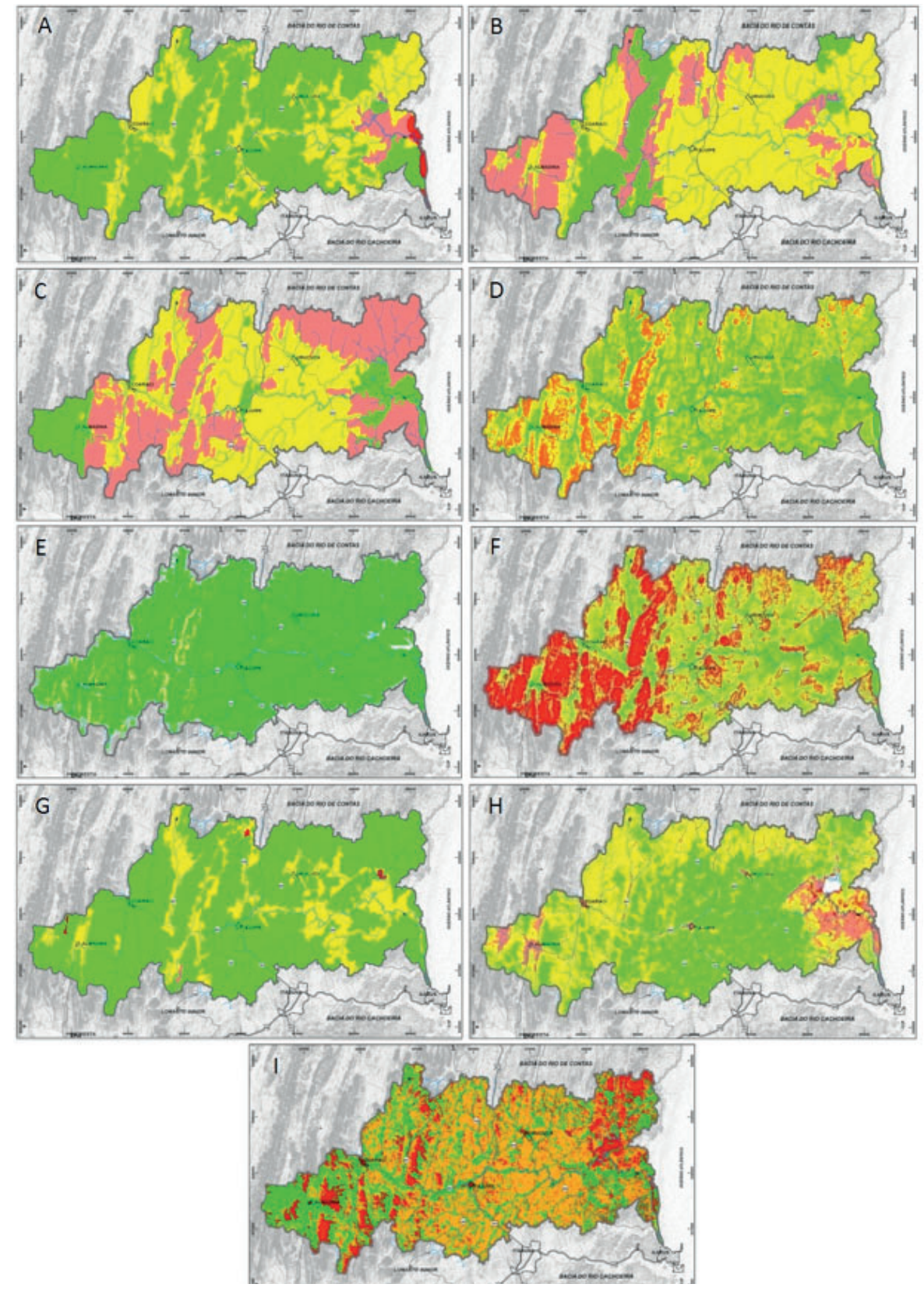

Fonte: elaborado pelos autores.

Nota: os tons coloridos representam as adequabilidades da seguinte forma: verde (favorável), amarela (moderada), laranja (severa) e vermelha/rósea (restritiva). 
A Figura 7 apresenta a Carta de Adequabilidade à Implantação de Obras Lineares na Bacia Hidrográfica do Rio Almada, obtida a partir da interação da adequabilidade dos fatores geotécnico, geomorfológico, geoambiental e de uso e ocupação do solo, conforme a álgebra de mapas definida na equação 1.

Observa-se que a BHRA apresenta uma maior concentração de adequabilidades severas e restritivas nas porçôes oeste, norte e leste. A porção oeste apresenta restriçóes vinculadas à extensa ocorrência de APP (áreas com declividade superior a $45^{\circ}$ e os topos de morros), tais áreas são constituídas por argissolos e mata densa. Já, a porção norte tem suas adequabilidades severa e restritiva controladas pela ocorrência de relevo íngreme e solos argilosos. A porção leste tem a sua adequabilidade severa controlada pela extensa ocorrência de sedimentos inconsolidados arenosos, aliada à presença de nível freático raso e espodossolos, além da existência de APP como áreas úmidas e manguezais e do Parque Estadual da Serra do Conduru.

Em seguida, tendo em vista a avaliação das alternativas de traçado, foi criada uma superfície de atrito com a adaptaçáo dos dados gerados pelo mapa de adequabilidade à implantação de obras lineares. A superfície de atrito estabelece o grau de dificuldade de transposição, ou seja, os custos associados com o movimento através do terreno (trajeto) exercido por valores/pesos impostos às classes de adequabilidade mapeadas. Para a criação da superfície de atrito, utilizou-se a extensão Spatial Analyst do software ArcGIS 9.3, mais especificamente o módulo Cost Distance.

Após a atribuição dos valores de atrito às classes de adequabilidade, com o intuito de evitar que o traçado cruze áreas de qualidade construtiva indesejável, Fforam selecionadas as rotas que cruzam os terrenos mais adequados do ponto de vista geotécnico, geomorfológico, de uso e ocupação do solo e, além disso, interceptando, em casos extremos, áreas de preservação permanente.

A avaliação das rotas de menor atrito, que interligam pontos contidos na BHRA (Figura 8), demonstra o cenário em que o acesso às cidades de Almadina e Coaraci, localizadas na porção oeste da área, deve ter, preferencialmente, suas rotas associadas ao fundo de vale do canal principal do rio Almada, respeitando-se os limites de APP. Na parte leste da bacia, as rotas sugeridas ocorrem, preferencialmente, cruzando terrenos com cobertura de pastagens e evitando a intersecção com áreas úmidas, consideradas de preservação permanente. Tais condiçôes interferem no traçado de acesso pela parte central da bacia, a área 
pleiteada para construção do Complexo Intermodal. Já a parte central da bacia apresenta as melhores alternativas de interligação entre os pontos estudados, principalmente por apresentar relevo, solos e substrato mais favoráveis, além da ocorrência de maior cobertura da cabruca e áreas de pastagens.

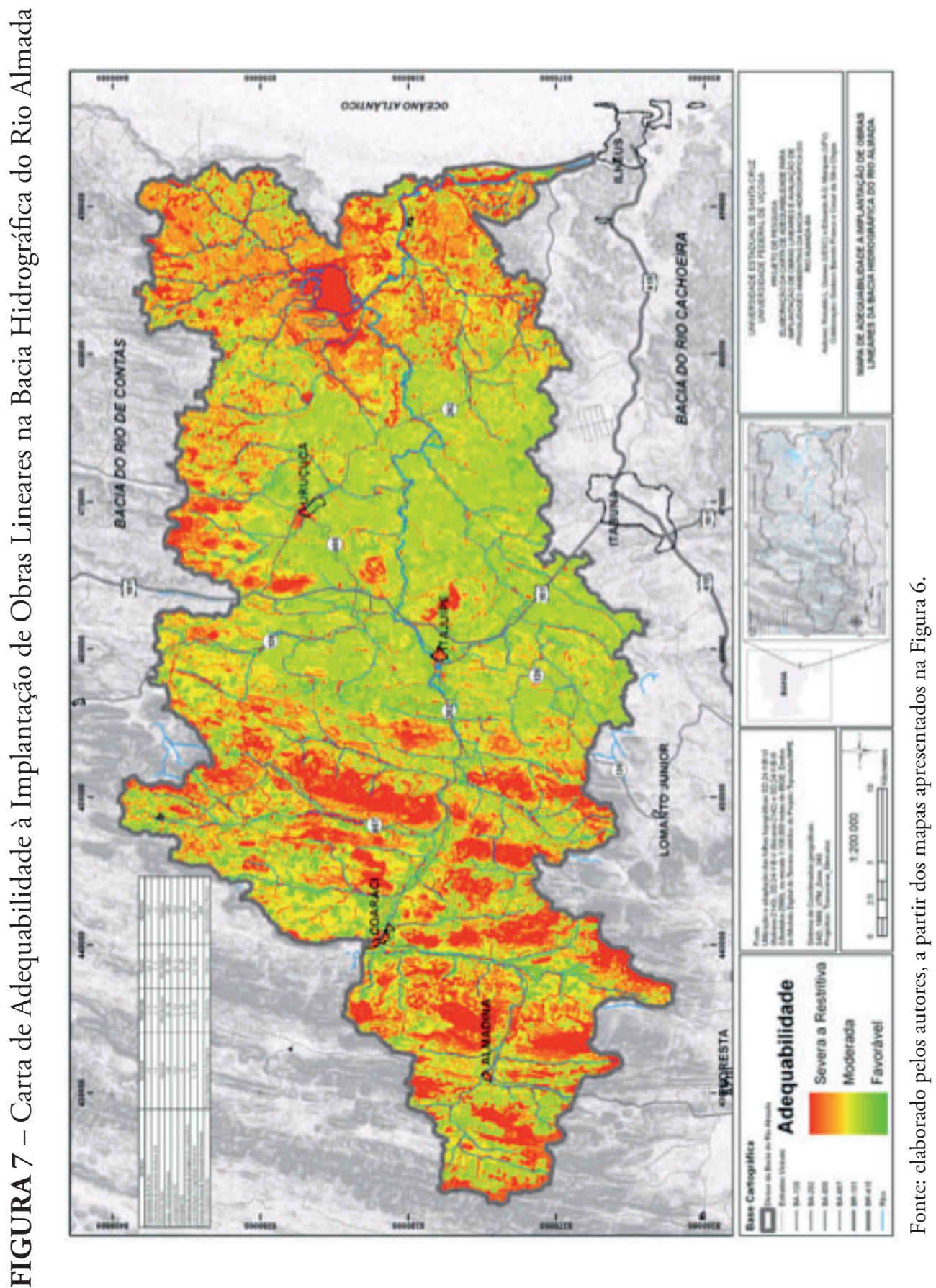




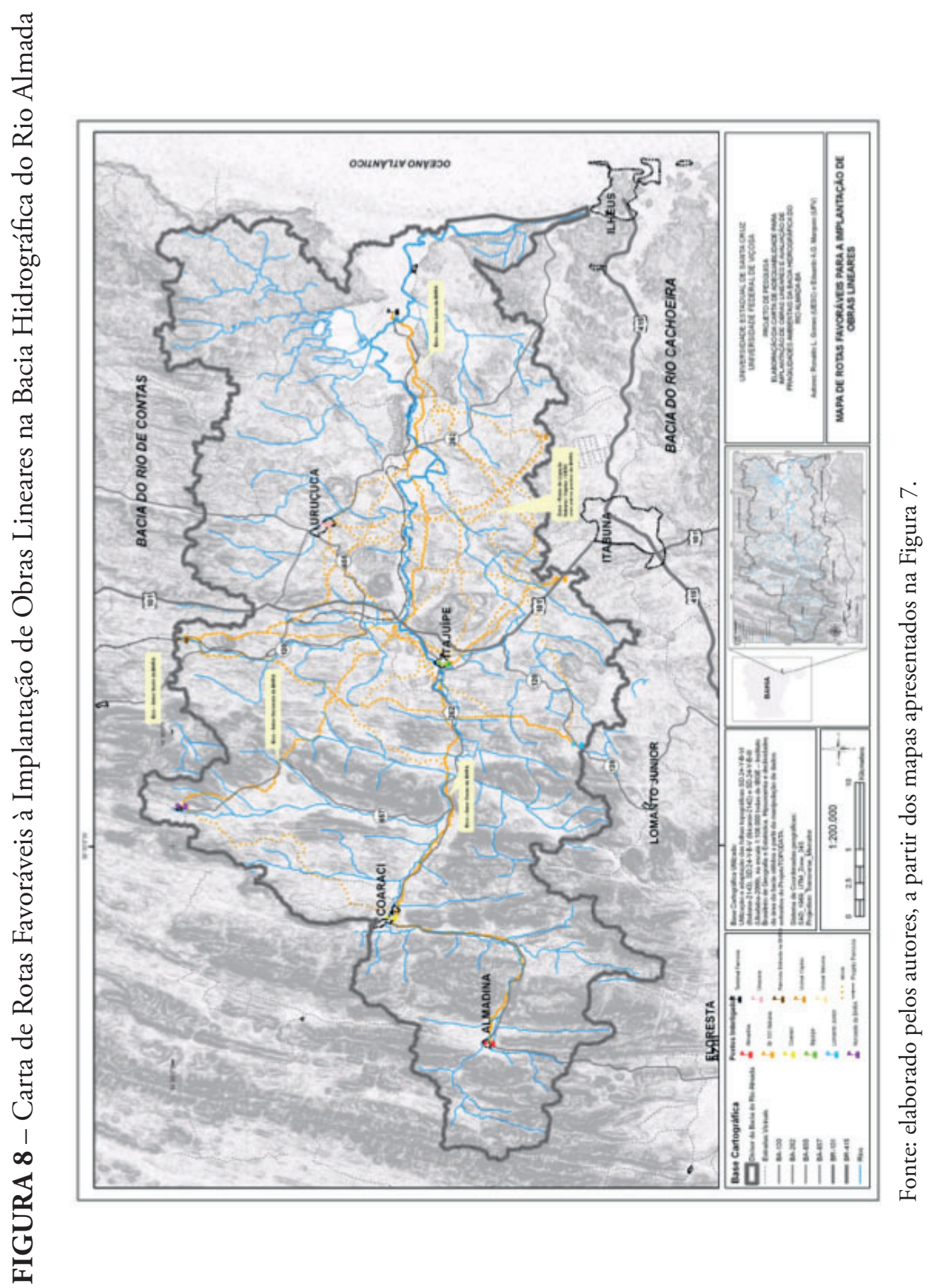




\section{Consideraçóes Finais}

A Carta de Adequabilidade à Implantação de Obras Lineares na Bacia Hidrográfica do Rio Almada foi obtida a partir de aplicação de método baseado nos pressupostos conceituais e aplicação de técnicas de Mapeamento Geotécnico apoiadas em ferramentas de SIG. Tal procedimento, além de utilizar atributos tradicionais associados às características do meio físico, incorporou dados de atributos provenientes das características de uso e ocupação do solo, incluindo dados referentes à aplicação de legislação ambiental a partir do reconhecimento da distribuição de APP na área de estudo. Dessa forma, tornou-se possível a apresentaçáo do panorama de adequabilidades à interveniência de empreendimentos lineares, a exemplo de linhas de transmissão, dutos, rodovias e ferrovias, sob a ótica da análise integrada do meio. Por fim, partindo-se da premissa da importância deste tipo de informação para órgãos públicos, privados e usuários de interesse, ressalta-se algumas limitações e adequaçóes, a exemplo da escala regional a semi-regional $(1: 100.000)$ adotada por este trabalho e a não avaliaçáo de dados construtivos específicos a cada tipo de obra linear. 


\section{Referências}

AKIOSSI, A. et al. Ajuste do traçado de projeto rodoviário a partir da utilização da carta de restrições ambientais. In: CONGRESSO BRASILEIRO DE GEOLOGIA DE ENGENHARIA E AMBIENTAL, 11., 2005, Florianópolis, SC. Anais... Florianópolis, SC, 2005. p. 1-14. v. 1.

AMARANTE, A. et al. Utilização do geoprocessamento no estudo de alternativas de traçado de linhas de transmissão. In: CONGRESSO BRASILEIRO DE GEOLOGIA DE ENGENHARIA E AMBIENTAL, 11, 2005, Florianópolis, SC. Anais... Florianópolis, SC, 2005. p. 1 - 8. v. 1.

ARCANJO, J. B. A. Programa levantamentos geológicos básicos do Brasil. Itabuna. Folha SD.24-Y-B-VI. Estado da Bahia - Escala 1:100.000. Brasília: CPRM, 1997. 276 p.

BARBOSA, T. T. A.; CERRI, L. E. S. Carta geológico-geotécnica para empreendimentos rodoviários a partir de métodos de investigaçáo de superfície, na escala 1:25.000. In: SIMPÓSIO BRASILEIRO DE CARTOGRAFIA GEOTÉCNICA E GEOAMBIENTAL, 5., 2004, São Carlos, SP. Anais... São Carlos, SP: SUPREMA, 2004. p. 1 - 9. v. 1.

CAETANO, N. R.; OHARA, T.; MATTOS, J. T. Mapeamento de propriedades geológicas e geotécnicas do meio físico, a partir de sensoriamento remoto, para planejamento de rodovias. In: CONGRESSO BRASILEIRO DE GEOLOGIA DE ENGENHARIA E AMBIENTAL, 10., 2002, Ouro Preto, MG. Anais... Ouro Preto, MG, 2002. p. 1 -14. v. 1.

CARREGÃ, D.; BALZAN, G. Cartografia geotécnica no planejamento urbano de obras viárias: aplicação ao município de São Paulo. In: SIMPÓSIO BRASILEIRO DE CARTOGRAFIA GEOTÉCNICA, 3., 1998, Florianópolis, SC. Anais... Florianópolis, SC, 1998. p. 1 -18. v. 1.

CORTELETTI, R.; SOBREIRA, F. G. Análise comparativa de impactos ambientais para a concepção de traçados de gasodutos e linhas de transmissão. In: CONGRESSO BRASILEIRO DE GEOLOGIA DE ENGENHARIA E AMBIENTAL, 12., 2008, Porto de Galinhas, PE. Anais... Porto de Galinhas, PE, 2008. p. 1 - 12. v.1.

CREPANI, E. et al. Curso de sensoriamento remoto aplicado ao zoneamento ecológico-econômico. São José dos Campos: INPE, 1996. 
FERES, R.; LORANDI, R. Adequabilidade do terreno de fundo de vale do igarapé Maternidade (Rio Branco-AC) como suporte para obras viárias. In: SIMPÓSIO BRASILEIRO DE CARTOGRAFIA GEOTÉCNICA, 3., 1998, Florianópolis, SC. Anais... Florianópolis, SC, 1998. p. 1 - 11. v. 1.

FIGUEIRA, E. G.; FIGUEIRA, I. F. R.; RODRIGUES, A. C. M. Cartografia geotécnica aplicada a faixas de dutos - emprego de novas geotecnologias em estudo de caso. In: SIMPÓSIO BRASILEIRO DE CARTOGRAFIA GEOTÉCNICA, 7., 2010, Maringá, PR. Anais.... Maringá, PR, 2010. p. 1 -14. v. 1.

FRANCO, G. B. Diagnóstico da fragilidade ambiental e da qualidade da água da bacia do rio Almada, Bahia. 2010. 206 f. Tese (Doutorado em Engenharia Civil - Área de Concentração Geotecnia) - Universidade Federal de Viçosa, Viçosa, 2010.

GOMES, R. L. et al. Implantaçáo do laboratório de análise e planejamento ambiental da UESC. Projeto piloto: avaliaçáo da qualidade ambiental da bacia do rio Almada e área costeira adjacente. Relatório Final. Ilhéus, BA: FAPESB, 2010. 104 p.

GOMES, R. L. Avaliação da fragilidade ambiental e vulnerabilidade natural à perda de solo da bacia hidrográfica do rio Almada. Boletim de Geografia (Online), Maringá, v. 31, n.3, p. 41-53, 2013.

GOMES, R. L. et al. Panorama do uso e ocupação do solo presente nas áreas de preservação permanente da bacia hidrográfica do rio Almada BA. Revista de Geografia, Recife, v. 30, n.3, p. 98-115, 2013.

LÁZARO, A.; MOURA, P. R. M.; MERIGHI, J. Avaliação e gestão de riscos geológico-geotécnicos em obras lineares. In: CONGRESSO BRASILEIRO DE GEOLOGIA DE ENGENHARIA E AMBIENTAL, 11., 2005, Florianópolis, SC. Anais... Florianópolis, SC, 2005. p. 1 -14. v. 1.

MATTOS, J. T.; RUEDA, J. R. T.; SILVA, A. R. Classes de capacidade e suporte do meio físico para o traçado de obras civis lineares, utilizando o processo de análise geoambiental em dados de sensoriamento remoto orbital. In: SIMPÓSIO BRASILEIRO DE CARTOGRAFIA GEOTÉCNICA, 7., 2010, Maringá, PR. Anais... Maringá, PR, 2010. p. 1- 8 . v. 1. 
PACK, R. T.; TARBOTON, D. G.; GOODWIN, C. N. Terrain stability mapping with SINMAP, technical description and users guide for version 1.00. Report Number 4114-0. Salmon Arm, British Columbia, Canadá: Terratech Consulting Ltd., 1998. Disponível em: <http://www. tclbc.com>. Acesso em: 24 jul. 2015.

ROSS, J. L. S. Análise empírica da fragilidade dos ambientes naturais e antropizados. Revista do Departamento de Geografia, São Paulo, v. 8, p. 3-74, 1994.

SILVA, D. M. B.; ZAINE, J. E. Caracterização geológica e geomorfológica como subsídio à implantação de gasodutos. In: CONGRESSO BRASILEIRO DE GEOLOGIA DE ENGENHARIA E AMBIENTAL, 11., 2005, Florianópolis, SC. Anais... Florianópolis, SC, 2005. p. 1 - 8. v. 1.

SILVA, G. S.; GOMES, R. L. Aplicação da técnica de avaliação do terreno e análise da fragilidade ambiental da bacia hidrográfica do rio Almada. Caminhos de Geografia, Uberlândia, v. 11, n. 35, p. 240-259, 2010.

WISCHMEIER, W. H.; SMITH, D. D. Predicting rainfall erosion losses: a guide to conservation planning. Washington, DC: United States Department of Agriculture, 1978. Agriculture Handbook, 537.

ZUQUETTE, L. V. Importância do mapeamento geotécnico no uso e ocupaçáo do meio físico: fundamentos e guia para elaboração. São Carlos, SP. 1993. 2 v. Tese de Livre Docência - Escola de Engenharia de São Carlos, Universidade de São Paulo, São Carlos, 1993. 


\title{
CAPÍTULO 4
}

\section{Zoneamento geohidroecológico da bacia do rio Almada: análise da capacidade de produção de água}

\author{
Danusa Oliveira Campos \\ José Wildes Barbosa dos Santos \\ Edson Vicente da Silva \\ Neylor Alves Calasans Rego
}

\section{Introduçáo}

A água é um recurso natural vital. Tal característica lhe é conferida por proporcionar o equilíbrio dos ecossistemas através da manutenção dos ciclos biogeoquímicos, por ser estratégica ao desenvolvimento agrícola e industrial, por influenciar questóes religiosas e culturais, e ainda por ser um bem social indispensável à adequada qualidade de vida (EGLER, 2012).

A importância da água não impediu a sua degradação. Apesar de ser essencial para a vida, a interferência do homem na natureza, sem conhecer nem respeitar suas limitaçóes, resulta em graves problemas ambientais que afetam diretamente na qualidade e quantidade da água que dispomos. Para reverter ou minimizar este quadro de degradação, é fundamental compreender as relaçóes entre a natureza e a sociedade. Nesse contexto, o planejamento ambiental assume papel primordial no reordenamento territorial fundamentado em práticas sustentáveis. Entre os diversos instrumentos de planejamento, destaca-se o zoneamento ambiental.

O zoneamento ambiental tem sido aplicado a partir de uma abordagem sistêmica, analisando a ordenaçáo do espaço de forma abrangente e integrada e contemplando aspectos econômicos, sociais, físico-territoriais e ecológicos com o intuito de prevenir conflitos pelo uso irracional dos recursos naturais. 
Existem várias metodologias de planejamento ambiental baseadas na análise geossistêmica que está fundamentada na Teoria Geral dos Sistemas, de Bertalanffy (1973). Nessa perspectiva, existem trabalhos com diferentes fundamentaçóes teórico-metodológicas; dentre os quais, destacam-se os trabalhos desenvolvidos por Bertrand (1971), Tricart (1977), Ross (1995), Becker e Egler (1996), Sotchava (1977), e mais recentemente, Rodriguez, Silva e Cavalcanti (2004).

Apesar de esses zoneamentos ambientais serem relevantes para o planejamento da paisagem, os mesmos não foram desenvolvidos com foco na produção de água. Quando o objetivo é zonear com base nos recursos hídricos e seus diferentes enfoques na formação da paisagem, as metodologias citadas apresentam algumas lacunas. Uma delas está no fato dessas metodologias terem sido desenvolvidas para serem aplicadas em qualquer unidade de planejamento (como municípios, por exemplo), podendo ou não ser aplicadas em bacias hidrográficas. Contudo, estudos como a simulação hidrológica, importante para direcionar o planejamento ambiental, só podem ser realizados para bacias hidrográficas. Outro ponto a ressaltar é que, nas metodologias existentes, os recursos hídricos são inseridos como elementos formadores da paisagem, não sendo ponderados os processos físicos que regem a distribuição e o movimento da água na paisagem.

O zoneamento geohidroecológico proposto por Campos (2014) destaca-se por analisar, de forma integrada, as variáveis ambientais, sociais e econômicas, avaliando os processos físicos que regem a distribuição e o movimento da água na paisagem da Bacia Hidrográfica do Rio Almada (BHRA), bem como a sua capacidade de produção de água.

\section{Métodos e Técnicas de Pesquisa}

O método de pesquisa adotado está fundamentado na abordagem sistêmica, integrando análises hidrológicas e a capacidade de produçáo de água da BHRA.

Para o processamento dos dados da bacia e elaboração dos mapas, foi utilizado o Sistema de Informação Geográfica (SIG) ArcGis 9.2 e seus módulos. Os mapas foram trabalhados nas escalas 1: 150.000 e 1: 250.000, utilizando a projeção cartográfica UTM (Universal Transversa de Mercartor) e o Datum SAD69. Ainda foram compilados mapas temáticos da área de estudo, imagens de satélite, imagens de radar, fotografias aéreas e as 
cartas topográficas produzidas pela Superintendência do Desenvolvimento do Nordeste (SUDENE) que abrangem toda área da bacia: Ibicaraí (SD24-Y-B-V), Itabuna (SD-24-Y-B-VI) e Ubaitaba (SD-24-Y-B-III).

A rede de drenagem foi extraída da folha 14_405_SN da imagem de radar TOPODATA, obtida do Banco de Dados Geomorfométricos do Brasil, do Instituto Nacional de Pesquisas Espaciais (INPE) (VALERIANO, 2008).

O contorno da BHRA utilizado neste estudo foi definido por Gomes et al. (2010). Os dados de compartimentação geomorfológica das classes de solos e do uso e ocupação da terra de 2006 foram obtidos do trabalho desenvolvido por Franco (2010).

Os dados das tipologias climáticas foram digitalizados do trabalho de Roeder (1975). Os dados pluviométricos foram extraídos do mapa de pluviosidade da Superintendência de Estudos Econômicos e Sociais da Bahia (SEI, 2003), elaborado com normais climatológicas, do período de 1961 a 1990, do Departamento Nacional de Meteorologia (DNMET).

A evapotranspiraçáo potencial foi obtida do site da Empresa Brasileira de Pesquisa Agropecuária (Embrapa), sendo que os dados foram elaborados pelas normais climatológicas de 1961 a 1990. Foi calculada com os dados adquiridos dos postos do Instituto Nacional de Meteorologia (INMET) situados nos municípios de Ilhéus, Canavieiras, Salvador e Vitória da Conquista; sua distribuição sazonal foi calculada pelo Método das Isoietas, por meio da interpolação de dados das estações pelo Método Ponderação do Inverso das Distâncias (Inverse Distance Weighting - IDW).

O mapa geológico da BHRA foi elaborado com base no Mapeamento Geológico do Quaternário Costeiro da Bahia (MARTIN et al., 1980) e no levantamento geológico elaborado pela Companhia Baiana de Pesquisa Mineral no ano 2000.

O mapa de cobertura vegetal nativa foi obtido de Gouvêa (1976). O mapa hipsométrico foi gerado a partir de dados derivados do Modelo Digital de Terreno, os quais foram adquiridos de imagem TOPODATA (VALERIANO, 2008). Posteriormente, foi elaborado o mapa de declividades, classificado segundo o proposto pela Embrapa (2006).

Para gerar as cartas de Capacidade Natural de Produçáo de Água (CNPA) e Capacidade Ambiental de Produção de Água (CAPA), procedeuse o desenvolvimento de rotinas para a conversão de dados vetoriais em formato matricial para o desenvolvimento das operaçóes de álgebra de mapas. 
A CNPA foi obtida a partir do processamento dos dados que foram rasterizados dos seguintes atributos: pluviosidade, evapotranspiração, geologia, geomorfologia, solo, declividade e vegetação. As classes de CNPA para a BHRA foram estabelecidas conforme apresentado na Tabela 1 .

TABELA 1 - Graus estabelecidos para a capacidade natural de produção de água na Bacia Hidrográfica do Rio Almada

\begin{tabular}{l|c}
\hline $\begin{array}{c}\text { Classes de Capacidade Natural } \\
\text { de Produçáo de Água }\end{array}$ & $\begin{array}{c}\text { Graus de Capacidade Natural } \\
\text { de Produção de Água }\end{array}$ \\
\hline Muito Baixa & $0,0-1,0$ \\
\hline Baixa & $1,0-2,0$ \\
\hline Média & $2,0-3,0$ \\
\hline Alta & $3,0-4,0$ \\
\hline Muito Alta & $4,0-5,0$ \\
\hline
\end{tabular}

Fonte: Campos (2014).

A CNPA foi elaborada a partir de uma adaptação das metodologias propostas por Ross (1995), Crepani et al. (2001) e Costa et al. (2006). Para representar as peculiaridades da área de estudo, foi atribuído um peso geral, variando entre $0 \%$ e 100\% (0 - 1) para cada atributo por meio do Método de Ponderação de Fatores. Isso possibilitou indicar a menor e a maior importância e correlação dos atributos com a produção de água na BHRA, conforme apresentado na Tabela 2.

TABELA 2 - Peso geral atribuído para cada atributo na análise da capacidade natural de produçáo de água na Bacia Hidrográfica do Rio Almada

\begin{tabular}{l|c}
\hline \multicolumn{1}{c|}{ Atributo natural } & Peso geral \\
\hline Pluviosidade & 0,13 \\
\hline Evapotranspiraçáo & 0,13 \\
\hline Geologia & 0,11 \\
\hline Geomorfologia & 0,11 \\
\hline Solos & 0,16 \\
\hline Declividade & 0,16 \\
\hline Vegetaçăo & 0,20 \\
\hline
\end{tabular}

Fonte: Campos (2014).

$\mathrm{Na}$ identificação da CNPA, os pesos gerais e específicos foram definidos com base no arcabouço teórico, trabalhos desenvolvidos na bacia e particularidades da regiáo onde a mesma está inserida. 
Os pesos específicos variaram entre 1 e 5 para cada atributo, diferenciando o grau de importância de cada um deles no que se refere à produção de água na paisagem. Ou seja, quanto maior o peso, maior a sua importância na produção de água. Com os atributos classificados, foi empregada a álgebra de mapas, implementada pela Equação 1:

\section{$\mathrm{CNPA}=\left(\mathrm{Pe}{ }^{*} \mathrm{Pg}\right)+\left(\mathrm{Ee}^{*} \mathrm{Eg}\right)+\left(\mathrm{Ve}^{*} \mathrm{Vg}\right)+\left(\mathrm{Se} \mathrm{Sg}^{*}+\left(\mathrm{Re}^{*} \mathrm{Rg}\right)+\right.$ $\left(\mathrm{De}^{*} \mathrm{Dg}\right)+\left(\mathrm{Gle}^{*} \mathrm{Glg}\right)$}

em que: CNPA = Capacidade Natural de Produção de Água, Pe = Peso Específico da Pluviosidade, Pg $=$ Peso Geral da Pluviosidade, Ee $=$ Peso Específico da Evapotranspiração, Eg = Peso Geral da Evapotranspiração, $\mathrm{Ve}=$ Peso Específico da Vegetação, $\mathrm{Vg}$ = Peso Geral da Vegetação, Se = Peso Específico do Solo, Sg = Peso Geral do Solo, Re = Peso Específico da Geomorfologia, $\mathrm{Rg}=$ Peso Geral da Geomorfologia, $\mathrm{De}=$ Peso Específico da Declividade, $\mathrm{Dg}$ = Peso Geral da Declividade, Gle = Peso Específico da Geologia e Glg = Peso Geral da Geologia.

Para analisar a interferência antrópica na CNPA da BHRA foi elaborado o mapa da Capacidade Ambiental de Produção de Água (CAPA) das suas sub-bacias a partir do processamento dos dados de CNPA e do uso e ocupação do solo. Para tanto, foram atribuídos pesos gerais 0,70 à CNPA e 0,30 ao uso e ocupação do solo. Posteriormente, foi empregada a álgebra de mapas, implementada pela Equação 2:

\section{$\mathrm{CAPA}=\left(\mathrm{CNPA}^{*} \mathrm{Ue}\right)+\left(\mathrm{Ue}^{*} \mathrm{Ug}\right)$}

em que: CAPA = Capacidade Ambiental de Produção de Água; Ue = Peso Específico do Uso e Ocupação do Solo e Ug = Peso Geral do Uso e Ocupação do Solo.

Tal como para a CNPA, os pesos gerais e específicos da CAPA foram definidos com base no arcabouço teórico, trabalhos desenvolvidos na área em estudo e particularidades da região.

A vazão das principais sub-bacias da BHRA foi calculada a partir do modelo hidrológico Soil Moisture Accounting Procedure (SMAP) (LOPES; BRAGA; CONEJO, 1982) em sua versão mensal. Para este cálculo, foram utilizados como dados de entrada a precipitação mensal de seis estaçóes 
pluviométricas (localizadas próximas ou dentro dos limites da bacia), obtida no site da Agência Nacional de Águas (ANA). Os dados de vazão também foram obtidos no site da ANA, e a evapotranspiração calculada foi obtida através do Método de Thornthwaite. Os dados de temperatura utilizados foram fornecidos pela estaçáo meteorológica do Centro de Pesquisa do Cacau (CEPEC) da Comissão Executiva do Plano da Lavoura Cacaueira (CEPLAC).

O zoneamento geohidroecológico foi elaborado a partir da integração dos dados da CAPA das sub-bacias com as características das unidades geossistêmicas e os dados de vazão gerados pelo SMAP. Para chegar a este zoneamento, procede-se o mapeamento e caracterização da capacidade de produção de água das sub-bacias, ponderando-se as potencialidades e limitaçôes das unidades geossistêmicas. As cartas de CNPA e CAPA da BHRA foram produzidas a partir da identificação, mapeamento e caracterização de cada uma das variáveis, classificadas como: Muito Baixa, Baixa, Média, Alta e Muito Alta.

As unidades geossistêmicas da BHRA foram delimitadas a partir de uma análise integrada, tendo como principal critério a geomorfologia, além de levantamentos de campo e outros atributos físico-ambientais: geologia, clima, solos e vegetação.

\section{Identificação das unidades geossistêmicas da bacia do rio Almada}

Foram identificadas cinco Unidades Geossistêmicas (UG) para a BHRA: Cadeias de Serras Altas, Cadeias de Serras Baixas, Depressão Pré-Litorânea, Tabuleiros Úmidos do Almada e Planície Litorânea. O Quadro 1 apresenta uma síntese das limitaçóes e potencialidades de cada uma delas. 
QUADRO 1 - Potencialidades, limitações e problemas ambientais das unidades geossistêmicas da Bacia Hidrográfica do Rio Almada

\begin{tabular}{|c|c|c|}
\hline UG & Potencialidades & Limitaçóes e Problemas Ambientais \\
\hline $\begin{array}{l}\text { Cadeias de } \\
\text { Serras Altas }\end{array}$ & $\begin{array}{l}\text { Ecoturismo, turismo ecológico, } \\
\text { açốes de educação ambiental, } \\
\text { abastecimento de água do } \\
\text { município de Almadina, } \\
\text { patrimônio paisagístico e elevada } \\
\text { biodiversidade. }\end{array}$ & $\begin{array}{l}\text { Assoreamento de rios, avanço de } \\
\text { pastagens, falta de manejo adequado, } \\
\text { caça, desmatamento, ocupação de APP } \\
\text { (Área de Preservação Permanente), } \\
\text { lançamento de esgotos in natura, } \\
\text { disposição de resíduos nos ambientes } \\
\text { naturais, desmatamento, relevo } \\
\text { acidentado com vertentes íngremes, } \\
\text { solos rasos e alta suscetibilidade à erosão. }\end{array}$ \\
\hline $\begin{array}{l}\text { Cadeias de } \\
\text { Serras Baixas }\end{array}$ & $\begin{array}{l}\text { Ecoturismo, turismo ecológico, } \\
\text { açốes de educação ambiental, } \\
\text { abastecimento de água } \\
\text { do município de Coaraci, } \\
\text { patrimônio paisagístico e elevada } \\
\text { biodiversidade. }\end{array}$ & $\begin{array}{l}\text { Lazer e turismo rural, ecoturismo, pesca } \\
\text { artesanal, açóes de educação ambiental, } \\
\text { beleza cênica, expansão urbana } \\
\text { planejada. }\end{array}$ \\
\hline $\begin{array}{l}\text { Depressão } \\
\text { Pré-litorânea }\end{array}$ & $\begin{array}{l}\text { Ecoturismo, turismo } \\
\text { ecológico, açóes de educação } \\
\text { ambiental, abastecimento, } \\
\text { pesca artesanal, patrimônio } \\
\text { paisagístico riquíssimo e elevada } \\
\text { biodiversidade. }\end{array}$ & $\begin{array}{l}\text { Caça ilegal, desmatamento, ocupação } \\
\text { e desmatamento de APP de rios } \\
\text { e nascentes, queimadas, uso de } \\
\text { agrotóxicos, lançamento de esgotos } \\
\text { in natura e disposiçáo de resíduos nos } \\
\text { ambientes naturais. }\end{array}$ \\
\hline UG & Potencialidades & Limitaçóes e Problemas Ambientais \\
\hline $\begin{array}{l}\text { Tabuleiros } \\
\text { Úmidos do } \\
\text { Almada }\end{array}$ & $\begin{array}{l}\text { Turismo planejado, potencial } \\
\text { agrícola expressivo e relevo plano } \\
\text { a suave ondulado. }\end{array}$ & $\begin{array}{l}\text { Ocupaçáo urbana desordenada, presença } \\
\text { de atividades que impactam o lençol } \\
\text { freático, presença de camadas coesas na } \\
\text { subsuperfície dos solos, conversão de } \\
\text { florestas de áreas legalmente protegidas } \\
\text { em outra forma de uso, solos com } \\
\text { baixa capacidade de retençáo de água } \\
\text { e de nutrientes, queimadas, uso de } \\
\text { agrotóxicos, lançamento de esgotos } \\
\text { in natura e disposiçáa de resíduos nos } \\
\text { ambientes naturais. }\end{array}$ \\
\hline $\begin{array}{l}\text { Planícies } \\
\text { Litorâneas } \\
\text { do Almada }\end{array}$ & $\begin{array}{l}\text { Lazer e turismo rural, } \\
\text { ecoturismo, pesca artesanal, } \\
\text { ações de educação ambiental, } \\
\text { beleza cênica, expansáo urbana } \\
\text { planejada. }\end{array}$ & $\begin{array}{l}\text { Ocupação desordenada, ocupação de } \\
\text { APP, erosão decorrente da implantação } \\
\text { do Porto do Malhado, uso de } \\
\text { agrotóxicos, queimadas, lançamento } \\
\text { de esgotos in natura e disposição de } \\
\text { resíduos nos ambientes naturais. }\end{array}$ \\
\hline
\end{tabular}

Fonte: Campos (2014). 


\section{Capacidade natural de produçáo de água da bacia do rio Almada}

A Carta de Capacidade Natural de Produção de Água da Bacia Hidrográfica do Rio Almada (Figura 1) apresenta sub-bacias com igual classe de CNPA. Cada uma das variáveis foi classificada em cinco graus diferenciados de produção de água: Muito Baixa, Baixa, Média, Alta, e Muito Alta.

A ponderação de pesos para a pluviosidade considerou a intensidade de chuva e a distribuição da precipitação durante o ano. A produção de água de uma paisagem está intimamente ligada à quantidade de chuva, pluviosidade total e sua distribuição sazonal. A pluviosidade total evidencia a quantidade de água precipitada disponível. Assim, áreas com alta pluviosidade têm maior probabilidade de infiltraçáo, resultando em alta produção de água.

Os índices pluviométricos na BHRA variam entre 900 e $2.100 \mathrm{~mm}$, aumentando no sentido oeste-leste (SEI, 2003). Enquanto as áreas mais próximas do litoral apresentam chuvas constantes e regulares, as áreas a oeste caracterizam-se por períodos de invernos mais secos. Assim, as áreas que apresentaram pluviosidade acima de $2.000 \mathrm{~mm}$ e distribuição constante das chuvas durante todos os meses foram classificadas com CNPA Muito Alta. As paisagens com precipitações entre 1.600 e 1.999 mm, distribuídas igualmente durante o ano, foram consideradas com Alta CNPA; áreas com índices pluviométricos entre 1.000 e $1.500 \mathrm{~mm}$, distribuídos de forma desigual durante o ano, foram classificadas com Média CNPA. E áreas com índices pluviométricos anuais abaixo de $1.000 \mathrm{~mm}$, distribuídos de forma desigual, foram consideradas com Baixa CNPA.

O cálculo da CNPA para pluviosidade evidencia que mais de $90 \%$ da BHRA apresenta Média ou Alta CNPA; e menos de 10\%, Baixa ou Muito Alta CNPA. Nenhuma área da bacia apresentou forte intensidade pluviométrica com estação seca marcante; não havendo, portanto, áreas classificadas com Muito Baixa CNPA para pluviosidade.

A análise da CNPA para evapotranspiração foi baseada na capacidade evapotranspirativa da bacia, sendo que quanto maior for o índice de evapotranspiração, menor será a quantidade de água disponível e a vazão dos rios e, consequentemente, menor será a produção de água na paisagem. Os índices de evapotranspiração na BHRA variam no sentido oeste-leste de 924 a $1.300 \mathrm{~mm}$. Assim, as classes de CNPA para a evapotranspiração variaram de Baixa a Alta CNPA no sentido leste-oeste. 


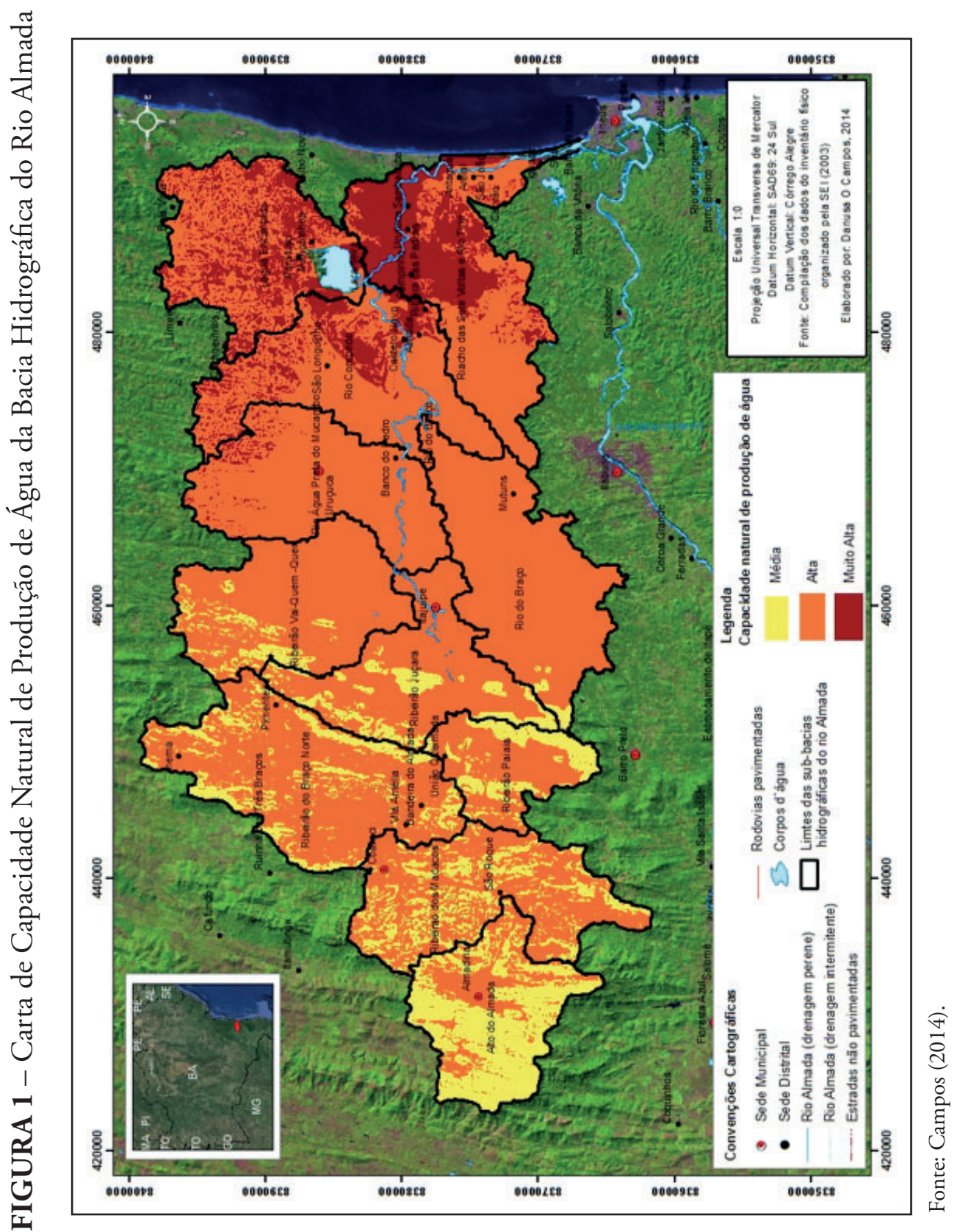

A análise da CNPA para a geologia considerou a composição mineralógica, o grau de coesão das rochas e a presença de estruturas (falhas e zonas de cisalhamento) que favorecem a produção de água. A presença de estruturas como falhas e fraturas encontradas em rochas cristalinas favorece o processo de infiltração, assim como materiais porosos e permeáveis, sedimentos arenosos, rochas sedimentares e cristalinas muito fraturadas ou porosas. 
Já rochas argilosas e rochas cristalinas pouco fraturadas dificultam o referido processo.

Nesse contexto, as rochas das unidades Pré-Cambrianas do Domínio Coaraci-Itabuna possuem um forte grau de coesão com a presença de falhas e zonas de cisalhamento nas porçóes oeste e leste da BHRA. Como essas rochas dificultam a infiltração das águas, provocando o escoamento superficial, as áreas com tais características geológicas foram classificadas com Baixa CNPA.

As coberturas sedimentares do Grupo Barreiras apresentam situação intermediária, visto que apresentam horizontes argilosos e síltico-argilosos intercalados por horizontes arenosos e areno-conglomeráticos mais espessos. Assim sendo, suas respectivas áreas foram classificadas com Média CNPA.

Já os Terraços Marinhos Holocênicos são formados por solos arenosos, com alta porosidade e permeabilidade. Assim, às áreas dos Depósitos Sedimentares do Quaternário foi atribuída a classe Muito Alta CNPA; e aos Depósitos Flúvio-Lagunares argilosos, a classe Alta CNPA.

A porosidade do solo vai regular a quantidade de água absorvida. De tal modo que, em solos arenosos, a absorção da água é mais rápida, havendo pouca retenção por causa do predomínio dos macroporos. Já em solos argilosos, existe maior retenção de água por haver maior agregação das partículas; ou seja, devido aos microporos, a absorção da água é mais demorada (LOPES; BRAGA; CONEJO, 1982). A análise da CNPA associada aos solos mostrou que, para os mais arenosos, a classificaçáo variou de Muito Alta a Alta CNPA. Os solos argilo-arenosos ou areno-argilosos foram classificados de Média CNPA, e aos solos argilosos foram atribuídas as classes Baixa ou Muito Baixa CNPA.

As classes de CNPA para a geomorfologia foram estabelecidas em função das formas do relevo. As Serras e Maciços Pré-Litorâneos foram classificadas com Baixa CNPA, pois, em relevo forte ondulado e montanhoso, as águas pluviais fluem mais rapidamente para os canais fluviais. A Depressão Itabuna-Itapetinga apresentou Alta CNPA, pois tal formação geológica favorece o acúmulo das águas e a deposição do material transportado pelos rios. Deste modo, há maior possibilidade de inundações.

Os Tabuleiros Pré-Litorâneos e Tabuleiros Pré-Litorâneos-Bacia são caracterizados por relevo de morros e colinas, associados às litologias sedimentares que vão do plano ao ondulado, apresentando Alta CNPA. E aos 
terrenos dos Depósitos Sedimentares Quaternários, por apresentarem áreas planas, onde o escoamento superficial é lento, foi atribuída a classe Muito Alta CNPA.

A vegetação é um componente da natureza que contribui de forma ímpar para a produção de água devido à sua função reguladora dos fluxos de água. Ela controla o escoamento superficial, proporciona a recarga natural dos aquíferos (MOTA, 1995) e favorece a infiltração da água, de modo a impedir a compactação do solo. A vegetaçáo nativa da BHRA foi classificada com Média CNPA quanto às Formações Edáficas, Muito Alta CNPA nas áreas de Mata Higrófila e Alta CNPA para a Mata Mesohigrófila.

As paisagens que compóem a BHRA obtiveram graus de CNPA que variaram entre 2,5 e 4,8 e foram divididas da seguinte forma: Média CNPA (14,04\%), Alta CNPA (74,25\%) e Muito Alta CNPA (11,71\%), de acordo com aTabela 3.

\section{Capacidade ambiental de produçáo de água da bacia do rio Almada}

A CAPA da BHRA representa o cruzamento entre os dados da CNPA e do uso e ocupação do solo. Este cruzamento resultou na classificação da BHRA em quatro classes, apresentadas na Tabela 3 e espacializadas na Figura 2. É importante ressaltar que, apesar da forte pressão antrópica, a BHRA não apresentou nenhuma área classificada com Muito Baixa CNPA. A Tabela 3 apresenta as áreas em que a interferência antrópica alterou significativamente a CNPA das paisagens. 
TABELA 3 - Classes e áreas estabelecidas para a capacidade natural e ambiental de produção de água na Bacia Hidrográfica do Rio Almada

\begin{tabular}{|c|c|c|c|}
\hline \multicolumn{2}{|c|}{$\begin{array}{l}\text { Capacidade Natural de } \\
\text { Produçáo de Água }\end{array}$} & \multicolumn{2}{|c|}{$\begin{array}{l}\text { Capacidade Ambiental de } \\
\text { Produçáo de Água }\end{array}$} \\
\hline Classe & Área (\%) & Classe & Área (\%) \\
\hline \multirow{2}{*}{ Média } & \multirow{2}{*}{14,04} & Baixa & 1,54 \\
\hline & & Média & 12,50 \\
\hline \multirow{3}{*}{ Alta } & \multirow{3}{*}{74,25} & Baixa & 0,06 \\
\hline & & Média & 57,37 \\
\hline & & Alta & 16,82 \\
\hline \multirow{3}{*}{ Muito Alta } & \multirow{3}{*}{11,71} & Média & 3,87 \\
\hline & & Alta & 7,38 \\
\hline & & Muito Alta & 0,46 \\
\hline
\end{tabular}

Fonte: Campos (2014).

As áreas de Baixa CAPA encontram-se na parte oeste da BHRA e nos vales fluviais do ribeirão Papaia, próximos à Serra dos Mutuns. Ocupam 1,60\% da bacia nas áreas onde predominam os relevos movimentados das Serras e Maciços Pré-Litorâneos. O uso e ocupação do solo predominante é pasto ou solo exposto em relevo movimentado. Mas há também a presença de pequenos fragmentos de cabruca. As atividades econômicas principais são a pecuária e cultivos tradicionais de subsistência, como feijão e mandioca, nos vales fluviais.

As áreas de Média CAPA ocupam 73,85\% de toda a bacia nas porçôes onde são encontrados: solos pouco desenvolvidos do relevo movimentado das Serras e Maciços Pré-litorâneos; argissolos vermelho-amarelo e latossolos vermelho-amarelo do Domínio Depressão Itabuna-Itapetinga; os Tabuleiros Úmidos e os solos jovens dos Depósitos Sedimentares do Quaternário. Nesta área, grande parte da floresta foi convertida, principalmente, em cabruca, solo exposto, pasto para criaçáo de gado e policulturas permanentes cultivadas quase sempre nos vales fluviais, como banana, cacau, borracha, café, coco-da-baía, dendê, laranja, mamão, maracujá, palmito, pimenta-do-reino e borracha; lavouras temporárias de abacaxi, canade-açúcar, feijão, mandioca e milho.

As áreas classificadas com Alta CAPA correspondem a 74,20\% da BHRA, englobando as Cadeias de Serras Baixas. Distribuem-se em pequenas manchas por toda a Depressão Pé-Litorânea e nos Tabuleiros Úmidos do Almada. Nas Planícies Litorâneas, as áreas com Alta CAP correspondem a 68\% dessa classe 
que também é formada por remanescentes da Mata Atlântica resguardados pelo Parque Estadual Serra do Conduru, além de pastagens e agricultura permanente, como a do cacau, e agricultura temporária, como mandioca, banana, coco-da-baía e abacaxi. A particularidade desta classe é que as áreas ao norte do extremo leste da BHRA são protegidas por unidades de conservação; e aquelas ao sul, ocupadas por parte da área urbana de Ilhéus.

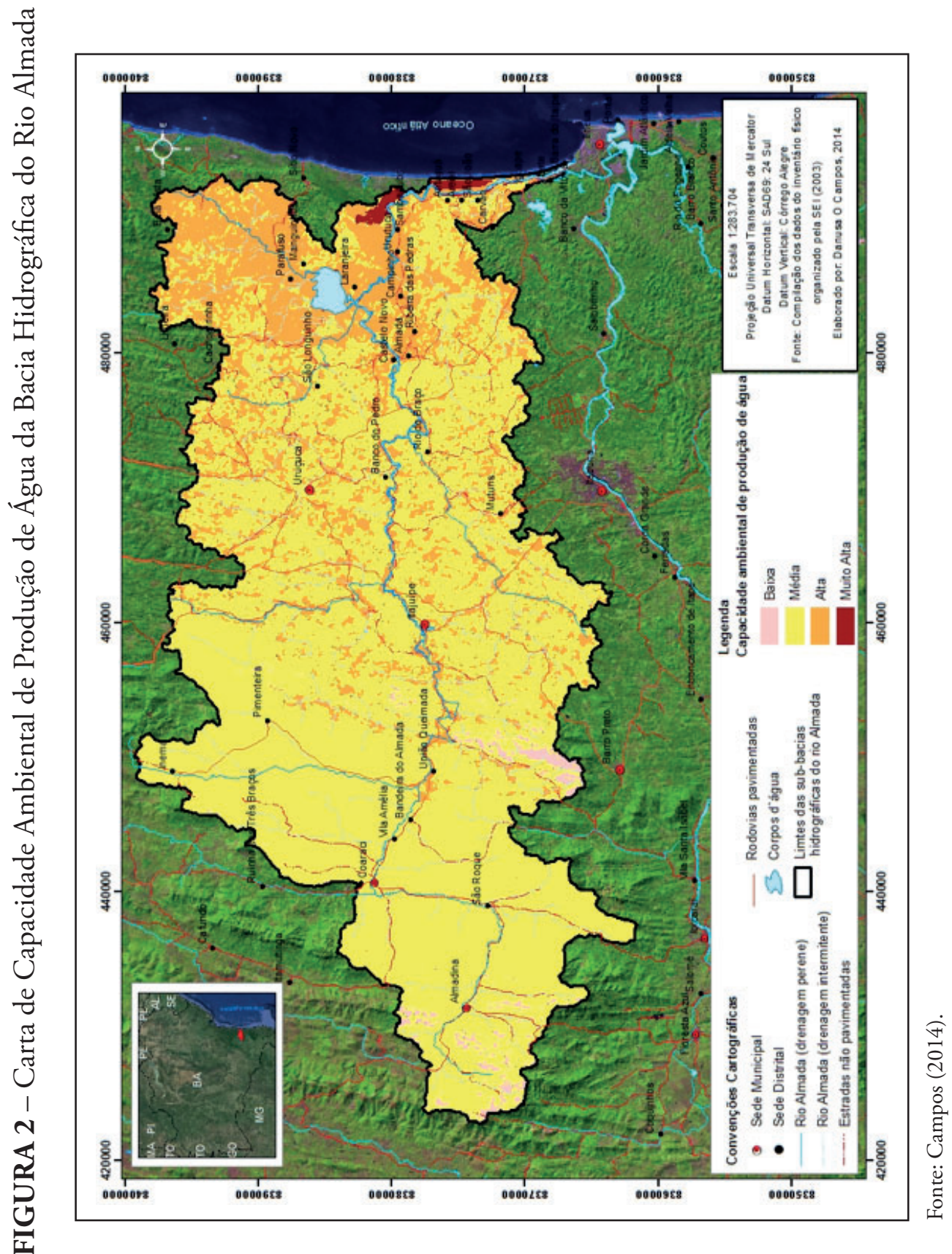


As áreas de Muito Alta CAPA abrangem apenas $0,46 \%$ de toda a bacia. Esta classe aparece no baixo curso do rio Almada, nos Tabuleiros Úmidos do Almada, nas bordas da Lagoa Encantada e no extremo leste da bacia nos Depósitos Sedimentares do Quaternário. Apesar de possuir Muito Alta CAPA, tais áreas estão sob forte pressão antrópica.

\section{Simulaçáo hidrológica da bacia do rio Almada}

A escolha do modelo hidrológico para aplicar a simulaçáo tomou como referência a facilidade de execuçáo do programa e os dados de entrada. O SMAP mostrou-se como um modelo simples para estimar a vazão das sub-bacias da BHRA, requerendo apenas os dados de precipitaçáo, a vazão de um posto fluviométrico localizado dentro da bacia (vazão observada), dados de evapotranspiração e a área das sub-bacias.

Para obter a vazão das sub-bacias da BHRA, foram utilizadas séries históricas de 2000 a 2012 em todos os dados de precipitação, evapotranspiração e vazão. A determinação da série histórica deu-se em função da disponibilidade dos dados fluviométricos. Para os dados de precipitação mensal, foram utilizadas seis estaçóes pluviométricas da ANA (Coaraci, Floresta Azul, Ibicaraí, Itajuípe-Piranji, Barro Preto e Uruçuca).

Para a homogeneização dos dados pluviométricos das estaçóes, foram preenchidas as falhas, aplicando-se o Método da Ponderação Regional da Organização das Naçóes Unidas para a Educação, a Ciência e a Cultura (UNESCO). Posteriormente, foi delimitada a área de influência de cada posto pluviométrico, conforme o Método de Thiessen.

Devido à inexistência de estações evaporimétricas com abrangência de toda a área de estudo, os dados de evapotranspiração potencial foram calculados utilizando os dados de temperatura da estação climatológica do CEPEC/CEPLAC, através do Método de Thornthwaite. Os dados fluviométricos foram obtidos do posto fluviométrico Provisão II, localizado próximo à foz do rio Almada.

O comportamento hidrológico médio da vazão na seção de Provisão II evidencia que o pico de vazão acontece no mês de abril. A partir de entáo, até o mês de setembro, há um decaimento do escoamento. E as vazóes com valores mais baixos podem ser verificadas no mês de outubro. Os dados de vazão, precipitação e evapotranspiração foram integrados no SMAP, iniciando pelo ano hidrológico da BHRA, que começa em setembro e termina em agosto. 
A fase da calibração visa a determinação dos valores dos parâmetros do modelo. Neste trabalho, a calibraçáo foi realizada por tentativa-erro, portanto foram examinados distintos conjuntos de parâmetros até se alcançar um vetor de parâmetros que pudesse representar a resposta natural da bacia àquela precipitação. Esse método está condicionado à experiência do usuário. Portanto, é a correta interpretação dos parâmetros que conduz mais rapidamente a valores que correspondem à requerida precisão.

A calibraçáo foi realizada em toda a BHRA de maneira convencional (LOPES, 1999). O período de dados usado para a calibraçáo da BHRA compreende de setembro de 2000 a agosto de 2005, e o período dos dados para a validação foi de setembro de 2005 a agosto de 2012. Os períodos selecionados corroboram Lopes (1999) na medida em que este pesquisador indica um período para calibração mensal de 2 a 9 anos.

A qualidade do ajuste de calibração seguiu a observação da aderência da vazáo calculada à vazão observada, coeficiente de correlaçáo linear de Pearson (R2), coeficiente de determinação (R2) e o índice de eficiência de Nash e Sutcliffe. A validação das vazóes obtidas pela calibração obteve valores altos de correlação linear de 0,90, o coeficiente de determinação 0,78 e o coeficiente de Nasch 0,90, apresentando, portanto, bons resultados finais da calibraçáo. Collischonn (2001) ressalta que a representatividade do modelo é considerada adequada para valores de Nasch superiores a 0,75.

Após a validação dos parâmetros utilizados na calibração, foi realizada a simulação da vazão de cada uma das 11 sub-bacias da BHRA, usando o período de setembro de 2006 a agosto de 2012. As vazóes obtidas das sub-bacias evidenciaram uma produção de água menor nas sub-bacias Alto do Almada (1,91 m3/s) e ribeirão Papaia $(1,08 \mathrm{~m} 3 / \mathrm{s})$, localizadas no alto curso do rio Almada, e maiores vazóes nas demais sub-bacias, com destaque para ribeirão do Braço Norte e rio do Braço, ambas com uma vazáo de $2,95 \mathrm{~m} 3 / \mathrm{s}$.

\section{Zoneamento geohidroecológico da bacia do rio Almada}

A Carta de Zoneamento Geohidroecológico da Bacia Hidrográfica do Rio Almada foi elaborada com base na capacidade ambiental de produção de água das suas sub-bacias, resultando nas classes espacializadas na Figura 3. As vazóes estimadas pelo SMAP das sub-bacias corroboram os resultados obtidos para a CAPA. 


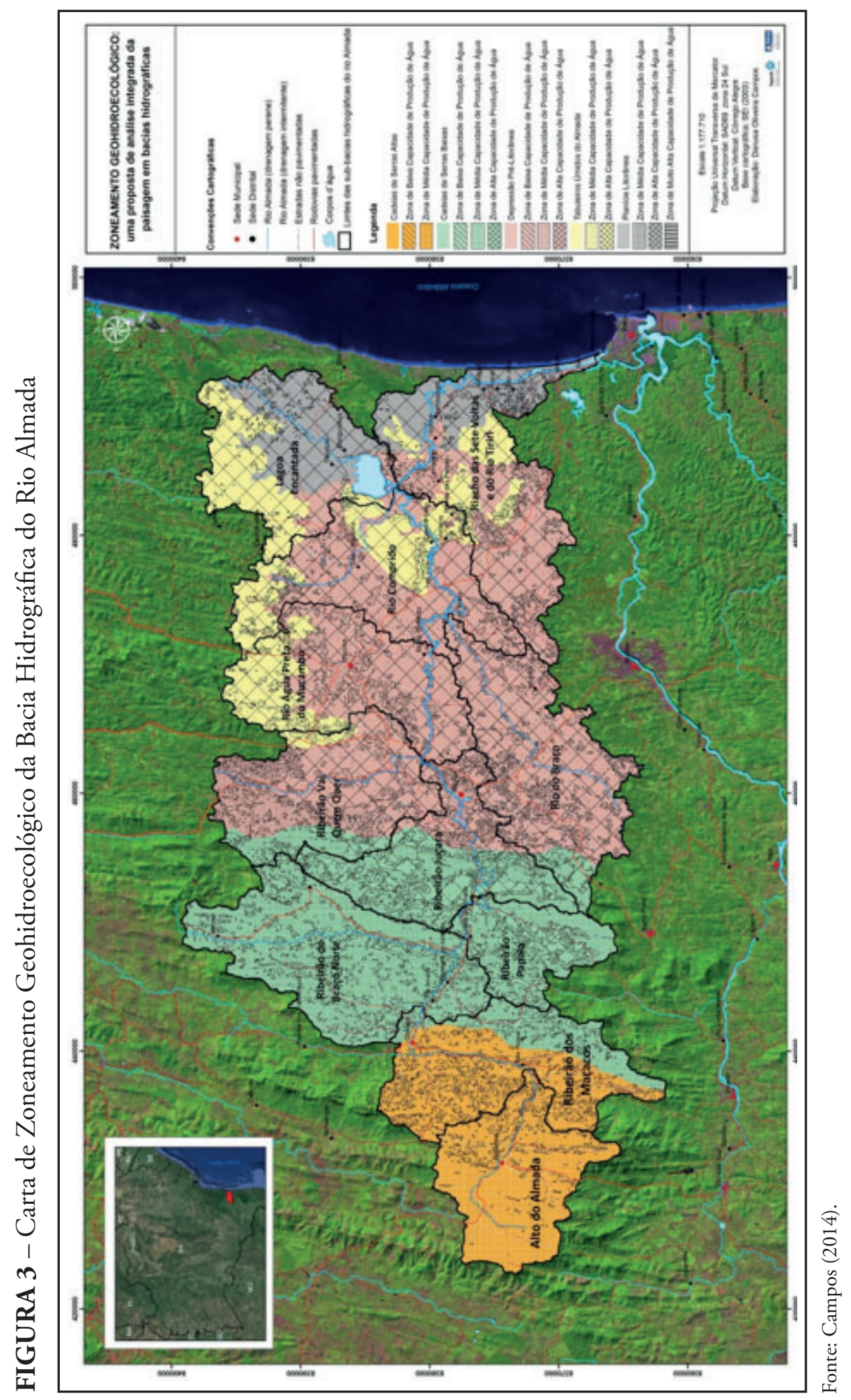


A sub-bacia do Alto do Almada, localizada na UG Cadeias de Serras Altas, tinha 67\% de suas terras classificadas com Média CNPA; contudo, com a interferência antrópica através da conversão do uso do solo de floresta para pasto e solo exposto em uma paisagem composta por solos pouco desenvolvidos em relevo movimentado e com declividade acentuada, houve uma perda da aptidão para a produção de água das paisagens, passando para a classe Baixa CAPA mais de $90 \%$ da sua área.

A sub-bacia do ribeirão Papaia apresenta uma paisagem semelhante à sub-bacia do Alto do Almada, caracterizada pela UG Cadeias de Serras Baixas, com áreas classificadas com Média CNPA (67\%) e Alta CNPA (33\%). Após a conversão do uso e ocupaçáo do solo, 78\% da área passou a ser classificada com Média CAPA e 12\% com Baixa CAPA.

As sub-bacias dos ribeiróes Braço e Braço Norte e dos rios Tiriri e Sete Voltas apresentaram as maiores vazões por possuírem as maiores áreas dentro da bacia e por estarem cobertas por vegetação nativa e cabruca.

Apesar de apresentarem paisagens distintas com substratos rochosos e solos diversificados, os resultados evidenciam que as sub-bacias não apresentaram uma variação significativa quanto aos valores de vazão. Este fato é apoiado pelos dados qualitativos gerados pela CAPA que exibem $73 \%$ de toda a área da BHRA como Média, classificação atribuída à cobertura vegetal de mata e cabruca. A proteçáo exercida pelos remanescentes de mata e cabruca é evidenciada na ausência de vegetação em áreas qualificadas com CAPA Muito Baixa nesta bacia hidrográfica.

\section{Comentários Finais}

Os resultados aqui apresentados demonstram que a bacia do rio Almada apresenta, de modo geral, boa capacidade para a produção de água, o que ressalta a sua importância ecológica, econômica e social para a regiáo onde está inserida. A capacidade natural de produção de água alcançou graus que variaram entre 2,5 a 4,8; logo, as paisagens foram classificadas com Média, Alta e Muito Alta capacidade, abrangendo, respectivamente, cerca de $14,04 \% 74,25 \%$ e $11,71 \%$ da área da bacia .

As vazões calculadas para as 11 sub-bacias evidenciaram uma produção de água menor nas sub-bacias do Alto do Almada $\left(1,91 \mathrm{~m}^{3} / \mathrm{s}\right)$ e ribeirão Papaia $\left(1,08 \mathrm{~m}^{3} / \mathrm{s}\right)$, enquanto que as maiores vazóes foram observadas nas sub-bacias do ribeirão do Braço Norte, ribeirão do Braço, rio Sete Voltas e rio Tiriri. 
O zoneamento geohidroecológico da bacia do rio Almada mostrou que os resultados obtidos com o emprego do SMAP corroboraram os resultados de capacidade ambiental de produção de água.

Considera-se que o método aqui apresentado representa uma importante ferramenta de análise da paisagem voltada para a gestão ambiental sustentável de bacias hidrográficas, contemplando de forma integrada os diferentes enfoques da água na paisagem. E por fim, acredita-se que este método pode e deve ser replicado em outras bacias, necessitando apenas de uma adequação dos pesos às características ambientais da bacia a ser analisada. 


\section{Referências}

BECKER, B. K.; EGLER, C. A. Detalhamento da metodologia para execuçáo do zoneamento ecológico-econômico pelos Estados da Amazônia Legal. Brasília, DF: Secretaria de Assuntos Estratégicos (SAE)/Ministério do Meio Ambiente (MMA), 1996.

BERTALANFFY, L. V. Teoria geral dos sistemas. Petrópolis, RJ: Vozes, 1973.

BERTRAND, G. Paisagem e geografia física global. Esboço metodológico. Caderno de Ciências da Terra, São Paulo, n. 13, p. 1-17, 1971.

CAMPOS, D. O. Zoneamento geohidroecológico: uma proposta de análise integrada da paisagem em bacias hidrográficas. 2014. $181 \mathrm{f}$. Tese (Doutorado em Desenvolvimento e Meio Ambiente) - Universidade Estadual de Santa Cruz, Ilhéus, BA, 2014.

COLLISCHONN, W. Simulaçáo hidrológica de grandes bacias. 2001. $182 \mathrm{f}$. Tese (Doutorado em Engenharia de Recursos Hídricos e Saneamento Ambiental) - Instituto de Pesquisas Hidráulicas, Universidade Federal do Rio Grande do Sul, Porto Alegre, 2001.

COSTA, F. H. S. et al. Determinação da vulnerabilidade ambiental na bacia potiguar, região de Macau ( $\mathrm{RN})$, utilizando sistemas de informações geográficas. Revista Brasileira de Cartografia, v. 58, n. 2, p. 119$127,2006$.

CREPANI, E. et al. Sensoriamento remoto e geoprocessamento aplicados ao zoneamento ecológico-econômico e ao ordenamento territorial. São José dos Campos, SP: INPE, 2001.

EGLER, M. Gerenciamento integrado de recursos hídricos no Estado do Rio Janeiro: ensaio de indicador para o estabelecimento da avaliação das relaçóes entre qualidade da água e cobertura vegetal. 2012. 315 f. Tese (Doutorado em Planejamento Energético) - Universidade Federal do Rio de Janeiro, Rio de Janeiro, 2012.

EMPRESA BRASILEIRA DE PESQUISA AGROPECUÁRIA - EMBRAPA. Sistema brasileiro de classificaçáo de solos. 2. ed. Brasília, DF: Centro Nacional de Pesquisas de Solos/EMBRAPA, 2006. 
FRANCO, G. B. Fragilidade ambiental e qualidade da água na bacia do rio Almada - Bahia. 2010. 217 f. Tese (Doutorado em Engenharia Civil) - Universidade Federal de Viçosa, Viçosa (MG), 2010.

GOMES, R. L. et al. Implantação do laboratório de análise e planejamento ambiental da UESC. Projeto piloto: avaliaçáo da qualidade ambiental da bacia do rio Almada e área costeira adjacente. Relatório Final. Ilhéus, BA: FAPESB, 2010. 104 p.

GOUVÊA, J. B. S. Recursos Florestais. Rio de Janeiro: Cartográfica Cruzeiro do Sul,1976. (Diagnóstico socio-econômico da regiáo cacaueira).

LOPES, J. E. G.; BRAGA, B. P. F.; CONEJO, J. G. L. SMAP - A Simplified Hydrological Model, Applied Modelling in Catchment Hydrology. Washington: Water Resources Publications, 1982.

LOPES, J. E. G. Manual do programa de simulação hidrológica SMAP. 1999. 19 p. (Cedido pelo autor).

MARTIN, L. et al. Mapa geológico do quaternário costeiro do Estado da Bahia. Texto explicativo. Salvador: Secretária de Minas e Energia/Coordenação de Produção Mineral, 1980.

MOTA, S. Preservaçáo e conservaçáo de recursos hídricos. 2. ed. Rio de Janeiro: ABES, 1995.

RODRIGUEZ, J. M. M.; SILVA, E. V.; CAVALCANTI, A. P. B. Geoecologia das paisagens: visão geossistêmica da análise ambiental. Fortaleza: Editora UFC, 2004.

ROEDER, M. Reconhecimento climatológico. Diagnóstico sócio-econômico da regiáo cacaueira. Rio de Janeiro: Cartografia Cruzeiro do Sul, 1975.

ROSS, J. L. S. Análise e síntese da abordagem geográfica da pesquisa para o planejamento ambiental. Revista do Departamento de Geografia, São Paulo, v. 9, p. 65 - 75, 1995.

SOTCHAVA, V. B. O estudo de geossistemas (Métodos em questão, 16). São Paulo: Instituto de Geografia - USP, 1977.51 p. 
SUPERINTENDÊNCIA DE ESTUDOS ECONÔMICOS E SOCIAIS DA BAHIA - SEI. Base cartográfica digital. Salvador: SEI, 2003. 10 CD-ROM. ISBN 85-240-3169-7. (obra completa).

TRICART, J. Ecodinâmica. Rio de Janeiro: IBGE, 1977.

VALERIANO, M. M. TOPODATA: guia para utilização de dados geomorfológicos locais. Sáo José dos Campos, SP: INPE-15318-RPQ/818, 2008. 


\title{
Bacia do rio Buranhém: análise integrada da paisagem
}

\author{
Dayse Gomes de Azevedo \\ Ronaldo Lima Gomes \\ Maria Eugênia Bruck de Moraes
}

\section{Introdução}

A Ecologia da Paisagem como estudo interdisciplinar que envolve conceitos de Geografia e Ecologia tem se firmado por sua abordagem integradora e flexível. Ela desenvolveu-se, sobretudo, a partir da segunda metade do século XX com o objetivo de fornecer uma base científica para o planejamento, manejo, desenvolvimento e conservação das paisagens (NUCCI, 2007). Nessa perspectiva, o conceito de paisagem, que tem evoluído desde seu surgimento, pode ser definido como "um mosaico heterogêneo formado por unidades interativas; sendo essa heterogeneidade existente para pelo menos um fator, segundo um observador e numa determinada escala" (METZGER, 2001, p. 4).

Forman e Godron (1986) afirmam que o estudo da paisagem deve considerar suas três características principais: a estrutura, formada por um elemento dominante denominado "matriz", por "corredores" e "manchas"; a função que trata da interação entre seus elementos; e a dinâmica que consiste nas alteraçóes que ocorrem ao longo do tempo.

A escolha de uma bacia hidrográfica como paisagem a ser estudada tem a vantagem de ser uma unidade não arbitrária, com limites bem definidos e que reflete os efeitos que decorrem das atividades antrópicas na área (LANNA, 1997).

A bacia hidrográfica pode ser abordada como uma unidade ecossistêmica, composta por elementos bióticos e abióticos que se inter-relacionam 
em fluxo contínuo. A fragmentação de sua cobertura vegetal é um dos principais efeitos antrópicos, pois desequilibra sua estrutura e funcionamento na medida em que altera os seus processos ecológicos. A intensificação de processos erosivos implica no assoreamento de corpos d'água, o que por sua vez acaba prejudicando a qualidade da água.

A bacia do rio Buranhém destaca-se como um dos polos de desenvolvimento do estado da Bahia, abrangendo áreas de municípios como Guaratinga, Eunápolis e Porto Seguro. Os remanescentes florestais que compóem a bacia vêm sofrendo considerável degradação ambiental devido à substituiçấo da cobertura vegetal original por monoculturas e pastagens (AZEVEDO, 2014).

Considerando que a aplicação dos princípios da Ecologia da Paisagem é fundamental para o entendimento do processo de fragmentação, este capítulo tem o propósito de apresentar uma análise da estrutura da paisagem da bacia do rio Buranhém, visando identificar áreas prioritárias para a restauraçáo florestal.

\section{Caracterização da bacia do rio Buranhém}

A bacia do rio Buranhém possui área de $2.504,83 \mathrm{~km}^{2}$ e está localizada entre o extremo sul do estado da Bahia e o leste de Minas Gerais, onde se encontram suas principais nascentes; mais precisamente no município mineiro de Santo Antônio do Jacinto, na Serra dos Aimorés. Essa bacia confronta-se a oeste e ao norte, com a bacia do rio Jequitinhonha; ao norte, com as bacias dos rios João de Tiba e dos Mangues; ao sul, com as bacias dos rios Jucuruçu, Caraíva e do Frade e a leste, com o Oceano Atlântico (Figura 1). O rio Buranhém, também conhecido como rio do Peixe, percorre cerca de $30,5 \mathrm{~km}$ no território mineiro e $215,5 \mathrm{~km}$ na Bahia, onde é responsável pelo abastecimento de água dos principais municípios na área da bacia. Isso perfaz uma população abastecida superior a $250 \mathrm{mil}$ habitantes (IBGE, 2010). 


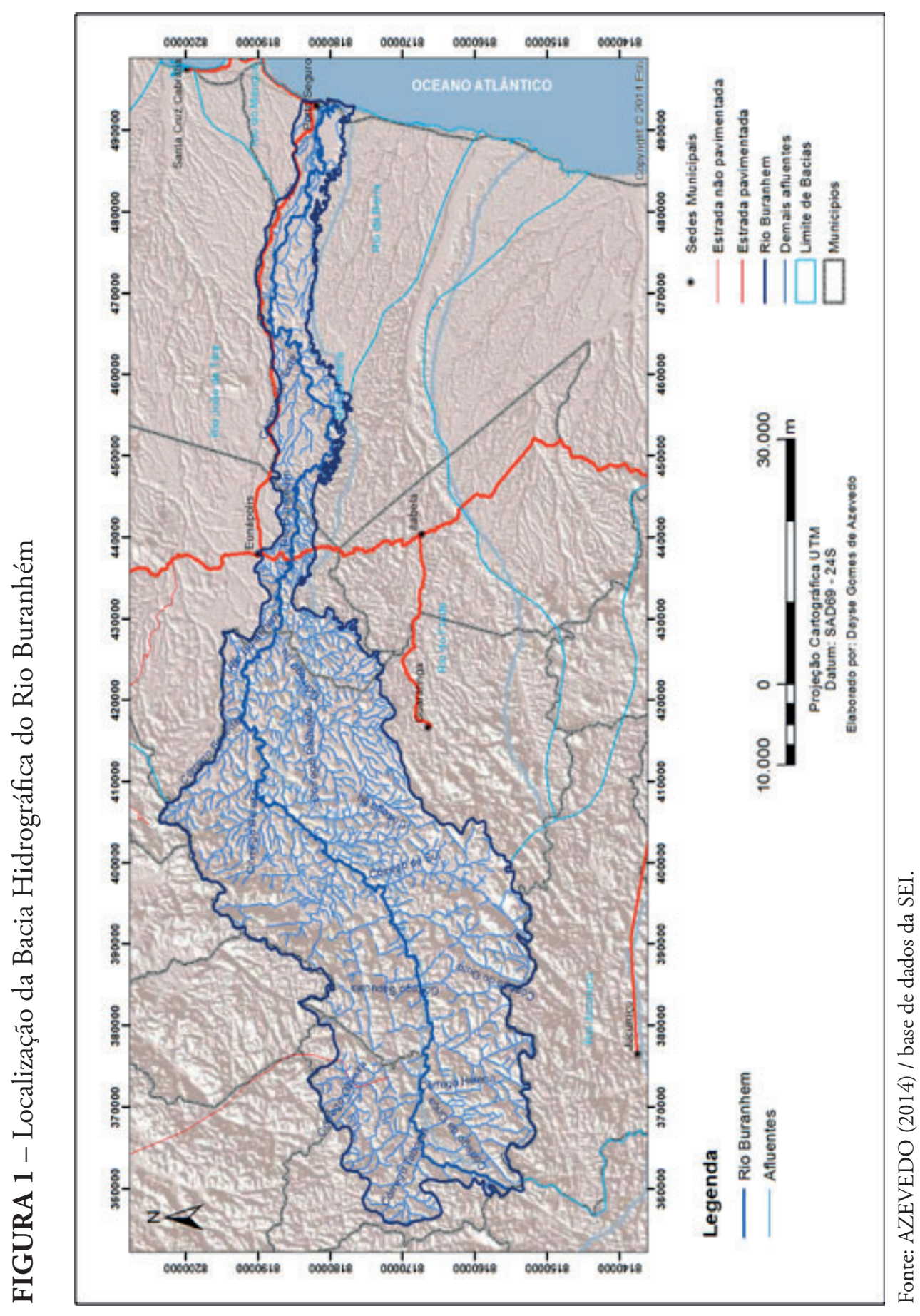

A bacia apresenta diversos tipos de substrato rochoso, cobertura do solo e relevo, contribuindo para uma variedade de formas de uso e ocupação do solo. Seus remanescentes florestais concentram-se principalmente 
na porção oeste, nos Planaltos Soerguidos formados pela unidade litológica do Granito de Santa Maria do Salto e Bloco Montanhoso de Santo Antônio do Jacinto. Essas áreas possuem relevo ondulado e boa drenagem. Já os fragmentos da porção leste estão dispersos ao longo do rio Buranhém. $\mathrm{O}$ cultivo do cacau no sistema cabruca também se dá nas proximidades deste rio, mais especificamente nos Tabuleiros Costeiros. Por fim, as poucas áreas de reflorestamento de eucalipto estão na porção norte; enquanto as áreas de pastagem distribuem-se por toda a extensão da bacia, configurando-se como a matriz da paisagem.

\section{Métodos e Técnicas de Pesquisa}

A metodologia foi dividida em etapas, conforme apresentado na Figura 2. Inicialmente, foram adquiridas as folhas topográficas Guaratinga, Salto da Divisa, Santo Antônio do Jacinto, Porto Seguro e Jacinto, elaboradas pela Superintendência de Estudos Econômicos e Sociais do Estado da Bahia (SEI) em escala 1:100.000. A partir dessas folhas e utilizando um Sistema de Informação Geográfica (SIG), foi organizada a base cartográfica da bacia com dados da malha rodoviária, limites municipais, rede de drenagem e localidades. Já os dados de relevo foram extraídos de arquivos TOPODATA (quadrícula 16S405ZN), cedidos pelo Instituto Nacional de Pesquisas Espaciais (INPE). A partir daí e utilizando novamente o SIG, foram elaborados seis planos de informaçáo, que caracterizam atributos físicos e ambientais da bacia. São eles: hidrografia, substrato rochoso, formas de relevo, hipsometria, declividade e tipos de solo. 
FIGURA 2 - Fluxograma do método adotado

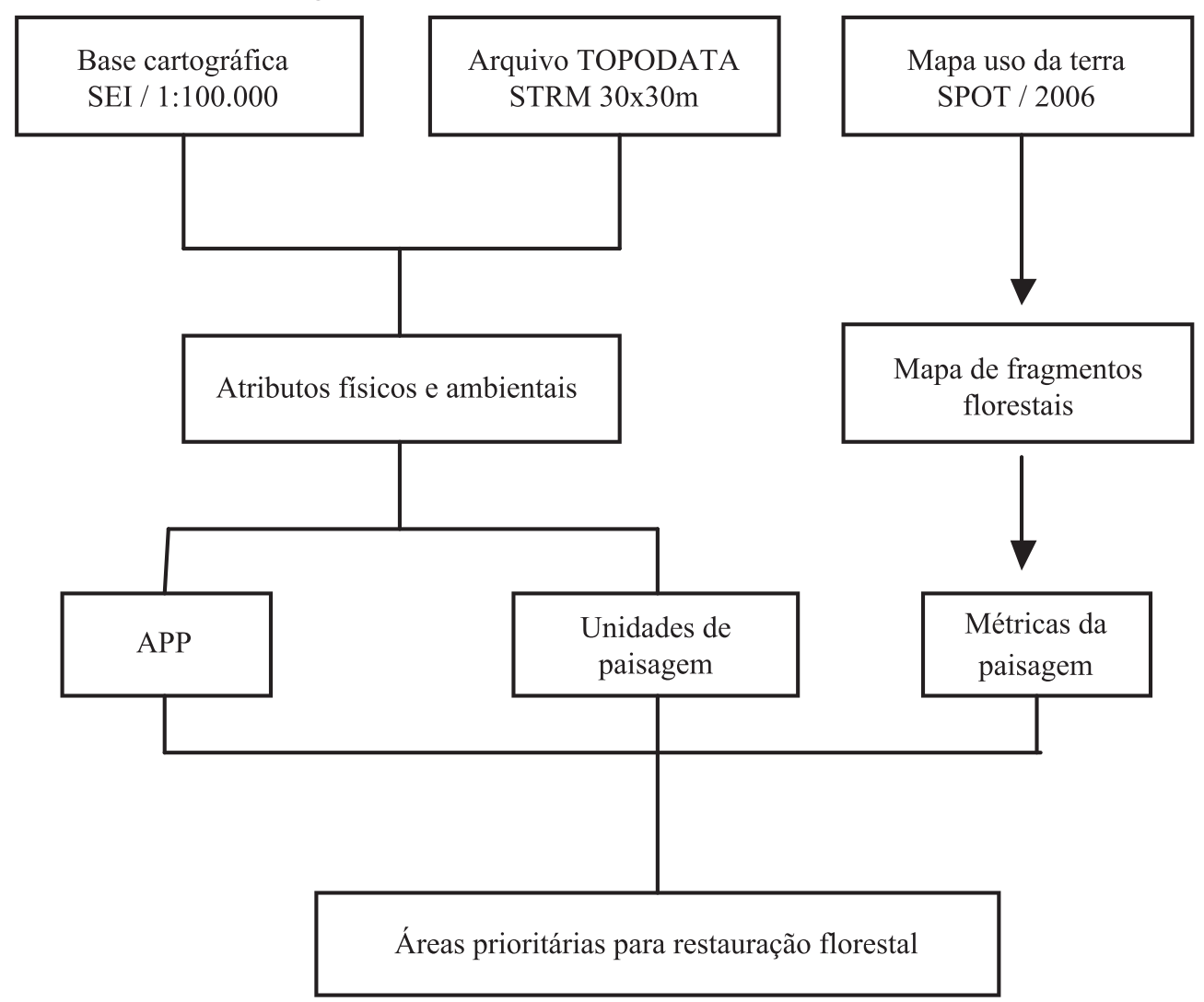

Fonte: elaborado pelos autores.

Paralelamente, um mapa dos fragmentos florestais da bacia foi elaborado a partir do mapeamento multitemporal de uso da terra do extremo sul da Bahia, realizado em 2007 pela GEOATLÂNTICA, em escala 1:25.000 (RIBEIRO et al., 2012). Para a análise desses fragmentos, foram calculadas, utilizando a extensão Patch Analyst 5.0 do ArcGIS 10.1, as seguintes métricas da paisagem: tamanho, densidade, forma, borda e proximidade. Os dados obtidos foram dispostos numa tabela.

De modo a efetivar a análise integrada da bacia, foram delimitadas dez unidades de paisagem (unidades geoambientais) com base nas formas de relevo, tipos de substrato rochoso, hipsometria e declividade do terreno. Em seguida, foram calculadas, para cada unidade, as métricas de tamanho, densidade e forma. Esses cálculos serviram para caracterizar a cobertura florestal nessas unidades. Ainda com o intuito de subsidiar a análise integrada, foram delimitadas, a partir de uma simulação no SIG, as Áreas de Preserva- 
ção Permanente (APP) da bacia, segundo o atual Código Florestal Brasileiro (BRASIL. Lei 12.651/2012). Com isso, pôde-se finalmente identificar as áreas prioritárias para a restauração florestal.

\section{Análise da fragmentaçáo florestal}

O mapeamento das áreas florestais contabilizou 1.923 fragmentos de tamanho acima de 3 ha (Figura 3), recobrindo $423,82 \mathrm{~km}^{2}$.

A análise desses fragmentos apresenta-se resumida na Tabela 1 . Observa-se que a classe 2 (5-10 ha) apresenta o maior número de fragmentos (558); seguida pela classe 1 (3-5 ha), com 533; e a classe 3 (10-25 ha), com 468 fragmentos. Por outro lado, a classe 7 (>250 ha) possui o menor número de fragmentos (17). Mas, se considerada a relação entre o número de fragmentos e a área de cobertura, esta classe representa a maior parcela $(8.321,52$ ha) da área total mapeada. Já o tamanho médio da mancha (MPS) geral é de 22,04 ha e o desvio padrão do tamanho da mancha (PSSD) geral é de 58,19 ha, indicando a existência de fragmentos com área muito acima e/ou muito abaixo do valor médio. Por exemplo, mais da metade dos fragmentos mapeados estão nas classes menores 1 e 2; já na classe 7, o MPS é de 489,59 ha e o PSSD é de 288,50 ha, valores estes considerados altos. 


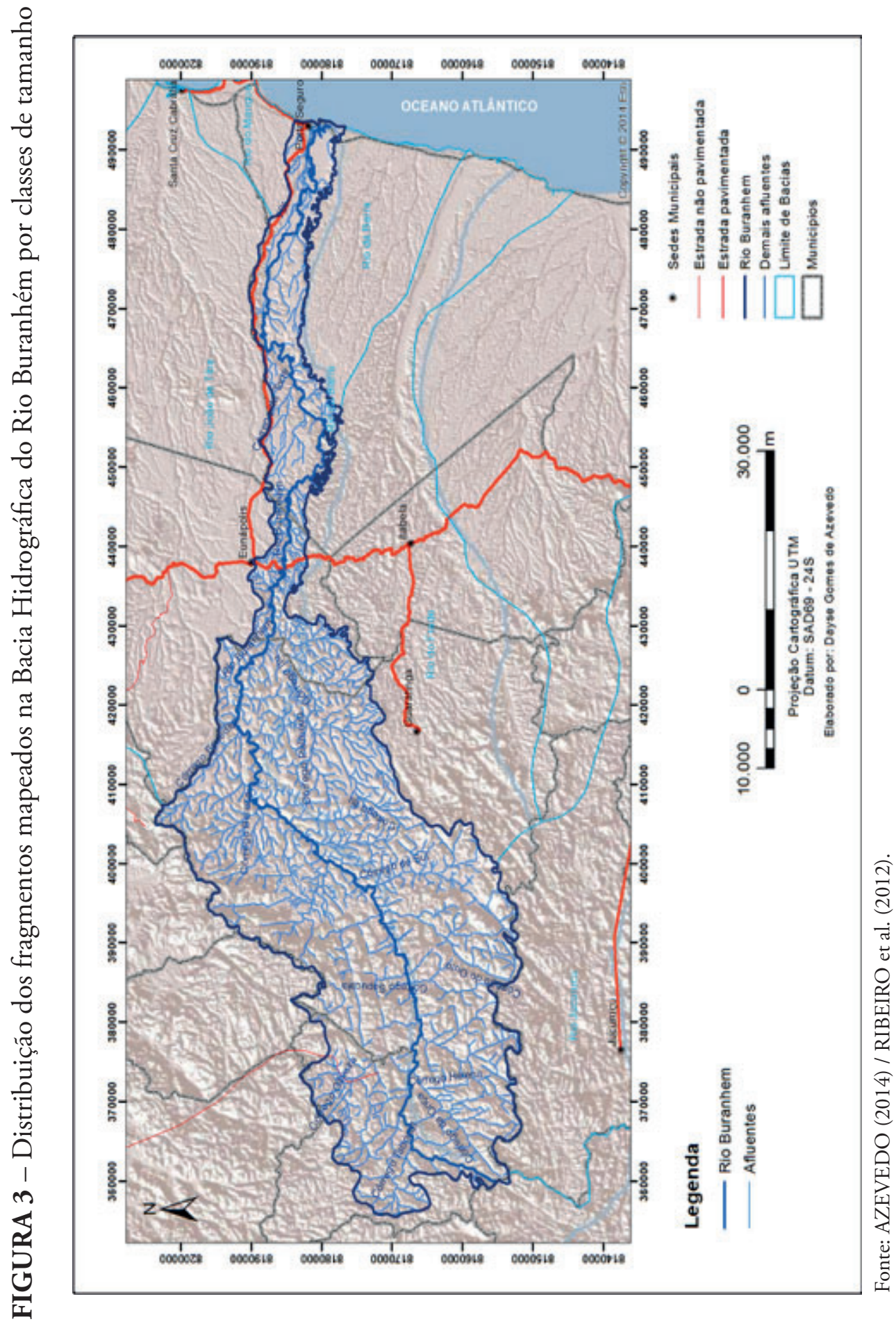


हี่

ص

운

움

苞

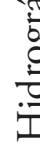

돈

I

$\frac{\text { o }}{\pi}$

ฮัฐ

竎

5

กี่

$\frac{\sqrt{3}}{\frac{\pi}{3}}$

¿

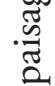

ซ

䓠

点

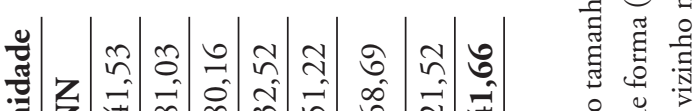

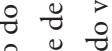

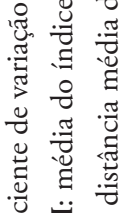

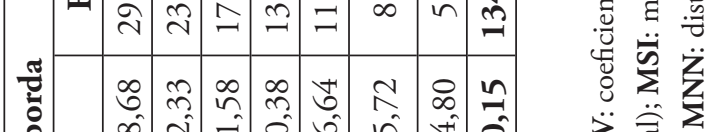

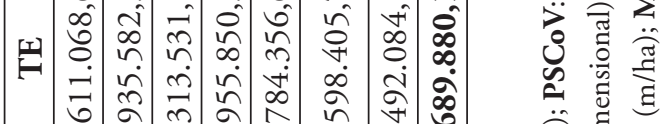

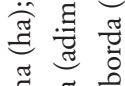

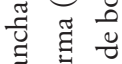

สี

ช $\frac{\pi}{0}$

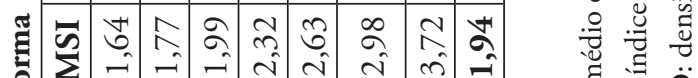

:

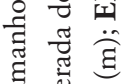

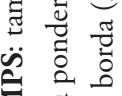

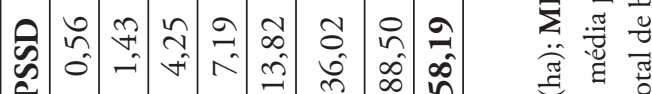

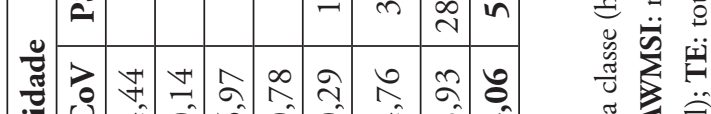

荡

อั

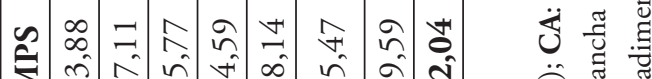

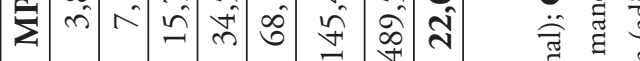

\&

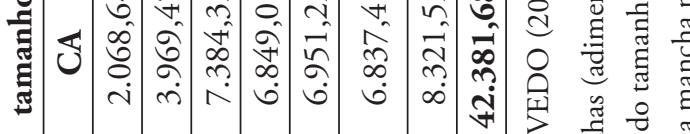

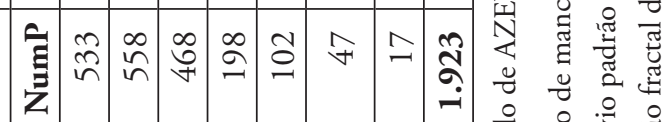

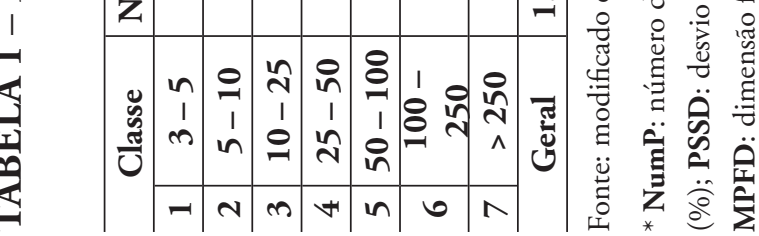


A análise da forma dos fragmentos foi feita com base no índice de forma, que compara o tamanho do fragmento ao de um círculo de mesma área. Quanto mais alto o seu valor, mais irregular e/ou alongada é a forma do fragmento; e quanto mais próximo de 1, mais circular é sua forma. Assim, analisando a dimensão fractal da mancha média (MPFD), os valores obtidos $(1,32$ e 1,33) apontam pequenas variaçóes na rugosidade das formas.

Além disso, a análise das métricas de borda mostra um total de borda (TE) de $1.313 .531,58 \mathrm{~m}$ para a classe 3 e de $492.084,80 \mathrm{~m}$ para a classe 7. Ou seja, os fragmentos da classe 3 (menores) apresentaram maior razáo borda/área (ED) quando comparados aos fragmentos da classe 7 (maiores). Esses resultados indicam um menor efeito de borda para os grandes fragmentos e vice-versa.

Finalmente, as métricas de proximidade, expressas pela distância média do vizinho mais próximo (MNN), revelam que os fragmentos pequenos (classes 1 e 2) estáo menos isolados que os demais fragmentos florestais da bacia. Segundo Metzger (1999), o isolamento de fragmentos é uma séria consequência da quebra na continuidade da paisagem e da intensificação do processo de fragmentação, pois, ao restringir o deslocamento de espécies entre manchas, tais isolamentos podem causar diminuição na variabilidade genética e mesmo extinção de espécies nativas. Na bacia do rio Buranhém, constatou-se que a preservação de fragmentos pequenos e próximos (classes 1 e 2) é de extrema importância para a percolaçáo da paisagem, pois eles podem funcionar como trampolins ecológicos.

\section{Delimitaçáo das áreas de preservaçáo permanente}

O mapa com a distribuição das Áreas de Preservação Permanente (APP) na Bacia Hidrográfica do Rio Buranhém (Figura 4) foi elaborado utilizando-se o SIG. Foram mapeadas as áreas referentes às nascentes, faixas marginais a corpos d'água, manguezais e áreas úmidas, áreas com declividade superior a $45^{\circ}$, e topos de morro e montanha.

As áreas protegidas pelo Código Florestal (APP) equivalem a 13,15\% do total da bacia, sendo as APP de faixa marginal a corpos d'água as mais representativas, com pouco mais da metade da área total de APP na bacia. 


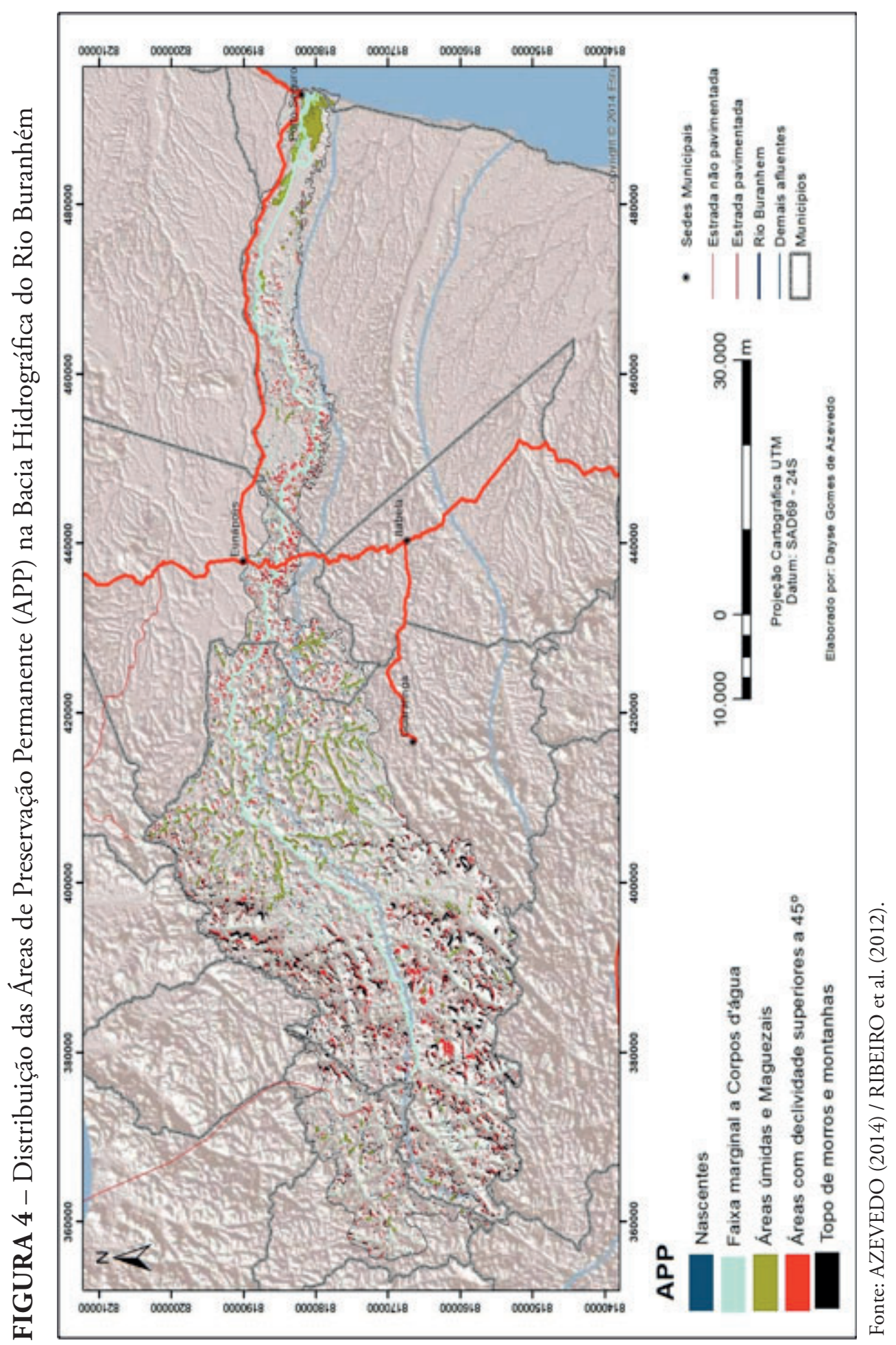




\section{Análise integrada da paisagem}

Para a análise integrada da paisagem da bacia do rio Buranhém, foram delimitadas dez unidades de paisagem com seus respectivos fragmentos florestais, conforme apresentado na Figura 5.

Constatou-se que em quase todas as unidades a matriz da paisagem é formada por áreas de pastagem e que em todas as unidades encontramse Áreas de Preservaçáo Permanente de faixa marginal a corpos d'água. A seguir, apresenta-se uma síntese da análise integrada por unidade.

A unidade $1\left(48,64 \mathrm{~km}^{2}\right)$ é formada por acumulação fluvial e ali predominam gleissolos. Essa acumulação ocorre nos vales fluviais, situados abaixo do nível dos terraços marinhos. Quanto ao uso do solo, destacam-se as áreas de cabruca ao longo do rio Buranhém. Os 31 fragmentos florestais, geralmente pequenos, ocupam uma área de 271,40 ha e apresentam forma mais arredondada (MSI de 1,86) que a média dos demais fragmentos mapeados (MSI geral de 1,94). As APP correspondem a áreas úmidas e manguezais que se encontram degradados e a faixas marginais a corpos d'água que se encontram parcialmente florestadas, visto que parte destas está ocupada por pastagens e cabruca.

A unidade 2 é a menor das unidades delimitadas neste estudo, com uma área de $23,65 \mathrm{~km}^{2}$. Ela é formada por acumulação flúvio-marinha nas baixadas litorâneas, onde predominam gleissolos e espodossolos. Essa acumulação ocorre próxima à desembocadura dos rios e está associada aos depósitos de pântanos e mangues atuais. Aqui, a matriz da paisagem é formada por campos úmidos em estágio avançado de degradação. Os oito fragmentos, que se dividem em três classes, têm forma alongada (MSI de 2,26) e ocupam a menor área de cobertura florestal (78 ha) dentre as unidades aqui delimitadas. As APP correspondem a manguezais e áreas úmidas que se encontram degradados e faixas marginais a corpos d'água.

A unidade $3\left(189,68 \mathrm{~km}^{2}\right)$ é formada pelos Tabuleiros Costeiros, sustentados pelos sedimentos do Grupo Barreiras. Nesta unidade predominam latossolos. Quanto ao uso do solo, destacam-se as áreas de pastagem em topos planos, permeadas por reflorestamentos de eucalipto, e áreas de cabruca. Os 191 fragmentos possuem maior média de tamanho (MPS de 27,59), ocupando uma área de 5.269,51 ha. Eles apresentam forma irregular (MSI de 2,04). As APP encontram-se parcialmente florestadas, sendo que muitas foram ocupadas por pastagens. 


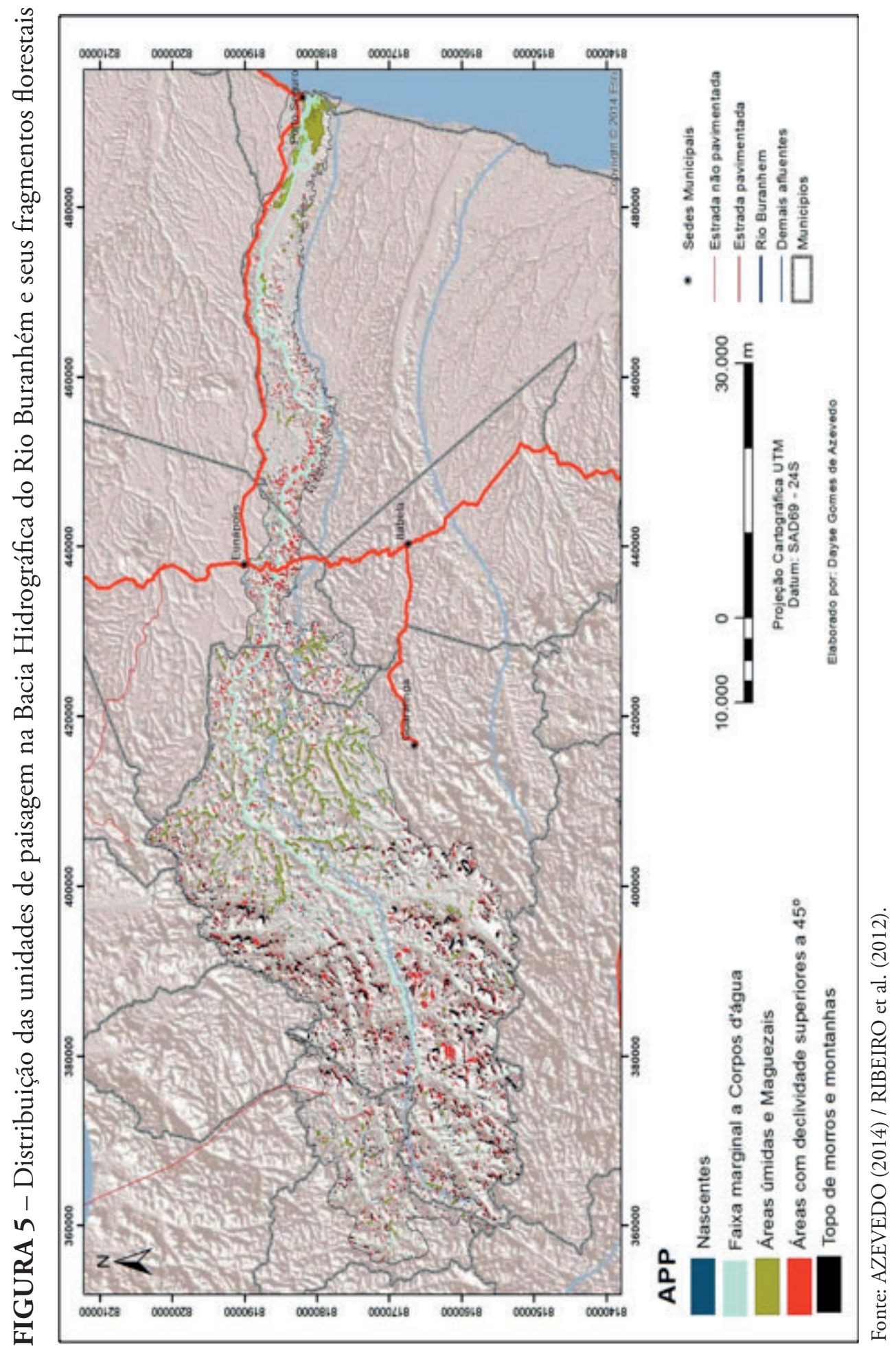


A unidade $4\left(168,84 \mathrm{~km}^{2}\right)$ caracteriza-se por relevo suavemente ondulado. É formada por terrenos pré-litorâneos do Complexo Itapetinga, onde predominam latossolos e argissolos. Os 191 fragmentos ocupam uma área de 5.292,28 ha e estão localizados principalmente nos vales encaixados. Quanto à forma, os fragmentos são irregulares (MSI de 1,97). As APP dessa unidade e da seguinte (5) também se encontram parcialmente florestadas, sendo que muitas foram ocupadas por pastagens, inclusive aquelas de áreas com declividade superior a 45 graus.

A unidade $5\left(490,72 \mathrm{~km}^{2}\right)$ é formada por terrenos pré-litorâneos do Complexo Jequitinhonha, onde predominam latossolos. Os 454 fragmentos ocupam uma área de $8.481,58$ ha e apresentam forma mais arredondada (MSI de 1,85) que a média da bacia.

A unidade $6\left(99,33 \mathrm{~km}^{2}\right)$ é formada por terrenos pré-litorâneos do Granito Santa Maria do Salto. Tanto nesta unidade como nas quatro seguintes, há predomínio de latossolos e argissolos. Quanto ao uso do solo, destacam-se as áreas de pastagem em fundos de vale e encostas. Os 76 fragmentos ocupam uma área de $1.526,96$ ha e apresentam forma mais alongada (MSI de 1,95). Como a unidade 10, esta unidade apresenta poucas áreas protegidas por lei, com poucos fragmentos florestais.

A unidade $7\left(184,23 \mathrm{~km}^{2}\right)$ é formada por terrenos pré-litorâneos dos Complexos Itapetinga e Jequitinhonha. Os 194 fragmentos ocupam uma área de 3.189,80 ha e também são mais arredondados (MSI de 1,77) que a média. Isso se deve provavelmente à presença de colinas, que impedem a secção dos fragmentos pela rede de drenagem. As APP, principalmente de nascente, encontram-se desmatadas.

A unidade $8\left(77,58 \mathrm{~km}^{2}\right)$ caracteriza-se por relevo ondulado sustentado por substrato granítico. Ela está localizada nos Planaltos Soerguidos, formados pelo Bloco Montanhoso dos Granitos de Guaratinga - São Paulinho. Esta unidade apresenta o maior número de fragmentos (1.201), mas ocupa uma área de apenas 92 ha. Isso se deve ao fato destes apresentarem tamanho médio de 13 ha, estando, portanto, entre os menores da bacia. Esses fragmentos também apresentam forma mais arredondada (MSI de $1,85)$ que a média. Quanto às APP, observa-se que, inclusive as de nascente, estão ocupadas por pastagens; fato extremamente prejudicial para a manutenção das características dos seus ecossistemas e da qualidade da água.

A unidade 9 é a maior das unidades delimitadas neste estudo, com uma área de $1.187,01 \mathrm{~km}^{2}$. Como as unidades 8 e 10, ela também se localiza 
nos Planaltos Soerguidos, associados ao Bloco Montanhoso dos Granitos de Santo Antônio do Jacinto e Santa Maria do Salto. Ainda que, como as demais, esta unidade esteja em grande parte coberta por pastagens, ela apresenta a maior área de fragmentos florestais, com 16.791,10 ha dispersos pela unidade. Na porção norte, verifica-se maior concentração de fragmentos, devido à maior altitude; o que dificulta a fragmentação antrópica. Porém, os fragmentos são na maior parte alongados (MSI de 1,95), estando suscetíveis ao efeito de borda. Esta unidade apresenta também a maior área em APP, tendo o maior número de APP de faixa marginal a corpos d'água, de nascente e de topos de morro e montanha. Ali, os remanescentes florestais encontram-se limitados pelos vales adjacentes.

A última unidade delimitada neste estudo é a unidade 10, com área de $35,08 \mathrm{~km}^{2}$. Ela está localizada na parte adjacente da cadeia de montanhas dos Planaltos Soerguidos do Complexo Jequitinhonha. Os 28 fragmentos ocupam uma área de 279,39 ha e apresentam forma irregular (MSI de 2,04), estando muitas vezes isolados e junto a topos de morro. Esta é a unidade com menor área protegida por lei, com situaçáo bastante crítica devido às áreas de pastagem.

\section{Identificação de áreas prioritárias para a restauraçáo florestal}

A definição das áreas prioritárias para a restauração florestal na bacia baseou-se num conjunto de critérios referentes aos seus atributos físicos e ambientais, estágio do processo de fragmentação e estado de intervenção antrópica nas APP. A Figura 6 ilustra as áreas prioritárias para a restauração florestal, identificadas no presente estudo, divididas entre as dez unidades de paisagem e com seus respectivos fragmentos. 


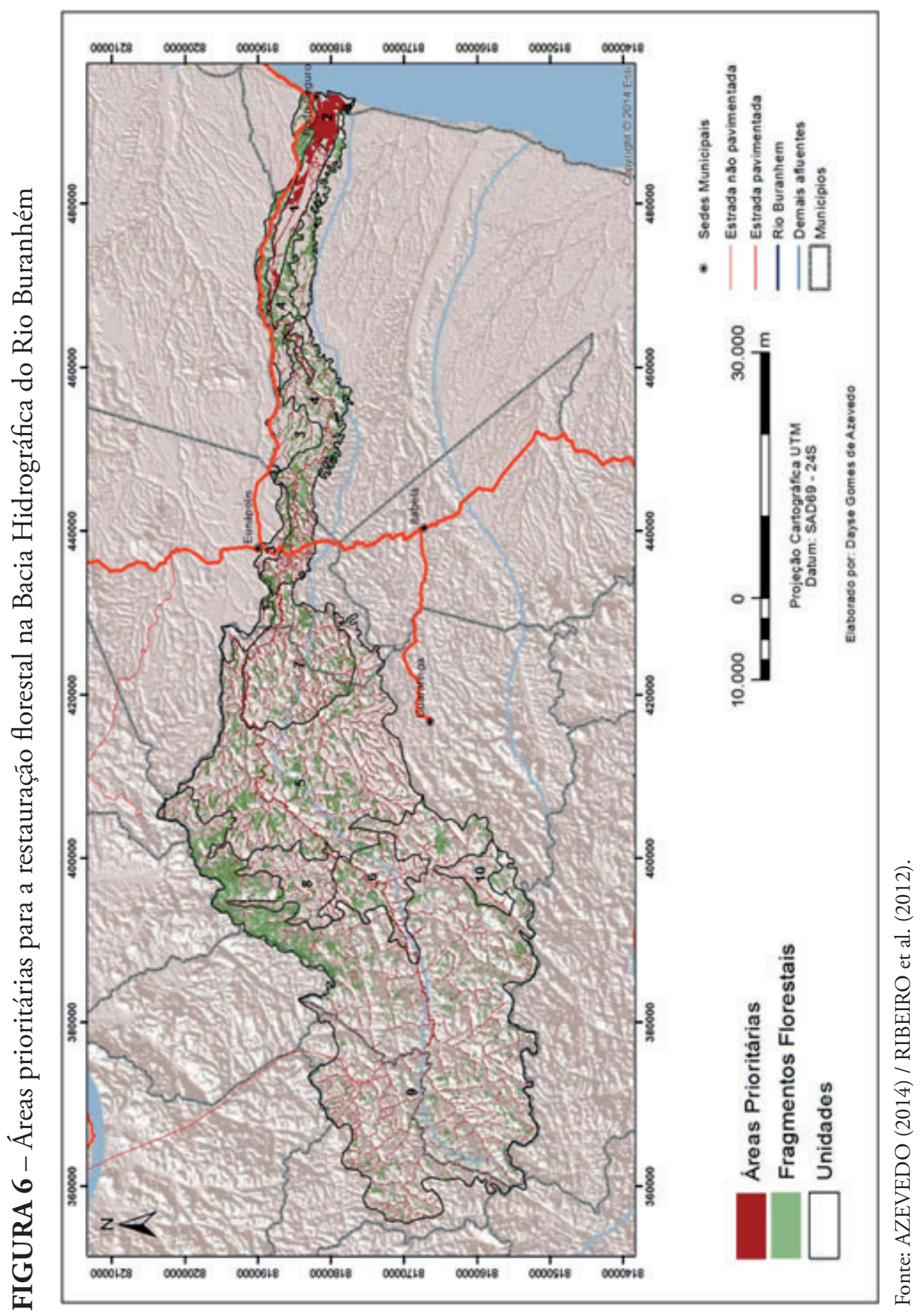


Observa-se que as unidades litorâneas (unidades 1 e 2) apresentam como prioridade a restauração de manguezais e áreas úmidas. Na unidade 3, que corresponde aos Tabuleiros Costeiros do Grupo Barreiras, identificou-se como áreas prioritárias tanto as APP em torno de nascentes e rios como em encostas. Nas unidades com relevo plano a colinoso (unidades 4 a 7), destacam-se como prioritárias as encostas desmatadas. E as áreas prioritárias nas unidades associadas a relevos montanhosos (unidades $8 \mathrm{a}$ 10) situam-se em torno de nascentes e margens de cursos d'água.

\section{Comentários Finais}

A bacia do rio Buranhém, como tantas outras bacias hidrográficas no Brasil, enfrenta problemas ambientais decorrentes de um processo desordenado de ocupação do solo. Nesta bacia, destaca-se a substituição da vegetaçáo nativa por áreas de pastagem, inclusive nas APP.

Atualmente, a bacia está ocupada por $71,22 \%$ de áreas de pastagem e apenas $18,44 \%$ de fragmentos florestais em diferentes estágios de regeneração. Destes, $56 \%$ têm entre 3 e 10 ha (classes de tamanho 1 e 2) e os poucos fragmentos com mais de 250 ha (classe 7) encontram-se isolados, prejudicando a percolação da paisagem. Além disso, a aplicação das métricas de forma demonstrou que os fragmentos com mais de 100 ha (classes 6 e 7) são muito alongados ou irregulares, o que aumenta sua suscetibilidade ao efeito de borda.

Nas APP, que representam 13,13\% da bacia, a ocupação desordenada no entorno de nascentes, rios, campos úmidos, manguezais, restingas e encostas intensifica o processo de fragmentação da paisagem, levando ao desequilíbrio de seus ecossistemas.

Nas áreas prioritárias identificadas neste estudo, destaca-se a necessidade de restauração da mata ciliar no entorno de rios e nascentes no interior da bacia, bem como dos manguezais e campos úmidos no litoral. Deste modo, espera-se viabilizar a conectividade funcional da paisagem e a manutençáo do fluxo de espécies entre os fragmentos. 


\section{Referências}

AZEVEDO, D. G. de. Estudo da fragmentaçáo da paisagem na definição de áreas prioritárias para recuperaçáo ambiental na bacia do rio Buranhém. 2014. 86 f. Dissertação (Mestrado em Desenvolvimento Regional em Meio Ambiente ) - Universidade Estadual de Santa Cruz, Ilhéus, BA, 2014.

BRASIL. Lei 12.651, de 25 de maio de 2012. Dispõe sobre o Novo Código Florestal Brasileiro. Disponível em: <http://www.planalto.gov.br/ccivil_03/ato2011-2014/2012/lei/112651.htm>. Acesso em: 23 jun. 2015.

FORMAN, R. T. T.; GODRON, M. Landscape ecology. New York: John Wiley \& Sons, 1986.

INSTITUTO BRASILEIRO DE GEOGRAFIA E ESTATÍSTICA IBGE. Censo demográfico 2010. Disponível em: <http://censos2010. ibge.gov.br/>. Acesso em: 24 jul. 2015.

LANNA, A. E. L. Gestão dos recursos hídricos. In: TUCCI, C. E. M. (Org.) Hidrologia: ciência e aplicação. 2. ed. Porto Alegre: ABRH, 1997.

METZGER, J. P. Estrutura da paisagem e fragmentação: análise bibliográfica. Anais da Academia Brasileira de Ciências, v. 71, n. 3-I, p. 445463, 1999.

METZGER, J. P. O que é ecologia de paisagens? Biota Neotropica, Campinas, SP, v. 1, n. 1 e 2, p. 1-9, 2001.

NUCCI, J. C. Origem e desenvolvimento da ecologia e da ecologia da paisagem. Estudos Geográficos - Revista Eletrônica de Geografia, Rio Claro, SP, v. 2, n. 1, p. 77-99, 2007.

RIBEIRO, M. C. et al. Monitoramento independente da cobertura florestal das bacias setentrionais do extremo sul da Bahia. Relatório técnico. Porto Seguro, BA: Responsável pela publicação, 2012. 


\title{
CAPÍTULO 6
}

\section{Aspectos geoambientais dos recursos hídricos das propriedades rurais do Projeto Barro Preto, Bahia}

\author{
Emerson Ranniely Mendes dos Santos \\ Quintino Reis de Araujo \\ Antônio Fontes de Faria Filho \\ Rodrigo Batista Vieira \\ José Francisco Assunção Neto \\ Leonardo Celso Costa Cabral \\ Ednaldo Ribeiro Bispo
}

\section{Introdução}

As alterações na quantidade, distribuição e qualidade dos recursos hídricos interferem na sobrevivência humana e das demais espécies, fazendo com que o desenvolvimento econômico e social dos países dependa da disponibilidade de água de boa qualidade e da capacidade de sua conservação e proteção (TUNDISI, 1999). A água tem um papel fundamental para a manutençáo da vida no planeta e os rios sáo os vetores que distribuem este bem, de modo que a sua conservação é extremamente necessária. Uma das formas de se conservar um rio é por meio de suas nascentes, já que tais ambientes garantem um fluxo contínuo de água.

Conforme a Agência Nacional de Águas (ANA), o Programa Produtor de Água tem como objetivos: a melhoria da qualidade da água através do incentivo à adoçáo de práticas que promovam o abatimento da sedimentação; o aumento da oferta de água (e sua garantia) e a conscientização dos produtores e consumidores de água da importância da gestáo integrada de bacias hidrográficas. Esse programa adota como estratégias a "compra" dos benefícios (produtos) gerados pelo participante (conceito "provedor-recebedor"); pagamentos proporcionais ao abatimento de erosão proporcionado e ampliaçáo da área florestada; flexibilidade no que diz respeito 
a práticas e manejos propostos; assistência técnica e extensão rural; edital para seleçáo dos projetos (ANA, 2012). Para tanto, os produtores devem atender requisitos como: adotar práticas conservacionistas efetivas, comprovar a conservação de áreas produtoras de água e realizar, se necessário, a recuperação de florestas.

Os recursos seriam obtidos por meio da cobrança pelo uso da água, de convênios de entidades públicas e outras instituiçôes e do plano plurianual de cada município.

Em várias partes do país, iniciativas ainda que incipientes, remuneram produtores rurais que conservam mananciais. Proprietários de terras que possuem nascentes dentro de suas propriedades assinam um contrato com a prefeitura do município em que se encontram e recebem uma bonificação para conservá-las e adotar práticas que respeitem o meio ambiente. Quando assinam esse contrato, eles comprometem-se a cumprir a lei de preservação/ conservação ambiental.

O pagamento por serviços ambientais é uma política ambiental que tem como objetivo transferir recursos, monetários ou náo monetários, para aqueles que ajudam a conservar e preservar recursos naturais. A identificação das nascentes é um instrumento fundamental para a definiçãa de áreas prioritárias à conservaçáo.

A utilização de geotecnologias permite referenciar informaçóes no espaço, navegar por áreas urbanas e rurais, identificando cidades, florestas, rios, praias, curvas de níveis, ocupação territorial, além de dados estatísticos e operacionais relacionados aos lugares acessados, configurando-se, portanto, como grande aliada no planejamento ambiental. Além disso, podem estimar resultados, simular modelos realísticos de processos físicos, ambientais ou mercadológicos, monitorar efeitos de intervençóes e construir cenários futuros, buscando sempre as alternativas mais adequadas para cada caso (CÂMARA; MEDEIROS, 1996).

Ferramentas de geoprocessamento têm sido importantes em trabalhos de análises geoambientais. Costa, Souza e Brites (1996) identificaram categorias de Áreas de Preservação Permanente (APP) e elaboraram um diagnóstico qualitativo e quantitativo de uso da terra em uma área no município de Viçosa, Minas Gerais. No mesmo município, Soares et al. (2002) fizeram um estudo para analisar a situaçáo de áreas de uso inadequado em uma microbacia, utilizando um restituidor fotográfico para indicar a localização das Áreas de Preservação Permanente. Oliveira (2002), 
utilizando ferramentas do geoprocessamento, identificou de modo automático as APP situadas em topos de morros e em linhas de cumeada.

O Projeto Agroflorestal Barro Preto propóe a conservação produtiva para o sistema agroflorestal cacau-cabruca com o propósito de garantir o uso, a conservaçáo e a produção em um mesmo espaço, sem provocar alteraçóes substanciais na estrutura e funcionamento da paisagem. Esse projeto é resultante de uma parceria do Centro Mars de Ciência do Cacau com a Prefeitura Municipal de Barro Preto, o Sindicato dos Produtores Rurais e a Comissáo Executiva do Plano da Lavoura Cacaueira (CEPLAC) com o objetivo de estabelecer as bases de uma proposta inovadora de desenvolvimento sustentável para a regiáo cacaueira da Bahia.

O Projeto está centrado no município de Barro Preto e envolve a área do divisor de águas das bacias dos rios Cachoeira e Almada. Nesta região, o cultivo de cacau (Theobroma cacao L.), predominantemente, utiliza o sistema agroflorestal cacau-cabruca, que é de grande importância ecológica, pois conserva as árvores nativas e as usa no sombreamento de cacaueiros.

Diante desse contexto, este capítulo apresenta os resultados de um estudo sobre os imóveis rurais que fazem parte do Projeto Barro Preto e que têm potencial para se tornarem "Imóveis Produtores de Água".

\section{Caracterização da área de estudo}

O município de Barro Preto faz parte da regiáo cacaueira tradicional e está localizado na Mesorregiáo do Sul Baiano. Possui uma área estimada de $128,38 \mathrm{~km}^{2}$ e uma populaçáo de 6.453 habitantes. Sua sede está situada a $14^{\circ} 48^{\prime} 36^{\prime \prime} \mathrm{S}$ e 39॰ 28' 15" WG, limitando ao norte e ao leste com o município de Itajuípe, e ao sul e ao oeste com Itabuna (SEI, 2006) (Figura 1). 


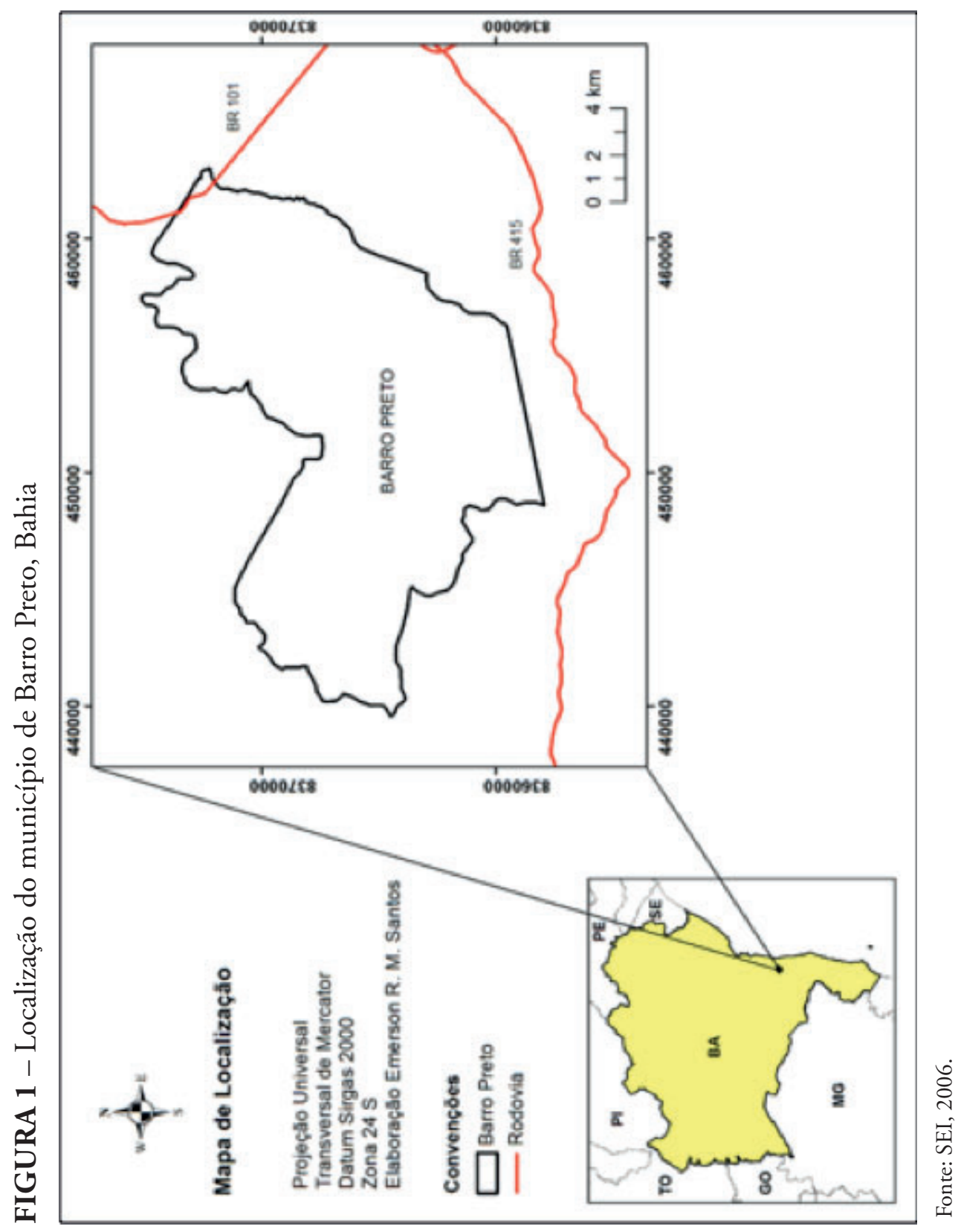

O Projeto Barro Preto visa a recuperação agronômica de plantações de cacau aliada à conservação ambiental, e este estudo envolve 11 imóveis rurais com potencial de se tornarem produtores de água (Tabela 1 e Figura 2) contemplados pelo Projeto. 
TABELA 1 - Imóveis rurais contemplados pelo Projeto Barro Preto com indicação de área total e área de cultivo de cacau

\begin{tabular}{|l|c|c|}
\hline Imóveis & Área Total (ha) & Área de Cacau (ha) \\
\hline Roçado Grande & 79,5 & 59,1 \\
\hline São Joaquim & 98,6 & 81,7 \\
\hline Sáo José & 271,8 & 240,2 \\
\hline Tuyuna Juruy & 124,0 & 68,4 \\
\hline Santa Rosa & 15,9 & 15,9 \\
\hline Fortaleza & 154,6 & 11,5 \\
\hline Cordialidade & 18,4 & 8,3 \\
\hline Bom Jesus & 114,0 & 70,0 \\
\hline Bela Cruz & 11,0 & 9,0 \\
\hline Bela Flor & 57,0 & 50,0 \\
\hline Nova Harmonia & 57,0 & 35,0 \\
\hline
\end{tabular}

Fonte: Dados da pesquisa.

\section{Métodos e Técnicas de Pesquisa}

Inicialmente, foram levantados junto ao Centro de Pesquisa do Cacau (CEPEC) da CEPLAC dados sobre hidrografia, tipos de solo e uso e ocupaçáo do solo do município de Barro Preto, entre outros, com o intuito de elaborar um banco de dados no Sistema de Informação Geográfica (SIG) ArcGIS 9.3. Por meio das plantas dos imóveis, foi realizada a vetorização e o georreferenciamento das propriedades. Para a identificação das nascentes, foram utilizadas fotografias aéreas (1964/65) do acervo de aerofotogrametria da CEPLAC, imagens do satélite LANDSAT 5, de 2015, disponibilizadas pelo Instituto Nacional de Pesquisas Espaciais (INPE), e imagens de alta resolução espacial, disponibilizadas no site do Google Earth. Para a conferência dos dados, foram realizadas saídas de campo nas áreas do Projeto.

Para uma melhor visualização da rede de drenagem e das formas de relevo, foi elaborado no SIG ArcGIS 9.3 o Modelo Digital de Elevação Hidrologicamente Consistente (MDEHC) a partir de imagens SRTM (CGIAR-CSI, 2014) fornecidas pelo Grupo Americano em Pesquisa e Agricultura Internacional.

Para a delimitação das APP, foram utilizados os critérios estabelecidos pelo atual Código Florestal (BRASIL. Lei 12.651/2012), que estabelece a preservação da vegetação em faixas de $30 \mathrm{~m}$ em cursos d'água cujo leito é inferior a $10 \mathrm{~m}$ de largura; corpos d'água, como lagos e lagoas, com até 20 
ha de superfície cuja faixa a ser preservada consiste em um raio de $50 \mathrm{~m}$; e áreas de nascentes e olhos d'água perenes, qualquer que seja sua situação topográfica, cujo raio mínimo de preservação deve ser de $50 \mathrm{~m}$. Para tanto, foi utilizado o comando buffer, situado nas ferramentas Analysis Tools do SIG ArcGIS 9.3.

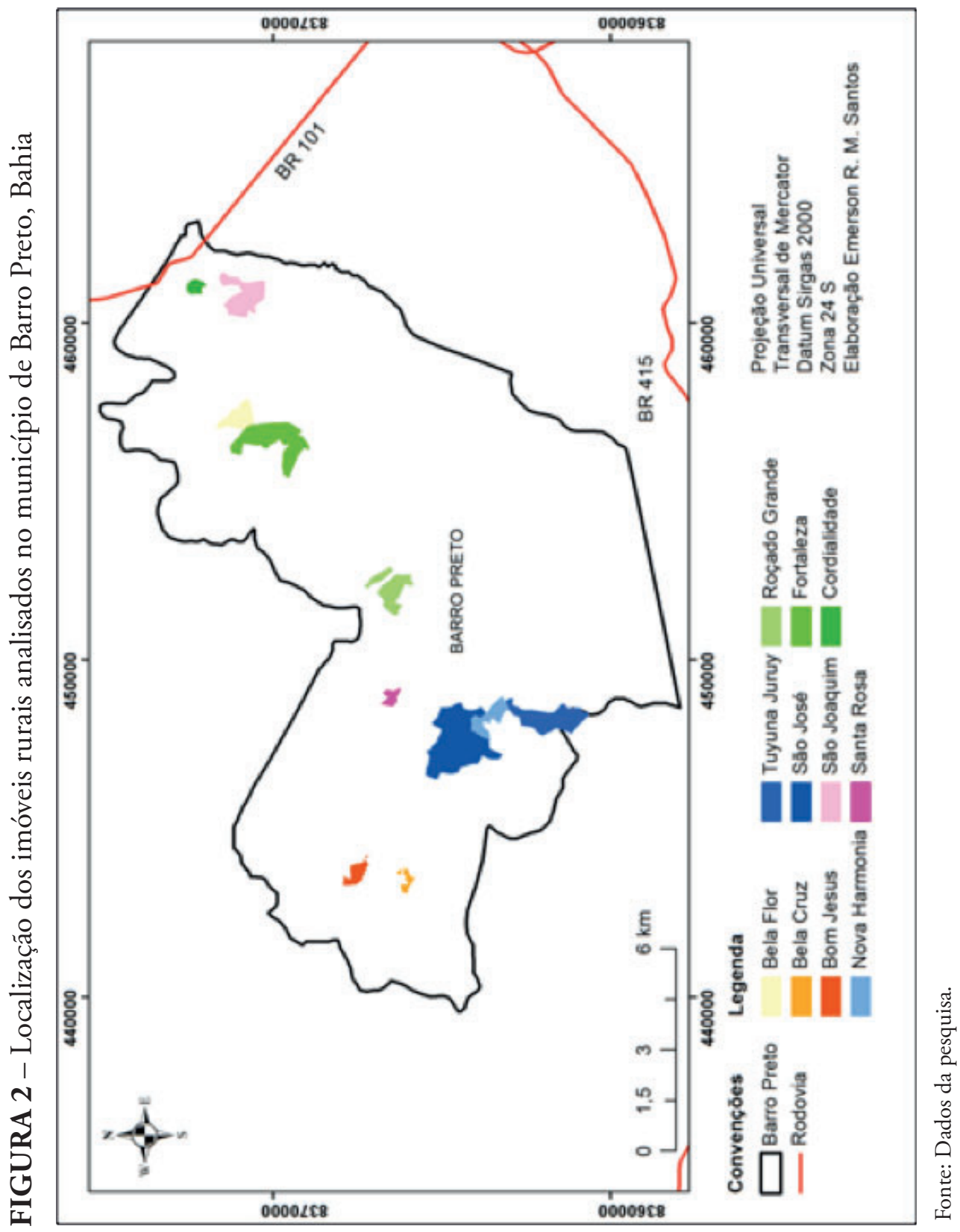




\section{Atributos geoambientais de Barro Preto}

No município de Barro Preto são encontradas características do bioma Mata Atlântica. O clima tropical úmido garante um grande volume pluviométrico, que sustenta a vegetação nativa.

A área de estudo possui relevo movimentado de rochas cristalinas, ígneas e metamórficas inseridas no planalto pré-litorâneo, com a presença de nascentes. Tais características geológicas proporcionam a intemperizaçáo dos solos, inclusive causando-lhes, em alguns casos, uma baixa fertilidade e tornando-os bastante suscetíveis à erosão pela força cinética da água em relevo com feiçóes íngremes. Entretanto, em função da adoção do sistema agroflorestal cacau-cabruca, foram mantidas as árvores de maior porte, o que garantiu a proteção do solo e o armazenamento de água no solo (PIMENTEL et al., 1992; REITSMA; PARRISH; McLARNEY, 2001; SPERBER et al., 2004). Porém, mais recentemente, a substituição do sistema cacau-cabruca por pastagens tem comprometido tais características.

$\mathrm{Na}$ maior parte das áreas agricultáveis, em especial naquelas mais suscetíveis à erosão, esta conversão de cultivos cacaueiros para pastoris pode representar maiores perdas de solo e água (BARRETO et al., 2008; INÁCIO et al., 2005; PAIVA; ARAUJO, 2012).

A rede de drenagem do município de Barro Preto é apresentada na Figura 3. A hidrografia dos imóveis rurais foi registrada a partir da hierarquização de rios de segunda e terceira ordem, além dos rios de primeira ordem vinculados às áreas de nascentes. 


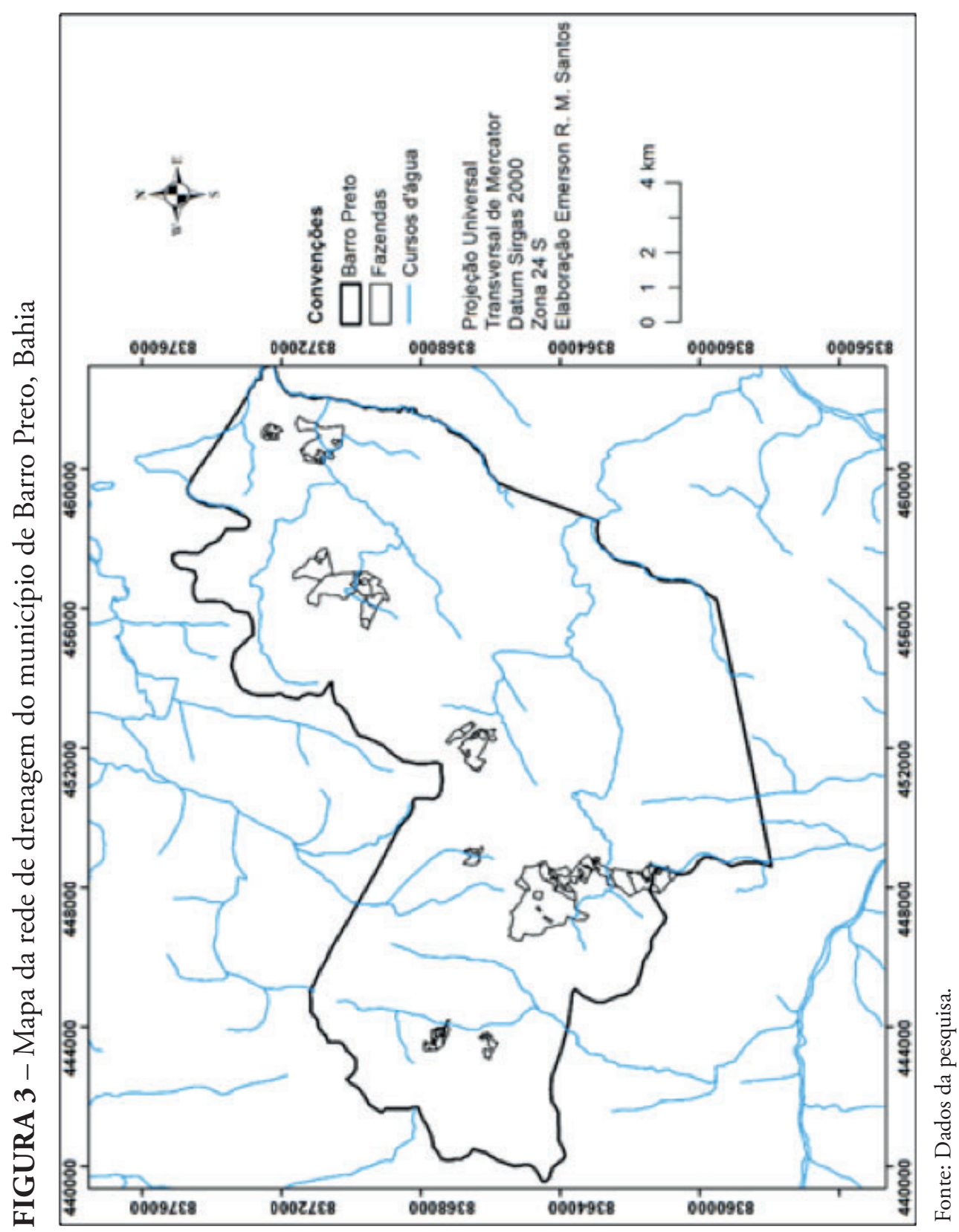

A análise da Figura 4 mostra que, no município, há um predomínio de solos com horizonte $\mathrm{B}$ textural, com destaque, em função da maior área de ocorrência, para as classes de Nitossolo Háplico e Argissolo Vermelho-Amarelo, solos ricos em nutrientes, de grande potencialidade de produção agrícola e de funçôes ambientais. Por outro lado, por apresentarem um gradiente textural entre os horizontes A e B, estes solos podem apresentar uma 
diminuição da velocidade de infiltração da água no perfil e, principalmente em áreas de maiores declividades, revelam séria suscetibilidade à erosão e alagamentos. Assim, a morfologia do solo pode gerar uma combinaçáo prejudicial, agravada pelo fato de chover $2.500 \mathrm{~mm}$ por ano no município, uma taxa muito elevada quando comparada com outras regióes da Bahia.

FIGURA 4 - Mapa de solos do município de Barro Preto, Bahia

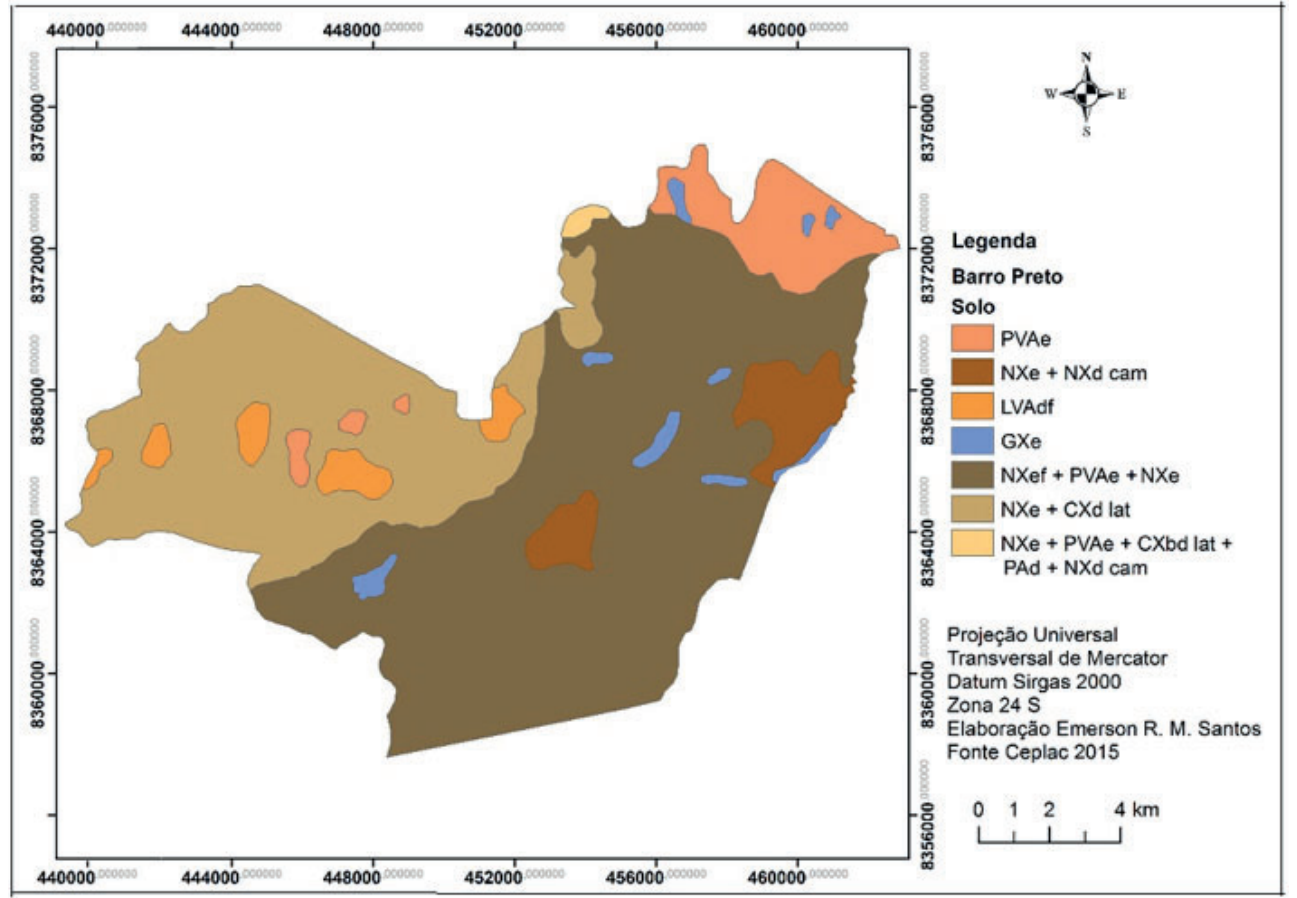

Fonte: Dados da pesquisa.

* PVAe (Argissolo Vermelho-Amarelo Eutrófico Abrúptico); NXe + NCdcam (Nitossolo Háplico Eutroférrico Saprolitíco, Nitossolo Háplico Distrófico Cambissólico); LVAdf (Latossolo Vermelho-Amarelo Distroférrico Típico); GXe (Gleissolo Háplico Eutrófico); NXef + PVAe + NXe (Nitossolo Háplico Eutroférrico Saprolitíco, Argissolo Vermelho-Amarelo Eutrófico Abrúptico, Nitossolo Háplico Eutroférrico Saprolitíco); NXe + CXdlat (Nitossolo Háplico Eutroférrico Saprolitíco, Cambissolo Háplico Distrófico Latossólico); NXe + PVAe + CXbdlat + PAd + NXdcam (Nitossolo Háplico Distrófico Cambissólico, Argissolo Vermelho-Amarelo Eutrófico Abrúptico, Argissolo Amarelo Distrófico Latossólico, Nitossolo Háplico Eutrófico Saprolitíco).

A partir do MDEHC (Figura 5), foram obtidas novas informaçôes da área de estudo, interpolando-se cada célula da imagem; uma vez que a mesma contém informaçôes das altitudes numéricas. Sabe-se que o relevo tem significativa importância quanto à drenagem, já quesuas feiçôes determinam o comportamento do escoamento superficial e as áreas onde esse fluxo de água é acumulado. O MDEHC também mostra o contorno dos talvegues ali existentes. 


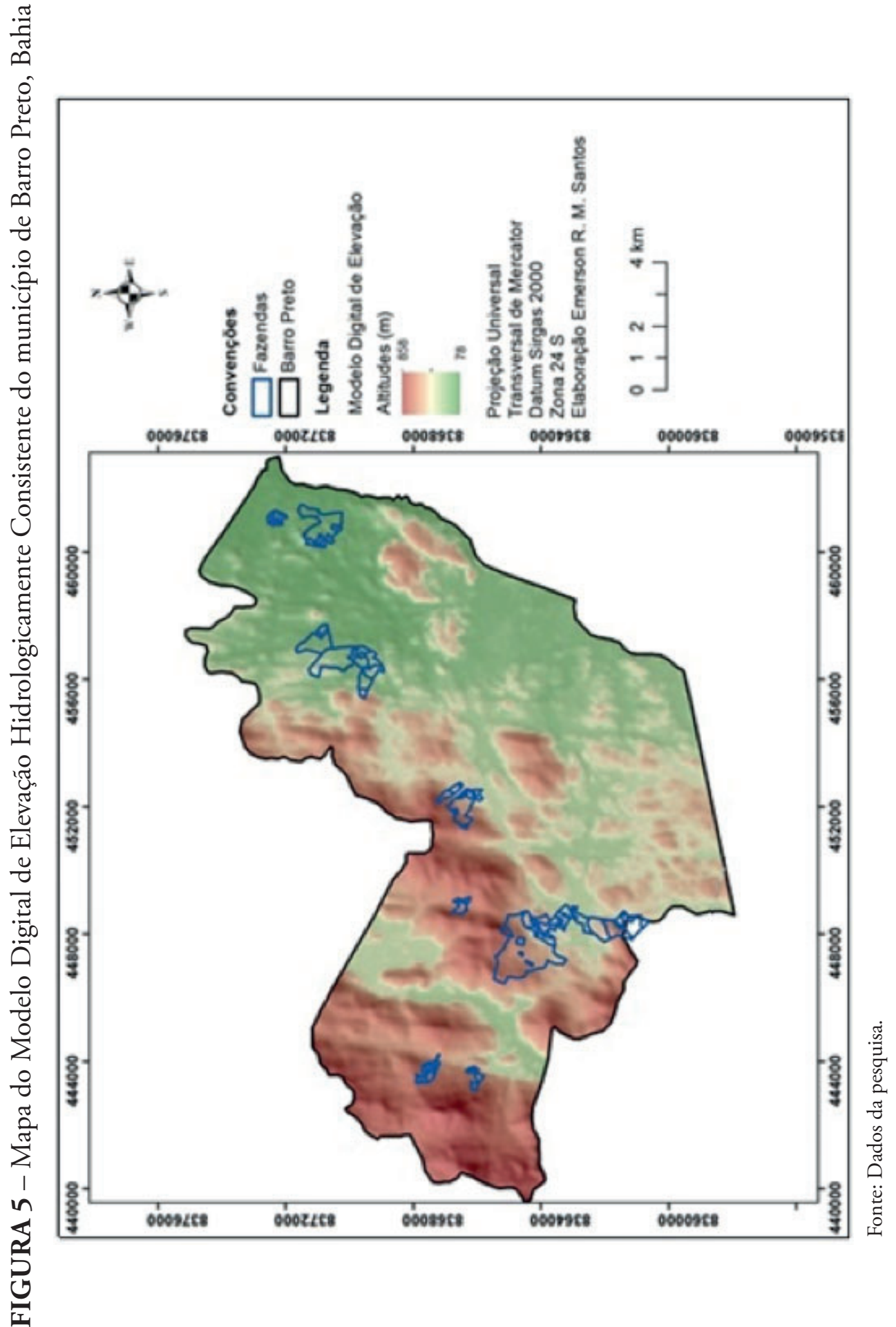




\section{Análise dos imóveis rurais quanto às condiçóes das áreas de nascentes e dos recursos hídricos}

Após a delimitação da drenagem numérica por meio do MDEHC, foram elaborados os mapas dos imóveis rurais (Figuras 6, 7 e 8), buscandose analisar o uso e ocupação do solo em conjunto com os vetores de fluxo de água e calhas fluviais.

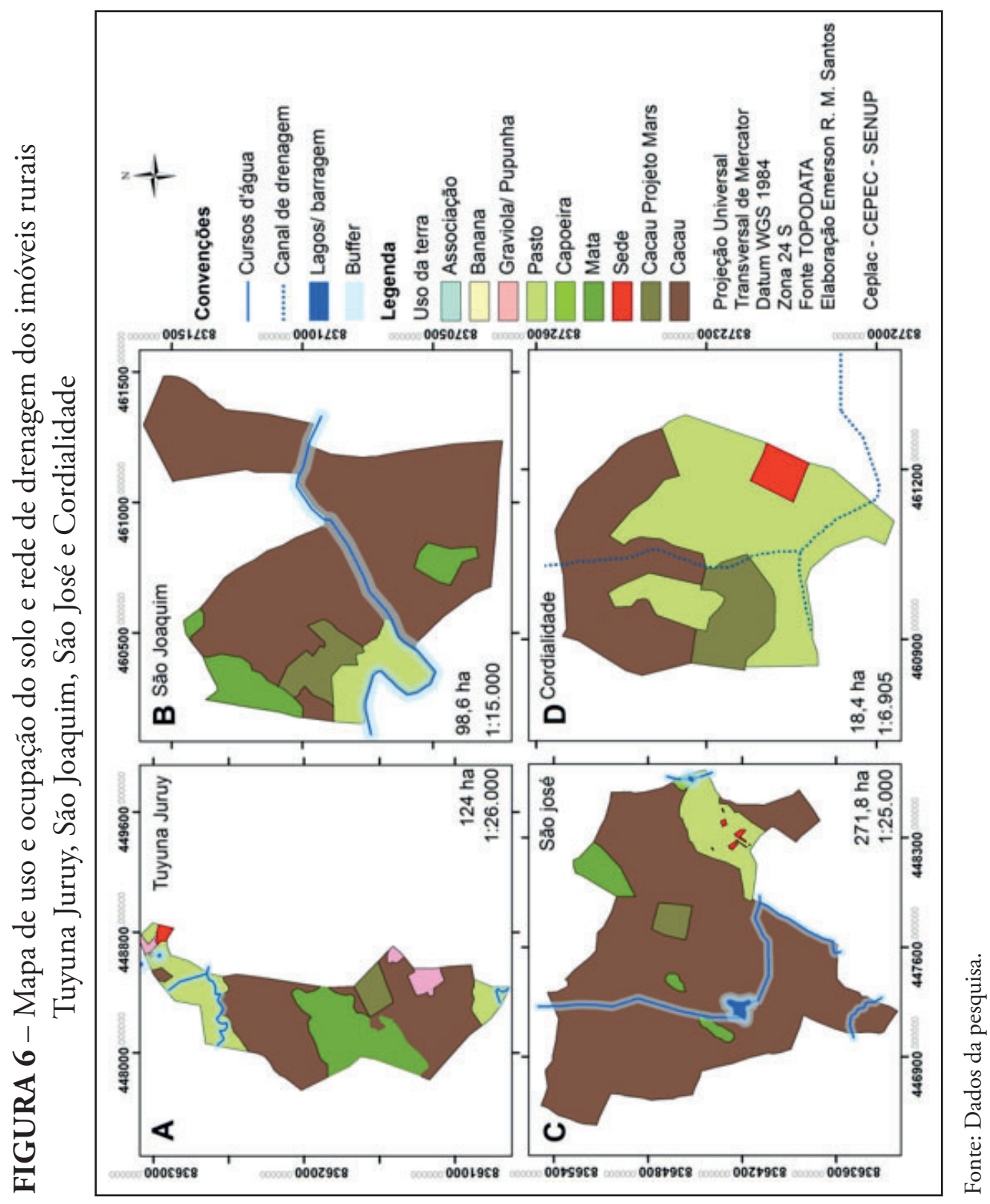


Ao norte da Fazenda Tuyuna Juruy (Figura 6-A), dois canais de escoamento cruzam uma área de pasto onde o solo tem uma grande tendência ao desencadeamento de processos erosivos pela presença apenas de gramíneas. Já a sul da fazenda é identificada outra área de pastagem, onde constata-se a mesma tendência dos outros dois canais. A criação de gado em pastagens mal conduzidas tende a aumentar o fluxo de escoamento, mesmo que intermitente, ocasionando erosáo laminar e em sulcos, podendo gerar ravinas e voçorocas que interferem significativamente na fertilidade e perda do solo, além de assoreamento em rios. No restante da propriedade rural, em seu trecho médio, observa-se a presença de remanescentes de Mata Atlântica e cultivo de cacau; e a sudeste, a cultura da pupunha, demonstrando uma boa proteção ao solo, além de um lago ao norte. Para o enquadramento deste imóvel nos aspectos legais do Código Florestal, é preciso revitalizar a vegetação em APP nas margens do rio e do lago.

A Fazenda São Joaquim (Figura 6-B) possui um canal a oeste, em uma área de pasto, e outro a leste, em uma área de cabruca. No restante deste imóvel, o que se observa são alguns fragmentos de Mata Atlântica ao norte e ao sul, e uma grande área de cultivo de cacau no sistema cabruca. Para adequar-se ao Código, este imóvel deve reflorestar suas APP à margem esquerda do rio, localizada a oeste da propriedade.

A Fazenda São José (Figura 6-C) tem, na porção norte, um canal de drenagem que segue em direçáo ao centro e desvia para o leste, além de outro canal a oeste do imóvel, ambos protegidos por áreas de cabruca. Vale destacar uma área a leste da fazenda, que é constituída por capoeira e pasto, onde se encontra um pequeno canal de drenagem que alimenta uma lagoa, o que requer cuidado com o seu manejo, pois representa uma importante fonte de água. No restante do imóvel há boa cobertura vegetal, em função da intensa presença de cabruca e alguns fragmentos de mata. A única área indicada para reflorestamento corresponde justamente às pastagens da porção leste da fazenda.

A Fazenda Cordialidade (Figura 6-D) apresenta uma grande proporção de pastagens em relação à sua área e às outras propriedades do município. Destaca-se um canal de drenagem ao sul deste imóvel rural, que não foi visualizado na fotointerpretação, mas foi identificado pelo modelo digital de elevaçáo, que cruza uma área de pasto e precisa de grande atenção por parte do proprietário quanto ao seu manejo, pois condiçóes como estas podem provocar prejuízos financeiros e ambientais, além da possibilidade de ser um curso d'água intermitente, sendo a pastagem um dos grandes 
responsáveis por este regime. É indicada uma recuperação desta área, o que poderá influenciar positivamente na infiltração e recarga hídrica, auxiliando na volta de um regime perene a este curso. Por sua vez, o canal de drenagem que corta a fazenda de norte a sul encontra-se, em grande parte, sob cabruca, mas requer a recuperação das faixas de APP no seu percurso em áreas de pastagem.

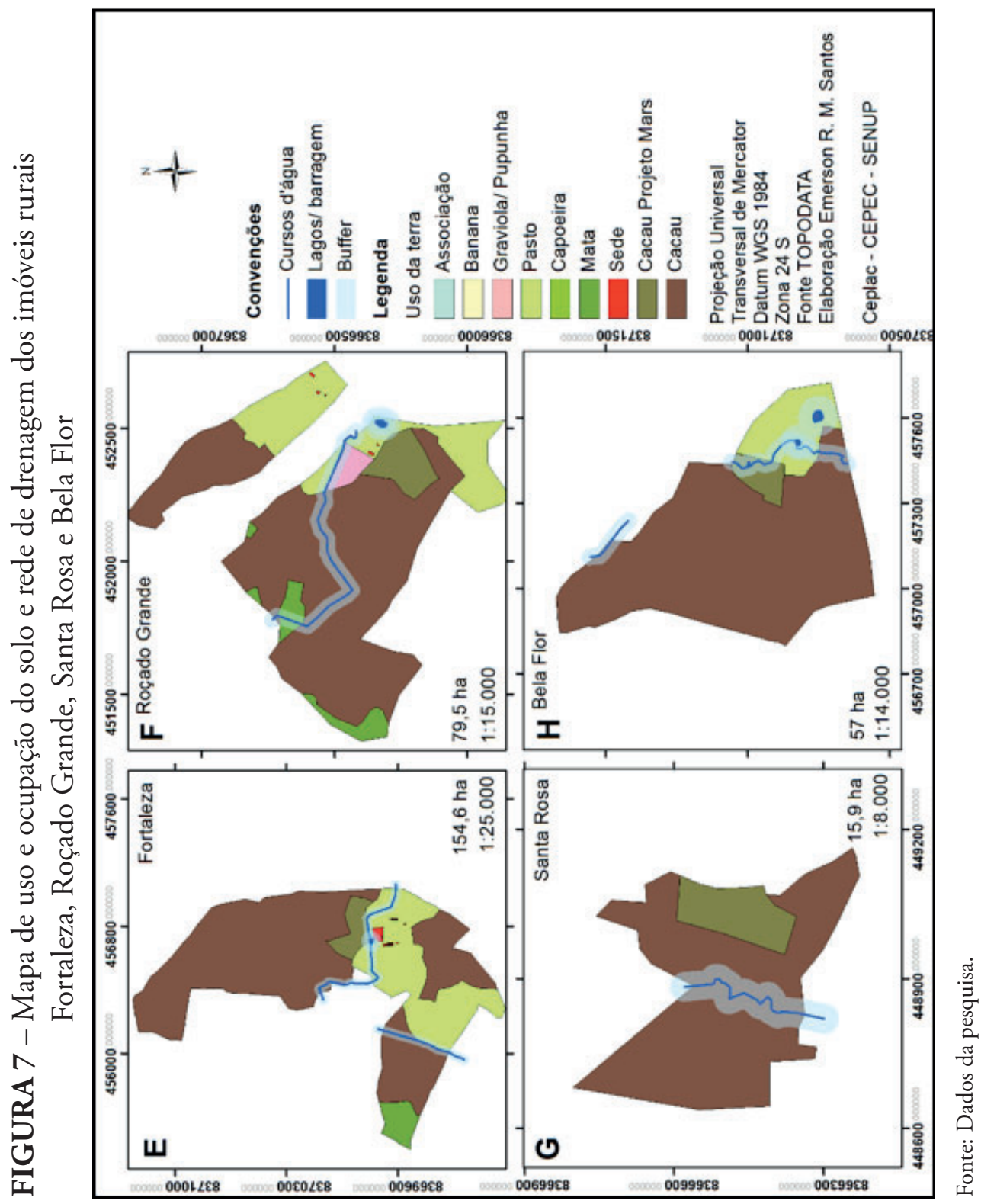


A Fazenda Fortaleza (Figura 7-E) tem grande parte de seu território dedicado à produção de cacau, mas ainda assim possui um pequeno fragmento de Mata Atlântica a oeste. No entanto, um dos cursos d'água também atravessa uma área de pasto e necessita de cuidados especiais quanto ao seu manejo, além do reflorestamento da mata ciliar.

A Fazenda Roçado Grande (Figura 7-F) apresenta um curso d'água que atravessa um fragmento de mata e segue em direçáo à cabruca. Também se destaca uma pequena lagoa próxima à sede da fazenda que deve ter seu entorno reflorestado, assim como as margens do rio no trecho em que atravessa as áreas de pasto.

A Fazenda Santa Rosa (Figura 7-G) dedica todo seu território à produçáo de cacau e possui um rio que corta seu território de norte a sul. $\mathrm{O}$ enquadramento aos requisitos impostos pelo Código é viável, uma vez que a APP em torno desse rio encontra-se bem preservada.

A Fazenda Bela Flor (Figura 7-H) tem grande parte de seu território dedicado ao cultivo do cacau no sistema cabruca. Na porção sudeste, entretanto, nota-se o uso de pastagens nas proximidades de um rio, assim como uma barragem e uma lagoa, uma combinação que pode trazer ao produtor muita perda de solo produtivo, se mal manejado. Assim, recomenda-se a recuperação das margens do rio, da barragem e da lagoa.

$\mathrm{Na}$ Fazenda Bom Jesus (Figura 8-I) existe uma grande diversificação quanto ao uso do solo, com cultivos de cacau, banana e graviola. Na porção norte da fazenda existe um grande fragmento de mata em bom estado de conservaçáo e duas áreas menores em processo de regeneração. Para se tornar uma propriedade produtora de água, é necessário o reflorestamento das três nascentes identificadas em áreas de cacau, além das margens do rio que cruza um trecho de pastagem.

$\mathrm{Na}$ Fazenda Bela Cruz (Figura 8-J) predomina o cultivo do cacau no sistema cabruca, por onde percorrem os dois rios ali existentes, cujas margens encontram-se em bom estado de conservação. Este fato contribui para que o imóvel em questão seja enquadrado no Programa Produtor de Água.

A Fazenda Nova Harmonia (Figura 8-L) tem a maior parte de seu território destinado à produçáo de cacau, com uma mancha de mata em sua porção central e duas áreas em processo de regeneração a sul e sudeste respectivamente. Foram identificadas duas áreas que merecem destaque: a primeira, onde se encontra um rio protegido pela cabruca; e a segunda, onde foi identificada uma lagoa em área de pastagem. Para o atendimento aos requisitos estabelecidos pelo Código, é necessária a revitalização do entorno da lagoa num raio de $50 \mathrm{~m}$. 
Náo obstante, as condiçóes ambientais privilegiadas propiciadas pelo sistema agroflorestal cacau-cabruca, de modo geral, serão necessárias providências por parte dos fazendeiros para o cumprimento integral dos requisitos legais previstos no Código Florestal, tais como o reflorestamento das Áreas de Preservação Permanente e a implementação de Reserva Legal.

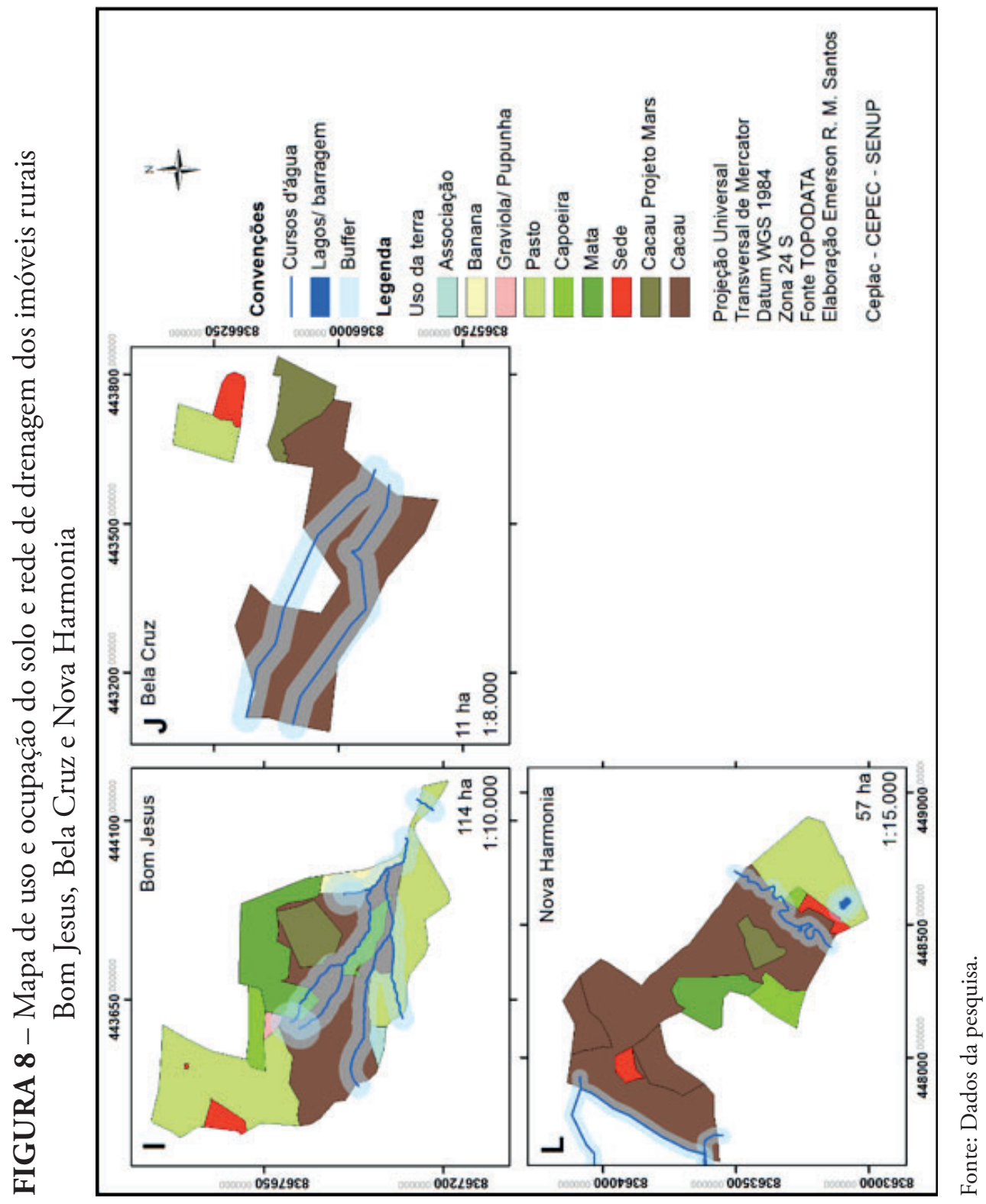




\section{Comentários Finais}

De modo geral, os imóveis rurais analisados apresentam boa cobertura florestal em razão da predominância da cacauicultura; porém, nas situações de cultivo de pastagens, há necessidade de maior atenção às práticas conservacionistas e observância à legislação ambiental.

Nas condiçôes registradas neste trabalho, todos os imóveis atendem requisitos básicos para seu enquadramento como candidatos a Produtor de Água; no entanto, ainda assim são necessárias práticas de recuperação de Áreas de Preservação Permanente em pastagens nas Fazendas Tuyuna Juruy, São Joaquim, Cordialidade, Fortaleza, Roçado Grande, Bela Flor, Bom Jesus e Nova Harmonia. 


\section{Referências}

AGÊNCIA NACIONAL DAS ÁGUAS - ANA. Programa produtor de águas. 2012. Disponível em:< http://produtordeagua.ana.gov.br/>. Acesso em: 24 ago. 2015.

BARRETO, A. C. F. et al. Fracionamento físico e químico de carbono orgânico total em um solo de mata submetido a diferentes usos. Revista Brasileira de Ciência do Solo, Viçosa, MG, v. 32, p. 1471-1478, 2008.

BRASIL. Lei 12.651, de 25 de maio de 2012. Dispóe sobre o Novo Código Florestal Brasileiro. Disponível em: http://www.planalto.gov.br/ccivil_03/_ato2011-2014/2012/lei/l12651.htm. Acesso em: 24 jun. 2015.

CÂMARA, G.; MEDEIROS, J. S. Geoprocessamento para projetos ambientais. São José dos Campos, SP: INPE, 1996.

THE CGIAR CONSORTIUM FOR SPATIAL INFORMATION CGIAR-CSI. SRTM Data. 2004. Disponível em: <http://srtm.csi.cgiar. org/SELECTION/inputCoord.asp >. Acesso em:10 ago. 2014.

COSTA, T. C. C.; SOUZA, M. G.; BRITES, R. S. Delimitação e caracterização de áreas de preservaçáo permanente por meio de um Sistema de Informaçôes Geográficas (SIG). Revista Árvore, Viçosa, MG, v. 20, n. 1, p. 129-135, 1996.

INÁCIO, E. S. B. et al. Quantificação da erosão em sistema agroflorestal e pastagem na região sul da Bahia. Caatinga, Mossoró, RN, v. 18, p. 238-244, 2005.

OLIVEIRA, M. J. Proposta metodológica para delimitaçáo automática de Áreas de Preservaçáo Permanente em topos de morro e em linha de cumeada. 2002. 53 f. Dissertação (Mestrado em Ciência Florestal) - Universidade Federal de Viçosa, Viçosa, MG, 2002.

PAIVA, A. Q.; ARAUJO, Q. R. Fundamentos do manejo e da conservação dos solos na região produtora de cacau da Bahia. In: VALLE, R. R. Ciência, tecnologia e manejo do cacaueiro. 2. ed. Brasília, DF: Ministério da Agricultura, Pecuária e Abastecimento, 2012. p. 115-134.

PIMENTEL, D. et al. Conserving biological diversity in agricultural/ forestry systems. BioScience, Uberlândia, MG, v. 42, n. 5, p. 354-362, 1992. 
REITSMA, R.; PARRISH, J. D.; McLARNEY, W.. The role of cacao plantations in maintaining forest avian diversity in southeastern Costa Rica.

Agroforestry Systems, v. 53, p. 185-193, 2001.

SUPERINTENDÊNCIA DE ESTUDOS ECONÔMICOS E SOCIAIS DA BAHIA - SEI. Base cartográfica digital do Estado da Bahia. Mapeamento topográfico sistemático 1:100.000. Salvador: SEI, 2006.

SOARES, V. P. et al. Avaliação das áreas de uso indevido da terra em uma micro-bacia no município de Viçosa, MG, através de fotografias aéreas e Sistemas de Informação Geográfica. Revista Árvore, Viçosa, MG, v. 26, n. 2, p. 243-251, 2002.

SPERBER, C. F. S. et al. Tree species richness and density affect parasitoid diversity in cacao agroforestry. Basic and Applied Ecology, v. 5, n. 3, p. 241-251, 2004.

TUNDISI, J. G. Limnologia do século XXI: perspectivas e desafios.

São Carlos: Suprema Gráfica e Editora, 1999. 24 p. 


\title{
Caracterizaçáo hidrológica e biogeoquímica de nitrogênio em microbacias: estudo de caso em áreas com diferentes usos do solo
}

\author{
Daniela Mariano Lopes da Silva \\ Marilane Andrade Pereira \\ Eline Nayara Dantas da Costa \\ Jéssica Carneiro de Souza
}

\section{Introdução}

A bacia hidrográfica é a unidade territorial básica em estudos sobre a ciclagem de nutrientes. As duas principais condiçóes para um elemento químico ser transportado em uma bacia são a disponibilidade de material e energia disponível para esse transporte, tal como o fluxo. Ambos, especialmente este último, são controlados por fatores externos da paisagem e, por essa razão, mudanças no uso e ocupaçáo do solo alteram a estrutura e funcionamento dos ecossistemas ali existentes (FISHER; SPONSELER; HEFFERNAN, 2004).

A substituição das florestas por outros tipos de cultivos resulta em perdas significativas de nutrientes e matéria orgânica que podem contribuir para o aumento ou redução dessas formas nos corpos d'água.

O entendimento sobre os processos da dinâmica de nutrientes é fundamental para o manejo adequado em regióes tropicais em virtude da baixa fertilidade dos solos nesses ambientes. A ciclagem de nutrientes é um processo ecológico importante que envolve a ciclagem de elementos entre os compartimentos bióticos e geoquímicos dos ecossistemas. A produtividade dos ecossistemas terrestres é limitada por nitrogênio, ocasionando uma baixa disponibilidade desse elemento no solo e, consequentemente, uma redução na exportação de nitrogênio nos sistemas aquáticos (SUDDUTH et al., 2013; OZIEGBE; MUOGHAL; OKE, 2011). 
Muitos estudos em diferentes partes do mundo abordam a relação entre ciclagem de nutrientes e as vias hidrológicas, demonstrando o papel e a importância dessa interação para os ecossistemas florestais (VELTHORST; BREEMEN, 1989; RODÁ; AVILA; BONILLA, 1990; McCUNE; BOYCE, 1992; LEVIA JUNIOR; FROST, 2003).

A composição da água da chuva é alterada ao atravessar o dossel florestal (PARKER, 1983). Desta forma, a precipitação é uma fonte indispensável na ciclagem de nutrientes, pois transfere os íons da copa e tronco das árvores para o solo via precipitação interna e escoamento pelo tronco (CATRIONA et al., 2012). Em média, 98\% do total de entrada de nutrientes em uma floresta advêm das chuvas, sendo 38\% provenientes da deposição e $62 \%$ lixiviados das copas das árvores (TOBÓN; SEVINK; VERSTRATEN, 2004). Estudos têm demonstrado a importância dessas vias na ciclagem de nitrogênio.

A conversão de florestas em diferentes sistemas de cultivo ou áreas urbanizadas tem afetado a dinâmica desse nutriente, ocasionando, na maioria dos casos, um aumento do seu fluxo para os rios e riachos (GERMER et al., 2007; JICKELLS et al., 2013; SALEMI et al., 2015).

No Brasil, a maioria dos estudos envolvendo a ciclagem de nutrientes em microbacias tem sido realizada na Amazônia (GERMER et al., 2007; CHAVES et al., 2009; NEILL et al., 2001, 2011; DEEGAN et al., 2011); Cerrado (PARRON; BUSTAMANTE; MARKEWITZ, 2011) e na Mata Atlântica no sudeste brasileiro (ANDRADE et al, 2011; SALEMI et al., 2013, 2015). Mas, sobre as microbacias na Mata Atlântica no nordeste do país, pouco se sabe a respeito da influência dos diferentes usos do solo na ciclagem de nutrientes.

A Mata Atlântica é formada por um conjunto de ecossistemas que ocupa uma extensa faixa da costa brasileira, estendendo-se do Sul ao Nordeste, entre os estados do Rio Grande do Sul e Piauí. É considerada um dos biomas mais ricos da Terra, porém um dos mais ameaçados de extinção (GALINDO-LEAL; CÂMARA, 2005; FUNDAÇÃO SOS MATA ATLÂNTICA, 2013). Devido à sua dimensão, ela é formada por ecossistemas bastante diferenciados, caracterizados principalmente pelas condiçóes locais de clima e relevo (BRASIL. MDA, 2008).

Em dois anos, identificou-se que 21.977 ha de Mata Atlântica foram desmatados em 17 estados da federação e que, no último levantamento sobre remanescentes, houve um aumento de $29 \%$ da taxa de desmatamento. No entanto, na região Sul da Bahia, não foi possível constatar o atual avanço, 
em função da baixa disponibilidade de imagens de satélite de boa qualidade e sem cobertura de nuvens (FUNDAÇÃO SOS MATA ATLÂNTICA, 2013).

O uso da Mata Atlântica para implantação do sistema cacau-cabruca foi, por mais de 250 anos, uma "solução" para a conservação desse bioma no Sul da Bahia (SAMBUICHI, 2003). A região cacaueira do Sul da Bahia está inserida no corredor central da Mata Atlântica (LOBÃO; VALERI, 2009), e parte do seu cultivo foi estabelecido sob a floresta nativa a partir da retirada do sub-bosque e introdução da espécie Theobroma cacao L. (LOBÃO et al., 1997; LOBÃO; SETENTA; VALLE, 2004).

O sistema cacau-cabruca pode ser conceituado como sistema agrossilvicultural ou agroflorestal, sendo provavelmente o primeiro sistema agrossilvicultural dos trópicos (LOBÃO; SETENTA; VALLE, 2004). "Cabruca" é um termo modificado do verbo brocar, que originou as palavras cabrocar ou cabrucar, que significa remover algumas plantas do sub-bosque para plantar o cacaueiro (LOBÃO; SETENTA; VALLE, 2004; LOBÃO et al., 2007). O cacaueiro é plantado de forma descontínua sob a sombra das árvores da floresta (estrato dominante e codominante) e é rodeado por vegetação natural, causando menor impacto aos recursos naturais com ele relacionados (LOBÃO; SETENTA; VALLE, 2004).

Quando comparado a outros sistemas agrícolas, esse sistema agroflorestal favoreceu a conservação de áreas com remanescentes florestais da Mata Atlântica, promovendo a conservação de indivíduos arbóreos, além de proporcionar condiçóes microclimáticas adequadas ao aumento da densidade de plantas com elevada significância econômica, social e ecológica (SAMBUICHI, 2002; LOBÃO; SETENTA; VALLE, 2004).

Entre outros benefícios promovidos por ele, destaca-se a formação do maior banco genético para espécies de madeira nobre. A cabruca representa um importante habitat de muitas espécies vegetais ornamentais (epífitas, orquídeas e bromélias) e animais (aves e mamíferos). E para esses últimos, funciona, principalmente, como corredor ecológico, onde podem se reproduzir, garantindo assim a conservação da biodiversidade (SAMBUICHI, 2002, 2006).

Diferente de outros cultivos agrícolas, esse sistema agroflorestal promove menor impacto sobre a qualidade dos solos, deixando-os similares ao de uma floresta nativa, reduzindo a lixiviaçáo de diversos nutrientes e íons maiores e preservando os recursos hídricos presentes na área (LOBÃO; SETENTA; VALLE, 2004). 
Levando em consideração a complexidade dos fatores que condicionam a ciclagem do nitrogênio dissolvido em uma determinada área e a sua dinâmica no meio ambiente, este capítulo apresenta os resultados de uma pesquisa cujo principal objetivo é calcular o balanço de nitrogênio orgânico e inorgânico dissolvido nas vias hidrológicas e em um rio de duas microbacias com diferentes usos do solo: floresta em regeneração e sistema agroflorestal cacau-cabruca.

\section{Caracterização das microbacias}

De acordo com o sistema de classificação Köppen, as microbacias estáo inseridas no clima tipo Af (clima quente e úmido, sem estaçáo seca definida), com temperatura média anual de $26^{\circ} \mathrm{C}$ e amplitude térmica variando de $10^{\circ}$ a $14^{\circ} \mathrm{C}$. A regiáo apresenta precipitação média anual de $1.800 \mathrm{~mm}$ a $2.200 \mathrm{~mm}$ (LANDAU, 2003), bem distribuída durante o ano, e, muitas vezes, umidade relativa do ar acima de 80\% (ASMAR; ANDRADE, 1977; SÁ, 1982)

Foram avaliadas duas áreas: a primeira, inserida em uma área de floresta em regeneração; e a segunda, em uma área de sistema agroflorestal cacau-cabruca.

A microbacia 1 está localizada no Parque Estadual da Serra do Conduru, no município de Uruçuca, entre as coordenadas UTM 0492289 W e 8401012 S, e é composta por um mosaico de florestas em diferentes fases de regeneração (MARTINI, 2007) (Figura 1). A vegetação local é classificada como Floresta Ombrófila Sub-montana Densa, de acordo com o Sistema Brasileiro de Classificação da Vegetação do Instituto Brasileiro de Geografia e Estatística (IBGE, 1992), ou Floresta Tropical Úmida, de acordo com o Sistema Holdridge de Classificação da Vegetação (HARTSHORN, 1991). Possui um dossel uniforme, acima de $25 \mathrm{~m}$ de altura, com poucos indivíduos emergentes, muitas epífitas, grandes cipós e um sub-bosque denso (JARDIM, 2003).

O tipo de solo predominante corresponde ao Latossolo Vermelho-Amarelo de coloração Vermelho-Amarelo Distroférrico Típico Petroplíntico. A composição físico-química é predominantemente arenosa, distribuída em $50 \%$ de areia, $34 \%$ de silte e $16 \%$ de argila.

Essa microbacia possui uma área de 36,08 ha com vazáo de aproximadamente $0,59 \pm 22,9 \mathrm{~L} / \mathrm{s}$ (SILVA, 2012), e os valores de $\mathrm{pH}$ da água variam de $6,3 \pm 0,4$; e de condutividade elétrica, de $42,5 \pm 5,1 \mu \mathrm{S} \mathrm{cm}^{-1}$. 
A microbacia 2 está localizada na Fazenda Santa Cruz, em Ilhéus, entre as coordenadas UTM 481891,62 W e 8393232,29 S (Figura 1). Está inserida em uma área com a presença do sistema agroflorestal cacau-cabruca, com declividade em torno de $5 \%$ e sombreamento médio de 70\%, formado por cacaueiros (Theobroma cacao L.), jaqueiras (Artocarpus heterophylla Lam. ), cajazeiras (Spondias lutea L.), eritrinas (Erythrina sp), imbaúbas (Cecropia leucocoma Miq.) e jequitibás (Cariniana sp), dentre outras espécies (ARGÔLO, 2009).

Devido à influência do domínio dos sedimentos terciários do Grupo Barreiras, o tipo de solo predominante é o Argissolo Amarelo Distrófico típico a moderado, com textura média argilosa, (FERNANDES, 2008). O manejo agrícola nessas áreas envolve a adubação, calagem e uso de inseticidas (SAMBUICHI, 2002). No entanto, na área estudada, atualmente são realizados apenas as podas, corte da vegetação e poucos eventos de calagem para correção do solo.

Essa microbacia abrange uma área de 73,38 ha, com valores de $\mathrm{pH}$ da água em torno de 5,8 $\pm 0,1$ e condutividade elétrica de $102 \pm 18,6 \mu \mathrm{S} \mathrm{cm}^{-1}$.

FIGURA 1 - Localização dos pontos de coleta - área de floresta (A) e área no sistema cacau-cabruca (B)

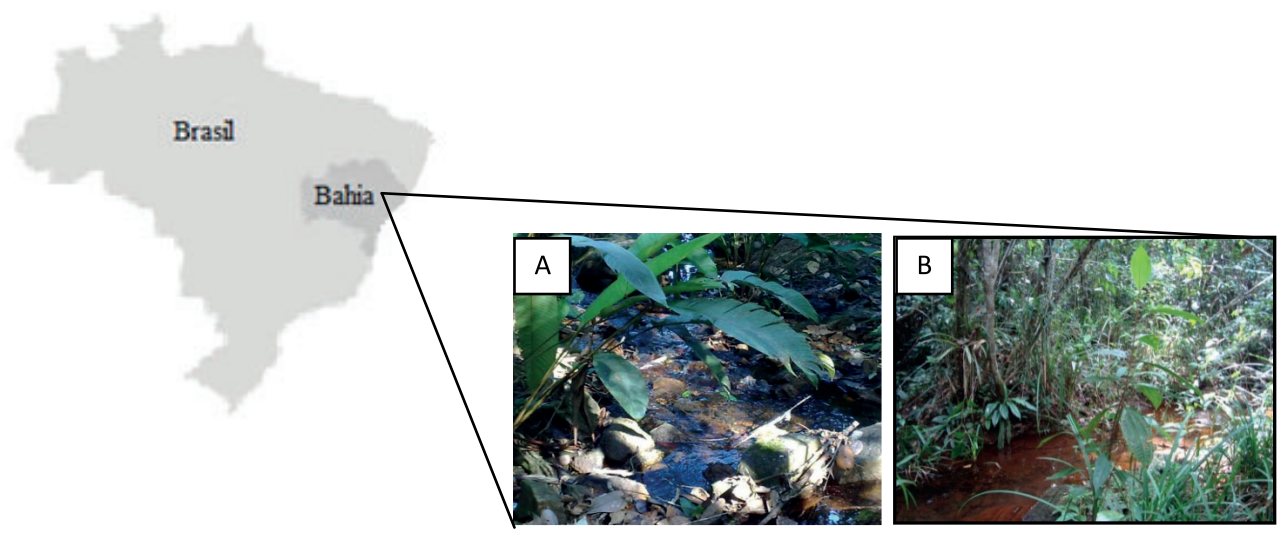

Fonte: Dados da pesquisa.

\section{Métodos e Técnicas de Pesquisa em Vias Hidrológicas}

As vias estudadas foram precipitaçáo, precipitação interna, escoamento pelo tronco e água superficial. 


\section{Coleta de dados}

Nas duas microbacias, foram instalados coletores específicos para cada tipo de via analisada, sendo dispostos paralelos aos rios. Foram fixados, em cada microbacia, dez coletores para precipitação interna, três coletores para a precipitaçáo e quatro para escoamento pelo tronco. Todos foram dispostos nas margens dos rios de maneira similar. Com relaçáo à água superficial, foi estabelecido um ponto de amostragem nos rios onde as coletas foram feitas manualmente. As amostras foram coletadas semanalmente, de setembro a dezembro de 2012, num período de 11 semanas.

Para a coleta de Precipitação (P) e Precipitação Interna (PI), foram instalados coletores nas duas microbacias. Um coletor foi instalado em uma clareira onde não havia interferência das árvores para medir a P; e o outro, em um local abaixo da copa das árvores para medir a PI. Os coletores foram confeccionados com tubos de PVC de $150 \mathrm{~cm}$ de largura e 15 $\mathrm{cm}$ de diâmetro, fixados a $1 \mathrm{~m}$ acima do solo. Para a coleta da água, foi feita uma abertura de $10 \mathrm{~cm}$ x 1,40 m em um dos lados do cano. Em uma de suas extremidades foi acoplado um funil com uma mangueira ligada a frascos de $10 \mathrm{~L}$, e na base desse funil foi fixada uma malha para impedir a passagem de galhos, folhas e animais (Figuras 2A e 2B).

Para captar a água que escoa pelo tronco, foi necessário fixar uma mangueira plástica com espuma expansiva de poliuretano ao redor das árvores selecionadas. Esta mangueira foi colocada a $1 \mathrm{~m}$ acima do solo e estava ligada a um galáo com $5 \mathrm{~L}$ de capacidade, cuja função é desviar o Escoamento pelo Tronco (ET) para um recipiente fechado, onde é mantido até o momento da coleta (Figura 2C). Para a instalaçáo dos coletores, foi estabelecida uma parcela de $10 \times 10 \mathrm{~m}$ em um dos lados do riacho. $\mathrm{O}$ critério para a seleção das árvores foi possuir o tronco com o DAP $\geq 15 \mathrm{~cm}$ de diâmetro. Assim, quatro réplicas foram instaladas na microbacia com floresta; e outras quatro, na microbacia com sistema agroflorestal cacaucabruca. As amostras de água do rio (R) foram coletadas manualmente através de seringas de $60 \mathrm{~mL}$. Para cada evento semanal, foi coletada uma amostra. 
FIGURA 2 - Coletores de precipitação (A), precipitação interna (B) e escoamento pelo tronco $(\mathrm{C})$ instalados nas áreas de estudo

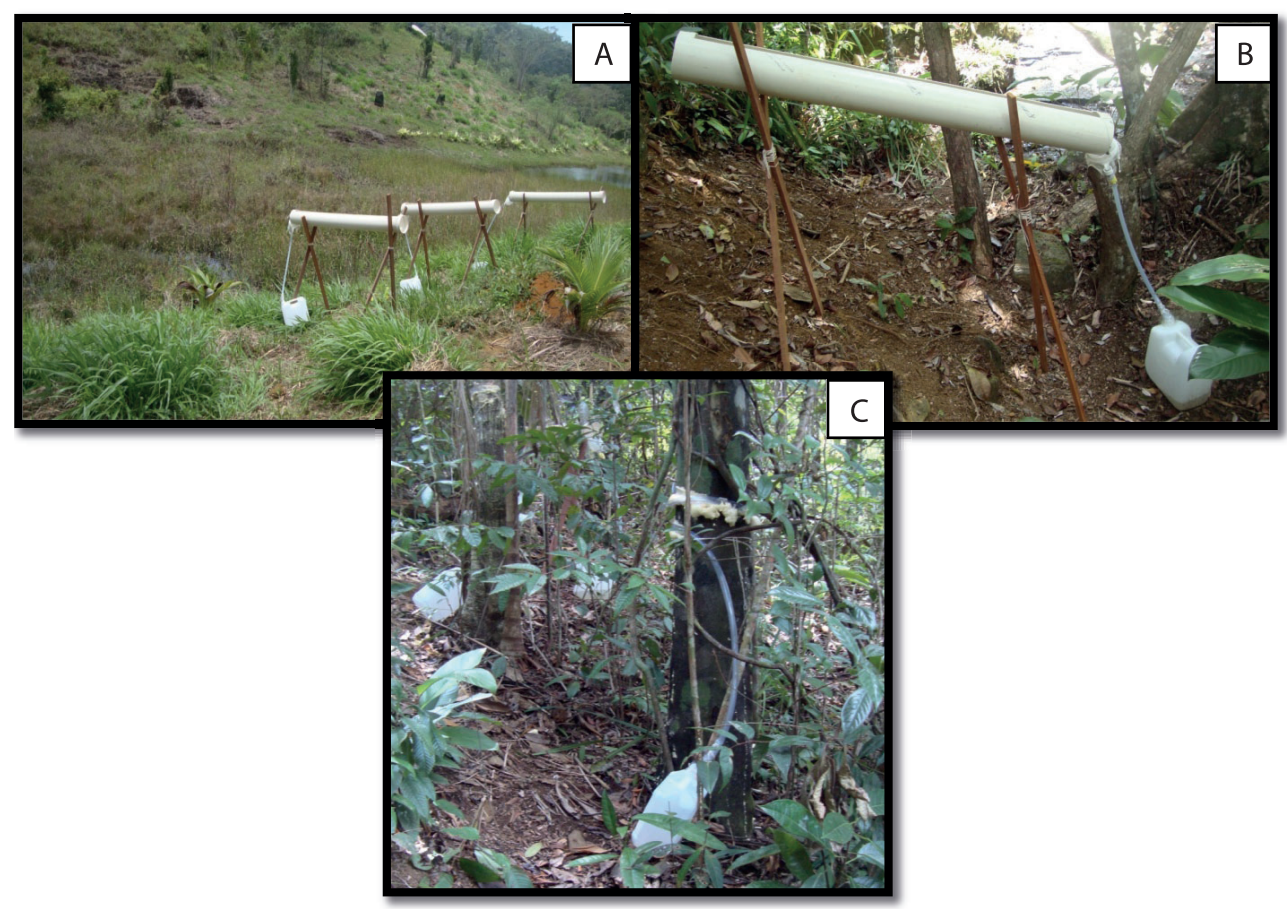

Fonte: Dados da pesquisa.

Análise dos dados

Para todas as vias hidrológicas estudadas, o total das chuvas foi recolhido dos coletores e medido o volume para posterior correção das concentraçóes. Em campo, todas as amostras foram coletadas por meio de uma seringa de $60 \mathrm{~mL}$ e filtradas em membrana de microfibra de vidro com porosidade de $0,7 \mu \mathrm{m}$, calcinadas a $450^{\circ} \mathrm{C}$ por um período de 4 horas. As amostras foram armazenadas em frascos de polietileno de alta densidade, congelados até a análise do material. As formas de Nitrogênio Inorgânico Dissolvido ( $\mathrm{NID}=\mathrm{NO}_{3}{ }^{-}+\mathrm{NH}_{4}{ }^{+}+\mathrm{NO}_{2}{ }^{-}$) foram determinadas por cromatografia iônica (DIONEX ICS1000) e o Nitrogênio Dissolvido Total (NDT) foi determinado através da digestão por Persulfato de Potássio e Espectrofotometria no VIS, de acordo com Grasshoff, Erhardt e Kremling (1983). O Nitrogênio Orgânico Dissolvido foi determinado pela diferença entre NDT e as formas inorgânicas $\mathrm{NO}_{3}{ }^{-}+\mathrm{NH}_{4}^{+}+\mathrm{NO}_{2}^{-}$. 
Para calcular as concentrações em Média Ponderada por Volume (MPV), os volumes acumulados em cada coletor foram inicialmente transformados em milímetros ( $\mathrm{mm}$ ), como mostra a Equação 1. Assim, o volume em litros de cada via foi dividido pela área do seu respectivo coletor.

$$
\mathrm{V}(\mathrm{mm})=\frac{\mathrm{V}(\mathrm{L})}{\mathrm{A}(\mathrm{ha})}
$$

Devido às diluiçóes diferentes das amostras ocasionadas pelas diferenças no volume de chuva precipitado nas distintas vias, as concentraçóes (mm) das vias P, PI, e ET foram padronizadas em MPV. Isto limita a ocorrência de concentraçôes muito altas em vias com maior volume recolhido ou concentraçóes muito baixas em vias de menor volume acumulado, como mostra a Equação 2:

$$
[\mathrm{x}] \mathrm{MPV}=\frac{\left([\mathrm{x}]_{1}\right.}{\left.* \mathrm{~V}_{1}\right)+\left([\mathrm{x}]_{2}\right.} \frac{\left.* \mathrm{~V}_{2}\right) \ldots\left([\mathrm{x}]_{\underline{n}}\right.}{\left(\mathrm{V}_{1}+\mathrm{V} 2 \ldots+\mathrm{V}_{\underline{n}}\right)}
$$

Em que: se divide o somatório das concentrações de cada espécie ([X]) nas amostras, multiplicado por seu respectivo volume (V), pelo somatório do volume total de todas as amostras.

Para se calcular o balanço de um elemento em uma bacia, são levadas em consideração as entradas e saídas do sistema. Geralmente a entrada se dá pela precipitação, e as saídas são as descargas dos rios, infiltração até as águas subterrâneas, absorção e respiração, tanto das plantas como também do solo. Porém, para calcular o balanço de Nitrogênio, foram analisadas as suas vias hidrológicas de transporte rápido. Logo, estabeleceu-se como entrada a precipitaçáo; e como saída, a descarga pelos rios. Deste modo, o balanço de massa foi calculado usando a Equação 3:

Balanço $=$ Entrada - Saída, ou seja, Balanço $=($ Precipitaçáo - Riacho $)$

Em que:

Entrada $=$ Fluxo de entrada pela precipitaçáo, expresso em $(\mu \mathrm{M}$ em MPV)

Saída = Fluxo de saída pela água do riacho, expresso em $(\mu \mathrm{M})$ 
Para verificar se o conjunto de dados obedece a uma distribuiçáo normal, foi aplicado o teste Kormogorov-Smirnov $(\mathrm{p}<0,05)$. Pelo fato de os dados não seguirem uma distribuição normal, foram empregados testes estatísticos não paramétricos. Para a avaliação da variação de Nitrogênio entre as vias hidrológicas, aplicou-se a Análise de Variância Kruskal-Wallis $(\mathrm{p}<0,05)$; e, para estabelecer se havia diferença entre as áreas, foi aplicado o teste não paramétrico Wilcoxon Mann Whitney $(\mathrm{p}<0,05)$.

\section{Balanço de Nitrogênio nas microbacias de floresta e sistema cacau-cabruca}

A assimilação e transformação de Nitrogênio em muitas bacias ocorre primariamente no ecossistema terrestre e, consequentemente, os valores de Nitrogênio encontrados nos rios são o reflexo dos processos que ocorrem nesse compartimento (SUDDUTH; PERAKIS; BERNHARDT, 2013). O transporte de Nitrogênio ao longo das vias hidrológicas apresentou comportamento diferente entre as duas bacias estudadas.

A principal forma da substância encontrada (em ambas as microbacias e vias hidrológicas) foi o Nitrogênio Orgânico Dissolvido (NOD), apresentando balanços positivos nas duas áreas estudadas (Figura 3 e 4). Em relação ao $\mathrm{NO}_{3}^{-}$e $\mathrm{NH}_{4}^{+}$, foram encontrados padróes distintos, sendo as entradas maiores que as saídas para o $\mathrm{NO}_{3}^{-}$, e as entradas menores que as saídas para o $\mathrm{NH}_{4}^{+}$. 
FIGURA 3 - Porcentagens das diferentes formas de Nitrogênio na área de estudo

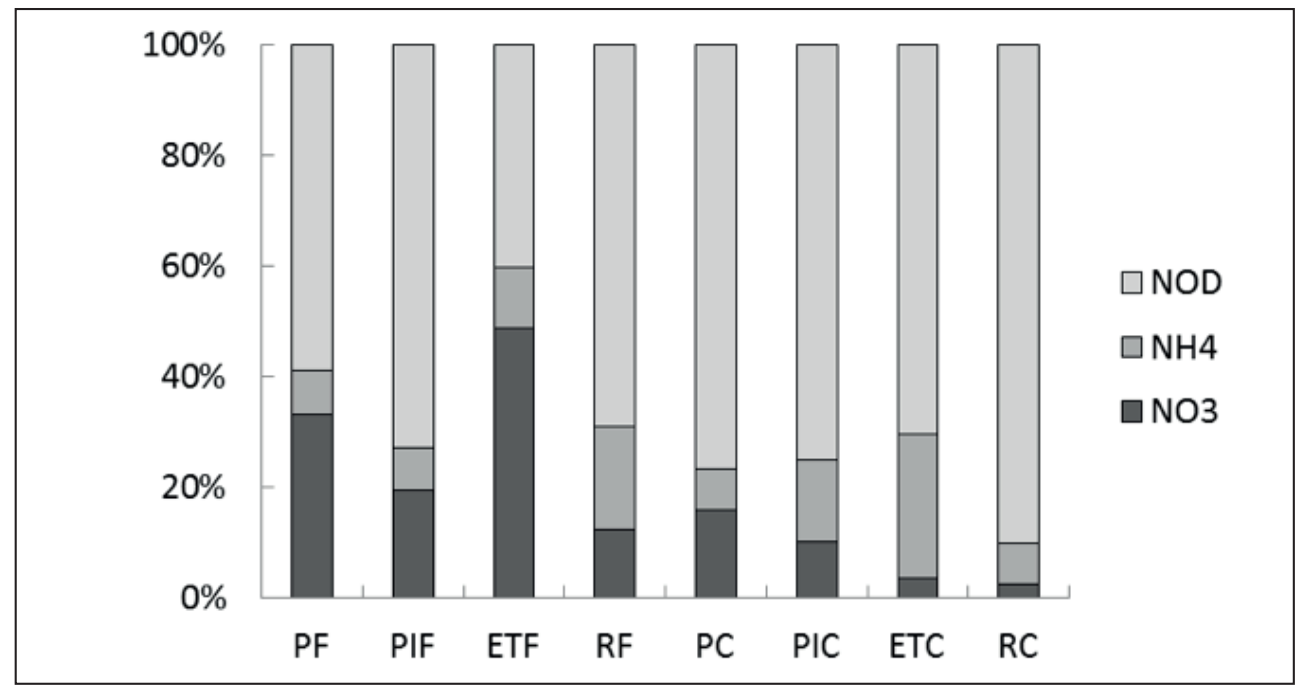

* Nas áreas de floresta: PF - Precipitação Floresta, PIF - Precipitação Interna Floresta, ETF - Escoamento pelo Tronco Floresta, RF - Riacho Floresta.

No sistema cacau-cabruca: PC - Precipitação Sistema Cacau-Cabruca, PIC - Precipitaçáo Interna Sistema Cacau-Cabruca, ETC - Escoamento pelo Tronco Sistema Cacau-Cabruca, RC - Riacho Sistema Cacau-Cabruca.

A água da chuva e a vegetação são capazes de influenciar as concentraçóes dos nutrientes à medida que atingem os diferentes compartimentos (P, PI e ET). Inicialmente, ocorre lavagem da atmosfera através da chuva, posteriormente a chuva escoa pelo dossel e, consequentemente, podem ocorrer dois processos: a

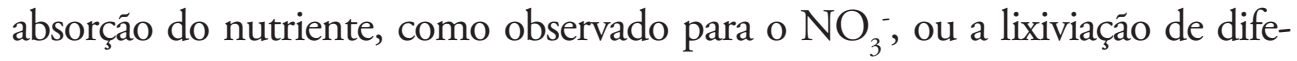
rentes partes da vegetação, promovendo acréscimo das concentrações (como é o caso do $\mathrm{NH}_{4}^{+}$e do NOD). Isso demonstra a importância da vegetação na entrada de nutrientes nos ecossistemas florestais até alcançar o solo (LOPES, 2001; TOBÓN; SEVINK; VERSTRATEN, 2004; PROTIL; MARQUES; PROTIL, 2009). O enriquecimento das diferentes formas de Nitrogênio iniciase a partir de processos que ocorrem na atmosfera; no entanto, alguns estudos sugerem que a maior contribuição se dá nos estratos do dossel que contribuem para o enriquecimento na PI (LEITE et al., 2011; HOFHANSL et al., 2011).

$\mathrm{Na}$ área de floresta, o ET foi a via de maior enriquecimento das formas de Nitrogênio, enquanto no sistema cacau-cabruca a principal via foi a PI ( $\mathrm{p}<0,05)$. Hofhansl et al. (2012) observaram importante influência hidroquímica no ET para todos os compostos de nitrogênio, incluindo $\mathrm{NOD}$ e $\mathrm{NH}_{4}^{+}$com consequente enriquecimento do ET. 
$\mathrm{O} \mathrm{NOD}$ e o $\mathrm{NH}_{4}^{+}$apresentaram aumento na sua concentração no sentido Precipitação - Riacho em ambas as microbacias (Tabela 1 e Figura 4). Inversamente, $\mathrm{o} \mathrm{NO}_{3}^{-}$aumentou no sentido Precipitaçáo - Escoamento pelo Tronco e reduziu sua concentração nos rios. Essa redução pode estar relacionada à absorção líquida do $\mathrm{NO}_{3}$ - por epífitas, briófitas, liquens e microrganismos (JORDAN; GOLLEY; HALL, 1980; FORTI; MOREIRA-NORDEMANN, 1991; GERMER et al., 2007), à absorção pela vegetação ou à perda pelo processo de denitrificação (PARKER, 1983; TOBÓN; SEVINK; VERSTRATEN, 2004).

TABELA 1 - Concentraçôes de Nitrogênio nas vias hidrológicas e nos riachos de áreas de floresta e sistema cacau-cabruca, Sul da Bahia

\begin{tabular}{|c|c|c|c|c|c|c|}
\hline \multicolumn{5}{|c|}{ Floresta } & \multicolumn{2}{|c|}{ SAF Cacau-Cabruca } \\
\hline & $\mathrm{NO}_{3}^{-}$ & $\mathrm{NH}_{4}^{+}$ & NOD & $\mathrm{NO}_{3}^{-}$ & $\mathrm{NH}_{4}^{+}$ & NOD \\
\hline Precipitação & $\begin{array}{c}3,6 \pm 3,9 \\
\text { (n.d. }-12,8)\end{array}$ & $\begin{array}{c}0,8 \pm 0,6 \\
\text { (n.d. }-3,4 \text { ) }\end{array}$ & $\begin{array}{c}6,3 \pm 5,6 \\
\text { (n.d. }-30,1)\end{array}$ & $\begin{array}{c}1,4 \pm 2,3 \\
\text { (n.d. }-9,2)\end{array}$ & $\begin{array}{c}0,7 \pm 0,6 \\
\text { (n.d. }-2,8)\end{array}$ & $\begin{array}{c}8,4 \pm 6,4 \\
\text { (n.d. }-103,5)\end{array}$ \\
\hline $\begin{array}{l}\text { Precipitação } \\
\text { Interna }\end{array}$ & $\begin{array}{c}0,5 \pm 0,7 \\
\text { (n.d. }-40,9)\end{array}$ & $\begin{array}{c}0,6 \pm 0,6 \\
\text { (n.d. }-9,1 \text { ) }\end{array}$ & $\begin{array}{c}4,7 \pm 4,6 \\
\text { (n.d. }-81,7 \text { ) }\end{array}$ & $\begin{array}{c}1,9 \pm 2,3 \\
\text { (n.d. }-125,3 \text { ) }\end{array}$ & $\begin{array}{c}2,7 \pm 4,3 \\
\text { (n.d. }-31,7 \text { ) }\end{array}$ & $\begin{array}{c}15,6 \pm 27,3 \\
\text { (n.d. }-40,6)\end{array}$ \\
\hline $\begin{array}{l}\text { Escoam. } \\
\text { pelo tronco }\end{array}$ & $\begin{array}{c}6,8 \pm 9,7 \\
\text { (n.d.- } 42,3 \text { ) }\end{array}$ & $\begin{array}{c}1,5 \pm 1,8 \\
\text { (n.d. }-11,3 \text { ) }\end{array}$ & $\begin{array}{c}6,7 \pm 14,1 \\
\text { (n.d. }-61,9)\end{array}$ & $\begin{array}{c}0,5 \pm 0,5 \\
\text { (n.d. }-5,2)\end{array}$ & $\begin{array}{c}1,9 \pm 3,2 \\
\text { (n.d. }-44,2)\end{array}$ & $\begin{array}{c}5,9 \pm 5,8 \\
\text { (n.d. }-87,1)\end{array}$ \\
\hline Riacho & $\begin{array}{c}2,2 \pm 3,4 \\
\text { (n.d. }-10,9)\end{array}$ & $\begin{array}{c}3,3 \pm 4,4 \\
(0,7-5,6)\end{array}$ & $\begin{array}{c}12,3 \pm 8,4 \\
(1,9-24,5)\end{array}$ & $\begin{array}{c}0,8 \pm 0,8 \\
\text { (n.d. }-1,9 \text { ) }\end{array}$ & $\begin{array}{c}2,8 \pm 1,6 \\
(1,3-6,0)\end{array}$ & $\begin{array}{c}34,2 \pm 22,1 \\
(11,2-85,9)\end{array}$ \\
\hline
\end{tabular}

Fonte: Dados da pesquisa.

A redução da concentração de nutrientes, ao fluir pelos compartimentos florestais, como é o caso do $\mathrm{NO}_{3}$, pode estar associada a fenômenos como absorção e/ou volatilização dos nutrientes investigados. Esse resultado também foi constatado em outros estudos em diferentes tipos florestais (JORDAN; GOLLEY; HALL, 1980; PARKER, 1983; TOBÓN; SEVINK; VERSTRATEN, 2004). Tobón, Sevink e Verstraten (2004) argumentam que, mesmo ocorrendo variabilidade espacial entre florestas, as estimativas da deposição de Nitrogênio demonstram que grande parte desse nutriente é absorvida na copa das árvores, e observam ainda que as baixas concentraçóes de nutrientes sugerem a ocorrência de uma menor lixiviação ou absorção líquida pelo dossel, ressaltando que o decréscimo da concentração é mais frequente na PI do que no ET. 


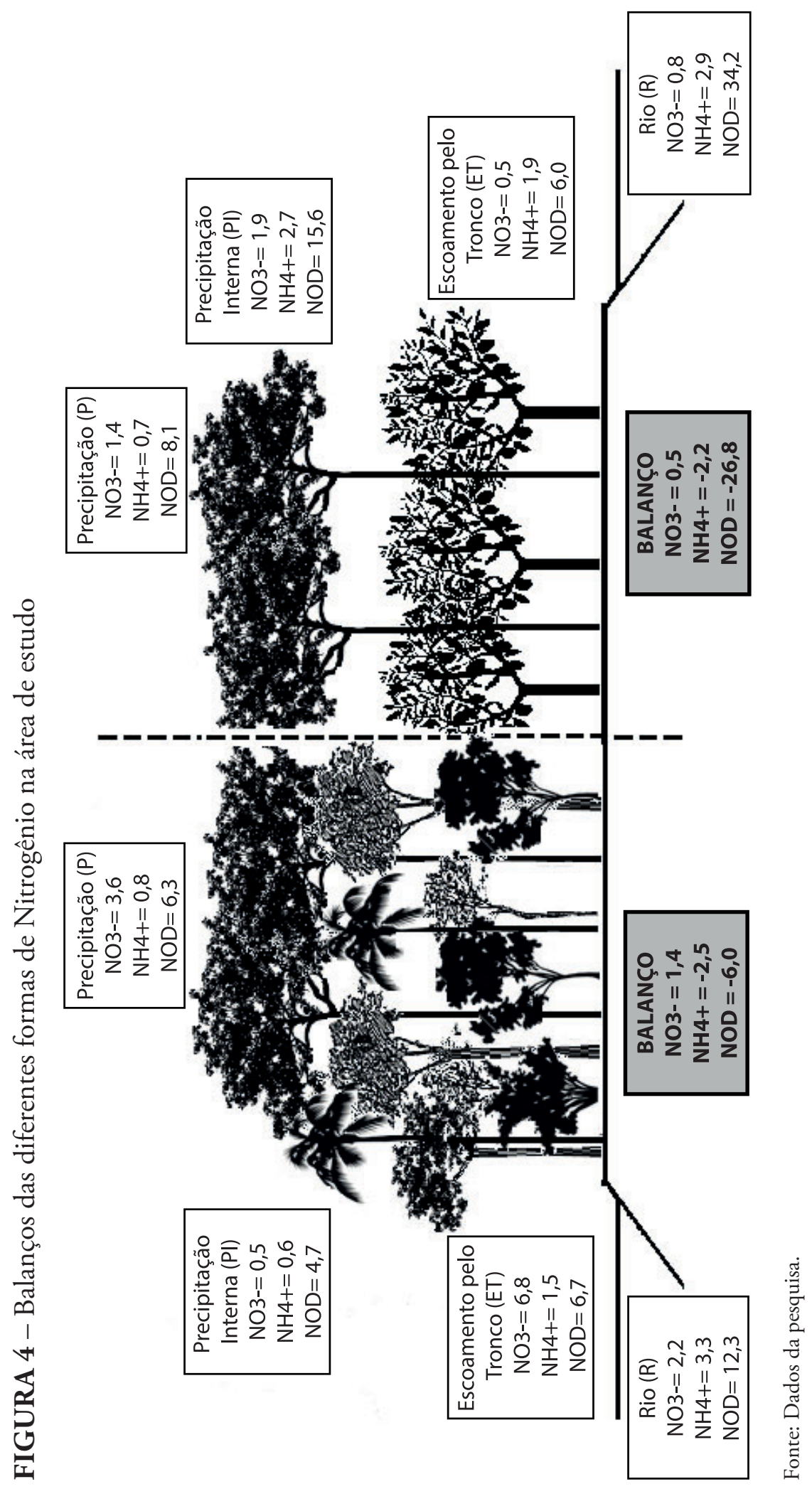


O ET, apesar de representar a via de menor contribuição de água neste estudo, não ultrapassando $0,5 \%$ do total do volume precipitado, não pode ser desprezado, tendo em vista que a água escoada pelo tronco teve sua velocidade reduzida, diminuindo o impacto da água ao atingir o solo e facilitando o processo de infiltração. Vários autores destacam a importância e benefícios da pequena parcela do ET para a vegetação e para o solo, especialmente em períodos menos chuvosos (LEVIA JUNIOR et al., 2003; GERMER; WERTHER; ELSENBEER, 2010; HOFHANSL et al., 2012). Essa via também contribui para a manutenção da água no solo, reduzindo o escoamento superficial e viabilizando o abastecimento do lençol freático. Estudos em florestas tropicais demonstram que os nutrientes no ET são dez vezes superiores, quando comparados aos valores de P e PI (HOFHANSL et al., 2012). No presente estudo, um aumento de $\mathrm{NO}_{3}{ }_{3}^{-}$no ET pode ser observado principalmente na área de floresta $(0,5$ a $6,8 \mu \mathrm{M})$ (Figura 3). No caso do sistema cacau-cabruca, houve uma redução no sentido PI-ET $(1,9$ a $0,5 \mu \mathrm{M})$. Estudos em florestas tropicais na Costa Rica revelaram que há uma diminuição de Nitrogênio e Fósforo no ET nas diferentes tipologias florestais estudadas. Esta redução foi associada às rápidas trocas e incorporaçóes que ocorrem ao longo do tronco e pela presença de epífitas (HOFHANSL et al., 2012).

Em bacias hidrográficas não impactadas tem sido demonstrado que a vegetação contribui significativamente para a remoção do Nitrato nos ecossistemas, registrando diminuiçáo das concentrações de Nitrato no solo com o aumento da profundidade (SALEMI et al., 2013, 2015; SUDDUTH; PERAKIS; BERNHARDT, 2013). Souza (2014), em estudos sobre Nitrogênio na solução do solo nas mesmas áreas do presente estudo, demonstrou que as maiores concentrações das diferentes formas de $\mathrm{N}$ estão nos primeiros $15 \mathrm{~cm}$ de solo, podendo atingir $90 \mathrm{~cm}$, porém em quantidade reduzida. Este padrão pode estar relacionado com o fato de que alguns nutrientes se esgotam ao longo do tempo, e nos sistemas agroflorestais cacau-cabruca, que são antigos, a serapilheira pode não ser suficiente para suprir essa perda nas zonas mais profundas (DAWOE; ISAAC; QUASHIE, 2010; SELLE, 2007; VITOUSEK, 1982).

Estudos desenvolvidos em sistemas de cacau com sombreamento de eritrina, também no Sul da Bahia, demonstraram o mesmo padrão, sendo observada retenção de Nitrogênio no folhedo e no solo com baixa lixiviação para os sistemas aquáticos (GAMA-RODRIGUES; MIRANDA, 1991). 
Alguns processos podem contribuir para a retenção de Nitrogênio, tais como acúmulo de Nitrogênio no solo, incorporação pelas plantas e denitrificação. Além disso, as zonas ripárias representam sumidouros para determinados nutrientes, tais como Nitrogênio e Fósforo e, eventualmente, fonte de nutrientes quando se tornam saturadas. No presente estudo, provavelmente parte do $\mathrm{NO}_{3}$ - escoado pelo tronco e produzido no sistema terrestre através dos processos de mineralização e nitrificação pode ser retida na zona ripária e não ser lixiviada para o sistema aquático.

Em relação ao $\mathrm{NH}_{4}^{+}$e ao $\mathrm{NOD}$, observou-se um aumento a partir do contato da precipitação com a vegetação nas duas microbacias (Tabela 1). $\mathrm{O}$ aumento dos nutrientes ( $\mathrm{NH}_{4}^{+}$e NOD) após a passagem pelo dossel e consequente aumento no rio pode ser explicado pela dissolução na água da chuva de compostos depositados através da lixiviação das copas das árvores (PARKER, 1983; LEITE et al., 2011; JOST et al., 2011; HOFHANSL et al., 2012).

Os excrementos animais também podem influenciar nas concentraçooes de N nos diferentes compartimentos. Tobón, Sevink e Verstraten (2004) observaram na floresta amazônica que muitas espécies de árvores apresentaram um aumento na concentração de nutrientes no período de floração e frutificação. Nesse período, a atividade de diversos organismos no dossel aumenta consideravelmente, resultando na liberaçáo de solutos nos diferentes compartimentos, oriundos dos excrementos desses organismos.

Apesar de apresentar um balanço negativo em ambas as bacias (Figura 3), $\mathrm{o} \mathrm{NH}_{4}^{+}$foi similar ao $\mathrm{NO}_{3}{ }_{3}^{-}$no rio da área de floresta e foi predominante no rio do sistema cacau-cabruca $(\mathrm{p}<0,05)$, variando de 1,3 a $6,0 \mu \mathrm{M}$. Estudos realizados nessas mesmas áreas por Silva (2012) e Souza (2014) demonstraram que as taxas de mineralização e nitrificação no solo no sistema cacaucabruca apresentam valores inferiores quando comparados à área de floresta. As maiores taxas de mineralização e nitrificação do solo nas áreas de floresta resultam em maiores concentraçóes de $\mathrm{NO}_{3}{ }^{-}$nos primeiros centímetros do solo, podendo ser incorporadas pela vegetação ou lixiviadas para os rios.

Acredita-se que as maiores concentraçóes de $\mathrm{NH}_{4}{ }^{+}$no sistema cacaucabruca são decorrentes das características do rio e seu entorno. Este rio, apesar de possuir uma área de drenagem maior que o rio da área de floresta, apresenta diversos trechos com fluxo lento de água e áreas de remanso. Além disso, a alta concentração de matéria orgânica resultante da serapilheira produzida pelo próprio sistema cacau-cabruca resulta em maior acidez nos sistemas aquáticos. Ainda, o baixo fluxo da água em determinadas épocas do ano, 
associado ao acúmulo de matéria orgânica, resulta em condições de anoxia que podem contribuir para o aumento de processos como denitrificaçáo e redução dissimilatória do nitrato, reduzindo os processos de nitrificação.

O NOD representa a principal forma de $\mathrm{N}$ em todas as vias hidrológicas estudadas, apresentando os maiores balanços negativos $(\mathrm{p}<0,05)$, - 6,0 e - 26,8 para as áreas de floresta e sistema cacau-cabruca, respectivamente. No sistema cacau-cabruca, houve um aumento do NOD no sentido Precipitaçáo - Riacho, apresentando um balanço negativo quase três vezes maior quando comparado à área de floresta $(\mathrm{p}<0,05)$. Este tipo de sistema agroflorestal, pela própria estrutura do cacaueiro, contribui para o aumento da transferência de nutrientes para o solo e, consequentemente, para os rios (SANTANA; CABALA-ROSAND; SERÔDIO, 1990). Estudos desenvolvidos nestes sistemas demonstraram que a serapilheira é a principal responsável pelo aumento da concentração de nutrientes na solução do solo (CURVELO et al., 2009), demonstrando que o mesmo é autossustentável em termos nutricionais.

Além disso, o aumento das formas orgânicas pode estar relacionado à lixiviação das folhas do cacaueiro, uma vez que essas folhas possuem maior área do que as folhas das árvores da floresta, favorecendo uma maior deposição dos compostos nitrogenados. $\mathrm{O}$ Nitrogênio absorvido pelas plantas através da solução do solo, na forma de $\mathrm{NO}_{3}{ }^{-}$ou $\mathrm{NH}_{4}{ }_{4}^{+}$, é principalmente incorporado à biomassa e, posteriormente, retorna ao solo via serapilheira, sendo os nutrientes foliares um meio alternativo de caracterizar a disponibilidade de nutrientes em florestas tropicais (VITOUSEK, 1982). Em diversos sistemas florestais, tem sido observado que a diminuição do índice de área foliar possivelmente reduz a quantidade de deposição seca e úmida no dossel da floresta, contribuindo para uma redução de íons na PI e ET (TOBÓN; SEVINK; VERSTRATEN, 2004). O índice de área foliar pode influenciar no aumento da retenção de partículas atmosféricas e estas, posteriormente, podem ser carreadas pela $\mathrm{P}$, favorecendo o enriquecimento da PI (PROTIL; MARQUES; PROTIL, 2009).

Os resultados encontrados estáo de acordo com a maioria dos estudos de nutrientes em vias hidrológicas (MICHOPOULOS; BALOUTSOS; ECONOMOU, 2008; OZIEGBE; MUOGHAL; OKE, 2011). Há um predomínio das formas orgânicas nas diferentes vias hidrológicas em áreas de Mata Atlântica (SP) e na Amazônia (RO) (CHAVES et al., 2009; SALEMI et al., 2013). 
Outros fatores que podem alterar as perdas de Nitrogênio para os ecossistemas aquáticos incluem a quantidade de chuva, o aproveitamento da água pela vegetação e o conteúdo de $\mathrm{N}$ no solo. De maneira geral, na microbacia de floresta, as concentrações das diferentes formas de Nitrogênio aumentaram à medida que atravessaram o dossel. No sistema cacaucabruca, este padrão foi observado principalmente para o NOD.

\section{Conclusão}

Embora o sistema agroflorestal cacau-cabruca implique na remoção da vegetação do sub-bosque para o plantio do cacaueiro, não foram encontradas diferenças nos balanços das formas inorgânicas de Nitrogênio entre as duas microbacias estudadas. Foram observadas diferenças apenas para o NOD, que além de apresentar um incremento ao longo do dossel, apresentou as maiores saídas através dos rios, principalmente na microbacia do sistema agroflorestal cacau-cabruca. 


\section{Referências}

ANDRADE, T. M. B. et al. Dynamics of dissolved forms of carbon and inorganic $\mathrm{N}$ in small watersheds of the Coastal Atlantic Forest in Southeast Brazil. Water Air and Soil Pollution, v. 214, n.1, p. 393-408, 2011.

ARGÔLO, L. M. H. Avaliação de genótipos de Heliconia spp. sob cultivo a pleno sol e cabruca. 2009. 76 f. Dissertação (Mestrado em Produção Vegetal) - Universidade Estadual de Santa Cruz, Ilhéus, BA, 2009.

ASMAR, S. R. E.; ANDRADE, M. P. Geografia da microrregiáo cacaueira, Itabuna, BA. Ilhéus, BA: Comissão Executiva do Plano da Lavoura Cacaueira, 1977.

BRASIL. MINISTÉRIO DE DESENVOLVIMENTO AGRÁRIO MDA. Manual Agroflorestal para Mata Atlântica. 2008. Disponível em: <http://www.centroecologico.org.br/revista>. Acesso em: 9 mar. 2015.

CURVELO, K. et al Aporte de Nutrientes na Serapilheira e na Água do Solo em Cacau Cabruca Floresta Secundária e Pastagem. Agrotrópica, Itabuna, Bahia. v. 21, n.1, p. 55-64. 2009.

CATRIONA, M. O. et al. Rainfall partitioning into throughfall and stemflow and associated nutrient fluxes: land use impacts in a lower montane tropical region of Panama. Biogeochemistry, Department of Ecology and Evolutionary Biology The University of Kansas Lawrence, Kansas, USA. v. 111, n.1-3, p. 661-676, 2012.

CHAVES, J. et al. Nitrogen transformations in flow paths leading from soils to streams in Amazon Forest and pasture. Ecosystems, v. 12, n. 6, p. 961-972, 2009.

DAWOE, E. K.; ISAAC, M. E.; QUASHIE, A. S. J. Litterfall and litternutrient dynamics under cocoa ecosystems in lowland humid Ghana. Plant and Soil, v. 330, n. 1, p. 55-64. 2010.

DEEGAN, L. A. et al. Amazon deforestation alters small stream structure, nitrogen biogeochemistry and connectivity to larger rivers. Biogeochemistry, Department of Ecology and Evolutionary Biology The University of Kansas Lawrence, Kansas, USA. v. 105, n. 1, p. 53-74, 2011. 
FERNANDES, C. A. S. Avaliaçáo da qualidade do solo em áreas de cacau cabruca, mata e policultivo no sul da Bahia. 2008. 85 f. Dissertação (Mestrado em Produção Vegetal) - Universidade Estadual de Santa Cruz, Ilhéus, BA, 2008.

FISHER, S. S. G.; SPONSELER, R. A.; HEFFERNAN, J. B. Horizons in stream biogeochemistry: flowpaths to progress. Ecology, v. 85, n.9, p. 2369-2379, 2004.

FORTI, M. C.; MOREIRA-NORDEMANN, L. M. Rainwater and throughfall chemistry in a Terra Firme Rain-Forest - Central Amazonia. Journal of Geophysical Research - Atmospheres, v. 96,n. D4, p. 74157421, 1991.

\section{FUNDAÇÃO SOS MATA ATLÂNTICA. Atlas dos remanescentes}

florestais da mata atlântica: período de 2011-2012. Relatório Final. São Paulo: Fundaçáo SOS Mata Atlântica/Instituto Nacional de Pesquisas Espaciais, 2013. Disponível em: https://www.sosma.org.br/tag/atlas-dos-remanescentes-florestais-da-mata-atlantica/ >. Acesso em: 11 abr. 2015.

GALINDO-LEAL, C.; CAMARA, I. G. Mata Atlântica: ameaças e perspectivas. Belo Horizonte: Conservation International, 2005.

GAMA-RODRIGUES, A. C.; MIRANDA, R. C. C. Efeito da chuva na liberaçáo de nutrientes do folhedo num agrossistema de cacau do sul da Bahia. Pesquisa Agropecuária Brasileira, Brasília, DF, v. 26, n. 9, p. 1345-1350, 1991.

GERMER, S.; WERTHER, L.; ELSENBEER, H. Have we underestimated stemflow? Lessons from an open tropical rainforest. Journal of Hydrology, v. 395, n. 3-4, p. 169-179, 2010.

GERMER, S. et al. Seasonal and within-event dynamics of rainfall and throughfall chemistry in an open tropical rainforest in Rondônia, Brazil. Biogeochemistry, Department of Ecology and Evolutionary Biology The University of Kansas Lawrence, Kansas, USA. v. 86, n. 2, p. 155-174, 2007.

GRASSHOFF, K.; ERHARDT, M.; KREMLING, K. Methods of seawater analysis. Weinheim: Verlag Chemie, 1983. 
HOFHANSL, F. W. et al. Topography strongly affects atmospheric deposition and canopy exchange processes in different types of wet lowland rainforest, Southwest Costa Rica. Biogeochemistry, Department of Ecology and Evolutionary Biology The University of Kansas Lawrence, Kansas, USA. v. 106, n. 3, p. 371-396, 2011.

HOFHANSL, F. et al. Controls of hydrochemical fluxes via stemflow in tropical lowland rainforests: Effects of meteorology and vegetation characteristics. Journal of Hydrology, local, v. 452-453, p. 247-258, 2012.

HARTSHORN, G. S. Plantas. In: JANZEN, D. H. (Ed.). Historia natural de Costa Rica. San José, Costa Rica: Editorial de La Universidad de Costa Rica, cap. 7, p. 119-353. 1991.

INSTITUTO BRASILEIRO DE GEOGRAFIA E ESTATÍSTICA IBGE. Levantamento de recursos naturais. Rio de Janeiro: IBGE, 1992.

JARDIM, J. G. Uma caracterização parcial da vegetação da regiáo sul da Bahia, Brasil. In: PRADO, P. I.; LANDAU, E. C.; MOURA, R. T.; PINTO, L. P. S.; FONSECA, G. A. B.; ALGER, K. (Eds.). Corredor de biodiversidade da Mata Atlântica do sul da Bahia. Ilhéus-BA: IESB/ CI/CABS/UFMG/UNICAMP, 2003. 1 CD-ROM.

JICKELLS T. et al.. The cycling of organic nitrogen through the atmosphere. Philosophical Transactions B, Londres. v. 368, n. 1621, 2013. Disponível em: <http://rstb.royalsocietypublishing.org/content/368/1621/20130115>. Acesso em: 11 abr. 2015.

JORDAN, C.; GOLLEY, F.; HALL, J. Nutrient scavenging of rainfall by canopy of an Amazonian. Biotropica, University of Georgia, Georgia, USA. v. 12, n. 1, p. 61-66, 1980.

JOST, G. et al. Nitrogen leaching of two forest ecosystems in a karst watershed. Water Air Soil Pollution, v. 218, n.1-4, p. 633-649, 2011.

LANDAU, E. C. Normais de precipitação no sudeste da Bahia, Brasil. In: PRADO, P. I.; LANDAU, E. C.; MOURA, R. T.; PINTO, L. P. S.; FONSECA, G. A. B.; ALGER, K. (Eds.). Corredor de biodiversidade da mata atlântica do sul da Bahia. Ilhéus, BA: IESB/CI/CABS/UFMG/ UNICAMP, 2003. 1 CD-ROM. 
LEITE, N. K. et al. Intra and interannual variability in the Madeira River water chemistry and sediment load. Biogeochemistry, Department of Ecology and Evolutionary Biology The University of Kansas Lawrence, Kansas, USA. v. 105, n.1-3, p. 37-51, 2011.

LEVIA JUNIOR, D. F.; FROST, E. E. A Review and evaluation of stemflow literature in the hydrologic and biogeochemical cycles of forested and agricultural ecosystems. Journal of Hydrology, local, v. 274, n.1-4, p. 1-29, 2003.

LOBÃO, D. E. et al. Cacau-Cabruca: um modelo sustentável de agricultura tropical. Indícios Veementes, São Paulo, v. 3, p. 10-24, 1997.

LOBÃO, D. E.; SETENTA, W. C.; VALLE, R. R. Sistema agrossilvicultural cacaueiro - modelo de agricultura sustentável. Agrossilvicultura, v. 1, n. 2, p. 163-173, 2004.

LOBÃO, D. E. et al. Cacau-Cabruca - sistema agrossilvicultural tropical. In: VALLE, R. R. (Ed.). Ciência, tecnologia e manejo do cacaueiro. Itabuna, BA: Gráfica e Editora Vital, 2007. p. 290-323.

LOBÃO, D. E.; VALERI. S. V. Sistema cacau-cabruca: conservação de espécies arbóreas da floresta atântica. Agrotrópica, Itabuna, BA, v. 21, n. 1, p. 43-54, 2009.

LOPES, M. I. M. S. Fluxo de água, balanço químico e alteraçóes no solo da Floresta Atlântica atingida pela poluiçáo aérea de Cubatáo, SP, Brasil. 2001. 217 f. Tese (Doutorado em Ecologia), Centro de Energia Nuclear na Agricultura, Universidade de São Paulo, Piracicaba, SP, 2001.

MARTINI, A. M. Z. A hot-point within a hotspot: a high diversity site in Brazil's Atlantic Forest. Biodiversity Conservation, v. 16, n. 11, p. 3111-3188, 2007.

McCUNE, D. C.; BOYCE, R. L. Precipitation and the transfer of water, nutrients and pollutants in the tree canopies. Trends in Ecology \& Evolutions, v. 7, n. 1, p. 4-7, 1992.

MICHOPOULOS, P.; BALOUTSOS, G.; ECONOMOU, A. Nitrogen cycling in a Mature Mountainous Beech Forest. Silva Fennica, local, v. 42, p. 5-17, 2008. 
NEILL, C. et al. Deforestationfor pasture alters Nitrogen and phosphorus in small Amazonian streams. Ecological Applications, v. 11, n. 6, p. 1817-1828, 2001.

NEILL, C.et al. Runoff sources and land cover change in the Amazon: and end-member mixing analysis from small watersheds. Biogeochemistry, Department of Ecology and Evolutionary Biology The University of Kansas Lawrence, Kansas, USA.v. 105, n. 7. p. 7-18, 2011.

OZIEGBE, M. B.; MUOGHAL, J. I.; OKE, S. O. Litterfall, precipitation and nutrient fluxes in a secondary lowland rain forest in Ile-Ife, $\mathrm{Ni}$ geria. Acta Botanica Brasilica, local, v. 25, n. 3, p. 664-671, 2011.

PARKER, G. G. Throughfall and stemflow in the forest nutrient cycle. Advances in Ecological Research, v. 13, p. 57-133, 1983.

PARRON, L. M.; BUSTAMANTE, M. M. C.; MARKEWITZ, D. Fluxes of nitrogen and phosphorus in a gallery forest in the Cerrado of central Brazil. Biogeochemistry, Department of Ecology and Evolutionary Biology The University of Kansas Lawrence, Kansas, USA. v. 105, n. 1-3, p. 89-104, 2011.

PROTIL, C. Z.; MARQUES, R.; PROTIL, R. M. Variação sazonal e redistribuição de bioelementos de quatro espécies arbóreas em três tipologias florestais da Floresta Atlântica do Paraná. Floresta, Curitiba, Paraná. v. 39, n. 3, p. 699-717, 2009.

RODÁ, F.; AVILA, A.; BONILLA, D. Precipitation, throughfall, soil solution and streamwater chemistry in a holm-oak (Quercus ilex) forest. Journal of Hydrology, v. 116, n. 1-4. p. 167-183, 1990.

SÁ, D. F. Fatores edafo-climáticos seletivos ao zoneamento da cacauicultura no sudeste da Bahia. Revista Theobroma, Itabuna, Bahia. v. 12, n. 3. p. 169-187, 1982.

SALEMI, L. F. et al.. Land-use change in the Atlantic rainforest region: Consequences for the hydrology of small catchments. Journal of Hydrology, v. 499, p. 100-109, 2013.

SALEMI, L. F. et al. Nitrogen Dynamics in Hydrological Flow Paths of a Small Tropical Pasture Catchment. Catena, v. 127, p. 250-257, 2015. 
SAMBUICHI, R. H. R. Fitossociologia e diversidade de espécies arbóreas em cabruca (Mata Atlântica raleada sobre plantação de cacau) na região sul da Bahia, Brasil. Acta Botanica Brasilica, São Paulo-SP. v. 16, n. 1, p. 89-101, 2002.

SAMBUICHI, R. H. R. Ecologia da vegetaçáo arbórea de cabruca Mata Atlântica raleada utilizada para cultivo de cacau na regiáo sul da Bahia. 2003. 140 f. Tese (Doutorado em Ecologia) - Universidade de Brasília, Brasília, DF, 2003.

SAMBUICHI, R. H. R. Estrutura e dinâmica do componente arbóreo em área de cabruca na região cacaueira do sul da Bahia, Brasil. Acta Botanica Brasilica, São Paulo-SP.v. 20, n. 4, p. 943-954, 2006.

SANTANA, M. B.; CABALA-ROSAND, P.; SERÔDIO, M. H. Reciclagem de nutrientes em agrossistemas de cacau. Agrotrópica, Itabuna-BA. v. 2, n. 2, p. 68-74, 1990.

SELLE, G. L. Nutrient cycling in forest ecosystems. Review Article. Bioscience Journal, Uberlandia-MG. v. 23, n. 4, p. 29-39, 2007.

SILVA, L. P. Dinâmica de nitrogênio em microbacias em remanescentes de Mata Atlântica (Itacaré - Uruçuca, BA). 2012. 58 f. Dissertação (Mestrado em Sistemas Aquáticos Tropicais) - Universidade Estadual de Santa Cruz, Ilhéus, BA, 2012.

SOUZA, J. C. Influência do sistema agroflorestal cacau-cabruca na dinâmica de nitrogênio na soluçáo do solo em microbacias na regiáo sul da Bahia. 2014. 28 f. Dissertação (Mestrado em Sistemas Aquáticos Tropicais) - Universidade Estadual de Santa Cruz, Ilhéus, BA, 2014.

SUDDUTH, E. B.; PERAKIS, S. S.; BERNHARDT, E. S. Nitrate in watersheds: Straight from soils to streams? Journal of Geophysical Research: Biogeosciences, v. 118, n. 1, p. 1-12, 2013.

TOBÓN, C.; SEVINK, J.; VERSTRATEN, J. M. Solute fluxes in throughfall and stemflow in four forest ecosystems in northwest Amazonia.

Biogeochemistry, Department of Ecology and Evolutionary Biology The University of Kansas Lawrence, Kansas, USA. v. 70, n.1, p. 1-25, 2004. 
VELTHORST, E. J.; BREEMEN, N. Changes in the composition of rainwater upon passage through the canopies of trees and of ground vegetation in a Dutch oak birch forest. Plant and Soil, v. 119, n.1. p. 81-85, 1989.

VITOUSEK, P. M. Nutrient cycling and use efficiency. The American Naturalist, v. 119, n. 4, p. 553-572, 1982. 


\title{
Limnologia de rios intermitentes: a bacia hidrográfica do rio Jequiezinho como estudo de caso
}

\author{
Poliana Simas Magalhães \\ Nadson Ressyé Simões \\ Sérgio Luiz Sonoda
}

\section{Introdução}

De toda a superfície terrestre, $40 \%$ correspondem às zonas áridas, sendo que estas vêm aumentando em função de distintos processos, tais como desertificação, variação climática e desmatamento. Larned et al. (2010) ressaltam que, devido às mudanças climáticas, o número e a extensão de rios temporários podem aumentar em regióes que enfrentam uma tendência à seca e em regiôes onde há a captação de água para o uso socioeconômico.

Aproximadamente 10\% do território brasileiro está classificado como região semiárida, onde cerca de 23,5 milhóes de pessoas estão distribuídas (BARBOSA et al., 2012). Assim, os rios intermitentes são ecossistemas fundamentais para as estratégias de sobrevivência da população humana local (MALTCHIK, 1996). Conforme definição da Superintendência do Desenvolvimento do Nordeste (SUDENE), esta região também é conhecida como Polígono das Secas, que é formado por municípios, principalmente da região Nordeste, nos quais o volume de chuva anual é menor do que $800 \mathrm{~mm}$. Recentemente, o Ministério da Integraçăo Nacional acrescentou 102 novos municípios aos 1.031 municípios incorporados nos limites até então vigentes, e a área classificada oficialmente como semiárida aumentou de $892.309,4 \mathrm{~km}^{2}$ para 969.589,4 $\mathrm{km}^{2}$ (CIRILO, 2008). O semiárido baiano tem peso marcante na constituição desse total, sendo que seus $373.000 \mathrm{~km}^{2}$ contribuem com mais de um terço dessa área e corres- 
pondem a $66 \%$ do território do estado da Bahia. Nesta região, vivem mais de seis milhóes de pessoas e sua densidade demográfica corresponde a 16 $\mathrm{hab} / \mathrm{km}^{2}$ (MENESES, 1996).

Existem hoje diversas razóes para o estudo dos rios, especialmente os de regióes áridas e semiáridas. $\mathrm{O}$ reconhecimento da relação entre os ecossistemas aquáticos temporários e os processos de perturbaçóes hídricas (cheia e seca), por exemplo, permitiria predizer e acompanhar as respostas do ambiente às alteraçóes climáticas atualmente em processo no planeta (MALTCHIK, 1996).

A regiáo semiárida brasileira é pobre em termos de volume de escoamento de água dos rios devido à variabilidade temporal das precipitaçóes e das características geológicas dominantes Nessa regiáo, predominam os solos rasos sobre rochas cristalinas e, consequentemente, ocorrem baixas trocas de água entre o rio e o solo adjacente, resultando em uma extensa e densa rede de rios temporários, sendo o rio Sáo Francisco uma exceção (CIRILO, 2008).

Do ponto de vista hidrogeológico, a característica peculiar dessas regióes mais secas é seu escasso valor de recarga natural. Como consequência desse déficit climático, os processos de descarga nestas regióes são praticamente nulos, produzindo-se nos leitos dos rios, geralmente, sistemas temporários ou efêmeros (MALTCHIK, 1996). Segundo Williams (1987), lagos e riachos temporários estáo presentes em várias partes do mundo e são definidos como corpos de água natural que apresentam uma fase seca de duração variável.

Os rios temporários estão sempre associados a áreas de baixa precipitação e alta evaporação e, em geral, apresentam duas fases de perturbações hidrológicas extremas: cheia e seca. Essas fases têm papel importante no funcionamento de ecossistemas hídricos, especialmente em regióes áridas e semiáridas. Embora a maioria dos estudos sobre perturbaçóes hidrológicas em rios temporários enfoque a influência da cheia no funcionamento desses ecossistemas, a seca também os perturba, em alguns casos, com efeitos negativos maiores, tais como a diminuição da biodiversidade e a simplificação dos ambientes (LAKE, 2003).

Apesar de serem intermitentes, os corpos de água temporários podem sustentar uma alta produtividade e biodiversidade, não só com relação à fauna e à flora aquáticas, mas também devido à concentração de outros animais e vegetais em suas proximidades (SHIEL; GREEN; NIEL- 
SEN, 1998). Nestes ambientes, os organismos necessitam de estratégias que permitam a sua sobrevivência, desde adaptaçóes relacionadas com as tolerâncias fisiológicas, até modificações na história de vida e mecanismos de dispersão (WILLIAMS, 1997; HUMPHRIES; BALDWIN, 2003). Os microcrustáceos apresentam um importante papel no metabolismo de ecossistemas aquáticos devido à sua posiçáo intermediária na cadeia trófica, funcionando como elo entre produtores primários e consumidores secundários. Além disso, nos ambientes aquáticos temporários, eles são altamente diversificados, devido à sua plasticidade adaptativa para resistir a flutuaçôes ambientais estressantes (WILLIAMS, 1997).

Diante da importância ecológica e social dos rios temporários, foi desenvolvido um projeto de pesquisa na bacia do rio Jequiezinho (Bahia) durante os anos de 2002 e 2003, com o objetivo de caracterizar, do ponto de vista limnológico, trechos de rios temporários que a compóem, bem como analisar a estrutura de uma comunidade de microcrustáceos planctônicos que habita estes ambientes. Os resultados apresentados neste capítulo foram obtidos durante a realização desse projeto, e as metodologias de coleta e de análise foram descritas em Simóes, Sonoda e Ribeiro (2008, 2011).

\section{Caracterizaçáo da bacia do rio Jequiezinho}

O semiárido baiano apresenta muitas áreas úmidas temporárias. Esta característica está diretamente relacionada com a precipitação dessa região, onde rios e riachos são irregulares e estão em áreas de solos rasos e pouco permeáveis, o que dificulta o armazenamento de água. A vegetação predominante é a caatinga, que não proporciona uma proteção para o solo, aumentando consideravelmente a perda de água; a geomorfologia caracteriza-se pela presença de grandes avenidas e ausência de meandros (IBGE, 1999). Parte da bacia do rio de Contas (Figura 1) enquadra-se nesse contexto. Ela está limitada pelos paralelos $12^{\circ} 55^{\prime}$ e $15^{\circ} 10^{\prime} \mathrm{S}$ e pelos meridianos $38^{\circ} 57^{\prime}$ e $42^{\circ} 00^{\prime}$ WGr, apresentando como bacias vizinhas as dos rios Paraguaçu e Jiquiriçá (bacia do Recôncavo) ao norte; as bacias dos rios Pardo e Cachoeira (bacia do Leste) ao sul; o Oceano Atlântico a leste; e, a oeste, a bacia do São Francisco (IBGE, 1999).

O rio Jequiezinho é um tributário da margem esquerda do rio de Contas e junto com o riacho Conceição e o rio Pati formam a sub-bacia do 
rio Jequiezinho. Este rio nasce no município de Maracás, passa por Lafaiete Coutinho e desemboca no trecho médio do rio de Contas, no município de Jequié (Bahia), e recebe contribuição de dois principais afluentes: o riacho Conceição, que nasce próximo à cidade de Lajedo do Tabocal, e o rio Pati, que tem sua nascente nas imediaçóes do município de Itiruçu, sendo todos de caráter intermitente. No total, são 106 rios e riachos compondo essa unidade hidrográfica.

A Bacia Hidrográfica do Rio Jequiezinho (BHRJ) está situada no sudoeste da Bahia entre as coordenadas $13^{\circ} 40^{\prime}$ e $13^{\circ} 50^{\prime} \mathrm{S}$ e $40^{\circ} 17^{\prime}$ e $40^{\circ} 06^{\prime}$ WGr. A sua área de drenagem é de $1.339 \mathrm{~km}^{2}$ e apresenta um perímetro de 211,61 km (Tabela 1), abrangendo os municípios de Maracás, Lajedo do Tabocal, Itiruçu, Lafaiete Coutinho e Jequié. A Figura 1 apresenta os limites da BHRJ e sua rede de drenagem, bem como a localização dos seis pontos de coletas.

TABELA 1 - Características morfométricas da Bacia Hidrográfica do Rio Jequiezinho

\begin{tabular}{lr}
\hline área da bacia & $1.339,00 \mathrm{~km}^{2}$ \\
perímetro da bacia & $211,61 \mathrm{~km}$ \\
rio Jequiezinho (ext.) & $58,30 \mathrm{~km}$ \\
rio Pati (ext.) & $20,72 \mathrm{~km}$ \\
riacho Conceição (ext.) & $47,71 \mathrm{~km}$ \\
n. ${ }^{\circ}$ de canais & 106 \\
\hline
\end{tabular}

Fonte: Dados da pesquisa. 
FIGURA 1 - A Bacia Hidrográfica do Rio Jequiezinho e a distribuição dos pontos de coletas amostrados

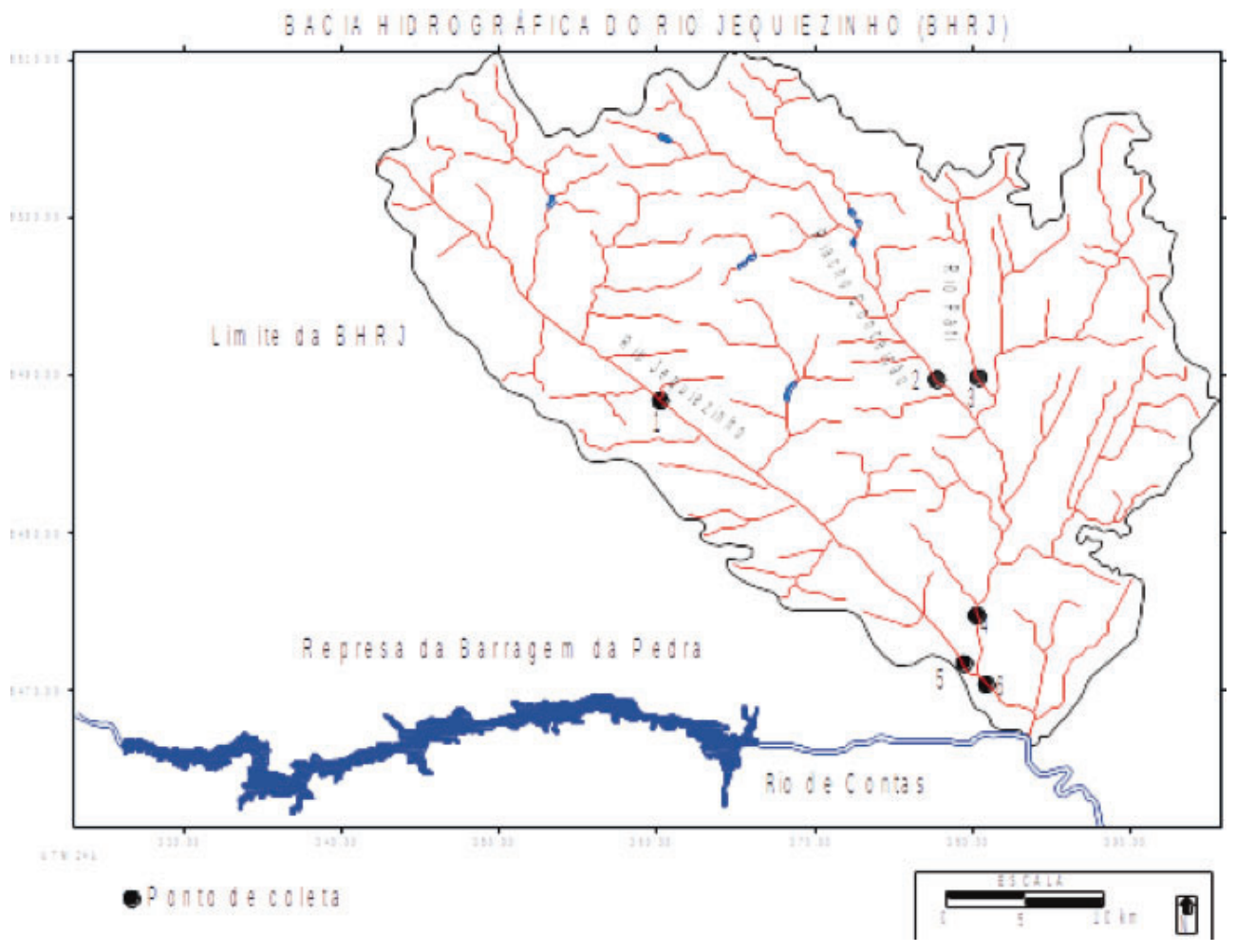

Fonte: elaborado pelos autores.

Essa bacia origina-se nas nascentes do rio Jequiezinho, localizada em uma altitude de aproximadamente 800 m (município de Maracás), e atinge o seu patamar mais baixo nas imediações do município de Jequié, onde desemboca na margem esquerda do rio de Contas. O riacho Conceiçáo tem as suas nascentes no município de Lajedo do Tabocal e possui um curso de $47,71 \mathrm{~km}$ até desembocar no rio Pati. O Pati, por sua vez, nasce no município de Itiruçu e possui $20,72 \mathrm{~km}$ de extensão (Tabela 1). O rio Jequiezinho, após estender-se por $58,23 \mathrm{~km}$ (Tabela 1), tem sua confluência com o riacho Conceição e o rio Pati na zona rural do município de Jequié. O rio Jequiezinho desemboca no rio de Contas após atravessar a parte urbana de Jequié, sendo que, neste trecho, possui uma vazão perene e encontra-se retificado e canalizado, apresentando-se bastante impactado pela urbanizaçáo e consequente aporte de esgotos domésticos. Em um monitoramento da qualidade da água da bacia do rio de Contas, realizado em 2002; dos 12 pontos amostrados nesta bacia, 
o rio Jequiezinho foi o único a apresentar um comprometimento na qualidade de suas águas, sendo que o Índice de Qualidade da Água (IQA) foi classificado como "Ruim" e "Péssimo" em duas ocasióes da amostragem (BAHIA. CRA, 2002).

Os rios que compóem a BHRJ são de caráter temporário, ou seja, no período de chuvas, eles apresentam deflúvio, e no período de seca, o volume das águas diminui e eles secam, com execeção de um trecho do rio Jequiezinho, que se encontra próximo à sua desembocadura e é perene.

\section{Influência do hidroperíodo nas características limnológicas dos trechos do leito do rio com poças permanentes e temporárias}

A BHRJ é composta por rios intermitentes, dentre os quais o Jequiezinho, o Patí e o rio Conceição são seus principais afluentes. Atividades antrópicas (queimadas, irrigação, uso doméstico, degradação da mata ciliar e assoreamento) são frequentemente desenvolvidas no entorno destes sistemas aquáticos, sendo responsáveis por alterar as características físicas e químicas da água.

Esses sistemas são altamente biodiversos e mantêm flora e fauna aquáticas específicas. Neles encontram-se macroalgas e todos os tipos funcionais de macrófitas aquáticas (emersas, submersas, submersas com folhas flutuantes e flutuantes). A fauna compreende peixes, anfíbios, larvas de dípteros, coleópteros, gastrópodes, odonatas, ostrácodes, cladóceros, copépodes e rotíferos.

A sazonalidade constituiu um dos principais fatores que afetaram a variação das características ambientais da BHRJ, que apresenta duas estaçôes climáticas bem caracterizadas pela presença de chuva: uma úmida (ou chuvosa), de novembro a março (cinco meses); e uma seca, de abril a outubro (sete meses). Na estação seca, a média da precipitação variou de 23 $\mathrm{mm}$ (em outubro) a $68 \mathrm{~mm}$ (em maio), enquanto variou de $86 \mathrm{~mm}$ (em março) a $115 \mathrm{~mm}$ (em dezembro) na estação chuvosa. Períodos irregulares com picos de déficit hídrico podem apresentar secas extensas, alcançando até 11 meses de estiagem. Esta irregularidade caracteriza o fluxo dos rios e proporciona um funcionamento diferenciado destes ambientes entre os anos mais secos ou mais chuvosos. 
Esta variabilidade sazonal define o hidroperíodo (período úmido dos ambientes aquáticos temporários), principal fator que influencia na composição e estrutura das comunidades aquáticas em ambientes temporários. A Figura 2 apresenta a profundidade dos ambientes estudados e a precipitaçáo da regiáo no período de estudo. Os pontos 1, 2 e 6 foram trechos do rio que não secaram (poças permanentes), enquanto os pontos $3,4 \mathrm{e}$ 5 secaram em um determinado período do estudo (fevereiroa maio/2003, abril a agosto/2003 e agosto/2003, respectivamente).

FIGURA 2 - Variação da precipitação e da profundidade dos pontos amostrados

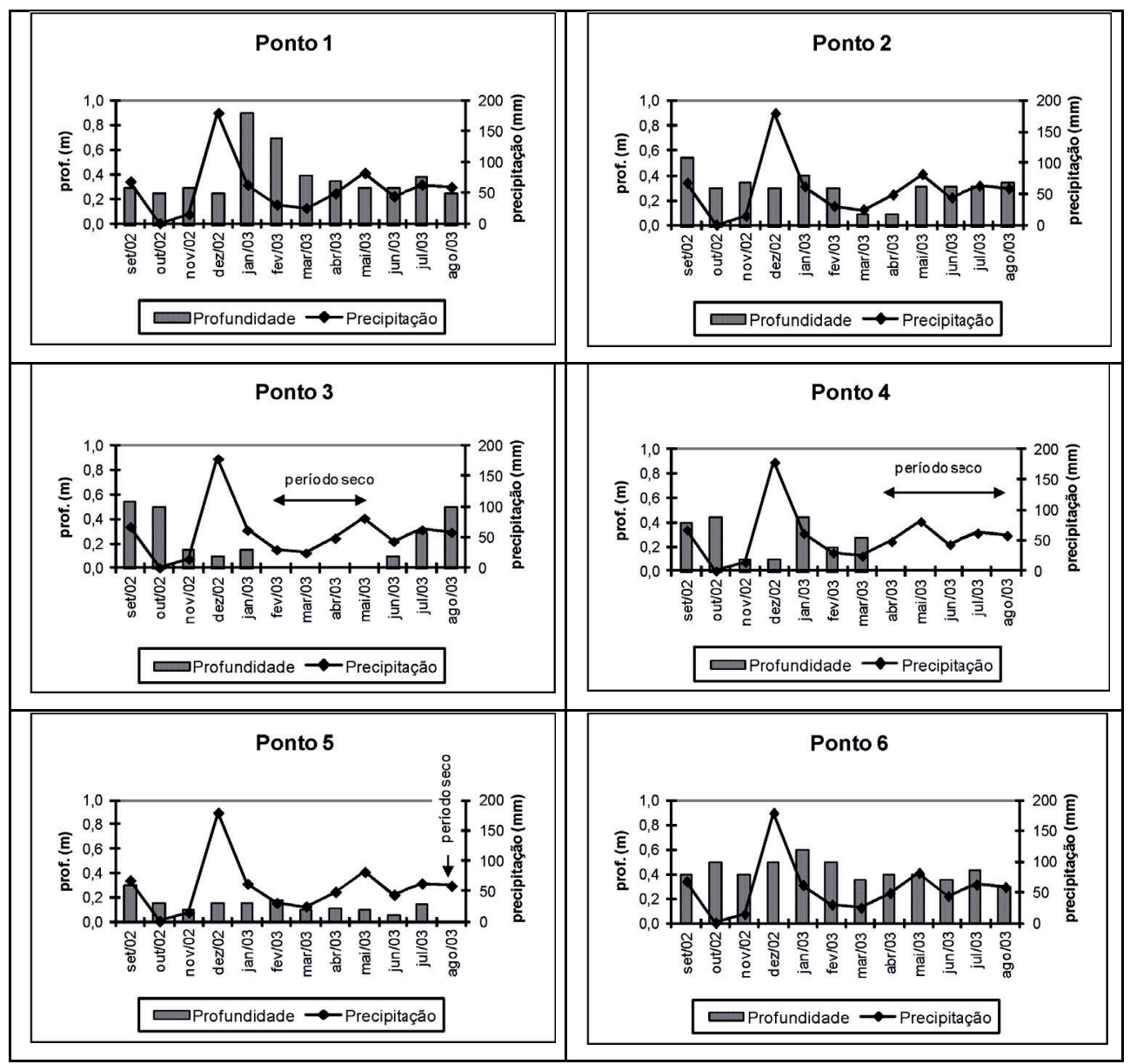

A intermitência do rio Jequiezinho e seus afluentes e a consequente formaçáo, e eventual processo de secagem, das poças nosleitos destes podem ter sido resultantes do balanço hídrico durante o período de estudo, 
que geralmente ocorre nas regióes semiáridas. A causa da intermitência dos rios também pode ser atribuída à redução do nível do lençol freático durante o período seco (ROSÁRIO; RESH, 2000).

Esta intermitência produz uma elasticidade hidrológica através de movimentos de expansão e contração dos ambientes aquáticos (STANLEY; FISHER; GRIMM, 1997), tornando os rios intermitentes extremamente dinâmicos. No entanto, a dinâmica hidrológica dos rios temporários, caracterizada pela ausência de fluxo, apresenta dois extremos: um, com presença de fluxo de água; e outro, com fluxo inexistente devido à perda total de água do ambiente (seca). O processo de seca que promove a descontinuidade dos rios é um evento natural, mas pouco se sabe sobre seu efeito nas comunidades e sobre o funcionamento dos rios (LAKE, 2003; HUMPHRIES; BALDWIN, 2003). Assim como a seca, as inundaçóes repentinas provocadas pelas chuvas torrenciais desempenham um importante papel nos rios temporários. Segundo Humphries e Baldwin (2003), a seca e a inundaçáo representam extremos em um contínuo hidrológico, sendo os efeitos da seca, muitas vezes previsíveis, enquanto os eventos e efeitos da inundaçáo surgem repentinamente e são imprevisíveis. Como verificado na BHRJ, a seca interrompe a conectividade hidrológica e pode estar influenciando nos processos ecológicos ao longo do rio (LAKE, 2003).

Os rios intermitentes da bacia do rio Jequiezinho apresentaram mudanças em suas características, sendo a sazonalidade climática o principal fator de transformação da fisionomia destes ambientes e das características químicas e físicas da água nos diferentes pontos amostrados. A Tabela 2 apresenta um resumo das variáveis analisadas. 
TABELA 2 - Resumo das variáveis físicas e químicas da água nos pontos amostrados na Bacia Hidrográfica do Rio Jequiezinho (setembro de 2002 a agosto de 2003)

\begin{tabular}{l|l|r|r|r|r|r|r|r|r|r|r}
\hline & & Tar & \multicolumn{1}{|c|}{ TA } & pH & AT & \multicolumn{1}{c|}{ CE } & OD & Prof & MST & MSO & MSI \\
\hline ponto 1 & média & 27.3 & 24.3 & 7.6 & 2.4 & 4721.7 & 5.5 & 0.5 & 11.6 & 5.9 & 5.7 \\
\hline & des.pad & 3.0 & 1.9 & 0.2 & 0.7 & 957.1 & 2.4 & 0.3 & 5.3 & 2.7 & 3.0 \\
\hline & mínimo & 23.4 & 21.6 & 7.3 & 1.0 & 2940.0 & 1.9 & 0.3 & 5.8 & 3.8 & 1.6 \\
\hline & máximo & 32.5 & 26.7 & 7.9 & 3.9 & 6860.0 & 9.9 & 0.9 & 25.4 & 13.1 & 12.3 \\
\hline ponto 2 & média & 30.9 & 26.3 & 7.7 & 3.1 & 4662.5 & 7.9 & 0.81 & 39.9 & 23.9 & 15.9 \\
\hline & des.pad & 4.0 & 2.6 & 0.3 & 0.5 & 443.0 & 2.9 & 0.3 & 49.5 & 36.8 & 13.2 \\
\hline & mínimo & 25.1 & 21.5 & 7.3 & 2.3 & 4070.0 & 4.8 & 0.4 & 8.4 & 5.8 & 2.6 \\
\hline & máximo & 36.4 & 29.7 & 8.3 & 4.2 & 5255.0 & 15.4 & 1.3 & 193.3 & 139.3 & 54.0 \\
\hline ponto 3 & média & 33.5 & 26.4 & 7.4 & 2.6 & 3923.3 & 4.8 & 0.4 & 19.1 & 10.3 & 8.8 \\
\hline & des.pad & 4.7 & 3.1 & 0.6 & 1.9 & 1596.8 & 3.1 & 0.2 & 18.9 & 8.9 & 11.4 \\
\hline & mínimo & 26.0 & 23.1 & 6.5 & 0.5 & 2260.0 & 2.0 & 0.0 & 3.4 & 1.8 & 1.2 \\
\hline & máximo & 40.5 & 31.3 & 8.0 & 5.3 & 6780.0 & 11.6 & 0.6 & 46.6 & 21.3 & 28.3 \\
\hline ponto 4 & média & 33.8 & 28.1 & 7.8 & 1.1 & 6517.1 & 10.5 & 0.30 & 174.1 & 118.1 & 56.0 \\
\hline & des.pad & 4.5 & 3.5 & 0.4 & 0.8 & 2213.6 & 3.8 & 0.2 & 274.2 & 188.3 & 86.0 \\
\hline & mínimo & 27.0 & 20.4 & 7.3 & 0.1 & 4020.0 & 4.5 & 0.0 & 7.8 & 4.2 & 1.4 \\
\hline & máximo & 38.6 & 32.4 & 8.4 & 2.4 & 9480.0 & 16.6 & 0.5 & 746.7 & 513.3 & 233.3 \\
\hline ponto 5 & média & 32.8 & 28.6 & 7.7 & 1.4 & 6653.2 & 12.9 & 0.13 & 302.8 & 173.9 & 125.1 \\
\hline & des.pad & 4.6 & 3.2 & 0.8 & 1.2 & 1370.5 & 4.3 & 0.1 & 213.4 & 139.0 & 80.2 \\
\hline & mínimo & 26.4 & 24.1 & 6.3 & 0.2 & 5460.0 & 5.4 & 0.0 & 37.5 & 11.7 & 19.0 \\
\hline & máximo & 37.7 & 32.4 & 9.0 & 3.4 & 10210.0 & 18.7 & 0.3 & 600.0 & 360.0 & 260.0 \\
\hline ponto 6 & média & 33.0 & 28.8 & 7.8 & 2.8 & 4927.5 & 9.7 & 0.4 & 11.9 & 6.6 & 5.3 \\
\hline & des.pad & 4.2 & 2.9 & 0.2 & 0.5 & 949.8 & 2.1 & 0.1 & 3.3 & 2.3 & 2.9 \\
\hline & mínimo & 25.2 & 24.5 & 7.5 & 2.0 & 4270.0 & 6.6 & 0.3 & 5.8 & 3.8 & 2.0 \\
\hline & máximo & 37.7 & 33.5 & 8.1 & 3.5 & 7850.0 & 13.5 & 0.6 & 17.4 & 11.2 & 10.8 \\
\hline
\end{tabular}

Fonte: Dados da pesquisa.

* Tar - Temperatura do $\operatorname{Ar}\left({ }^{\circ} \mathrm{C}\right)$; TA - Temperatura da Água $\left({ }^{\circ} \mathrm{C}\right) ; \mathrm{pH}$, AT -Alcalinidade (Meq.L-1); CE

- Condutividade Elétrica da Água ( $\mu$ S.cm-1); OD -Oxigênio Dissolvido (mg.L-1); Prof. - Profundidade de Coleta (m); MST -Material em Suspensão Total (mg.L-1); MSO - Material Orgânico em Suspensão (mg.L-1) e MSI - Material Inorgânico em Suspensão (mg.L-1).

A temperatura média da água foi de $27,0^{\circ} \mathrm{C}$ e variou de $20,4^{\circ} \mathrm{C}$, no ponto 4 da estação seca (inverno), a $33,5^{\circ} \mathrm{C}$, no ponto 6 da estação chuvosa (verão). A temperatura da água dos ambientes intermitentes nas regiôes semiáridas é uma característica importante porque pode definir o conjunto de espécies potencialmente capazes de sobreviver nestes ambientes. 
Medeiros e Maltchik (2001), também estudando um rio intermitente na região semiárida do Brasil, encontraram temperaturas de água similares (entre $24^{\circ} \mathrm{C}$ e $37^{\circ} \mathrm{C}$ ) às encontradas na BHRJ.

As flutuações sazonais impõem o ritmo de variação da profundidade, tanto nos ambientes perenes quanto nos intermitentes, pois a evaporação diminui o volume de água e, consequentemente, a profundidade dos rios e suas poças. A profundidade mínima foi de zero metros nos pontos que secaram, e a profundidade máxima foi de $1,25 \mathrm{~m}$ no ponto 2 (Figura 2).

$\mathrm{O}$ pH da água apresentou ampla variação, de 6,29 a 9,02, e média de 7,65. No ponto 5, foi observada a maior amplitude de variação do $\mathrm{pH}$, e na estação chuvosa, uma tendência para alcalino. Um aspecto relevante com relação à variabilidade do $\mathrm{pH}$ nos rios intermitentes, tanto ao longo do ano quanto no período de 24 horas, é que as suas variaçóes são decorrentes de processos naturais devido às modificaçóes nos processos ecossistêmicos, tal como produtividade primária.

A alcalinidade total apresentou uma média de 2,29 meq. $\mathrm{L}^{-1}$ e uma variação de 0,07 a 5,34 meq. $\mathrm{L}^{-1}$. Os maiores valores ocorreram na época chuvosa, e o ponto que mais sofreu variação ao longo do ano foi o ponto 3. $\mathrm{Na}$ BHRJ, a alcalinidade demonstrou uma alta variabilidade temporal e uma tendência para apresentar maiores valores nos pontos perenes, indicando que são ambientes mais tamponados do que os pontos intermitentes.

A condutividade elétrica da água apresentou-se elevada, com uma média de 5.218,28 $\mu \mathrm{S} . \mathrm{cm}^{-1}$, variando de 2.260 a $10.210 \mu \mathrm{S} . \mathrm{cm}^{-1}$. Os pontos perenes apresentaram valores intermediários de condutividade; os pontos 4 e 5 apresentaram os maiores valores; e o ponto 3 apresentou os menores valores. Esta variável é uma característica física amplamente mensurada nos corpos hídricos de água doce. Embora ela avalie a capacidade da água em conduzir eletricidade, muitos trabalhos têm relacionado a condutividade com o estado trófico do ambiente, pois uma maior condutividade indica mais íons, que podem estar relacionados com o processo de eutrofização. Nos rios intermitentes da BHRJ, os valores mais elevados de condutividade estiveram relacionados com o período de déficit hídrico devido à maior concentraçáo de íons em função da redução do volume das poças.

$\mathrm{O}$ oxigênio dissolvido na bacia variou de $1,90 \mathrm{mg} . \mathrm{L}^{-1}$, no ponto 1 , a 18,70 mg. $\mathrm{L}^{-1}$, no ponto 5 . Os valores de oxigênio dissolvido apresentaram maiores variaçóes do que aqueles encontrados nos rios intermitentes 
estudados por Medeiros e Maltchik (2001) que oscilaram entre 6 e 9 mg. $L^{-1}$, e Rosário e Resh (2000), entre 6,4 e 9 mg.L.-1.

A média de material em suspensão total foi de $94,14 \mathrm{mg} . \mathrm{L}^{-1}$, porém seus valores variaram de 3,40 mg. $\mathrm{L}^{-1}$ a 746,67 mg. $\mathrm{L}^{-1}$. A variabilidade entre os ambientes é um reflexo das condiçóes da água em cada ponto: os pontos perenes (1, 2 e 6$)$ e o ponto 3 apresentaram menos material em suspensão do que os pontos intermitentes (4 e 5). Dentre as fraçóes orgânicas e inorgânicas, observou-se um predomínio de material orgânico.

A análise de componentes principais extraiu três eixos com uma porcentagem acumulada de explicação de $89,56 \%$, sendo que os dois primeiros eixos (Tabela 3) explicaram 79,36\% da variabilidade dos dados. A ordenação dos pontos no espaço bidimensional (Figura 3) apresentou as seguintes tendências:

Os pontos perenes (1, 2 e 6$)$ correlacionaram-se positivamente com alcalinidade e profundidade; e negativamente, com MST, condutividade elétrica da água e com os desvios padrôes das variáveis.

Os pontos intermitentes 4 e 5 apresentaram correlaçáo positiva com o MST, condutividade elétrica da água, temperatura da água, oxigênio dissolvido e com os desvios padrôes, e correlação negativa com a profundidade e alcalinidade.

O ponto 3, também intermitente, apresentou características intermediárias entre os pontos perenes $(1,2$ e 6 ) e os pontos intermitentes (4 e 5) devido aos baixos valores de $\mathrm{pH}$ e oxigênio dissolvido e à alta variabilidade da alcalinidade. 
TABELA 3 - Resumo da análise de componentes principais, realizada a partir das médias e desvios padrões mensais das variáveis físicas e químicas da água da Bacia Hidrográfica do Rio Jequiezinho (2002-2003)

\begin{tabular}{l|c|c|c}
\hline & Eixo 1 & Eixo 2 & Eixo 3 \\
\hline \multicolumn{3}{|c|}{ Variabilidade dos dados } \\
\hline Autovalor & 8.282 & 2.828 & 1.428 \\
\hline Porcentagem & 59.156 & 20.202 & 10.200 \\
\hline Porcentagem acumulada & 59.156 & 79.358 & 89.558 \\
\hline \multicolumn{4}{|c|}{ Correlaçáo } \\
\hline Temperatura da água (TA) & 0.256 & 0.173 & 0.493 \\
\hline Desvio padrão da TA & 0.276 & -0.108 & 0.278 \\
\hline pH & 0.106 & 0.563 & -0.049 \\
\hline Desvio padrão do pH & 0.253 & -0.280 & -0.005 \\
\hline Alcalinidade total (AT) & -0.308 & 0.015 & 0.293 \\
\hline Desvio padráo da AT & 0.077 & -0.573 & 0.094 \\
\hline Oxigênio dissolvido (OD) & 0.288 & 0.301 & 0.088 \\
\hline Desvio padrão do OD & 0.300 & -0.148 & -0.291 \\
\hline Material em suspensáo total (MST) & 0.320 & 0.018 & -0.169 \\
\hline Desvio padrão do (MST) & 0.319 & 0.063 & -0.286 \\
\hline Condutividade elétrica (CE) & 0.311 & 0.210 & -0.215 \\
\hline Desvio padrão da CE & 0.248 & -0.188 & -0.097 \\
\hline Profundidade (P) & -0.290 & 0.189 & -0.169 \\
\hline Desvio padrão da Profundidade (P) & -0.250 & -0.056 & -0.543 \\
\hline Fons &
\end{tabular}

Fonte: Dados da pesquisa. 
FIGURA 3 - Distribuição dos pontos amostrados em dois eixos da análise de componentes principais e os autovetores representados pelas setas

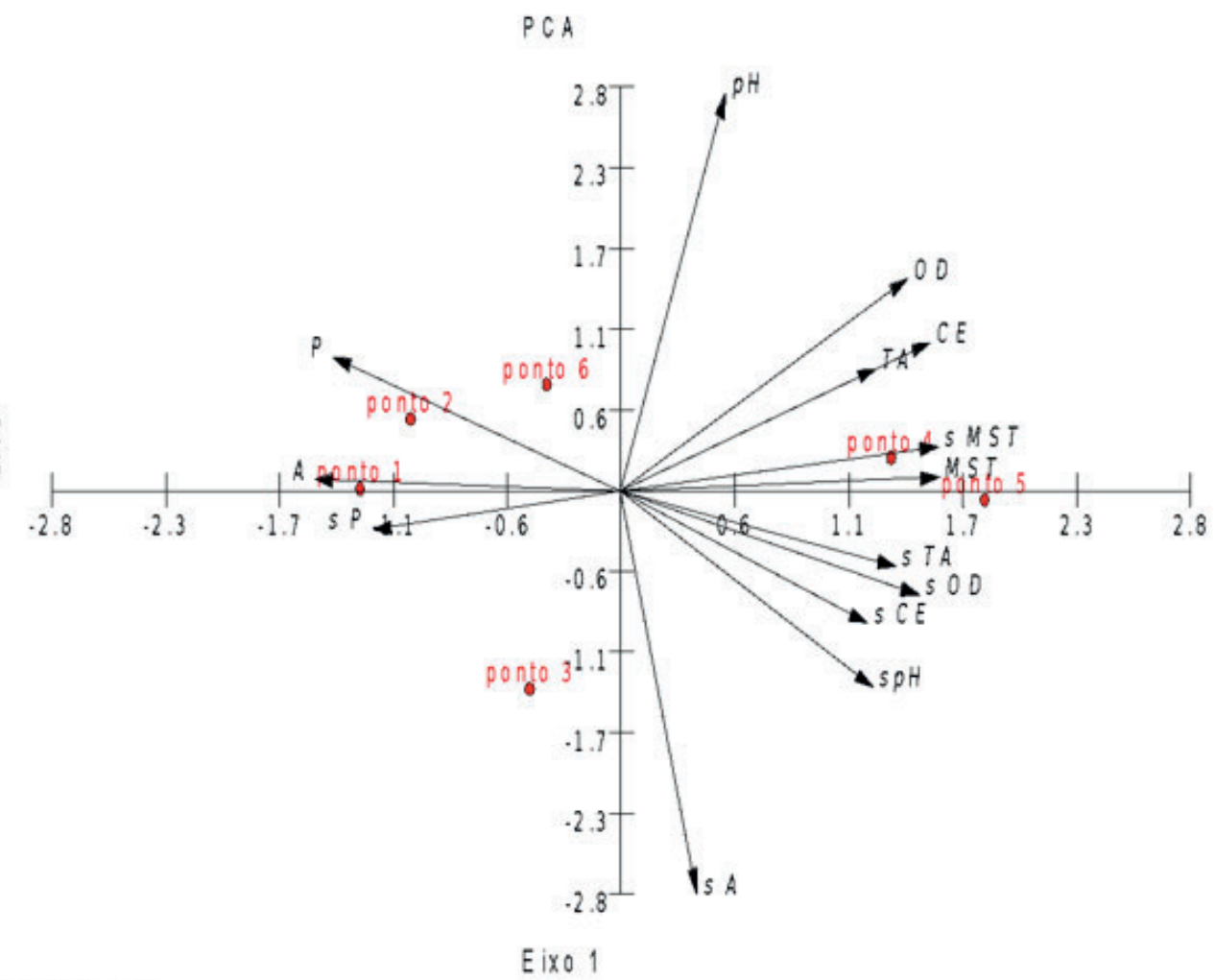

Scating: 4.97

Fonte: Dados da pesquisa.

* P - Profundidade, A - Alcalinidade, $\mathrm{pH}, \mathrm{OD}$ - Oxigênio dissolvido, TA - Temperatura da água, CE Condutividade elétrica, MST - Material em Suspensão Total). O s significa o desvio padrão da respectiva variável.

O Eixo 1 representou o hidroperíodo e foi responsável pela maior parte da variabilidade ambiental (WILLIAMS, 1999). A maior instabilidade ambiental dos pontos intermitentes (4 e 5), ordenados no lado positivo do Eixo 1, está expressa pelas elevadas correlaçóes dos desvios padróes das variáveis ambientais estudadas (Material em Suspensão, Condutividade Elétrica, Oxigênio Dissolvido, Temperatura e $\mathrm{pH}$ ). Os pontos perenes (1, 2 e 6) localizados no lado negativo do Eixo 1 só apresentaram correlação elevada com o desvio padrão da profundidade, mostrando que, apesar da variaçáo da profundidade nestes pontos, náo houve ampla variação nas demais variáveis ambientais, indicando que os 
pontos perenes são ambientes mais estáveis do que os pontos intermitentes. Podrabsky, Hrbek e Hand (1998) também verificaram que poças permanentes oscilam menos em suas variáveis físicas e químicas do que as poças efêmeras.

\section{Composiçáo e diversidade de microcrustáceos}

Um total de 30 taxa de microcrustáceos foi identificado (Quadro 1) na BHRJ, distribuído entre a subclasse Cladocera e a classe Copepoda, sendo esta última representada pelas ordens Cyclopoida, Calanoida e Harpacticoida. O número de taxa pode aumentar quando os membros da família Chydoridae forem identificados ao nível de espécie. A classe Copepoda foi a mais representativa em número de taxa, com 21 espécies registradas, sendo 17 espécies de ciclopoides.

QUADRO 1 - Lista de taxa (Cladocera e Copepoda) encontrados na Bacia Hidrográfica do Rio Jequiezinho (2002-2003).

\begin{tabular}{|l|}
\hline Copepoda Calanoida \\
\hline Argyrodiaptomus azevedoi Wright, 1935 \\
\hline Notodiaptomus cearensis Wright, 1936 \\
\hline Notodiaptomus iheringi Wright, 1935 \\
\hline Copepoda Cyclopoida \\
\hline Ectocyclops cf. rubescens Brady, 1904 \\
\hline Eucyclops sp \\
\hline Halicyclops cf venezuelaensis Lindberg, 1954a \\
\hline Mesocyclops cf ellipticus Kiefer, 1936d \\
\hline Mesocyclops longisetus longisetus Thiébaud, 1914 \\
\hline Mesocyclops meridianus Kiefer, 1926 \\
\hline Mesocyclops sp \\
\hline Metacyclops sp \\
\hline Copepoda Calanoida \\
\hline Microcyclops alius Kiefer, 1935 a \\
\hline Microcyclops cf ciebaensis Marsh, 1919 \\
\hline Microcyclops anceps \\
\hline Microcyclops anceps anceps Richard, 1897 \\
\hline
\end{tabular}




\begin{tabular}{|l|}
\hline Copepoda Calanoida \\
\hline Thermocyclops inversus Kiefer, 1929 \\
\hline Thermocyclops minutus Lowndes, 1934 \\
\hline Thermocyclops sp \\
\hline Thermocyclops cf tenuis Marsh, 1910 \\
\hline Thermoyclops cf brehmi Kiefer, 1927 \\
\hline Copepoda Harpacticoida \\
\hline Cladocera \\
\hline Ceriodaphnia cornuta Sars, 1886 \\
\hline Daphnia gessneri Herbst, 1967 \\
\hline Latonopsis australis Sars 1888 \\
\hline Macrothrix laticornis Jurine, 1820 \\
\hline Macrothrix superaculeata Smirnov, 1992 \\
\hline Macrothrix triserialis Brady, 1886 \\
\hline Moinodaphnia macleayi King, 1853 \\
\hline Simocephalus latirostris Stingelin, 1906 \\
\hline Chydoridae Stebbing, 1902 \\
\hline
\end{tabular}

Fonte: Dados da pesquisa.

As espécies mais frequentes foram Latonopsis australis, Microcyclops alius, Ceriodaphnia cornuta e Halicyclops venezuelaensis, indicando que estão fisiologicamente ajustadas para tolerar variaçóes no ambiente temporário. Os processos responsáveis pela distribuição dos organismos em corpos de água temporários não são claros. Estudos experimentais sugeriram que estes processos estão associados com a chegada e a persistência dos organismos dentro de um corpo de água específico (HOLLAND; JENKINS, 1998).

A diversidade de espécies estimada pelo extrapolador de riqueza de Jackknife e pelo índice de diversidade de Shannon apresentaram maiores valores nos pontos 3 e 4, ambos pontos intermitentes (Figura 4). As diferenças na diversidade são resultantes da heterogeneidade espacial e temporal (GRIMM, 1994). Ambientes com maior diversidade apresentaram regiôes pelágicas e marginais mais desenvolvidas e com presença de vegetação aquática. Assim, as variaçóes temporais subjacentes ao regime hidrológico que ocorrem durante o ano mudaram a heterogeneidade espacial do meio ambiente e estabeleceram nichos temporais para as diferentes espécies, aumentando a diversidade local. 
FIGURA 4 - Parâmetros utilizados para análise das assembleias nos pontos amostrados da Bacia Hidrográfica do Rio Jequiezinho

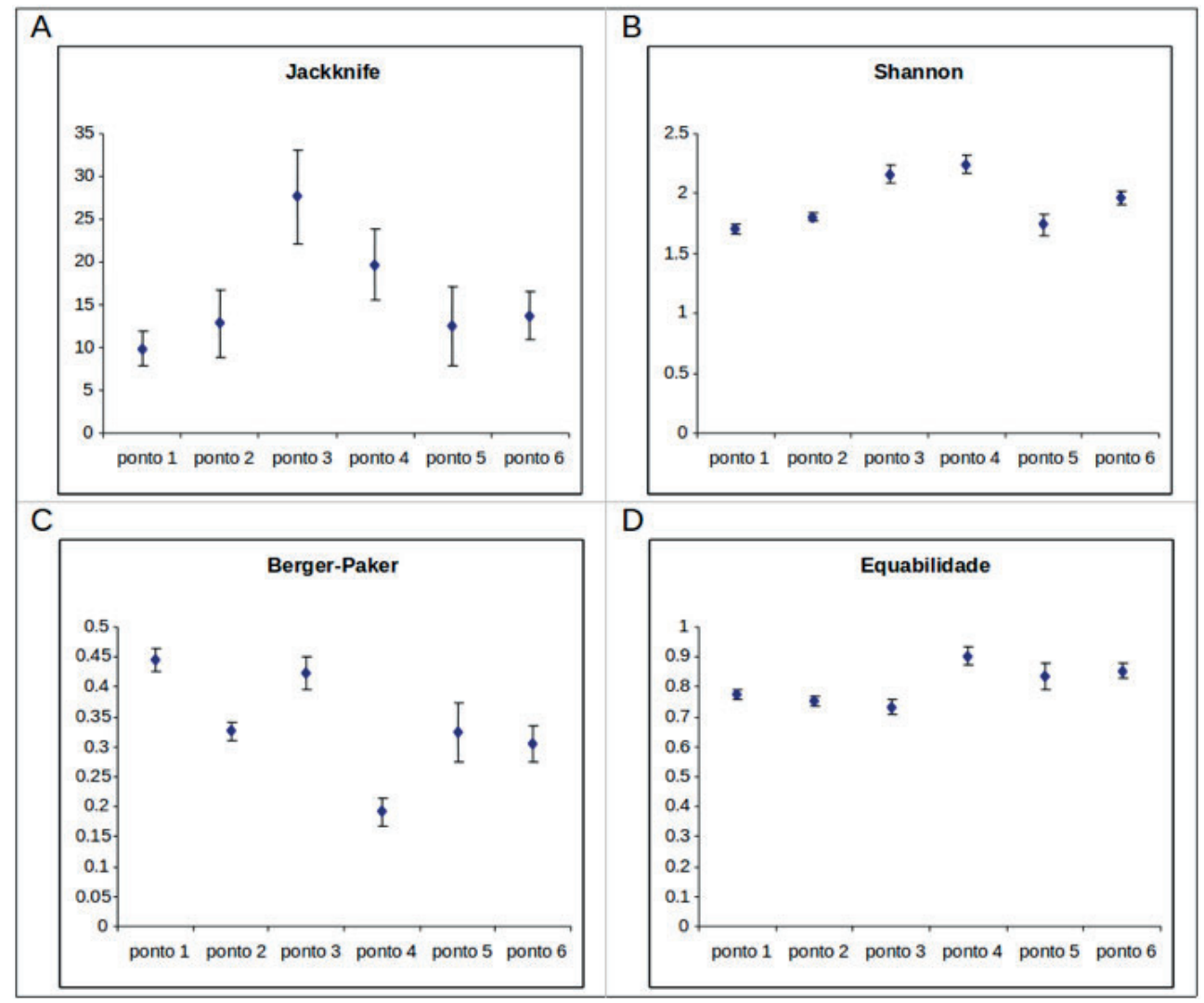

Fonte: Dados da pesquisa.

* A - Estimativa de Riqueza de Jackknife (número de espécies), B - Índice de Diversidade de Shannon (nats.ind-3), C - Índice de Dominância de Berger-Parker, D - Equitabilidade. O intervalo de confiança foi determinado pelo método de "bootstrap" a 95\%.

Os pontos mais a montante apresentaram uma menor Equabilidade e maior Índice de Berger-Parcker do que os pontos a jusante, ou seja, os pontos a montante apresentaram maior dominância. Este padráo espacial pode estar relacionado com a Teoria do Rio Contínuo ou as condiçóes ambientais mais estressantes nos ambientes a jusantes na BHRJ, não permitindo o estabelecimento de espécies específicas. Segundo Simões, Sonoda e Ribeiro (2011), estas diferenças estáo relacionadas a melhores condiçóes para os microcrustáceos nos locais a montante do que a jusante, porque a melhor qualidade dos recursos contribui para um melhor desenvolvimento de organismos nas cabeceiras, enquanto os locais a jusante são mais 
influenciados pela descarga fluvial durante a estação chuvosa e tornam-se menos favoráveis para o desenvolvimento de organismos planctônicos. Por exemplo: fatores físicos, tais como uma grande quantidade de sólidos em suspensão, a variabilidade na condutividade elétrica e o $\mathrm{pH}$ da água, tornam o ambiente mais restritivo para estes organismos.

Em geral, a diversidade tende a diminuir em ecossistemas fisicamente controlados nos quais características físicas e químicas são fatores limitantes, e tende a aumentar em ecossistemas biologicamente controlados. Nos ambientes temporários, os organismos são submetidos a forte seleção natural (NIX; JENKINS, 2000) e as assembleias são resultado de interaçôes entre a frequência e a intensidade dos distúrbios.

\section{Comentários Finais}

Há pouca informação sobre riachos tropicais temporários no Brasil, apesar de serem ecologicamente interessantes devido à sua variabilidade espacial e temporal, e podem ser apropriados para o desenvolvimento e aplicação de teorias ecológicas. Além disso, esses hábitats temporários podem fornecer um hábitat para agrupamentos importantes de espécies raras e/ou ameaçadas de extinção. Sob estas circunstâncias, a importância biológica dos ambientes aquáticos temporários é clara, uma vez que tais grupos fornecem abrigo e desempenham um papel importante na manutenção da diversidade regional de ambientes aquáticos. 


\section{Referências}

BAHIA. CENTRO DE RECURSOS AMBIENTAIS - CRA. Avaliaçáo da qualidade das águas - Relatório Técnico. Salvador -BA: CRA, 2002.

BARBOSA, J. E. L. et al. Aquatic systems in semi-arid Brazil: limnology and management. Acta Limnologica Brasiliensia, v. 24, n. 1, p. 103-118, 2012.

CIRILO, J. A. Políticas públicas de recursos hídricos para o semiárido. Estudos Avançados, São Paulo-SP, v. 22, n. 63, p. 61-82, 2008.

GRIMM, N. B. Disturbance, succession and ecosystem processes in streams: a case study from the desert. In: GILLER, P. S.; HILDREW, A. G.; RAFFAELLI, D. G. (Eds.). Aquatic ecology: scale, pattern and process. London: Blackwell Science, 1994. p. 93-112.

HOLLAND, T. A.; JENKINS, D. G. Comparison of processes regulating zooplankton assemblages in new freshwater pools. Hydrobiologia, $\mathrm{v}$. 387-388, p. 207-214, 1998.

HUMPHRIES, P.; BALDWIN, D. S. Drought and aquatic ecosystems: an introduction. Freshwater Biology, v. 48, n.7, p. 1141-1146, 2003.

INSTITUTO BRASILEIRO DE GEOGRAFIA E ESTATÍSTICA IBGE. Levantamento de Recursos Naturais. RADAMBRASIL. Suplemento Folha SD 24 - Salvador, v. 24. Rio de Janeiro: IBGE, 1999.

LAKE, P. S. Ecological of perturbation by drought in flowing water. Freshwater Biology, v. 48, n.7, p. 1161-1172, 2003.

LARNED, S. T. et al. Emerging concepts in temporary river ecology. Freshwater Biology, v. 55, n.4, p. 717-738, 2010.

MALTCHIK, L. Nossos rios temporários, desconhecidos, mas essenciais. Ciência Hoje, São Paulo-SP, v. 21, n. 122, p. 64-65, 1996.

MEDEIROS, E. S. F; MALTCHIK, L. Fish assemblage in an intermittently flowing stream from the Brazilian semiarid region. Austral Ecology, v. 26, n.2, p. 156-164, 2001.

MENESES, W. F. Semi-árido da Bahia. Pobreza econômica e exclusão social. Ciência Hoje, São Paulo-SPv. 21, n. 124, p. 46-52, 1996. 
NIX, M. H.; JENKINS, D. G. Life history of Daphnia obtusa from temporary ponds, cultured with a low-quality food. Aquatic Ecology, v. 34, n.1, p. 19-27, 2000.

PODRABSKY, J. E.; HRBEK, T.; HAND, S. C. Physical and chemical characteristics of ephemeral ponds habitats in the Maracaibo basin and Llanos region of Venezuela. Hydrobiologia, v. 362, n.1, p. 67-78, 1998.

ROSÁRIO, R. B. B.; RESH, V. H. Invertebrates in intermittent and perennial streams: is the hyporheic zone a refuge from drying? J. N. Am. Benthol. Soc., v. 19, n. 4, p. 680-696, 2000.

SHIEL, R. J.; GREEN, J. D.; NIELSEN, D. L. Floodplain biodiversity: why are there so many species? Hydrobiologia, v. 387-388, p. 39-46, 1998.

SIMÓES, N. R.; SONODA, S. L.; RIBEIRO, M. M. S. Spatial and seasonal variation of microcrustaceans (Cladocera and Copepoda) in intermittent rivers in the Jequiezinho river hydrographic basin, in the Neotropical semiarid. Acta Limnol. Bras, v. 20, n. 3, p. 197-204, 2008.

SIMÓES, N. R.; SONODA, S. L.; RIBEIRO, M. M. S. Diversity and structure of microcrustacean assemblages (Cladocera and Copepoda) and limnological variability in perennial and intermittent pools in a semi-arid region, Bahia, Brazil. Iheringia, Série Zoologia, Porto Alegre-RS, v. 101, n. 4, p. 317-324, 2011.

STANLEY, E. H.; FISHER, S. G.; GRIMM, N. B. Ecosystem expansion and contraction in streams. Bioscience, v. 47, n. 7, p. 427-435, 1997.

WILLIAMS, W. D. Conservation of wetlands in drylands: a key global issue. Aquatic Conservations and Freshwater Ecosystems, v. 9, n.6, p. 517-522, 1999.

WILLIAMS, D. D. Temporary ponds and their invertebrate communities. Aquatic Conservation Marine and Freshwater Ecosystems, v. 7, n.2, p. 105-117, 1997.

WILLIAMS, D. D. Introduction to temporary waters. In: WILLIAMS, D. D. The ecology of temporary waters. Portland, USA: Timber Press, 1987. p. 1-3. 


\title{
Importância das florestas ripárias na melhoria da qualidade da água em bacias hidrográficas: estudos de caso na regiáo central do estado de Sáo Paulo
}

\author{
Donato Seiji Abe \\ Jorge Luiz Rodrigues Filho \\ Leandro Contri Campanelli \\ Corina Sidagis-Galli \\ Douglas Murillo Marrara \\ Ricardo Milanetti Degani \\ Fernando Souza Soares \\ Benjamim Mattiazzi \\ José Galizia Tundisi
}

\section{Introduçáo}

O conceito de bacia hidrográfica como unidade de pesquisa e gerenciamento é resultado de longa evoluçáo, iniciada com a implementação do conceito de carga por Vollenweider (1968) e consolidada com os estudos de Likens (1984, 1992), a partir de experimentos realizados em pequenas bacias hidrográficas na Floresta Experimental de Hubard-Brook, nos Estados Unidos. Nesses estudos, verificou-se, por exemplo, a interconexão entre os processos envolvidos nessa unidade, como o transporte de fósforo e nitrogênio do ecossistema terrestre para o ecossistema aquático (LIKENS; BORMANN, 1974), ou seja, as características do ecossistema terrestre, tais como litologia, cobertura vegetal e uso e ocupação do solo, exercem forte influência sobre as variáveis dos corpos de água receptores inseridos na mesma bacia hidrográfica (TUNDISI; MATSUMURA-TUNDISI, 2010).

Como exemplo, o desmatamento de florestas naturais e de áreas alagadas reduz drasticamente a retenção de solo e de nitrogênio e fósforo na bacia 
de drenagem, causando um aumento da carga destes nos corpos receptores. Da mesma forma, grandes áreas agrícolas e de pastagens são responsáveis por elevadas taxas de exportaçáo de nutrientes para os corpos de água, resultantes do incremento do aporte destes somado à redução da retençáo hídrica na bacia de drenagem quando comparada a áreas de floresta. Carpenter et al. (1998) verificaram que $82 \%$ de nitrogênio e $83 \%$ de fósforo são provenientes de cargas difusas de área rurais nos Estados Unidos. No Brasil, estima-se que houve um aumento em $33 \%$ da produção agropecuária na última década, o que remete a um aumento da mesma ordem de grandeza na transferência de produtos químicos para os corpos de água (SHIGAKI; SHARPLEY; PROCHNOW, 2006).

\section{Florestas ripárias}

As florestas ripárias (mata ciliar e mata de galeria) que acompanham os cursos de água desempenham funçóes ecológicas, sociais e econômicas importantes nas bacias hidrográficas. O ciclo da água, a composição química da água de drenagem, o transporte de matéria orgânica para os cursos de água e a intensidade do escoamento superficial e da descarga dos aquíferos dependem diretamente das condiçôes da vegetação ripária, sua preservação e suas diversidade e densidade (TUNDISI; MATSUMURA-TUNDISI, 2010).

Todo o conjunto de processos ecológicos sustentado pelas florestas ripárias tem componentes econômicos fundamentais, tais como: renovação da qualidade da água, controle e recarga dos aquíferos e da água reposta por evapotranspiração; controle de sedimentação dos ecossistemas aquáticos e, portanto, preservação do volume de água; suprimento de matéria orgânica para a fauna íctia e manutenção dos estoques e diversidade dessa fauna, e diversidade da fauna terrestre e refúgio para esta, além de zona de reprodução (TUNDISI; MATSUMURA-TUNDISI, 2010).

Em áreas urbanas, as florestas ripárias e bosques também exercem papeis muito importantes por suas funções ecológicas, sociais, culturais, estéticas, históricas e turísticas (MATTIAZZI, 2009). Apesar de serem fisicamente limitados, esses sistemas prestam serviços essenciais, tais como a regularização hidrológica e redução das enchentes, a manutenção do microclima, a manutenção da fauna, a contenção de processos erosivos e a estabilização de encostas (SBPC, 2011). A vegetação presente nesses sistemas atenua a temperatura do ar, resultando em maior conforto térmico 
nos arredores, reduz os níveis de ruído, além de possibilitar lazer, ou seja, diminui os impactos ambientais da urbanização. Portanto, a criação ou recuperação desses espaços, bem como a sua manutenção, são fundamentais para o bem-estar da população.

Os serviços ecossistêmicos das florestas ripárias demonstrados neste capítulo são baseados em dois estudos de caso realizados na regiáo central do estado de São Paulo: uma floresta fica localizada na área urbana de São Carlos, referente à um bosque recuperado por uma associaçáo de moradores de um bairro; e a outra, localizada na bacia do ribeirão do Lobo, nos municípios de Brotas e Itirapina, referente a simulaçóes de alteraçóes da cobertura vegetal baseada nas premissas do atual Código Florestal (BRASIL. Lei 12.651/12).

\section{Recuperaçáo florestal e melhoria da qualidade da água em córrego urbano}

Um bom exemplo de recuperação de bosque urbano foi executado por uma associação de moradores de um bairro da cidade de São Carlos, localizado na região Central do estado de São Paulo (MATTIAZZI; FIGUEIREDO; KLEFASZ, 2011). No bairro Parque Santa Marta, há uma extensa área pública municipal denominada Bosque Cambuí, com aproximadamente 40.000 $\mathrm{m}^{2}$ (Figura 1). Até o início da década de 1990, a área era constituída predominantemente por gramíneas, com a presença de poucas espécies arbóreas nativas encontradas em um fragmento de mata ripária junto ao córrego do Cambuí. Nessas condiçóes, o córrego vinha sofrendo um processo contínuo de assoreamento em função dos processos erosivos na microbacia, além de sofrer impactos frequentes, como deposição de entulhos, pastagem de animais e queimadas intencionais frequentes.

Em 1993, por iniciativa de um grupo de moradores motivado a criar uma paisagem mais agradável para o bairro, a área do bosque do Cambuí foi sendo delimitada e arborizada gradualmente. Em 1998, sob a coordenação de Benjamim Mattiazzi, Professor da Universidade Federal de São Carlos, e de outros especialistas, a associação de moradores propôs a criação do projeto de recuperaçáo da mata ciliar dos mananciais urbanos Santa Maria do Leme e Cambuí. Estabeleceu-se uma parceria entre a associação de moradores e o Departamento de Política de Áreas Verdes da Secretaria Municipal de Obras e Serviços Públicos, a partir da qual foram plantadas 1.500 mudas de espécies nativas até 1999.

A área sofreu pequenos incêndios nos anos subsequentes, mas foi 
gradualmente recuperada com plantio de mais 4.300 mudas de espécies predominantemente nativas até 2002. Após várias melhorias no sistema de drenagem, na cobertura do solo, no controle de pragas e incêndios, bem como a manutenção da área a partir da parceria entre a associação dos moradores e a prefeitura municipal, a floresta foi gradualmente se estabelecendo, sobretudo no período entre 2012 e 2014; com alteraçóes visíveis na retenção de umidade no solo, na contenção de erosão, na diminuição do assoreamento dos rios e na mudança do microclima. Atualmente, o bosque conta com $83 \%$ de plantas de espécies nativas e 17\% de espécies exóticas.

Para avaliar a consequência da recuperação da floresta ripária no córrego Cambuí, um estudo foi conduzido entre 2012 e 2014, com coletas a jusante e a montante (Figura 1), visando avaliar as possíveis alteraçôes na qualidade da água em decorrência do aumento da capacidade de retenção de nutrientes. A primeira campanha foi realizada em setembro de 2012, e a segunda campanha foi realizada após dois anos, em agosto de 2014, com a vegetação já bastante consolidada.

FIGURA 1 - Localização do córrego do Cambuí na microbacia do córrego Santa Maria do Leme, área urbana de São Carlos-SP, e os pontos de amostragem de água

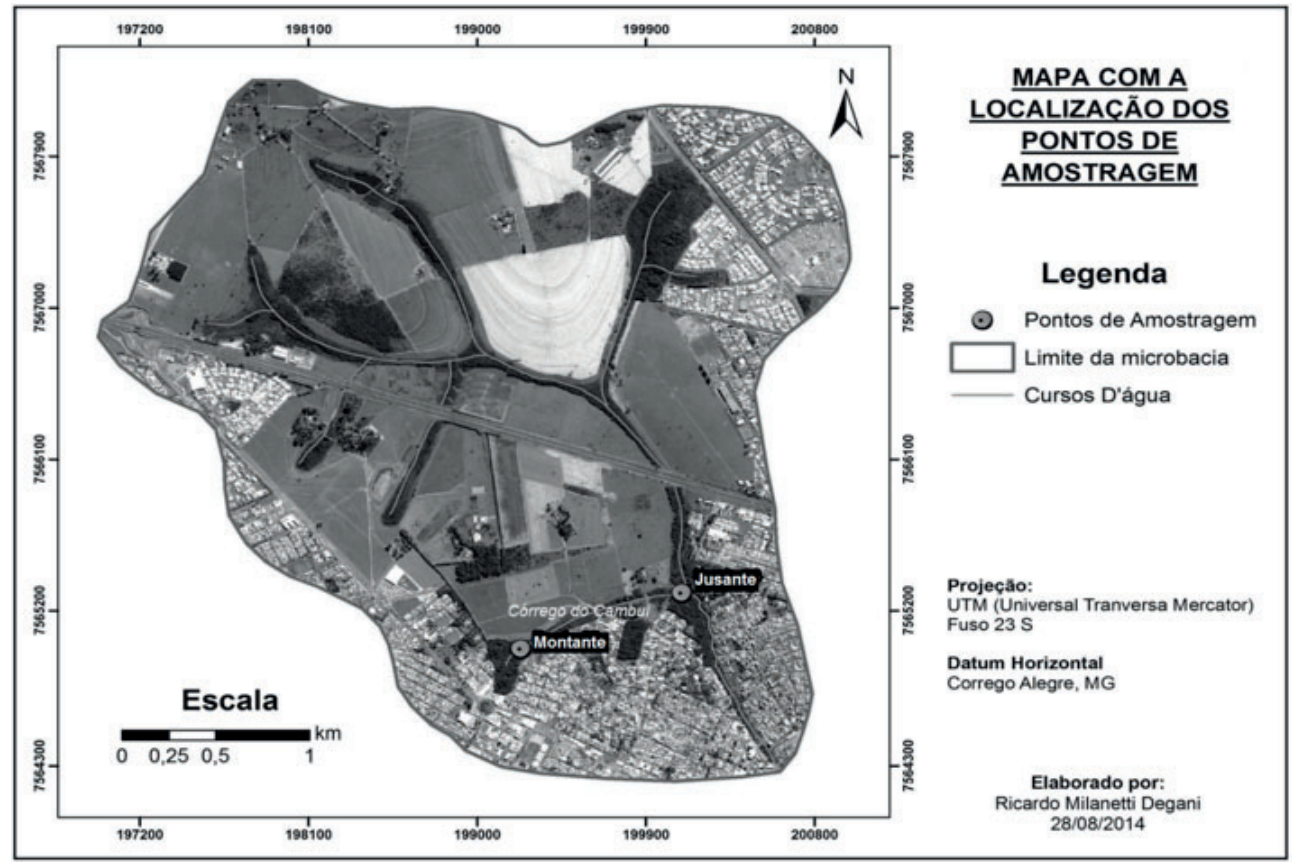

Fonte: elaborado pelos autores. 
Na Figura 2, estão apresentados os gráficos das concentrações de condutividade, oxigênio dissolvido, turbidez, nitrogênio total Kjeldahl, fósforo total e Escherichia coli, obtidas nos pontos a montante (próximo à nascente) e a jusante (próximo à foz) do córrego do Cambuí nas campanhas de setembro de 2012 e agosto de 2014 . Ao comparar os valores observados no ponto a montante com o ponto a jusante, verifica-se uma nítida capacidade de depuração da água para algumas variáveis em ambos os períodos: condutividade, nitrogênio total Kjeldahl e Escherichia coli sofreram um decaimento, e o oxigênio dissolvido sofreu um aumento da montante para a jusante do córrego Cambuí. Porém, a capacidade de depuração da floresta ripária tornou-se ainda mais evidente ao comparar os valores das variáveis de qualidade da água obtidos em setembro de 2012 com os valores obtidos em agosto de 2014 para ambos os pontos. Com o maior estabelecimento da floresta ripária em 2014, ela passou a exercer uma capacidade muito maior de depuração, o que demonstra a grande importância desses fragmentos na melhoria da qualidade da água.

Recentemente, o bosque do Cambuí e outras áreas de fragmentos remanescentes foram incluídos no Plano Diretor de São Carlos como Áreas de Especial Interesse Ambiental (AEIA), as quais constituem um corredor biológico urbano que permite a manutençáo da biodiversidade dos ecossistemas.

Esse exemplo demonstra que participações comunitárias bem coordenadas e com apoio do poder executivo são capazes de recuperar patrimônios ambientais de extrema relevância em áreas urbanas. 
FIGURA 2 - Concentraçóes de condutividade, oxigênio dissolvido, turbidez, nitrogênio total Kjeldahl, fósforo total e Escherichia coli obtidas nos pontos a montante (próximo à nascente) e a jusante (próximo à foz) do córrego do Cambuí nas campanhas de setembro de 2012 e agosto de 2014. Escherichia coli foi quantificada apenas em agosto de 2014

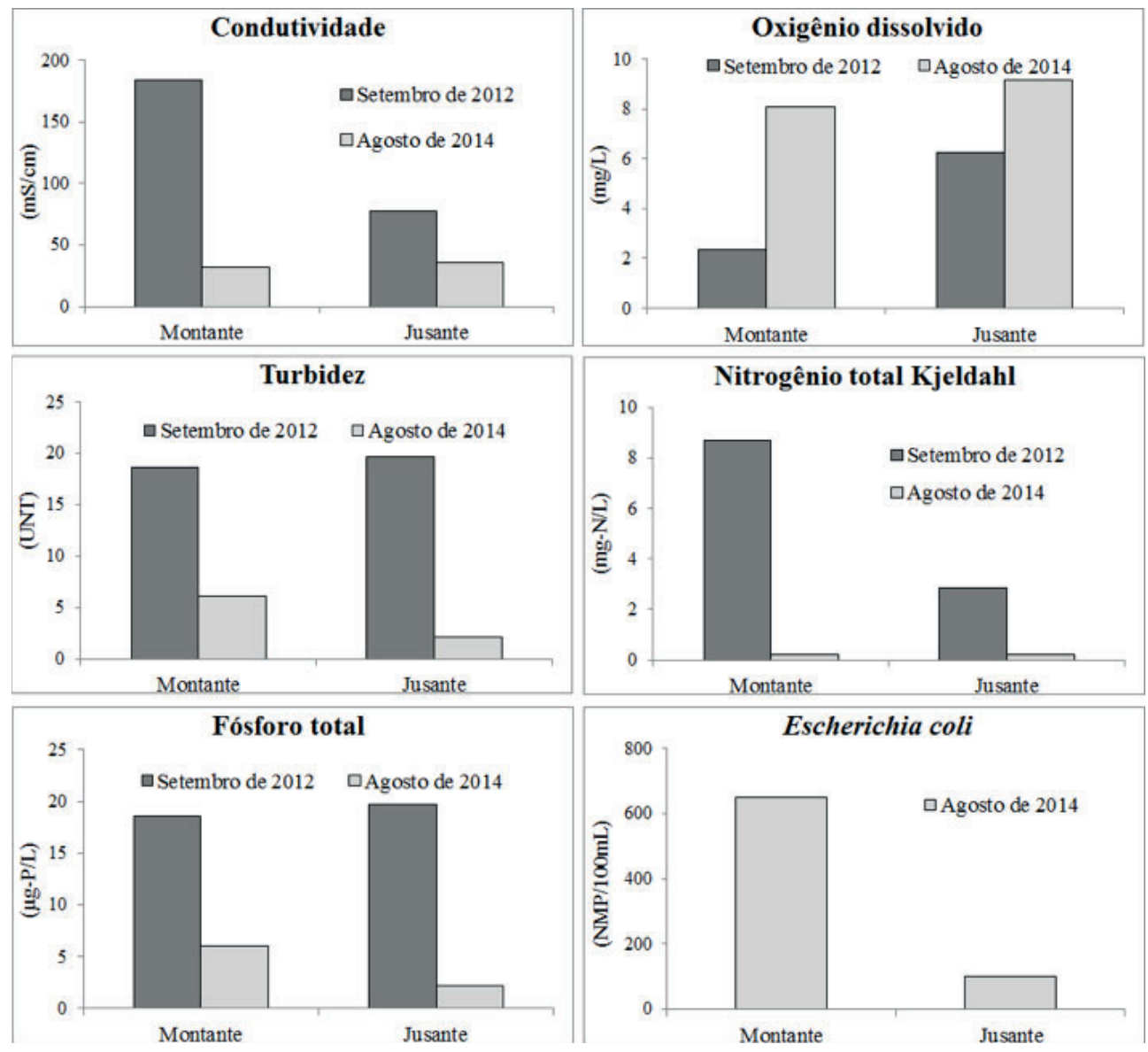

Elaboração: Donato Seiji Abe.

Fonte: Dados da pesquisa.

\section{Consequências da reduçáo de florestas ripárias para a qualidade da água}

Por causa de sua reconhecida importância, as florestas ripárias eram protegidas como Áreas de Preservação Permanente (APP) pela Lei 4.771, de 15 de setembro de 1965 (BRASIL. Lei 4.771/1965), pela Medida Provisória 2.166-67, de 24 de agosto de 2001 (BRASIL. Medida Provisória 
2166-67/2001) e pela Resolução CONAMA 303, de 20 de março de 2002 (BRASIL. Resolução CONAMA 303/2002). Porém, a recente alteração do Código Florestal pela Lei Federal 12.651/2012 (BRASIL. Lei 12.651/2012) que vislumbrava a permissão da substituição parcial de áreas de florestas ripárias às margens dos cursos hídricos por atividades agrícolas, levantou profunda preocupaçáo com a integridade dos ecossistemas aquáticos. Tal alteração poderia reduzir a açáo das florestas ripárias na retenção de nutrientes, podendo resultar no aumento da eutrofização dos corpos de água, com consequências negativas para os usos múltiplos.

Visando avaliar possíveis alteraçóes resultantes no uso da terra propostas pelo atual Código Florestal, Rodrigues Filho et al. (2015) estimaram as cargas difusas de nitrogênio total e fósforo total na bacia hidrográfica do ribeirão do Lobo, localizada na regiáo central do estado de São Paulo, para diferentes cenários de Áreas de Proteção Permanente na bacia, com base em coeficientes de exportaçáo do Modelo de Correlação entre Uso do Solo e Qualidade da Água (MQUAL) (SÃO PAULO. SMA, 2003).

Os cenários utilizados no modelo foram:

- Cenário 1 (cenário atual): com $30 \mathrm{~m}$ de floresta ripária em rios com até $50 \mathrm{~m}$ de largura.

- Cenário 2 (conservador): com APP de $50 \mathrm{~m}$ em torno das nascentes e ao longo de ambas as margens de corpos de água.

- Cenário 3: baseado na emenda ao Código Florestal (Seção 3, Subsecçâo 7) de que náo há obrigatoriedade de manter ou recuperar áreas de Reserva Legal em propriedades rurais com áreas inferiores a 4 módulos fiscais (cerca de 48 ha); seguindo essa premissa, áreas com vegetação natural (Reserva Legal) foram substituídas por áreas com atividades agrícolas. Este tipo de propriedade é predominante na bacia do ribeirão do Lobo. Por conseguinte, $20 \%$ da área total de bacia que correspondem à área indicada pela Lei Floresta de Reserva Legal foram subtraídas da área de vegetação natural e substituídas por áreas com atividades agrícolas.

As cargas difusas de Nitrogênio total ( $\mathrm{N}$ total) e Fósforo total (P total) foram estimadas com base nos coeficientes de exportação do MQUAL versão 1.5 (SÃO PAULO. SMA, 2003). Valores quantitativos de taxas de geraçáo de cargas difusas de $\mathrm{N}$ total e $\mathrm{P}$ total foram obtidos através de coeficientes de exportaçáo (Ki), de acordo com classes distintas de uso do solo (Tabela 1) e o mapa. 
TABELA 1 - Valores de coeficientes de exportaçâo (Ki) para estimativa de cargas difusas de acordo com

o uso do solo

\begin{tabular}{lccc}
\hline Uso do solo e cobertura vegetal & Unidade & N total & P total \\
\hline Reflorestamento & $\mathrm{kg} \cdot \mathrm{km}^{2} / \mathrm{dia}$ & 0,600 & 0,039 \\
Urbano & $\mathrm{kg} \cdot \mathrm{km}^{2} / \mathrm{dia}$ & 1,274 & 0,034 \\
vegetação nativa & $\mathrm{kg} \cdot \mathrm{km}^{2} / \mathrm{dia}$ & 0,600 & 0,039 \\
floresta ripária & $\mathrm{kg} \cdot \mathrm{km}^{2} / \mathrm{dia}$ & 0,600 & 0,039 \\
pastagem/campo & $\mathrm{kg} \cdot \mathrm{km}^{2} / \mathrm{dia}$ & 0,500 & 0,028 \\
Agricultura & $\mathrm{kg} \cdot \mathrm{km}^{2} / \mathrm{dia}$ & 2,950 & 0,346 \\
Várzea & $\mathrm{kg} \cdot \mathrm{km}^{2} / \mathrm{dia}$ & ----- & - \\
corpo hídrico & $\mathrm{kg} \cdot \mathrm{km}^{2} / \mathrm{dia}$ & ------ & - \\
\hline
\end{tabular}

Fonte: Dados da pesquisa.

O cálculo da taxa de geração de carga difusa foi baseado na seguinte equação:

$$
\text { Carga difusa }=\Sigma\left(\mathrm{K}_{\mathrm{i}} \times \mathrm{A}_{\mathrm{i}}\right)
$$

Em que: $\mathrm{K}_{\mathrm{i}}$ = coeficiente de exportação de carga difusa de cada parâmetro ambiental para classes distintas de uso do solo; $\mathrm{A}_{\mathrm{i}}=$ áreas distintas de uso de solo na bacia hidrográfica do ribeirão Lobo.

A identificação dos usos do solo produziu um mapa com cenário atual de cobertura composta por oito classes: reflorestamento, urbano, vegetação nativa, mata ciliar (APP), pastagem / campo, agricultura, vegetação de várzea e corpos hídricos (Figura 3). A regiáo norte da bacia é caracterizada por uma grande área de vegetação nativa e uma considerável área de várzea em torno dos corpos de água. Na regiáo oeste existem intensas atividades agrícolas e alguns corpos de água. Na região central há um mosaico de usos do solo e a região oriental é predominantemente destinada ao reflorestamento. A região sul é composta por pastagens, áreas agrícolas e poucas áreas de vegetação nativa remanescente. As áreas de APP da bacia são preservadas, com exceçáo da regiáo sul. 
FIGURA 3 - Mapas de uso e ocupação do solo na bacia hidrográfica do ribeirão do Lobo no cenário atual (2013) e cenários 1, 2 e 3 e respectivas porcentagens de cobertura

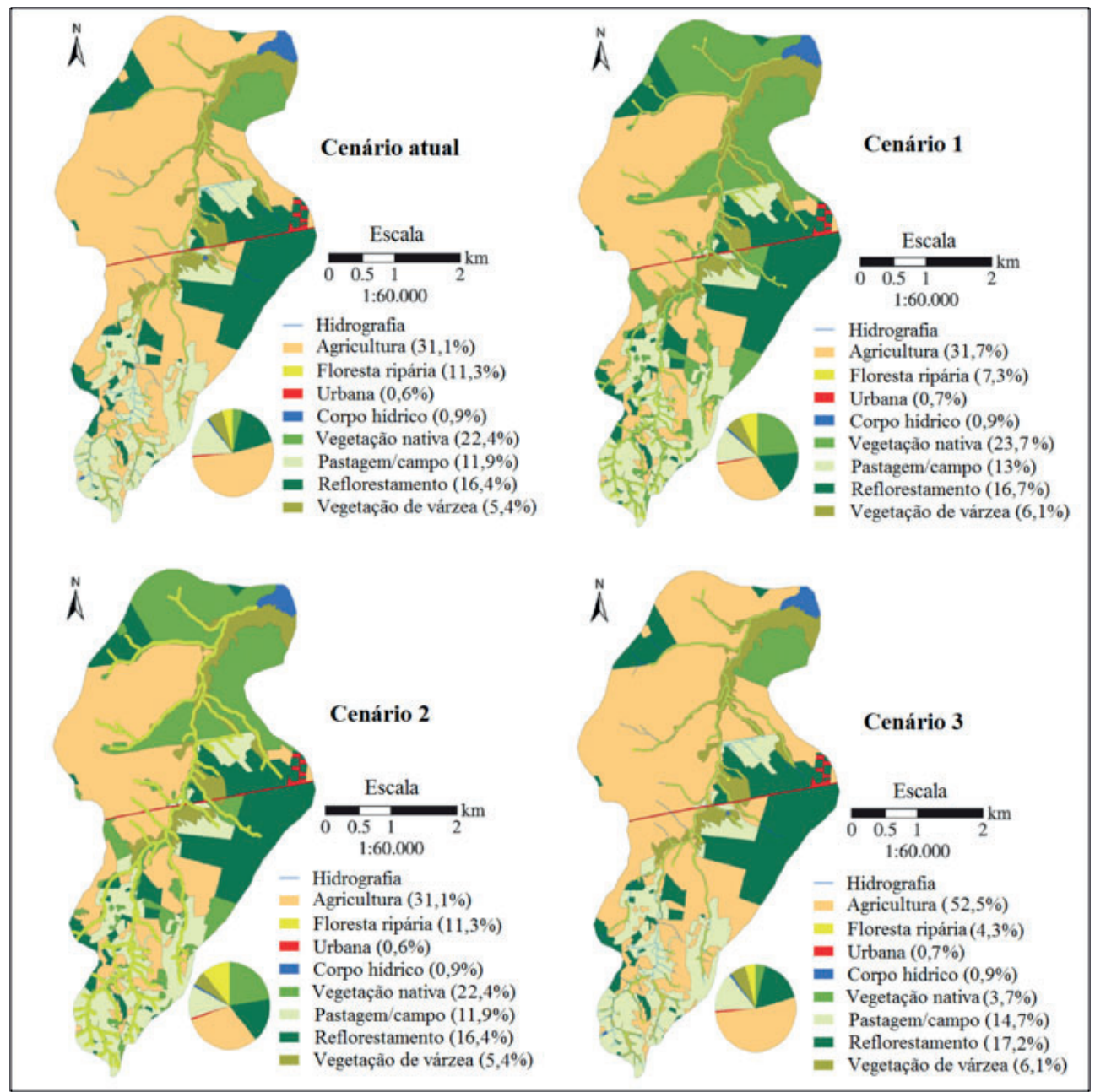

Fonte: Rodrigues-Filho et al. (2015).

Nos mapas gerados no cenário 1 e, especialmente, no cenário 2, houve um incremento das áreas de APP em relação ao cenário atual (em amarelo). Alguns corpos de água, principalmente na região sul, passaram a apresentar áreas de preservaçáo. No cenário 3, por outro lado, a substituição de áreas de vegetação nativa e de floresta ripária por áreas agrícolas resultou em um uso do solo mais uniforme.

Em relação às cargas difusas estimadas, houve pouca alteração entre os valores obtidos para os cenários 1 e 2 e o cenário atual (Figura 4). Por 
outro lado, com a substituição das áreas de vegetação nativa e de floresta ripária por áreas agrícolas, seguindo a premissa do Código Florestal de que não há obrigatoriedade de manter ou recuperar áreas de Reserva Legal em propriedades rurais com áreas inferiores a quatro módulos fiscais, houve um incremento muito significativo das cargas de $\mathrm{N}$ total $(73,6 \%)$ e de $\mathrm{P}$ total $(68,6 \%)$ em relação ao cenário atual.

O estudo mostra, portanto, a grande importância da vegetação nativa e da floresta ripária para a qualidade da água da bacia hidrográfica do ribeirão do Lobo, as quais são capazes de reter fósforo e nitrogênio através da rápida ciclagem biogeoquímica, impedindo o seu transporte para sistemas aquáticos a jusante. Assim, o aumento do desmatamento dessas áreas, conforme evidenciado pelos resultados do cenário 3, resultariam no aumento da eutrofização do ribeirão do Lobo e, como consequência, na eutrofização do reservatório do Lobo/Broa, podendo tornar-se um sério problema, uma vez que o local é um importante polo turístico regional. 
FIGURA 4 - Cargas difusas de Nitrogênio total e Fósforo total, geradas para os diferentes cenários e cobertura do solo na bacia do ribeirão do Lobo
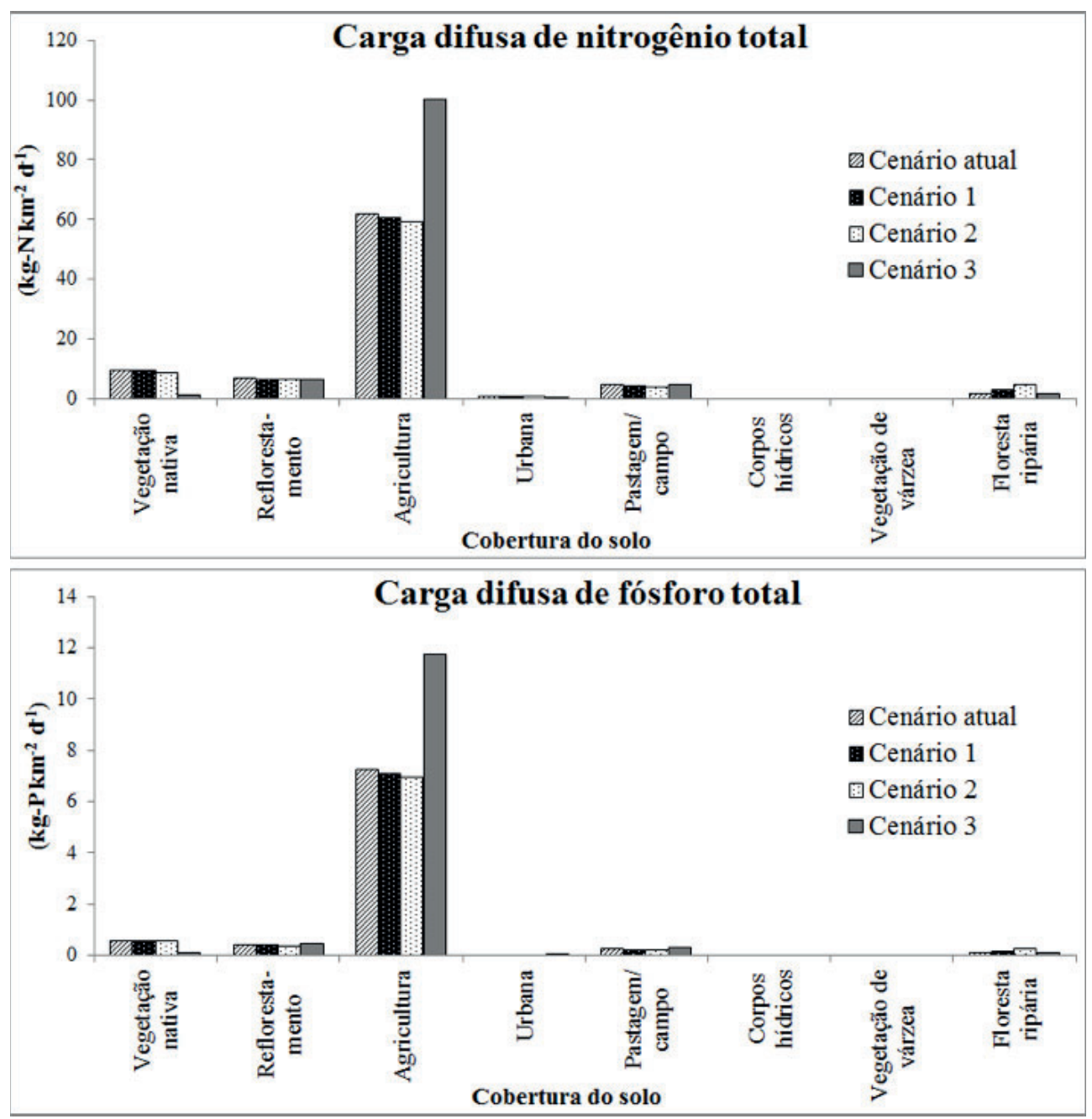

Fonte: adaptado de Rodrigues-Filho et al. (2015). 


\section{Consideraçóes Finais}

Os estudos de caso apresentados no presente capítulo confirmam os importantes serviços ecossistêmicos prestados pelas duas florestas ripárias nas bacias hidrográficas, sobretudo na melhoria da qualidade da água dos corpos hídricos.

Ações que visam a manutenção e a recuperação desses compartimentos, tanto em áreas urbanas como em áreas rurais, devem ser incentivados, uma vez que evitam o processo de eutrofização dos corpos hídricos, contribuem para a estabilidade dos ciclos hidrológicos e biogeoquímicos e dão condições de sustentabilidade aos usos múltiplos da bacia. 


\section{Referências}

BRASIL. Lei 4.771, de 15 de setembro de 1965. Dispóe sobre o Código Florestal Brasileiro. Disponível em: <http://www.planalto.gov.br/ ccivil_03/Leis/L4771.htm>. Acesso em: 24 ago. 2015.

BRASIL. Lei 12.651, de 25 de maio de 2012. Dispóe sobre o Novo Código Florestal Brasileiro. Disponível em: <http://www.planalto.gov.br/ccivil_03/ato2011-2014/2012/lei/l12651.htm>. Acesso em: 14 jun. 2015.

BRASIL. Medida Provisória 2.166-67, de 24 de agosto de 2001. Altera a Lei 4.771, de 15 de setembro de 1965. Disponível em: <http://www. planalto.gov.br/ccivil_03/MPV/2166-67.htm>. Acesso em: 22 ago. 2015.

BRASIL. Resoluçáo CONAMA 303, de 20 de março de 2002. Dispóe sobre os parâmetros, definiçôes e limites das Áreas de Preservação Permanente. Disponível em: <http://www.mma.gov.br/port/conama/res/res02/ res30302.html>. Acesso em: 22 ago. 2015.

CARPENTER, S. R. et al. Nonpoint pollution of surface waters with phosphorus and nitrogen. Ecological Applications, Washington, v. 8, n. 3, p. 559-568, 1998.

LIKENS, G. E. Beyond the shore line: a watershed-ecosystem approach. Verh. Int. Ver. Limnol, v. 22, p. 1-22, 1984.

LIKENS, G. E. The ecosystem approach. Its use and abuse. Excellence in Ecology. Germany: Ecology Institute/Oldendorf-Luhe, 1992. v. 3.

LIKENS, G. E.; BORMANN, F. H. Linkages between terrestrial and aquatic ecosystems. BioScience, v. 24, n. 8, p. 447-56, 1974.

MATTIAZZI, B. Bosques urbanos. Jornal A Folha, São Carlos, 3 out. 2009. Caderno Opiniāo,.MATTIAZZI, B.; FIGUEIREDO, R. A.; KLEFASZ, A. Ecologia, educaçáo ambiental e participaçáo comunitária. Experiência de conservação do patrimônio público Bosques Santa Marta e Cambuí - São Carlos-SP. São Carlos: Rima, 2011.

RODRIGUES-FILHO, J. L. et al. Alterations in land uses based on amendments to the Brazilian Forest Low and their influences on water quality of a watershed. Brazilian Journal of Biology, v. 75, n. 1, p. 125134, 2015. 
SÃO PAULO. SECRETARIA DO MEIO AMBIENTE - SMA. Aplicaçáo do MQUAL 1.5 na gestáo de bacias hidrográficas e avaliação de cargas difusas. Versão 1.5 do modelo de correlação do uso do solo/qualidade da água (MQUAL). São Paulo: SMA, 2003.

SOCIEDADE BRASILEIRA PARA O PROGRESSO DA CIÊNCIA SBPC. O Código Florestal e a ciência: contribuiçóes para o diálogo. São Paulo: Sociedade Brasileira para o Progresso da Ciência/Academia Brasileira de Ciências, 2011.

SHIGAKI, F.; SHARPLEY, A.; PROCHNOW, L. I. Animal-based agriculture, phosphorus management and water quality in Brazil: options for the future. Scientia Agricola, Piracicaba, v. 63, n. 2, p. 194-209, 2006.

TUNDISI, J. G.; MATSUMURA-TUNDISI, T. Impactos potenciais das alterações do Código Florestal nos recursos hídricos. Biota Neotropica, v. 10, n. 4, p. 67-76, 2010.

VOLLENWEIDER, R. A. Scientific fundamentals of eutrophication of lakes and flowing waters, with particular reference to nitrogen and phosphorus as factors in eutrophication. Technical Report n. DAS/ CSI/68.27. Paris: Organization for Economic Co-Operation and Development, 1968. 


\title{
Ecologia da bacia do rio Itanhaém: características limnológicas e uso do solo
}

\author{
Antonio Fernando Monteiro Camargo \\ Leonardo Farage Cancian
}

\section{Introduçáo}

A bacia do rio Itanhaém está localizada na região costeira do Centro-Sul do estado de Sáo Paulo (23 $50^{\prime}$ a $24^{\circ} 15^{\prime}$ S; $46^{\circ} 35^{\prime}$ a $47^{\circ} 00^{\prime}$ ), tem uma área de $944,3 \mathrm{~km}^{2} \mathrm{e}$ é a maior bacia costeira exclusiva do estado (CAMARGO; PEREIRA; PEREIRA, 2002). A bacia do rio Itanhaém tem uma grande diversidade de características naturais e diferentes usos da terra que determinam a ocorrência de rios e riachos com diferentes características limnológicas. Os estudos ecológicos nesta bacia foram iniciados em março de 1990 com o objetivo de caracterizar os diferentes tipos de água. A escolha desta bacia, para se desenvolver estudos ecológicos, baseou-se nas seguintes características: i) as características particulares da região que contém riachos com água branca, preta, clara e salobra, ii) as características de relevo com áreas de planalto, escarpa e planície costeira, iii) as diferenças de uso da terra e iv) a parte superior da bacia, que está localizada em uma área de conservação (Parque Estadual da Serra do Mar). Além disso, também nos motivou a escassez de conhecimento limnológico em ambientes de água doce da regiáo costeira do estado de São Paulo.

Os trechos dos rios localizados na planície costeira são meândricos e têm pequena velocidade de corrente que fornece condiçôes favoráveis ao desenvolvimento de macrófitas aquáticas. Assim, a comunidade de macrófitas tem sido o principal objeto de estudo desde o início do projeto. Paralelamente ao estudo de ecologia de macrófitas aquáticas, nós temos monitorado variáveis abióticas (temperatura, $\mathrm{pH}$, condutividade, turbidez, diferentes formas 
de nitrogênio e fósforo) em intervalos de três meses em aproximadamente 20 locais desde o início dos estudos na região. Os locais de amostragem estáo localizados nos principais rios da bacia: Itanhaém, Preto, Branco, Mambú, Aguapeú, Guaú, Campininha e Castro. A rede hidrográfica da bacia é apresentada na Figura 1.

Inicialmente, os estudos tinham um objetivo descritivo, mas uma nova perspectiva foi adotada e a bacia hidrográfica passou a ser a unidade espacial de estudo em 1994. Esta nova perspectiva foi possível porque nós elaboramos o mapa da rede hidrográfica e os limites da bacia com base em cartas da região produzidas pelo Instituto Brasileiro de Geografia e Estatística (IBGE) no início dos anos 1970. Posteriormente, com base em mapas geológicos da regiáo (SUGUIU; MARTIN, 1978), nós relacionamos as formaçóes geológicas com as características limnológicas de alguns rios. $\mathrm{O}$ produto deste trabalho foi publicado nos Preceendings of the International Association of Theoretical and Applied Limnology (CAMARGO et al., 1997).

FIGURA 1 - Rede hidrográfica da bacia do rio Itanhaém. 1) rio Itanhaém, 2) rio Preto e 3) rio Branco

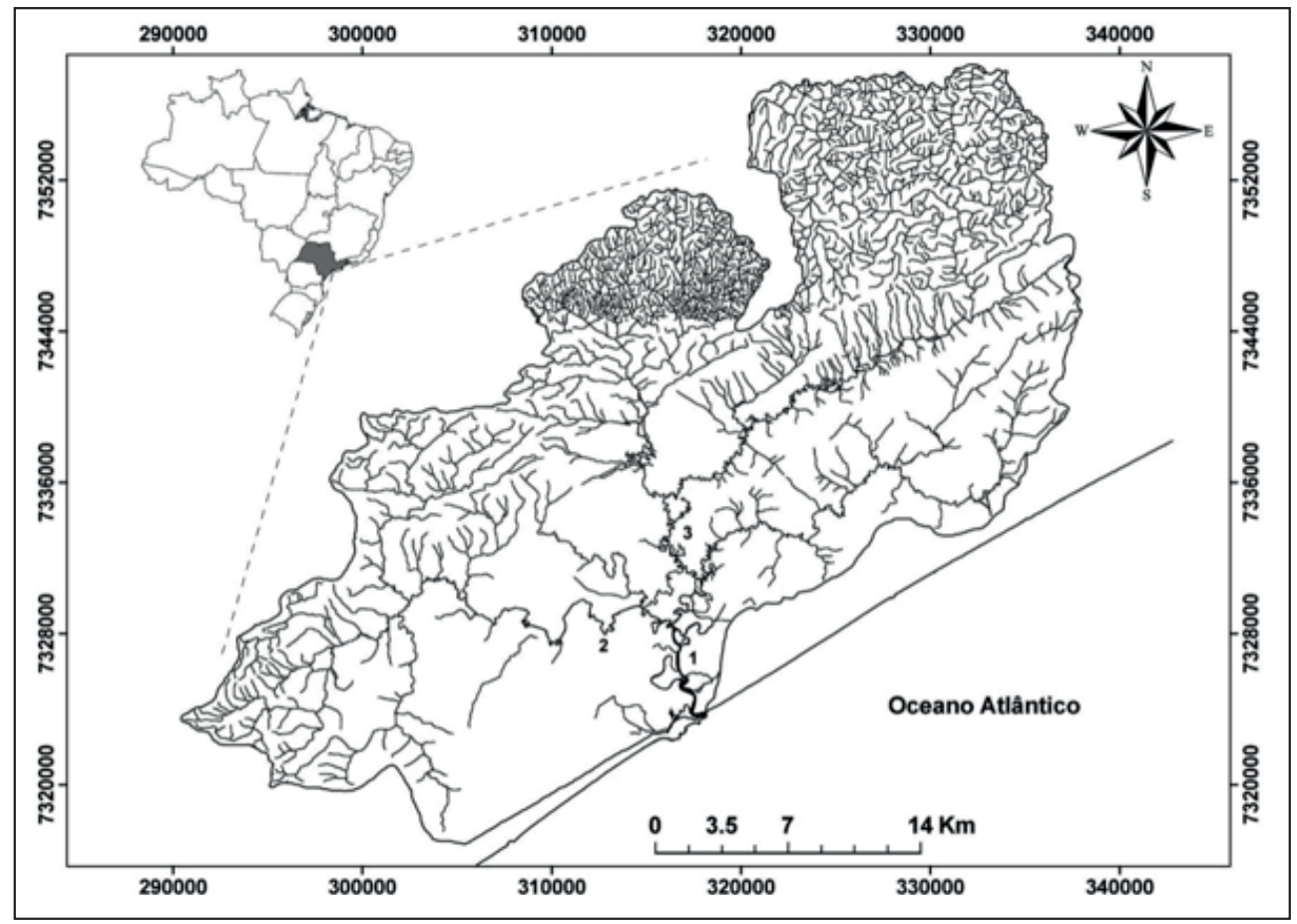

Fonte: CAMARGO et al. (1997).

Elaboração: Leonardo Farage Cancian. 
A partir deste momento, nós passamos a considerar a bacia como a unidade de estudo e iniciamos uma nova abordagem, relacionando as características bióticas e abióticas dos rios com as características dos ambientes terrestres. Este objetivo tem sido possível, pois temos o monitoramento das características limnológicas dos rios e passamos a usar ferramentas de geoprocessamento, como os Sistemas de Informação Geográfica (SIG). A vantagem do uso de SIG é a sua capacidade de relacionar dados físicos, químicos e biológicos com a paisagem.

A relação destes dados é importante para o manejo e ajuda a entender os processos ecológicos na bacia hidrográfica (ASPINALL; PEARSON, 2000; BECKER, 2002). Paralelamente ao uso de SIG, a disponibilidade de imagens de satélite e fotografias aéreas permite relacionar as características dos ambientes aquáticos com as da paisagem. Neste capítulo, nós incluímos informações sobre as características da paisagem da bacia, as características limnológicas dos rios e riachos e também mostramos as interaçôes entre os dois conjuntos de variáveis. Além disso, ao final do capítulo, nós fizemos uma análise crítica da legislação brasileira, que é baseada no conceito de qualidade de água, e uma comparação com a legislação da Comunidade Europeia, baseada no conceito de qualidade ecológica dos ecossistemas aquáticos. As informaçóes que temos sobre a bacia hidrográfica do rio Itanhaém permitem-nos fazer inferências sobre a qualidade ecológica desta bacia.

\section{Características da paisagem}

A bacia tem um relevo com três estratos bem distintos: um estrato constituído pela região de planalto; um outro, compreendendo a planície costeira e; um terceiro, composto pela escarpa. As características destes três estratos são mostradas na Tabela 1. A planície costeira é o estrato com maior área e menor declividade, enquanto a escarpa ocupa a menor área da bacia e maior declividade. O planalto tem a maior variação de declividade com regióes planas e outras regióes nos vales dos riachos com declividade de $90^{\circ}$. 
TABELA 1 - Valores de altitude, área, porcentagem de área e declividade da regiáo de planalto, planície costeira e escarpa da Bacia Hidrográfica do Rio Itanhaém

\begin{tabular}{lllll}
\hline & Altitude $(\mathrm{m})$ & Área $\left(\mathrm{km}^{2}\right)$ & Área $(\%)$ & Declividade $\left(^{\circ}\right)$ \\
\hline Planalto & $680-1020$ & 261,5 & 27,70 & $0,0-90,0$ \\
\hline Planície & $0-100$ & 433,0 & 45,86 & $0,0-4,4$ \\
Costeira & & & & \\
\hline Escarpa & $100-680$ & 249,7 & 26,44 & $17,0-90,0$ \\
\hline
\end{tabular}

Fonte: Dados da pesquisa.

A maioria dos rios tem as nascentes na regiáo de planalto, percorrem a escarpa formando corredeiras e cachoeiras e, quando atingem a planície costeira, passam a ter leitos meândricos e pequena velocidade de corrente. Alguns rios têm a nascente na planície e possuem características particulares porque as nascentes formam pequenas áreas alagadas com pequena velocidade de corrente e são chamadas, regionalmente, de "gamboas". $\mathrm{Na}$ língua Tupi, esta palavra tem o significado de "lugar aonde os rios param, parecendo lagos” (BORDONI, 1990). Estas pequenas áreas alagadas na planície costeira são extensivamente colonizadas por diferentes espécies e formas de vida de macrófitas aquáticas, o que não é comum em rios de pequena ordem.

A bacia tem diferentes formaçóes geológicas e os terrenos Pré-Cambrianos ocupam pouco mais de $50 \%$ da área total da bacia. No entanto, considerando-se as principais sub-bacias, nós pudemos observar características geológicas distintas (Tabela 2). Estas diferentes características geológicas são responsáveis pelos diferentes tipos de água dos rios. Os rios Preto e Aguapeú têm águas pretas, devido à grande porcentagem de área em terrenos do Quaternário, Holoceno e Pleistoceno nas suas bacias, enquanto o rio Mambú tem águas claras porque sua bacia está quase totalmente sobre terrenos Pré-Cambrianos (CAMARGO et al., 1997). As características limnológicas dos rios serão apresentadas na sessão 3 deste capítulo. 
TABELA 2 - Porcentagens de área dos diferentes terrenos geológicos da bacia do rio Itanhaém e das principais sub-bacias

\begin{tabular}{llllll}
\hline Bacia & $\begin{array}{l}\text { Quaternário: } \\
\text { Sedimentos } \\
\text { Continentais }\end{array}$ & $\begin{array}{l}\text { Holoceno: } \\
\text { Sedimentos } \\
\text { de rios, lagos } \\
\text { e baías }\end{array}$ & $\begin{array}{l}\text { Pleistoceno: } \\
\text { Areias de } \\
\text { origem marinha }\end{array}$ & Pré-Cambriano & $\begin{array}{l}\text { Holocene: } \\
\text { Sedimentos } \\
\text { de mangue } \\
\text { e pântano }\end{array}$ \\
\hline Itanhaém & 6,5 & 15,7 & 11,9 & 65,2 & 0,7 \\
Preto & 9,6 & 18,9 & 22,9 & 48,6 & 0,0 \\
Aguapeú & 6,5 & 27,9 & 7,6 & 58,0 & 0,0 \\
Branco & 4,6 & 8,1 & 0,0 & 87,3 & 0,0 \\
Mambu & 5,8 & 2,7 & 0,0 & 91,5 & 0,0 \\
Guau & 0,0 & 17,1 & 74,5 & 0,0 & 8,4 \\
\hline
\end{tabular}

Fonte: Camargo et al. (1997).

A bacia possui um gradiente de formaçóes vegetais naturais. No planal to e escarpa, predomina a Mata Atlântica em condiçóes bem preservadas por estar localizada dentro dos limites do Parque Estadual da Serra do Mar. Na planície costeira, predomina a Mata de Restinga que cobre grandes áreas, embora nesta área também ocorram plantaçóes de banana, pequenos sítios com agricultura de subsistência ou para recreação e a expansão de áreas urbanas que alteram e reduzem a vegetação natural. Na porção inferior da bacia, a vegetaçáo natural é a de mangue, que está circundada pela área urbana e sofre grande pressão antrópica. Existem outras formaçóes vegetais na bacia que ocupam pequenas áreas, tais como campos no planalto e áreas alagadas em torno de alguns rios na planície costeira (Tabela 3).

TABELA 3 - Áreas $\left(\mathrm{km}^{2}\right.$ e porcentagem) das formaçôes vegetais naturais

\begin{tabular}{lll}
\hline Formação Vegetal & Área $\left(\mathrm{km}^{2}\right)$ & Área $(\%)$ \\
\hline Mata Atlântica & 386.06 & 40.63 \\
Restinga & 243.09 & 25.58 \\
Mangue & 4.92 & 0.52 \\
Campos Naturais & 4.78 & 0.50 \\
Áreas alagadas & 5.93 & 0.62 \\
\hline
\end{tabular}

Fonte: Dados da pesquisa.

Em relação ao uso do solo na bacia, foi possível observar diferentes usos e alteraçôes antrópicas. Os principais usos são: i) área de conservação; 
ii) agricultura; iii) vegetação secundária; iv) área urbana com alta densidade demográfica; v) área urbana com baixa densidade demográfica. A área de conservação ocupa pouco mais de $40 \%$ da área total da bacia, está localizada no planalto e escarpa e é coberta pela Mata Atlântica. A maior área ocupada por agricultura é a de sítios de subsistência que se distribui de forma dispersa e fragmentada na bacia. As fazendas de banana estáo localizadas na planície costeira próximas à escarpa, e uma pequena área localizada no planalto é usada para o plantio de eucalipto. Na planície costeira, nós observamos duas pequenas áreas usadas para aquicultura. A bacia também é ocupada pela área urbana do município de Itanhaém na sua parte inferior, próximo à linha de costa. Esta área urbana pode ser dividida em duas partes: uma, com alta densidade populacional, próxima ao centro da cidade; e a outra área com pequena densidade populacional localizada nas partes periféricas. As áreas e porcentagens de área dos diferentes usos do solo podem ser observadas na Tabela 4.

TABELA 4 - Áreas $\left(\mathrm{km}^{2} \mathrm{e} \%\right)$ dos diferentes usos do solo

\begin{tabular}{lll}
\hline Uso da terra & Área $\left(\mathrm{km}^{2}\right)$ & Área $(\%)$ \\
\hline Área protegida & 404,20 & 42,50 \\
Fazendas de banana & 21,38 & 2,25 \\
Eucalipto & 3,16 & 0,33 \\
Aquicultura & 2,48 & 0,26 \\
Sítios de subsistência & 35,53 & 3,74 \\
Total de agricultura & 62,55 & 6,58 \\
Vegetação secundária & 204,45 & 21,52 \\
Área urbana de alta densidade & 26,17 & 2.75 \\
Área urbana de baixa densidade & 12.21 & 1.29 \\
\hline
\end{tabular}

Fonte: Dados da pesquisa.

Nós destacamos que, embora grande parte da área urbana do município esteja inserida na bacia, Itanhaém não possui indústrias. Este município e seus vizinhos, Mongaguá e Peruíbe, têm sua principal atividade econômica baseada no turismo. Devido à presença de praias longas e planas e da proximidade destes municípios da Região Metropolitana de São Paulo (RMSP), muitas pessoas deslocam-se para as cidades praianas nas férias de verão e em feriados. 


\section{Características limnológicas}

As águas dos rios e riachos da bacia possuem características muito distintas devido à diversidade de características da paisagem e do uso do solo. Os rios de águas claras, como o rio Mambú (Figura 3), têm pequenas concentraçōes de nitrogênio total (média $=0,09 \mathrm{mg} . \mathrm{L}^{-1}$ ), fósforo total (média $\left.=22,5 \mu \mathrm{g} . \mathrm{L}^{-1}\right)$, baixos valores de turbidez (10 a $20 \mathrm{NTU}$ ) e de coeficiente de atenuação de luz (média=6,2) e saturação de oxigênio em torno de 100\%.

FIGURA 3 - Vista parcial do rio Mambú próximo da escarpa

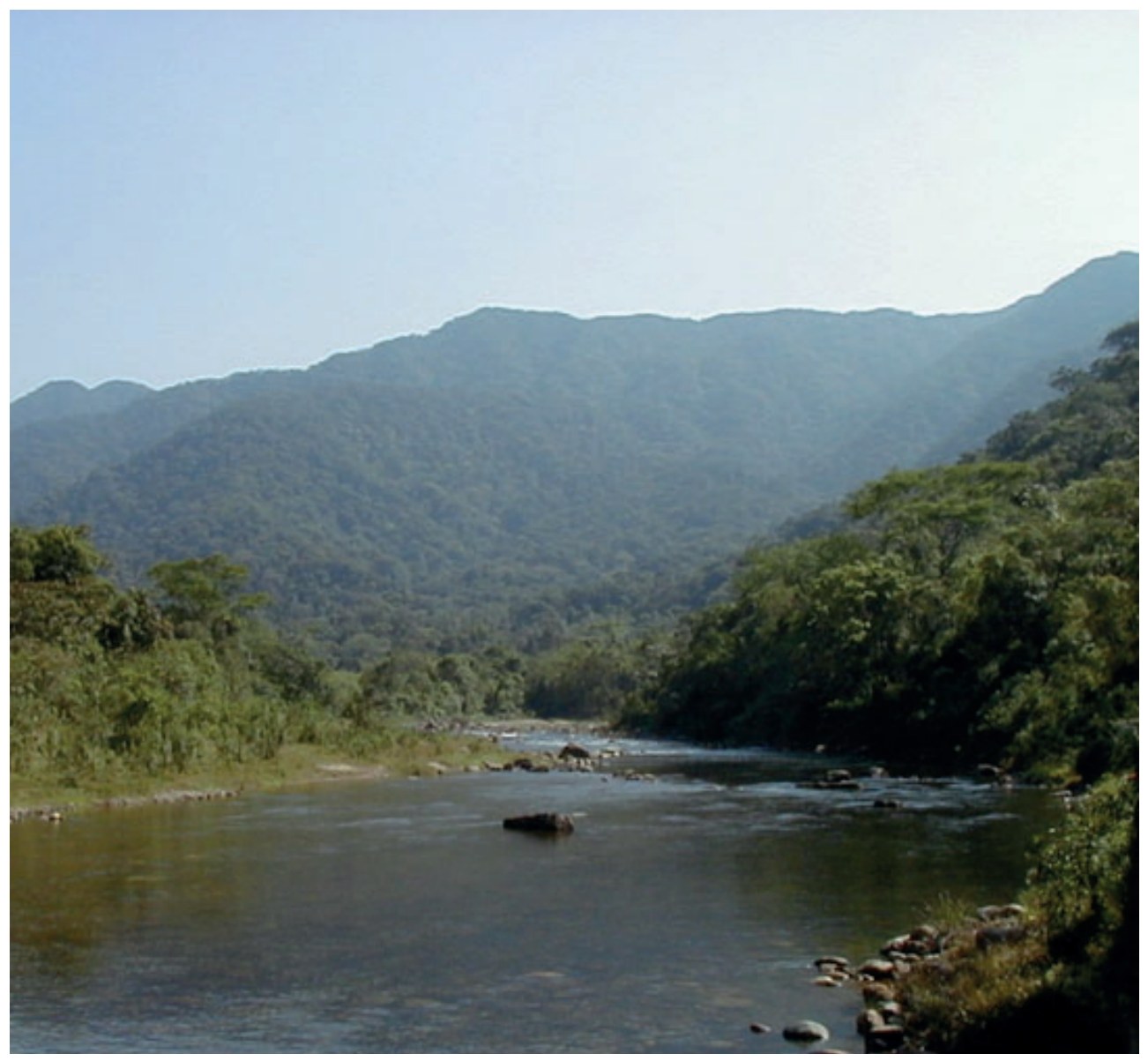

Fotografia: Antonio Fernando Monteiro Camargo.

Fonte: Acervo fotográfico de Antonio Fernando Monteiro Camargo.

Os rios de água preta têm características muito diferentes dos rios de águas claras, pois, visualmente, apresentam uma coloração escura. Isso 
se deve à alta concentração de substâncias húmicas (ácidos húmicos e fúlvidos). Um dos rios que formam o rio Itanhaém é chamado de rio Preto. O rio Castro é um dos principais formadores do rio Preto e tem baixas concentraçôes de nitrogênio total (média $=0,21$ ), fósforo total (média $=31,3$ $\mu \mathrm{g} . \mathrm{L}^{-1}$ ), baixos valores de turbidez (7 a $20 \mathrm{NTU}$ ) e de coeficiente de atenuação de luz (média= 5,7), pH bastante ácido (média=4,5) e saturação de oxigênio em torno de apenas $40 \%$. O rio Aguapeú, também de águas pretas, é tributário do rio Branco. Em algumas ocasiôes, é possível observar o encontro das águas pretas do rio Aguapeú com as águas brancas (barrentas) do rio Branco (figura 4).

FIGURA 4 - Encontro das águas pretas do rio Aguapeú (abaixo) com as águas barrentas do rio Branco (acima)

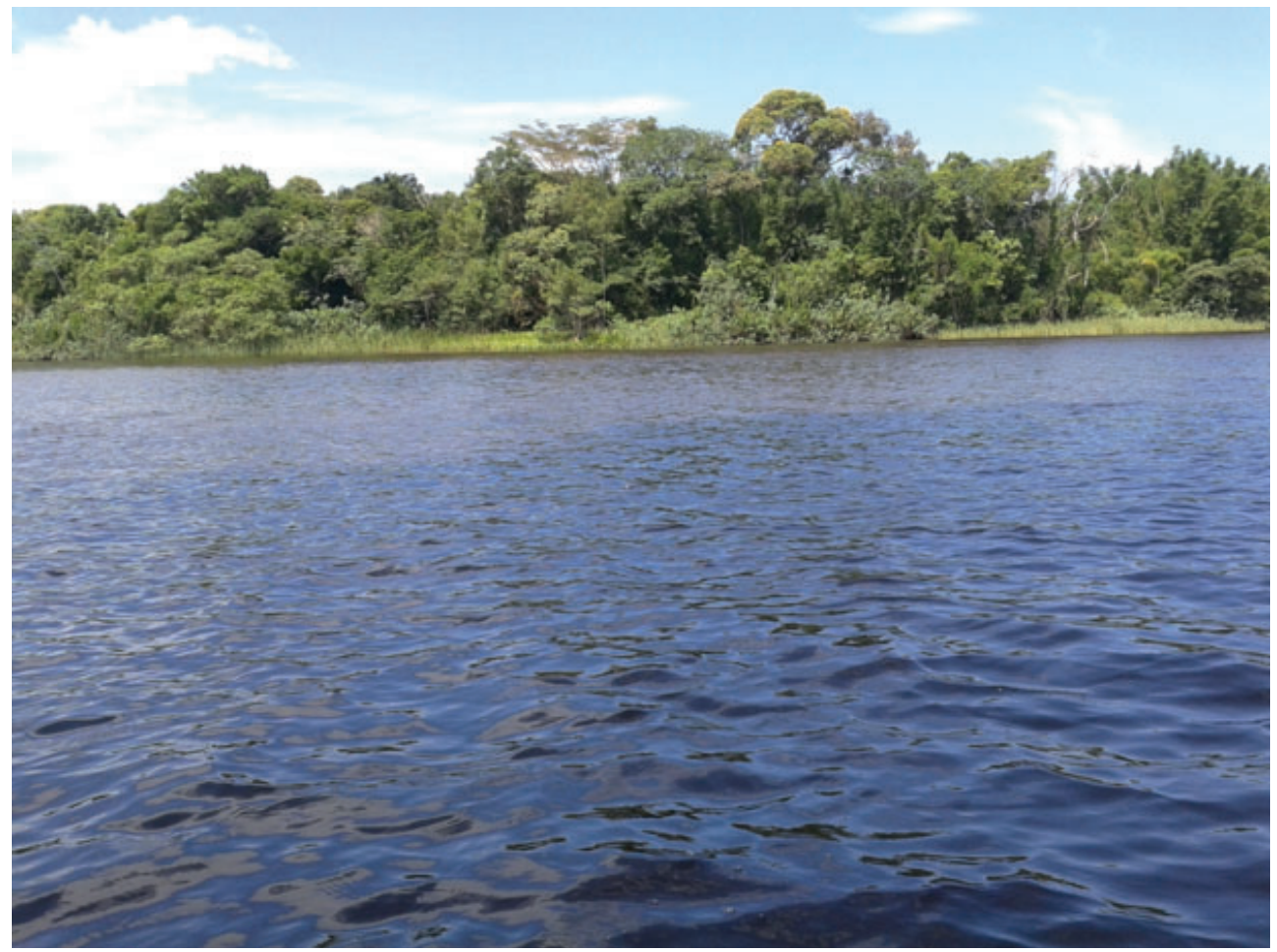

Fotografia: Antonio Fernando Monteiro Camargo.

Fonte: Acervo fotográfico de Antonio Fernando Monteiro Camargo.

O rio Branco é o único representante de águas brancas da bacia. As concentrações médias de nitrogênio total $\left(0,13 \mathrm{mg}\right.$. $\left.\mathrm{L}^{-1}\right)$ e fósforo total $(22,8$ $\left.\mu \mathrm{g} . \mathrm{L}^{-1}\right)$ são ligeiramente maiores do que as das águas claras. Os valores médios de saturação de oxigênio $(71,8 \%)$ são inferiores ao do rio Mambú 
(águas claras) e superiores ao do rio Castro (águas pretas). Os valores médios do $\mathrm{pH}$ da água do rio Branco são ligeiramente ácidos tal como os das águas claras, mas os valores médios de turbidez (45,8 NTU) são duas vezes maiores do que os valores máximos das águas pretas e claras.

O rio Itanhaém é formado pela confluência dos rios Preto e Branco a aproximadamente $6 \mathrm{Km}$ acima da sua foz no oceano e por isso sofre grande influência de águas marinhas. $\mathrm{O}$ regime de marés e a chuva provocam grandes variaçóes temporais nas características limnológicas deste rio. Em períodos de pouca chuva e marés altas, as águas marinhas ocupam 50\% da extensão do rio e, eventualmente, todo o rio Itanhaém contém águas salgadas e salobras. Por outro lado, em períodos muito chuvosos e de marés baixas, nós observamos a presença de água doce a apenas $100 \mathrm{~m}$ da foz. Assim, o rio Itanhaém tem uma intensa dinâmica temporal que é muito pouco previsível. Em alguns períodos, ele tem características de águas marinhas; em outros, águas pretas; e ainda em outras ocasiôes, água salobra. A salinidade da água do rio Itanhaém varia entre 35 (salinidade da água do mar) e zero. $\mathrm{O}$ pH também tem grande variação com valores máximos de 8,0 e mínimos de 6,6. Os maiores valores de turbidez foram observados no verão (50 a $100 \mathrm{NTU}$ ); e os menores, no inverno (30 NTU). Os maiores valores de saturação de oxigênio variam entre 80 e 100\%, enquanto os menores variam em torno de $60 \%$; no entanto, sem um padrão sazonal. As concentraçôes de nitrogênio total (mínimo de 0,1 e máximo de 0,5 mg.L${ }^{1}$ ) e fósforo total (mínimo de 20 e máximo de $82 \mu \mathrm{g} \cdot \mathrm{L}^{-1}$ ) da água do rio Itanhaém têm também grandes variaçóes.

Além destes diferentes tipos de água, que refletem as diferentes características naturais da bacia, existem duas pequenas sub-bacias cujos rios desaguam próximo à foz do Itanhaém e possuem águas com características particulares devido à ação antrópica. Estes rios eram originalmente canais de mangue, mas, atualmente, apenas o trecho final destas sub-bacias (rios Guaú e Campininha) é circundado por vegetação de mangue. Os trechos médios e superiores destas bacias estáo envolvidos pela área urbana, têm os leitos retificados e recebem esgotos domésticos sem tratamento. Estes rios têm altas concentraçóes de nitrogênio e fósforo e, frequentemente, ausência de oxigênio dissolvido. Suas características limnológicas apresentam uma intensa variação temporal em função da variação de marés e de chuvas. Os valores de oxigênio dissolvido no rio Guaú variaram entre $0.4 \mathrm{mg} \cdot \mathrm{L}^{-1}$ (Novembro/1988) e $4.5 \mathrm{mg} \cdot \mathrm{L}^{-1}$ (Fevereiro/1998) e as 
concentrações de fósforo total no rio Campininha variaram de $1132 \mu \mathrm{g}$.L-

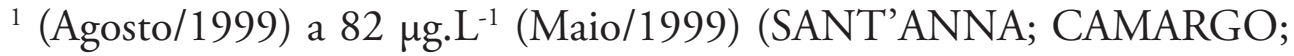
BONOCCHI, 2007).

Macrófitas aquáticas, peixes e zooplâncton são as comunidades bióticas que têm sido estudadas na bacia. Vários estudos sobre ecologia de macrófitas aquáticas têm sido realizados e, neste capítulo, nós destacaremos aqueles relacionados com a distribuição e abundância destes vegetais. A ocorrência e distribuição dos organismos aquáticos na bacia do rio Itanhaém estão relacionadas com as características da água e da paisagem.

As macrófitas aquáticas estão distribuídas na bacia de modo a formarem um gradiente no sentido foz-escarpa. $\mathrm{Na}$ região inferior do estuário, Spartina alterniflora é a única espécie de macrófita presente; e na parte superior deste ocorrem Crinum procerum e Scirpus californicus (CANCIAN, 2012). Na porção intermediária da planície costeira que não é atingida por águas marinhas, existe grande quantidade de várias espécies de diferentes formas de vida, tais como Eichhornia azurea, Pistia stratiotes, Salvinia molesta, Utricularia foliosa, Egeria densa (HENRY-SILVA et al., 2001), dentre muitas outras espécies de Poaceae e Ciperaceae. Na porção superior da planície costeira (transição entre planície e escarpa), ocorrem espécies submersas, tais como Egeria densa, Cabomba furcata e Potamogeton polygonus e Potamogeton pusillus. Este gradiente de distribuição das macrófitas está diretamente relacionado com a influência marinha, declividade da margem, velocidade de corrente, transparência da água, bem como com as concentrações de nitrogênio e fósforo na água (MORI, 2014). A ocorrência das espécies flutuantes livres Pistia stratiotes e Salvinia molesta está relacionada com as concentraçóes de fósforo na água (CAMARGO; BIUDES, 2006). Estes autores observaram que Pistia stratiotes ocorre em locais com concentrações de P-total pouco acima de $100 \mu \mathrm{g}$. $\mathrm{L}^{-1}$, enquanto Salvinia molesta está presente em locais com concentraçóes de P-total entre 53 e $63 \mu \mathrm{g} \cdot \mathrm{L}^{-1}$.

Os locais com maiores concentraçóes de P-total e com a presença de Pistia stratiotes são aqueles sujeitos à descarga de esgotos, enquanto os locais com menores concentraçôes e a presença de Salvinia molesta estáo livres de maiores impactos atrópicos. A biomassa e a composição química de macrófitas são influenciadas pelas características da água e do sedimento que, por sua vez, são influenciadas pelo uso da terra. Spartina alterniflora é uma espécie comum em regióes estuarinas porque possui adaptaçôes para suportar altos valores de salinidade e ocorre na parte inferior da bacia do Itanhaém tanto em locais que têm influência de esgotos (rio Guaú) como 
naqueles sem influência (rio Itanhaém). O rio Guaú tem maiores concentraçóes de nitrogênio e fósforo na água e no sedimento do que o rio Itanhaém, e Spartina alterniflora tem maior biomassa e maiores teores de N e P no rio Guaú (BIUDES; CAMARGO, 2006).

A ausência de proliferaçáo indesejada de macrófitas flutuantes livres na bacia está relacionada a dois fatores: i) a região mais favorável à ocorrência destas espécies é a porção média da bacia, que possui rios com menor velocidade de corrente e água doce, mas que não recebem esgotos urbanos e têm vegetação ripária, e seus canais são relativamente bem preservados; ii) a região que recebe esgotos domésticos não tratados sofre influência de águas marinhas que limitam o crescimento destas espécies. No entanto, nos últimos anos, nós temos observado a proliferação de uma espécie exótica emergente na porção média da bacia. Urochloa arrecta é uma espécie originária da África que expandiu a sua presença nas partes mais baixas dos rios Preto e Branco e em grande extensão do rio Aguapeú. Esta espécie tem um efeito negativo na comunidade de macrófitas aquáticas em Itanhaém porque, nos locais onde ela é dominante, reduz a diversidade de espécies e de formas de vida de espécies nativas (AMORIM et al., 2015).

A distribuição de peixes na bacia ocorre formando um gradiente bem definido, e Ferreira e Petrere (2009) estabeleceram quatro zonas (Fish Zones-FZ) na bacia: i) FZ1, que é formada por peixes estuarinos e que corresponde ao estuário do rio Itanhaém; ii) FZ2, formada por peixes de água doce e que corresponde à planície costeira; iii) FZ3, constituída por peixes de água doce de cabeceiras, que corresponde à área de escarpa e iv) FZ4, que contém peixes de cabeceiras e tem Gymnotus pantherinus como principal espécie e que corresponde à área de planalto. Além destas quatro zonas, os autores também propuseram três zonas de transição (TZs): a primeira, entre FZ1 e FZ2; a segunda, entre FZ2 e FZ3; e a última, entre FZ3 e FZ4. Assim, a influência de águas marinhas e o relevo são os principais fatores responsáveis pelo gradiente de distribuição de peixes na bacia.

A comunidade de copépodos zooplanctônicos da região estuarina do rio Itanhaém também apresenta um gradiente de distribuição de espécies (PEREIRA; CAMARGO, 2004). Na parte inferior do estuário, estes autores observaram espécies adaptadas aos altos valores de salinidade; e na parte superior, espécies de águas doces e oligoalinas. O lançamento de esgotos domésticos em um canal secundário do rio Itanhaém (Volta Deixada) modificou as características da água, aumentando as concentrações de nitrogênio e fósforo, reduzindo 
oxigênio dissolvido e aumentando a densidade de náuplius de copépodos (PEREIRA; CAMARGO, 2004). Tais autores também verificaram intensa dinâmica temporal de características abióticas e da comunidade de copépodos em curtos períodos de tempo em função da variação de marés e sazonais.

Os resultados dos estudos de distribuição de espécies das comunidades de macrófitas aquáticas, peixes e copépodos, associados aos resultados das variáveis abióticas da água e da paisagem, permitem-nos supor que o Conceito do Contínuo Fluvial proposto por Vannote et al. (1980) é o que melhor explica a dinâmica da bacia do rio Itanhaém. No entanto, as características fisiográficas das sub-bacias também determinam diferentes características bióticas e abióticas que promovem descontínuos naturais, ou seja, rios com diferentes tipos de água.

\section{Relação entre as características limnológicas e da paisagem}

As características do relevo, geologia, vegetação e uso do solo são responsáveis pelos diferentes tipos de água da bacia e pelas diferenças observadas nas características limnológicas dos rios. No verão, as características físicas e químicas da água $(\mathrm{pH}$, salinidade, coeficiente de atenuação de luz, oxigênio dissolvido, material em suspensão, carbono orgânico total e diferentes formas de nitrogênio e fósforo) foram significativamente relacionadas com as porcentagens de área dos diferentes terrenos geológicos das sub-bacias e da bacia do Itanhaém como um todo (CAMARGO et al., 1997). Este trabalho mostrou que, na bacia do Itanhaém, existe uma relação direta entre as características limnológicas dos rios e as características geológicas das bacias. Além disso, na porção inferior da bacia (região estuarina), a presença da área urbana influencia diretamente as características da água dos rios, especialmente os rios Guaú e Campininha.

Os rios de água clara estáo localizados no planalto e escarpam locais com a ocorrência de terrenos Pré-Cambrianos. Estes terrenos muito antigos já foram bastante lavados e erodidos nesta região, e o leito dos rios é composto por rochas, pedras, cascalho e areia grossa. Estes riachos são sombreados pela Mata Atlântica, têm grande quantidade de folhas e galhos em decomposição, especialmente nos lugares mais profundos, e constituem a base da cadeia alimentar. Uma fotografia de um desses riachos é mostrada na Figura 5. O rio Mambú é o maior rio da bacia com estas características e, por ser de 
grande pureza, sua água é captada para o abastecimento urbano de algumas cidades localizadas no litoral Centro-Sul do estado de São Paulo.

FIGURA 5 - Riacho da Bacia Hidrográfica do Rio Itanhaém localizado na escarpa

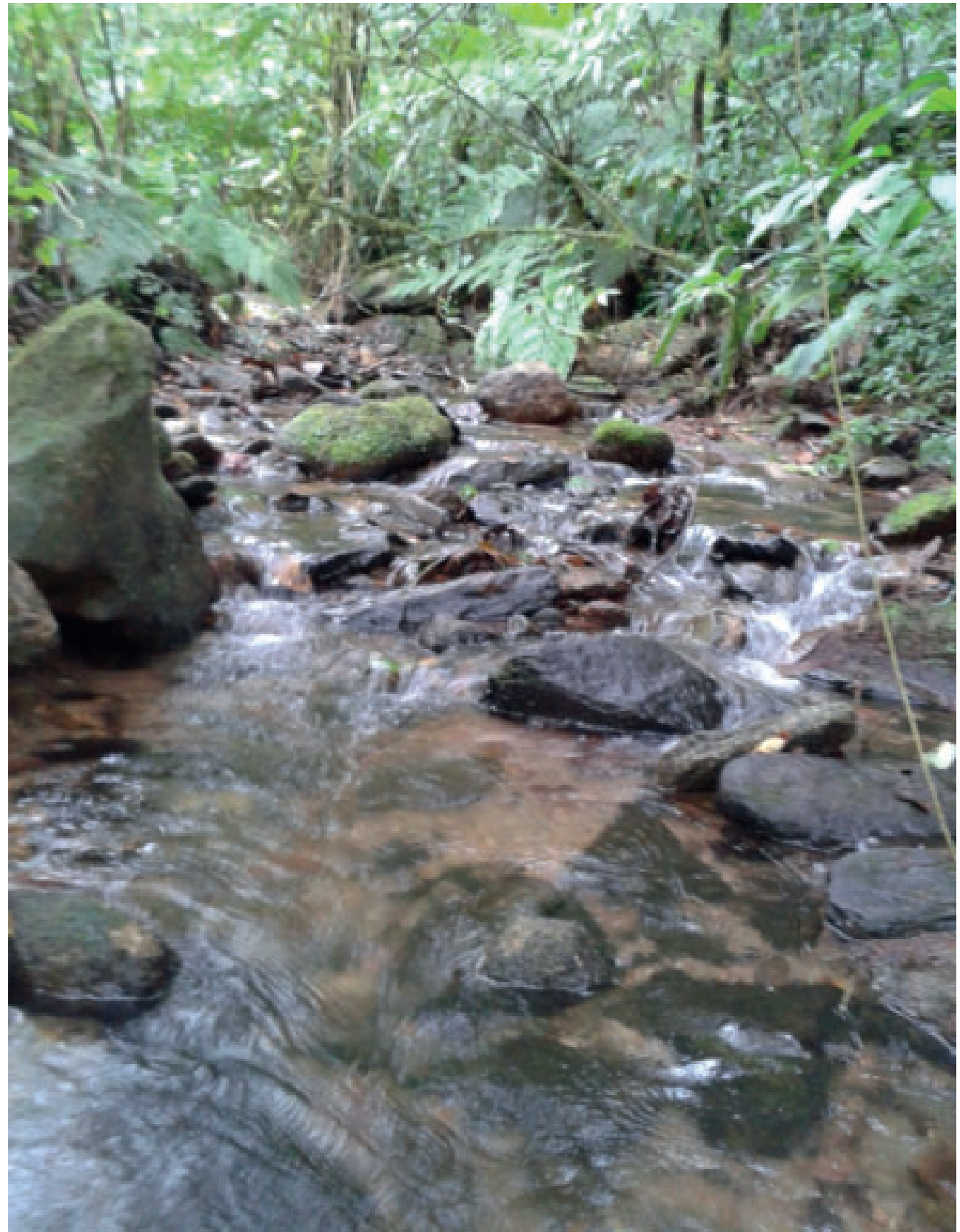

Fotografia: Antonio Fernando Monteiro Camargo.

Fonte: Acervo fotográfico de Antonio Fernando Monteiro Camargo. 
Os rios de águas pretas são aqueles que têm a maior parte de sua bacia sobre terrenos quaternários formados por sedimentos marinhos. Assim, os solos são arenosos e contêm pequenas quantidades de argila, são pobres em nutrientes e têm pouca capacidade de reter umidade. A vegetação terrestre tem adaptações para evitar a perda de água. Por sofrerem constantemente estresse de água, as plantas possuem casca grossa e folhas coriáceas. Celulose, lignina e hemicelulose em decomposiçáo destas estruturas são lixiviadas para os rios devido à pequena quantidade de argila do solo e formam ácidos orgânicos. Assim, as características limnológicas dos rios de águas pretas são um resultado da formação geológica, das características do solo e da vegetação da bacia. A relação com as águas pretas da Amazônia foi bem descrita por Furch (1984). A Figura 6 apresenta um local de amostragens no rio Castro, um córrego da água preta da bacia.

As características da água do rio Branco são consequência da formação geológica da sua bacia hidrográfica. Embora as regióes de escarpa e planalto desta bacia estejam em terrenos Pré-Cambrianos, o rio Branco atravessa grande parte de um vale com terrenos quaternários de origem continental (SUGUIU; MARTIN, 1978). Estes terrenos originam solos relativamente férteis com maior quantidade de matéria orgânica, argila e nutrientes. Estas características do solo influenciam as características limnológicas desse rio. Além disso, grandes plantaçóes de banana estão instaladas no vale do rio Branco . A plantação de banana na região também se dá pelas características do solo mais fértil e de suas encostas mais baixas. Uma vista do vale do rio Branco é apresentada na Figura 7. 
FIGURA 6 - Local de amostragem no rio Castro que tem sua nascente na planície costeira e é um dos formadores do rio Preto

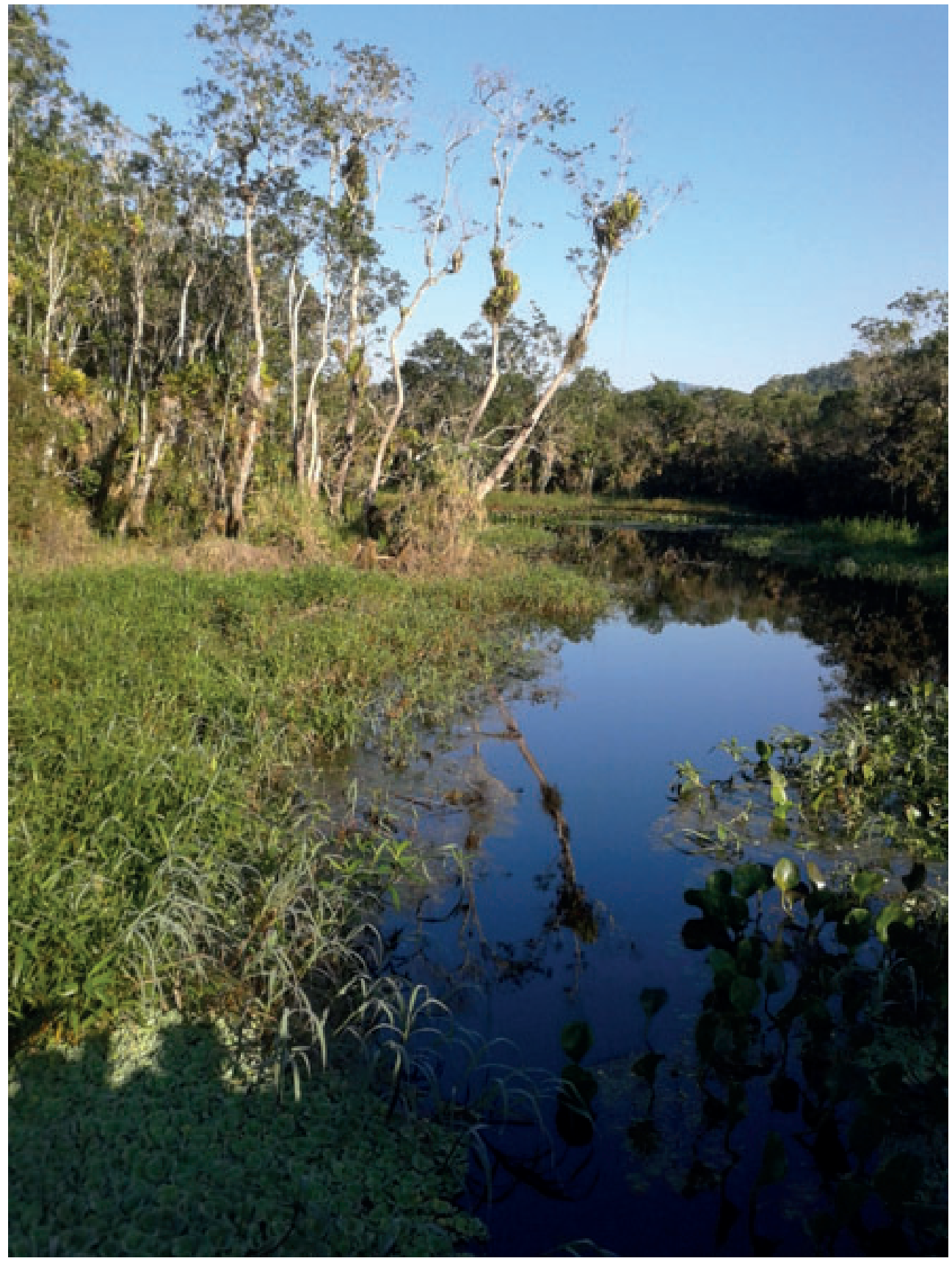

Fotografia: Antonio Fernando Monteiro Camargo.

Fonte: Acervo fotográfico de Antonio Fernando Monteiro Camargo. 
FIGURA 7 - Vista do vale do rio Branco com plantaçôes de banana

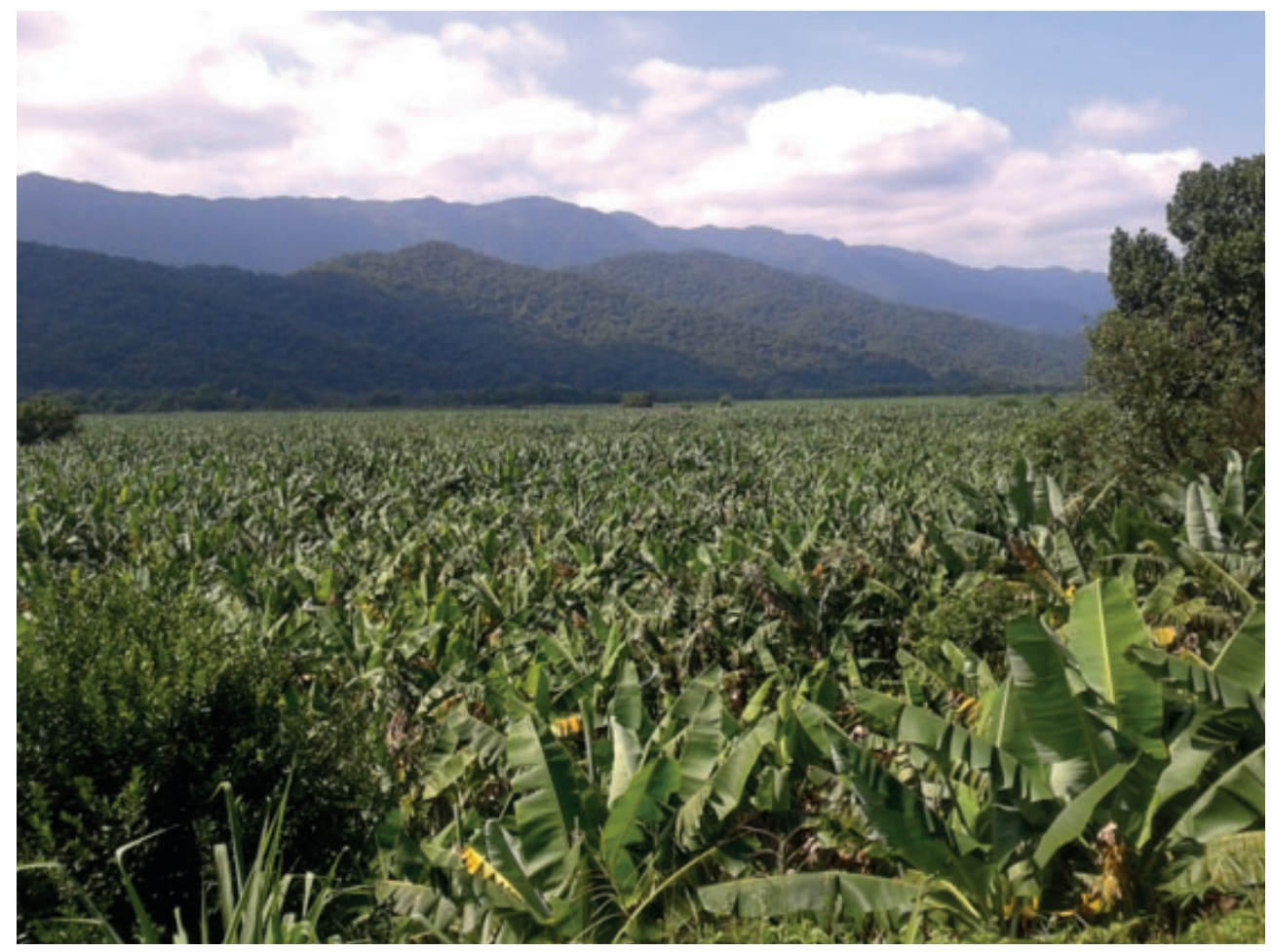

Fotografia: Antonio Fernando Monteiro Camargo.

Fonte: Acervo fotográfico de Antonio Fernando Monteiro Camargo.

O rio Itanhaém tem características muito distintas dos outros rios da bacia porque é o trecho final da bacia hidrográfica e as suas águas são uma mistura de águas pretas, brancas e claras. Além disso, ele recebe as águas marinhas durante os períodos de baixa pluviosidade e marés mais altas. Próximo à sua foz, o rio Itanhaém recebe dois afluentes que estáo rodeados pela área urbana, os rios Guaú e Campininha. Esses dois rios sofrem com o despejo de esgoto urbano náo tratado, e a sua água flui para a regiáo do estuário. No entanto, as características das águas do estuário não indicam a presença de esgoto. As características naturais das águas do estuário são, provavelmente, devido à diluição dos esgotos, tanto pela entrada de água do mar na maré alta como a de água doce das cabeceiras na maré baixa. A área de conservaçáo na Serra do Mar e a baixa densidade populacional na parte média da bacia garantem água com características naturais que promovem a diluição dos esgotos que chegam ao estuário. A Figura 8 mostra uma vista parcial do rio Itanhaém. 
FIGURA 8 - Vista do trecho médio do rio Itanhaém com a Serra do Mar ao fundo

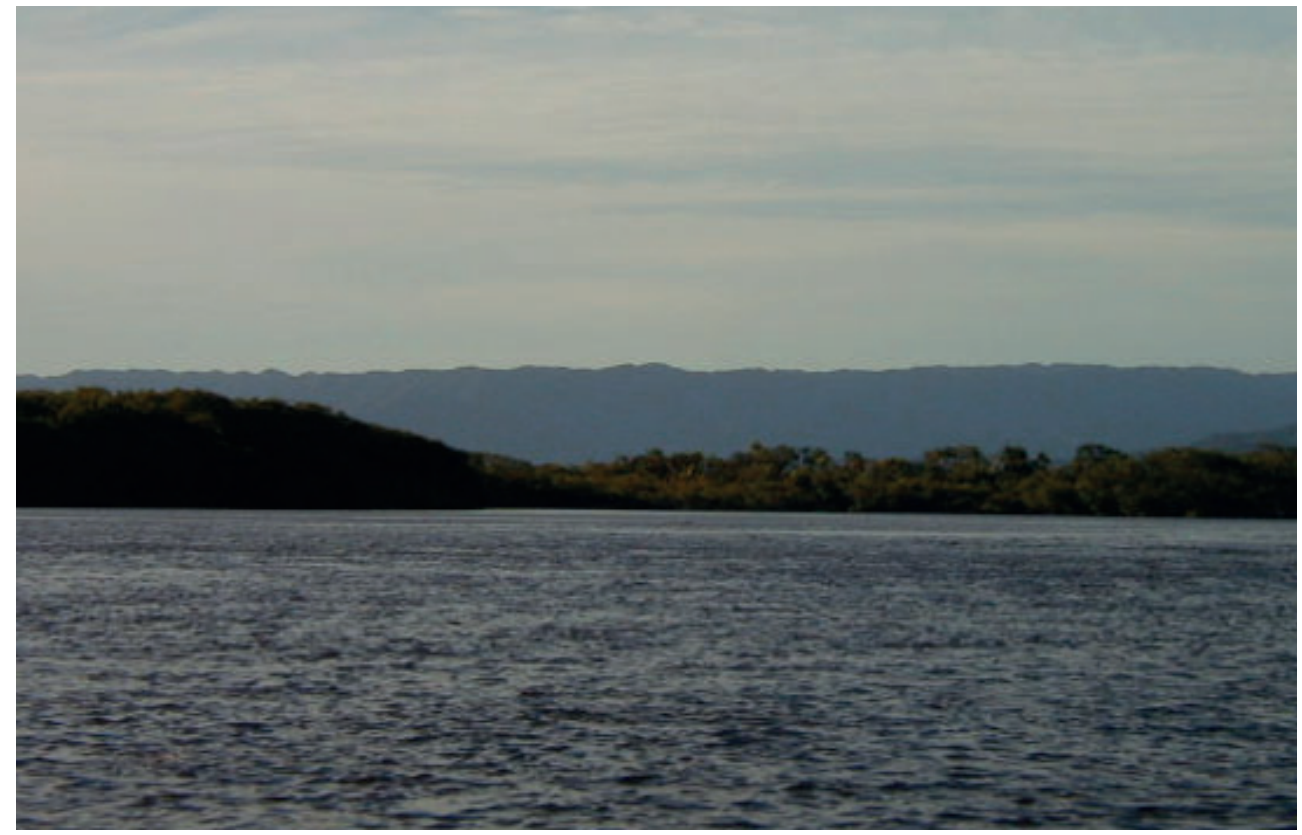

Fotografia: Antonio Fernando Monteiro Camargo.

Fonte: Acervo fotográfico de Antonio Fernando Monteiro Camargo.

\section{Qualidade da água e qualidade ecológica dos rios}

Os termos recursos hídricos e qualidade de água expressam a base conceitual da legislação brasileira quanto aos ambientes aquáticos. A legislação atual, a Resolução no 357, do Conselho Nacional do Meio Ambiente (CONAMA) (BRASIL. Resolução CONAMA 357/2005) estabelece os padróes para o enquadramento dos corpos de água em classes de qualidade. Para as águas doces, existem 5 classes de qualidade (especial, 1, 2, 3 e 4), ordenando a água de mais pura para mais impura. De fato, as classes de qualidade são definidas de acordo com o grau de pureza da água. Assim, os ambientes enquadrados em classe especial são aqueles cujas águas contêm menores teores de material em suspensão, menores concentraçôes de íons, maiores concentraçôes de oxigênio dissolvido, etc. No extremo oposto estão as águas de classe 4, que são aquelas que contêm maiores impurezas. Esta classificação é voltada prioritariamente para o uso da água pelo ser humano.

Por exemplo, segundo a Resolução CONAMA no 357, águas de classe especial são aquelas destinadas ao abastecimento para consumo humano, 
ou seja, aquelas que possuem padrão de potabilidade. Por outro lado, segundo a mesma Resolução, as águas enquadradas em classe 4 são aquelas adequadas para usos menos nobres, ou seja,podem ser usadas apenas para navegação e harmonia paisagística, por exemplo.

Esta Resolução tem várias incoerências, pois considera que águas de classe 4 podem ser utilizadas para harmonia paisagística; e as de classe especial, para a preservação do equilíbrio natural das comunidades aquáticas e dos ambientes aquáticos em unidades de conservação de proteção integral. A Resolução também estabelece que as águas de classe 2 sejam destinadas à proteção das comunidades aquáticas. Entretanto, não necessariamente, os ambientes aquáticos situados em áreas de proteção integral enquadram-se na classe especial, e, embora sejam enquadrados na classe 4, os ambientes altamente poluídos, geralmente, não são paisagisticamente harmoniosos. Além disso, águas com elevado grau de pureza são bastante raras na natureza.

Em ambientes bem preservados, podemos encontrar águas com diferentes graus de pureza e que podem ser enquadradas nas diferentes classes de qualidade, segundo a lei brasileira. A qualidade de água de ambientes aquáticos piora ao receberem efluentes domésticos, industriais, agrícolas, etc. No entanto, as águas naturais possuem as mais variadas características limnológicas, bem definidas pela classificação dos diferentes tipos de água na Amazônia (branca, preta e clara) (SIOLI, 1984), que exemplifica a variabilidade das características limnológicas dos ambientes aquáticos.

As leis brasileiras não incorporam conceitos ecológicos e são frágeis em relação à conservação dos ecossistemas aquáticos. Além da água, utilizamos outros recursos provenientes dos ambientes aquáticos. Os recursos pesqueiros (peixes, crustáceos, moluscos) nos servem como importantes fontes de proteína. A base energética brasileira é baseada na hidroeletricidade. Os rios, os lagos naturais e as represas têm importância como beleza cênica e alimentam a indústria do turismo. Podemos ainda lembrar a importância dos ambientes aquáticos para o transporte e a recreação. Assim, temos que pensar nos usos múltiplos destes sistemas e não apenas na água, sua qualidade e quantidade para uso doméstico, industrial e agrícola.

As leis dos países membros da Comunidade Europeia baseiam-se no conceito de qualidade ecológica dos ecossistemas aquáticos, que estabelece o grau de integridade do ecossistema. Esta diretiva aprovada pelo parlamento europeu em setembro de 2000 tem como inovaçáo que o estado da água passa a ser avaliado através de uma abordagem ecológica, ou seja, 
quanto à conservação do estado natural do ecossistema aquático e não quanto à qualidade da água para uso humano. Para se estabelecer a qualidade ecológica, deve-se levar em conta não apenas as características físicas e químicas da água, mas também as comunidades bióticas (macroinvertebrados bentônicos, peixes, macrófitas aquáticas, fitoplâncton, etc.) e o estado de conservação das bacias hidrográficas através da avaliação do uso do solo.

Outros aspectos importantes da legislação da Comunidade Europeia são a abordagem integrada de proteção das águas (águas de superfície e águas subterrâneas) e o planejamento integrado em nível da bacia hidrográfica. Destacamos que a bacia hidrográfica é a unidade de gerenciamento, avaliação e controle da poluição e dos usos múltiplos dos ecossistemas aquáticos.

Em seguida, faremos o enquadramento de alguns rios da bacia hidrográfica do rio Itanhaém, seguindo o estabelecido pela Resolução CONAMA no 357 (BRASIL. Resolução CONAMA 357/2005).

O ponto de coleta localizado no rio Mambú permite enquadrá-lo na classe 1, segundo a Resolução CONAMA no 357, com base nas variáveis medidas. Os valores de oxigênio são sempre superiores a $6,0 \mathrm{mg} \cdot \mathrm{L}^{-1}$, a turbidez é sempre inferior a 40 NTU e os valores de fósforo e nitrato também estão dentro dos limites da classe 1 definidos pela resolução. $\mathrm{O}$ valor de $\mathrm{pH}$ é de 6,5, ou seja, entre 6 e 9 para enquadramento na classe 1 . Destacamos que, a montante deste ponto de coleta, o rio percorre terrenos do Parque Estadual da Serra do Mar e está, portanto, isento de açóes antrópicas.

Por outro lado, o ponto de coleta localizado no rio Guaú enquadra-se na classe 4 devido aos baixos valores de oxigênio dissolvido, frequentemente zero, e altos valores de fósforo total, que, na maioria das vezes, ultrapassam $100 \mu \mathrm{g} . \mathrm{L}^{-1}$, dentre outras características. Estes valores e o enquadramento estão de acordo com os impactos que este rio recebe. Sua bacia hidrográfica está totalmente urbanizada, com altas densidades demográficas e recebe grande quantidade de esgotos domésticos sem qualquer tratamento.

$\mathrm{O}$ rio Castro, que tem sua bacia relativamente bem preservada, também se enquadra na classe 4 . Esse enquadramento deve-se aos baixos valores de $\mathrm{pH}$ que variam entre 4,0 e 4,7 e também aos valores de oxigênio, que náo ultrapassam 2,0 mg. $\mathrm{L}^{-1}$. Estas características do rio Castro devemse às características naturais do ambiente e não aos impactos antrópicos aos quais está submetido o rio Guaú. Assim, dois rios da bacia do Itanhaém 
enquadram-se na classe de pior qualidade de água, embora um receba fortes impactos e lançamento de esgotos "in natura" e o outro tenha sua bacia bem preservada. Isto demonstra o problema da legislação brasileira, que utiliza o conceito de qualidade de água e náo considera o estado de conservação da bacia hidrográfica.

\section{Comentários Finais}

A bacia do rio Itanhaém é uma excessão quando comparada com outras bacias hidrográficas do estado de São Paulo porque suas características naturais ainda estão relativamente bem preservadas. Esta característica deve-se à grande área da bacia incluída em uma unidade de conservação e à existência de poucas áreas agrícolas e urbanas. Os maiores impactos humanos estáo restritos à parte inferior da bacia e as águas dos rios têm suas características naturais na maior parte desta.

As variáveis físicas, químicas e biológicas da água mostram a existência de um gradiente bem definido no sentido cabeceiras-foz, o que sugere que o Conceito do Contínuo Fluvial é aquele que melhor explica o funcionamento da bacia.

Este capítulo também destaca que a diversidade de ambientes aquáticos não é levada em conta pelos órgãos ambientais brasileiros responsáveis por regular o uso da água, pois estes utilizam apenas algumas características físicas e químicas da água para criar as regras de uso e conservação dos recursos aquáticos. Neste sentido, este capítulo chama a atenção para o fato de que todas as características que compóem um ecossistema aquático - e, consequentemente, o estado ecológico ou a qualidade ecológica do ecossistema - devem ser levadas em consideração para o estabelecimento do uso e de estratégias de conservação destes ambientes. 


\section{Referências}

AMORIM, S. R. et al. Effects of a non-native species of Poaceae on aquatic macrophyte community composition: a comparison with a native species. Journal of Aquatic Plant Management,, v. 53, p. 191-196, 2015.

ASPINALL, R. J.; PEARSON, D. Integrated geographical assessment of environmental condition in water catchments: linking landscape ecology, environmental modeling and GIS. Journal of Environmental Management, v. 59, n.4 p. 299-319, 2000.

BECKER, F. G. Aplicações de sistemas de informação geográfica em ecologia e manejo de bacias hidrográficas. In: SCHIAVETTI, A.; CAMARGO, A. F. M. (Eds.). Conceitos de bacias hidrográficas: teorias e aplicações. Ilhéus, BA: Editus, 2002. p. 91-110.

BIUDES, J. F. V.; CAMARGO, A. F. M. Changes in biomass, chemical composition and nutritive value of Spartina alterniflora due to organic pollution in the Itanhaém river Basin (SP, Brazil). Brazilian Journal of Biology, v. 66, n. 3, p. 781-789, 2006.

BORDONI, O. A língua Tupi na geografia do Brasil. Campinas, SP: Banestado, 1990.

CAMARGO, A. F. M. et al. The influence of the geology on the limnological characteristics of some lotic ecosystems of the Itanhaem River Basin, SP, Brazil. International Association of Theoretical and Applied Limnology, Stuttgart: E Schweizerbart'sche Verlagsbuchhandlung, v. 26, p. 860-864, 1997. Disponível em: <http://hdl.handle.net/11449/20458>. Acesso em: 22 set. 2015.

CAMARGO, A. F. M.; PEREIRA, L. A.; PEREIRA, A. M. M. Ecologia da bacia hidrográfica do rio Itanhaém. In: SCHIAVETTI, A.; CAMARGO, A. F. M. (Eds.). Conceitos de bacias hidrográficas: teoria e aplicaçóes. Ilhéus, BA: Editus, 2002. p. 239-256.

CAMARGO, A. F. M.; BIUDES, J. F. V. Influence of limnological characteriscs of water in the occurence of Salvinia molesta and Pistia stratiotes in rivers from the Itanhaém river basin (SP, Brazil). Acta Limnologica Brasiliensia, v. 18, n.3, p. 239-246, 2006. 
CANCIAN, Leonardo Farage. Modelagem de distribuiçáo geográfica potencial de macrófitas aquáticas em bacias hidrográficas. 2012. $80 \mathrm{f}$. Tese - (doutorado) - Universidade Estadual Paulista, Instituto de Biociências de Rio Claro, 2012. Disponível em: <http://hdl.handle. net/11449/100619>.

FERREIRA, F. C.; PETRERE, J. R. M. The fish zonation of the Itanhaém river basin in the Atlantic Forest of southeast Brazil. Hydrobiologia (The Hague. Print), v. 636, n.1 p. 11-34, 2009.

FURCH, K. Water chemistry of the Amazon basin: The distribution of chemical elements among freshwaters. Monographiae Biologicae, v. 56, p. 167-199, 1984.

HENRY-SILVA, G. G. et al. Chemical composition of five species of aquatic macrophytes from lotic ecosystems of the southern coast of the state of São Paulo (Brazil). Acta Limnologica Brasiliensia, v. 13, n.2 p. 11-17, 2001.

MORI, G. B. Distribuição de macrófitas aquáticas em relação a um gradiente ambiental na bacia do Rio Itanhaém, SP. 2014. 96 f. Dissertação (Mestrado em Biologia Vegetal) - Instututo de Biociências, Universidade Estadual Paulista, Rio Claro, SP, 2014.

PEREIRA, P. E. S.; CAMARGO, A. F. M. Efeito da salinidade e do esgoto orgânico sobre a comunidade zooplanctônica, com ênfase nos copépodes, do estuário do Rio Itanhaém, Estado de São Paulo. Acta Scientiarum, Maringá, PR, v. 26, n. 1, p. 9-17, 2004.

SANT'ANNA, E. B.; CAMARGO, A. F. M.; BONOCCHI, K. S. L. Effects of domestic sewage discharges in the estuarine region of the Itanhaém River basin (SP, Brazil). Acta Limnologica Brasiliensia, v. 19, n. 2, p. 221-232, 2007.

SIOLI, H. The Amazon. Limnology and landscape ecology of a mighty tropical river and its basin. Dordrecht/Boston/Lancaster: Dr. W. Junk Publishers, 1984. Monographiae Biologicae. v. 56.

SUGUIU, K.; MARTIN, L. Carta geológica de Itanhaém. São Paulo: FAPESP, 1978.

VANNOTE, R. L. et al. The river continuum concept. Canadian Journal of Fisheries and Aquatic Sciences, v. 37, n.1, p. 130-137, 1980. 


\title{
Bacia do rio Corumbataí: uso do solo e características limnológicas
}

\author{
Gisele Biem Mori \\ Carla Cristina Cassiano \\ Silvio Frosini de Barros Ferraz \\ Antonio Fernando Monteiro Camargo
}

\section{Introduçáo}

A bacia do rio Corumbataí localiza-se na porção centro-oeste do estado de São Paulo, entre os paralelos $22^{\circ} 04^{\prime} 46^{\prime \prime} \mathrm{S}$ e $22^{\circ} 41^{\prime} 28^{\prime \prime} \mathrm{S}$ e os meridianos $47^{\circ} 26^{\prime} 23^{\prime \prime} \mathrm{W}$ e $47^{\circ} 56^{\prime} 15^{\prime}$ W (Figura 1). Ela é uma sub-bacia da bacia do rio Piracicaba e está situada à margem direita deste rio, representando cerca de 1/6 do território da bacia principal. Segundo o Plano Diretor do Projeto Corumbataí (IPEF, 2002), a bacia do rio Corumbataí possui $1.708 \mathrm{~km}^{2}$, sendo que a maior parte de suas terras encontra-se na Depressão Periférica Paulista. Nela estão inseridos os municípios de Corumbataí, Ipeúna, Rio Claro e Santa Gertrudes; e parte dos municípios de Analândia, Charqueada, Itirapina e Piracicaba. O rio Corumbataí possui sua nascente no município de Analândia e sua foz no município de Piracicaba, sendo seus principais afluentes os rios Cabeça, Passa-Cinco e o ribeirão Claro.

A região apresenta um clima do tipo Cwa (Köppen), ou seja, subtropical, com veróes chuvosos e invernos secos. Mais de $80 \%$ da precipitação anual ocorre no período de outubro a fevereiro e apenas $20 \%$ entre março e setembro. 


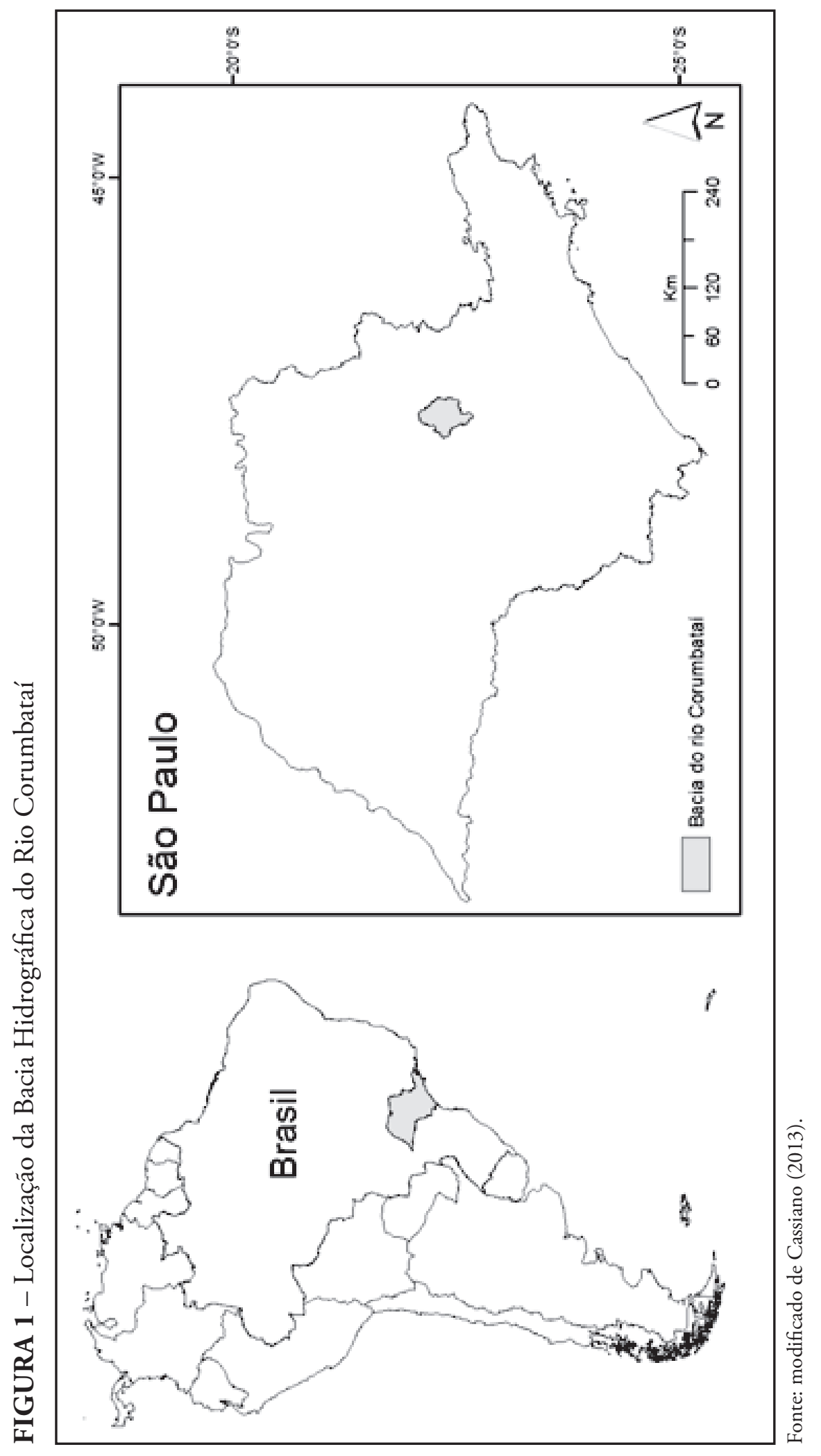


Originalmente, a paisagem da bacia do rio Corumbataí era predominantemente composta por diferentes formaçôes vegetais naturais, como a floresta estacional decidual, floresta estacional semidecidual, florestas ripárias, florestas paludosas e cerrado (RODRIGUES, 1999). O processo de colonização da bacia teve início com a implantação da cultura do café e culturas de subsistência no início do século XX. Estas culturas impulsionaram o desenvolvimento econômico da região, principalmente com a implementação de ferrovias. Posteriormente, as culturas foram substituídas por pastagens e, mais recentemente, tem-se observado a expansão da cultura de cana-de-açúcar (VALENTE; VETTORAZZI, 2005); que apresenta um crescimento contínuo. Segundo Valente e Vettorazzi (2003), a pastagem e o cultivo da cana-de-açúcar ocupam, respectivamente, 43,68\% e $25,57 \%$ da área da bacia (Figura 2).

Atualmente, a bacia do rio Corumbataí situa-se em uma área de elevado desenvolvimento econômico no estado de Sáo Paulo, apresentando um intenso nível de fragmentaçáo da cobertura florestal nativa e uma matriz de uso e cobertura do solo predominantemente agrícola (GRANDE; REZENDE; ROCHA, 2003). Devido ao intenso processo de desmatamento e ocupação desordenada na bacia, a cobertura florestal remanescente ficou restrita a terrenos declivosos e trechos isolados no entorno de corpos d'água. Segundo Valente e Vettorazzi (2005), a bacia encontra-se altamente fragmentada, e os fragmentos florestais remanescentes são pequenos e espalhados pela bacia, de modo que a distância entre os mesmos não favorece sua preservação. A vegetação florestal não apenas na bacia do rio Corumbataí, mas em todo o estado de Sáo Paulo encontra-se altamente degradada, sendo que a maioria dos fragmentos apresenta áreas menores que 50 ha e eles estáo a menos de $100 \mathrm{~m}$ da borda de uns dos outros, tornando-os insuficientes para sustentar a floresta a longo prazo (RIBEIRO et al., 2009). 
FIGURA 2 - Uso do solo na Bacia Hidrográfica do Rio Corumbataí no ano de 2000

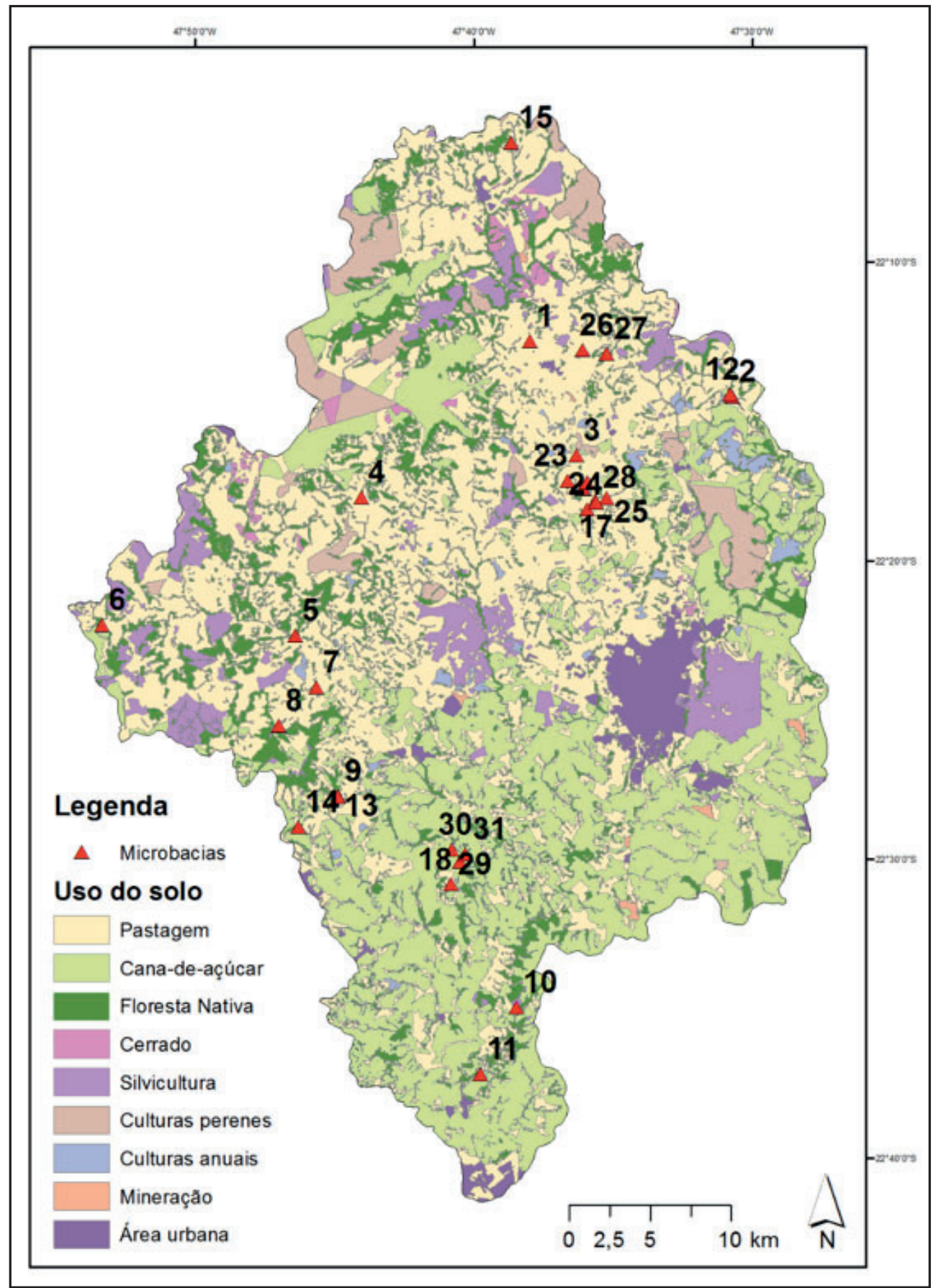

Fonte: modificado de Valente e Vettorazzi (2003). 
No contexto da bacia do rio Corumbataí, o município de Rio Claro é o maior em extensão territorial e densidade populacional (Tabela 1), apresentando grande importância econômica para a regiáo. A atividade industrial do município é concentrada em diversificados estabelecimentos de médio e pequeno porte, como indústrias mecânica, metalúrgica,química, alimentícia, automobilística, de bebidas, confecçóes, calcários, papel, produtos cerâmicos e mineração (IPEF, 2002).

TABELA 1 - Extensão territorial e densidade populacional dos municípios com área urbana na Bacia Hidrográfica do Rio Corumbataí, SP

\begin{tabular}{lll}
\hline \multicolumn{1}{c}{ Município } & Extensáo Territorial $\left.\mathbf{( k m}^{\mathbf{2}}\right)$ & Densidade Populacional $\left(\mathbf{h a b} / \mathbf{k m}^{\mathbf{2}}\right)$ \\
\hline Corumbataí & 278,622 & 3.874 \\
Ipeúna & 190,01 & 6.016 \\
Rio Claro & 498,422 & 186.253 \\
Santa Gertrudes & 98,291 & 21.634 \\
\hline
\end{tabular}

Fonte: IBGE (2010).

Toda a área urbana do município de Rio Claro está localizada na porção média da bacia, entre o ribeirão Claro e o rio Corumbataí; assim, esta é responsável pelos maiores impactos nos rios da bacia. Esta área provoca grande impermeabilização do solo e o lançamento da água de escoamento superficial, contendo resíduos sólidos, óleos e outros produtos de veículos automotores. Além disso, apenas parte do esgoto doméstico é tratado, o que causa grandes impactos nas características limnológicas do ribeirão Claro e rio Corumbataí.

Nos demais municípios, as atividades industriais advêm da extração de minerais, com destaque para a produçáo de cerâmica, principalmente no município de Santa Gertrudes. Rio Claro também destaca-se, dentre esses municípios, quanto ao comércio e prestação de serviços; o que mostra a sua importância na bacia. No setor agrícola, a regiáo possui atividades voltadas à produção de feijão, arroz, algodáo e milho, atendendo à demanda local desses bens. A cana-de-açúcar tem ganhado destaque nos municípios de Analândia, Corumbataí, Santa Gertrudes, Itirapina e Ipeúna, pois a mesma atende à demanda das usinas açucareiras de regióes próximas (IPEF, 2002). Em Rio Claro, a produção agrícola é diversificada; entretanto, a cana-de-açúcar também tem ganhado destaque, ocupando $25 \%$ do total das áreas de lavoura. 
O rio Corumbataí assume importância regional pelo seu potencial hídrico, capaz de abastecer municípios que estão, em sua totalidade, dentro da bacia. Apresenta ainda condiçóes de abastecer municípios que possuem problemas quanto à qualidade de água para captação, como, por exemplo, o município de Piracicaba. Deste modo, a bacia do rio Corumbataí é responsável pelo abastecimento público de aproximadamente 500.000 habitantes (NASSIF, 1998). O município de Piracicaba capta cerca de 90\% da água para abastecimento de sua área urbana do rio Corumbataí; esse, por sua vez, recebe grande parte de esgotos "in natura" da área urbana do município de Rio Claro.

\section{Área rural: uso do solo}

As partes mais altas da bacia, onde se encontram os riachos de pequeno porte e as nascentes dos rios, estão afastadas das áreas urbanas em meio às propriedades rurais. Essas áreas são caracterizadas pela predominância de atividades agrícola e pecuária, principalmente do cultivo da cana-de-açúcar e pastagem. Esses dois usos e as formaçóes vegetais nativas formam os usos do solo predominantes da bacia do rio Corumbataí (VALENTE; VETTORAZZI, 2003).

A pastagem e a cana-de-açúcar estão presentes há bastante tempo na bacia (IPEF, 2002). Com o aumento da produçáo de etanol, o cultivo da cana-de-açúcar tem crescido em todo o estado de São Paulo (RUDORFF et al., 2010) bem como na bacia do rio Corumbataí. O crescimento da cana-de-açúcar vem ocorrendo tanto em áreas onde já era cultivada como também em áreas de pastagem (CASSIANO, 2013); em decorrência disso, a pastagem sofre um processo de redução. As formaçóes vegetais nativas encontram-se praticamente restritas a remanescentes florestais em áreas próximas aos corpos d'água, com uma vegetaçáo degradada ou em algum estágio de regeneração (VALENTE; VETTORAZZI, 2005).

As porcentagens dos três principais usos do solo (pastagem, cana-de-açúcar e floresta) em 31 microbacias (Figura 2) pertencentes à bacia do rio Corumbataí são mostradas na Figura 3. As 15 primeiras (de 1 a 15) estão localizadas nas regióes superiores da bacia. Elas possuem área entre 100 e 600 ha, e o uso do solo foi identificado com base em imagens de satélite do ano de 2000 (MORI, 2010). As outras 16 microbacias (16 a 31) estáo localizadas na área rural da bacia do rio Corumbataí, com áreas entre 10 e 50 ha, e o uso 
do solo destas microbacias foi obtido através de imagens de satélite do ano de 2008 (CASSIANO, 2013). A maioria das microbacias apresenta uma matriz de uso do solo com predominância de pastagem e cana-de-açúcar (Figura 3).

FIGURA 3 - Uso do solo em 31 microbacias da Bacia Hidrográfica do rio Corumbataí

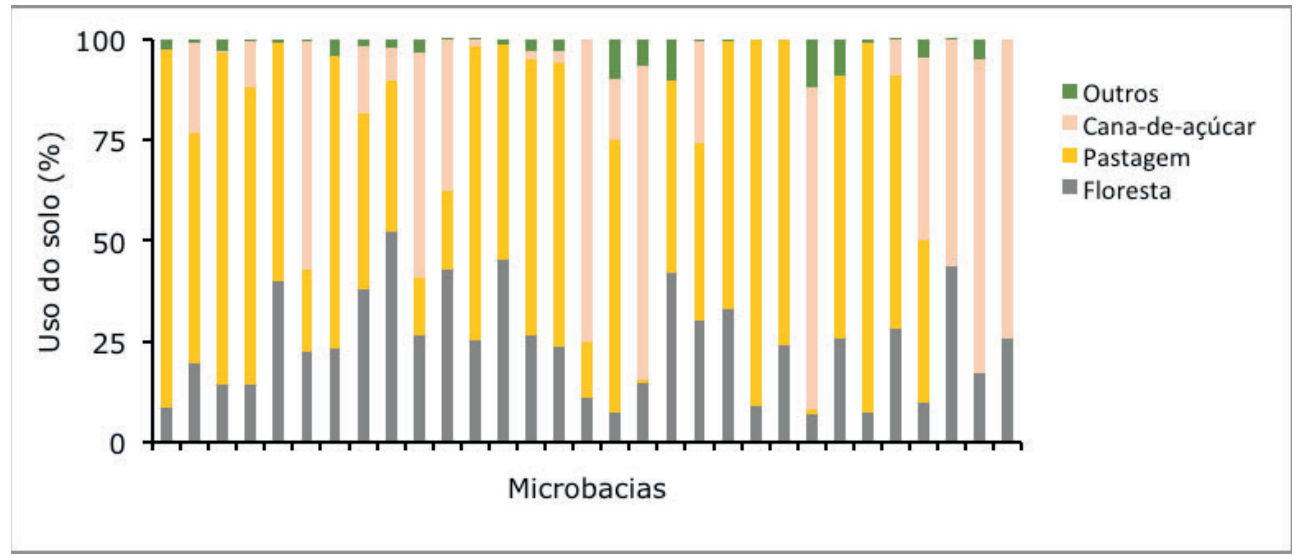

Fonte: Dados da pesquisa.

As porcentagens dos principais usos do solo das 31 microbacias na zona ripária (área de $30 \mathrm{~m}$ ao redor dos corpos d'água) sáo mostradas na Figura 4. Nela, pode-se observar que a floresta representa a cobertura do solo predominante, apesar da pastagem também ser representativa em algumas microbacias. Esses dados confirmam que as florestas estão concentradas nestas áreas.

FIGURA 4 - Uso do solo na zona ripária das 31 microbacias da Bacia Hidrográfica do Rio Corumbataí

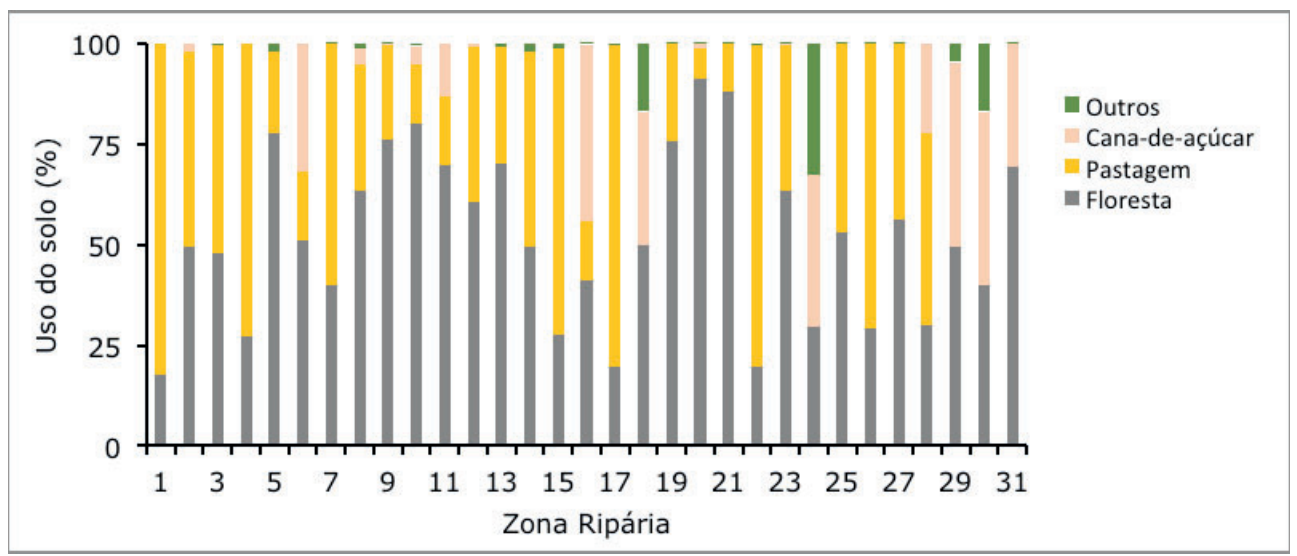

Fonte: Dados da pesquisa. 


\section{Água dos riachos da bacia do rio Corumbataí}

Os riachos da bacia do rio Corumbataí estão localizados dentro das propriedades rurais. Ainda que náo estejam sujeitas aos efluentes urbanos, estas águas sofrem influência da matriz de agricultura; o que pode levar, por exemplo, à entrada de resíduos agrícolas e pesticidas utilizados em cultivos, além do impacto pelo deslocamento do gado pelas áreas de pastagem.

Algumas das variáveis físicas e químicas da água das 15 primeiras microbacias (Figuras 3 e 4), amostradas nas estaçóes seca e chuvosa no ano de 2000, são apresentadas na Tabela 2. As microbacias foram separadas em dois grupos: i) agrícola e ii) misto de agricultura e floresta, considerando o uso do solo com cobertura florestal menor que $40 \%$ e cobertura florestal igual ou maior que $40 \%$, respectivamente. Pode-se observar que a condutividade elétrica, turbidez e sedimento em suspensão são mais elevados nas microbacias do grupo agrícola. Os valores dos nutrientes da água não apresentaram diferenças entre os grupos. Fósforo total é mais elevado na estação seca em ambos os grupos, e nitrato é mais elevado em ambas as estaçóes e grupos.

Algumas variáveis físicas e químicas da água das 16 últimas microbacias (Figuras 3 e 4), amostradas nas estaçóes seca e chuvosa nos anos 2011 e 2012, respectivamente, são apresentadas na Tabela 3. As microbacias foram separadas de acordo com o uso do solo predominante (>40\%) em microbacias com cana-de-açúcar e microbacias com pastagem. 


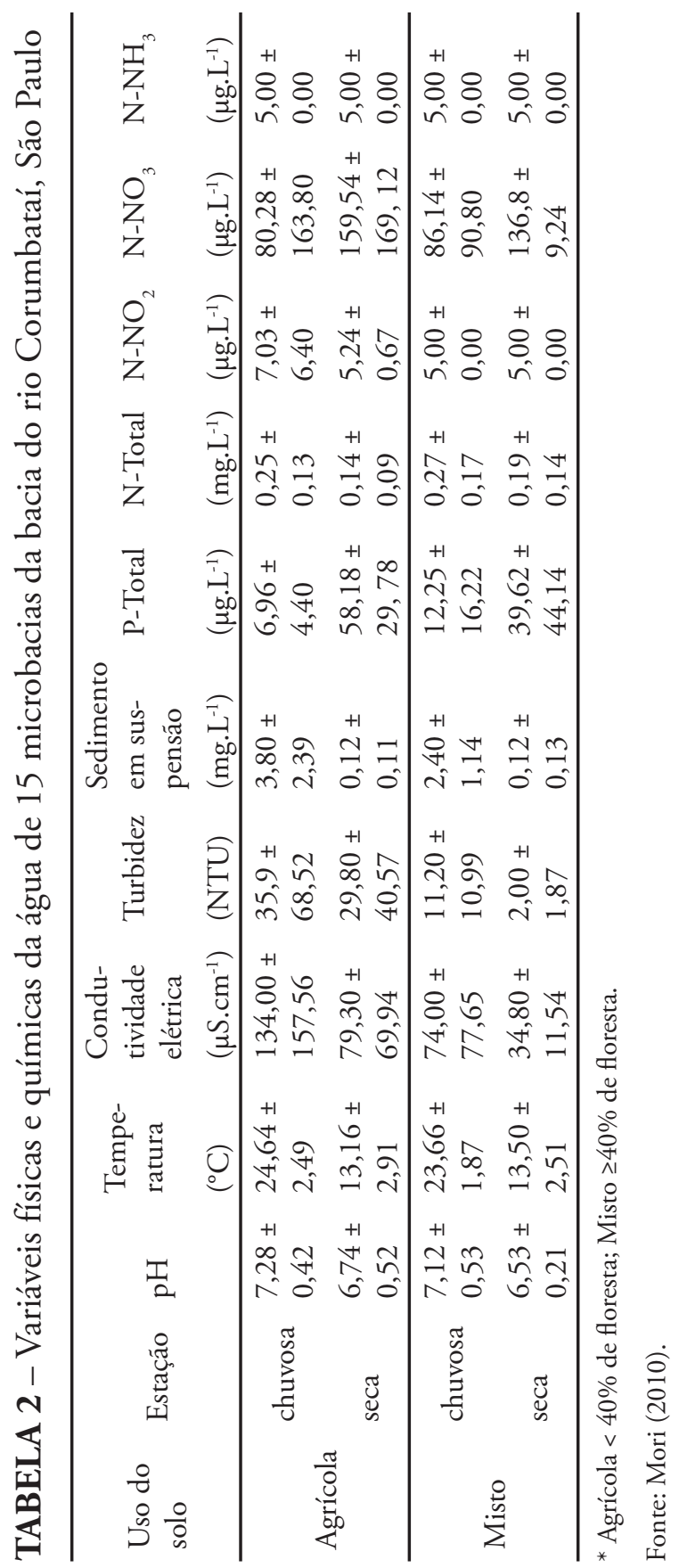




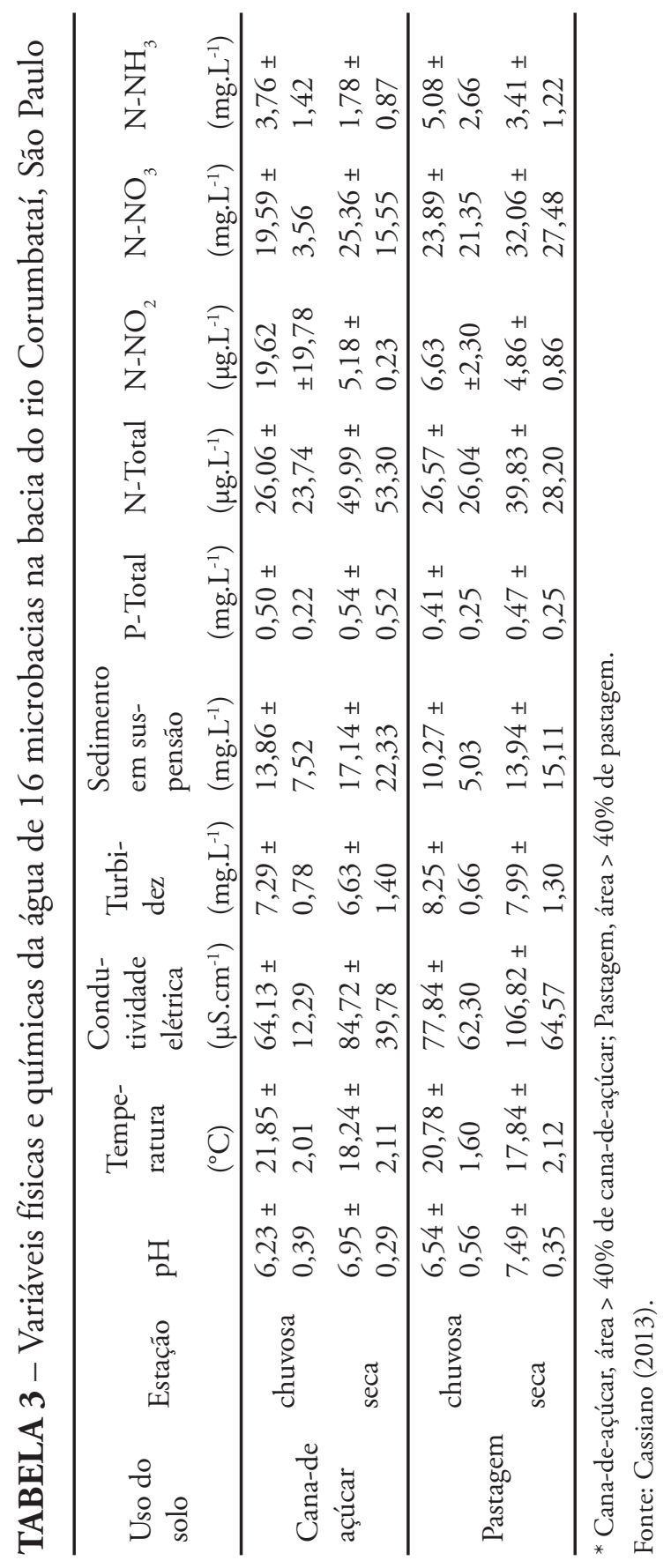


As microbacias com pastagem apresentam valores mais elevados de carbono orgânico dissolvido (DOC) em comparação às microbacias com cana-de-açúcar, que, em contrapartida, apresentam maiores concentraçôes de sedimentos em suspensão em ambas as estaçóes. $\mathrm{Na}$ estação seca, é possível observar altas concentraçóes de nitrato; e na estação chuvosa, altas concentrações de amônia nas microbacias com cana-de-açúcar.

Os maiores valores de condutividade elétrica, turbidez e sedimentos em suspensão nas áreas agrícolas, segundo Mori (2010), mostram o efeito do uso do solo na entrada de sedimentos e íons na água, provavelmente pela diminuição das áreas de floresta (ALLAN; CASTILLO, 2007) e impacto da passagem do gado (COURNANE et al., 2011). O aumento na concentração de sedimentos em suspensão observado por Cassiano (2013) pode ser consequência do movimento do solo ocasionado pelo manejo agrícola. Uma relação positiva entre a quantidade de sedimentos em suspensão em riachos e áreas aradas em bacias hidrográficas foi observada por Naden e Cooper (1999), o que significa que a quantidade de sedimento em suspensão relaciona-se diretamente com as áreas agrícolas (AHEARN et al., 2005).

As concentrações de DOC possuem uma variação considerada normal em riachos, com valores entre 1 e 5 mg. L $^{-1}$ (HAUER; LAMBERTI, 2006); entretanto, na estação chuvosa, é possível observar valores mais elevados nas microbacias com predominância de pastagem, como os encontrados no estudo de Cassiano (2013). No período de chuvas, os nutrientes presentes no solo são carregados para os corpos d'água e a serapilheira da floresta é uma fonte importante de DOC (SCHWENDENMANN; VELDKAMP, 2005). A presença de gramíneas nos riachos também leva a um aumento na carga orgânica (NEILL et al., 2006). Além disso, a entrada de matéria orgânica de dejetos animais está relacionada ao escoamento superficial (BIGGS; DUNNE; MURAOKA, 2006).

Os trabalhos de Mori (2010) e Cassiano (2013) evidenciaram as altas concentraçôes de nitrato em áreas agrícolas em geral e em áreas com cultivo de cana-de-açúcar nas microbacias do rio Corumbataí. A cultura de cana-de-açúcar é uma cultura anual que necessita de uma alta demanda de nitrogênio (KRUSCHE et al., 2003), e a aplicação de fertilizantes nitrogenados pode aumentar a mineralizaçáo e as taxas de nitrificação, aumentando a concentração de nitrogênio nos corpos d'água (SILVA et al., 2007), especialmente no período seco. De fato, as microbacias agrícolas 
da bacia do rio Corumbataí são compostas por uma mistura de cultivo de cana-de-açúcar e pastagem; assim, as altas concentraçóes de nitrato observadas devem ocorrer devido ao uso de fertilizantes que sáo carreados para os corpos d'água (HUNTER; WALTON, 2008).

Os valores reduzidos de amônia podem ser uma consequência da alta capacidade de remoção e transformação de nitrogênio inorgânico nas nascentes. A amônia é assimilada rapidamente, o que provoca a sua pequena concentração nas águas (PERTENSON et al., 2001). No entanto, o aumento das concentraçóes de amônia na estação chuvosa nas áreas de cana-de-açúcar podem ser uma consequência do uso de fertilizantes nos cultivos sem tempo suficiente de ser assimilado de fertilizantes nos cultivos e sem tempo suficiente de ser assimilado.

\section{Área urbana}

Toda a área urbana do município de Rio Claro está localizada na região central da bacia do rio Corumbataí e é a maior área urbana inserida na bacia. De acordo com o Departamento de Água e Esgotos (DAAE) do município, 99,3\% da população tem seu esgoto captado, mas apenas $30 \%$ deste esgoto é tratado (RIO CLARO. DAEE, 2015); ou seja, grande parte do esgoto é lançado sem nenhum tratamento nos corpos d'água da bacia. A maior parte do esgoto urbano é lançada no córrego da Servidáo, riacho que cruza a área central na zona urbana e é um dos afluentes do rio Corumbataí. O rio Corumbataí recebe pouca quantidade de efluentes, e o ribeirão Claro recebeu grande quantidade de efluentes sem tratamento até muito recentemente. Após 2011, os efluentes lançados no ribeirão Claro passaram a ser tratados pela estaçáo de tratamento Conduta.

A água para abastecimento urbano é retirada do rio Corumbataí e do ribeirão Claro, a montante da área urbana. Nos últimos três anos, foram monitorados seis pontos localizados a montante e a jusante da área urbana de Rio Claro no final da estaçáo seca (final de agosto). Este período foi escolhido para monitoramento, pois é a época em que o fluxo dos rios está menor e ocorre uma menor diluição dos efluentes. De fato, Daniel et al. (2002) observaram em um estudo em pontos poluídos, localizados nas proximidades da bacia do rio Corumbataí (município de Piracicaba), os menores valores de oxigênio e os maiores valores de condutividade elétrica e carbono orgânico e inorgânico nos meses de estiagem. 
O primeiro ponto de amostragem do monitoramento está localizado no ribeirão Claro, a montante da área urbana e próximo a um local de captação de água para abastecimento urbano (ponto1). O segundo ponto amostral está localizado no rio Corumbataí, também a montante da área urbana e próximo a outro ponto de captaçáo de água (ponto 2). O ponto 3 está localizado no trecho médio do córrego da Servidão, a jusante dos pontos de despejo de esgoto. O ponto 4 está localizado no ribeirão Claro, àa jusante da área urbana e após o lançamento de esgoto tratado pela estação de tratamento Conduta. O quinto ponto de coleta está localizado no rio Corumbataí em um ponto após do qual recebe as águas do córrego da Servidão e do ribeirão Claro. O último ponto de monitoramento está localizado no rio Corumbataí, próximo à foz do rio Piracicaba, a montante da área urbana de Piracicaba e próximo à captação de água para abastecimento deste município. As localizaçóes dos pontos são apresentadas na Figura 5. 
FIGURA 5 - Localização dos pontos amostrais na Bacia Hidrográfica do Rio Corumbataí

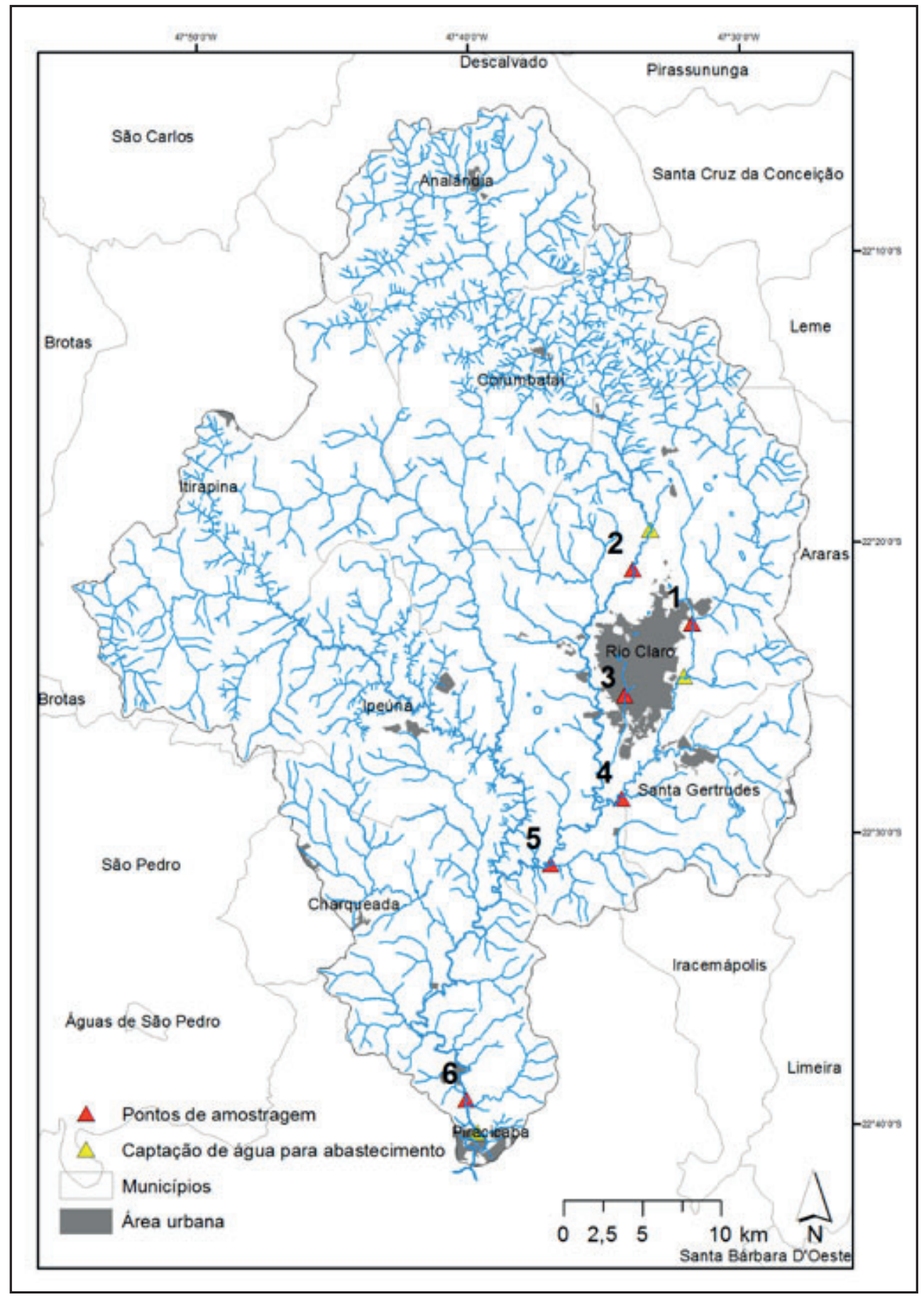

Fonte: elaborado pelos autores. 
Os valores de algumas variáveis físicas e químicas das águas são apresentados nas Figuras 6 e 7, nas quais observa-se grandes diferenças entre os pontos de coleta.

FIGURA 6 - Valores médios e desvio padrão (barras) dos valores de oxigênio dissolvido, condutividade elétrica, turbidez, alcalinidade, ortofosfatos e fósforo total nos seis pontos de coleta na bacia do rio Corumbataí
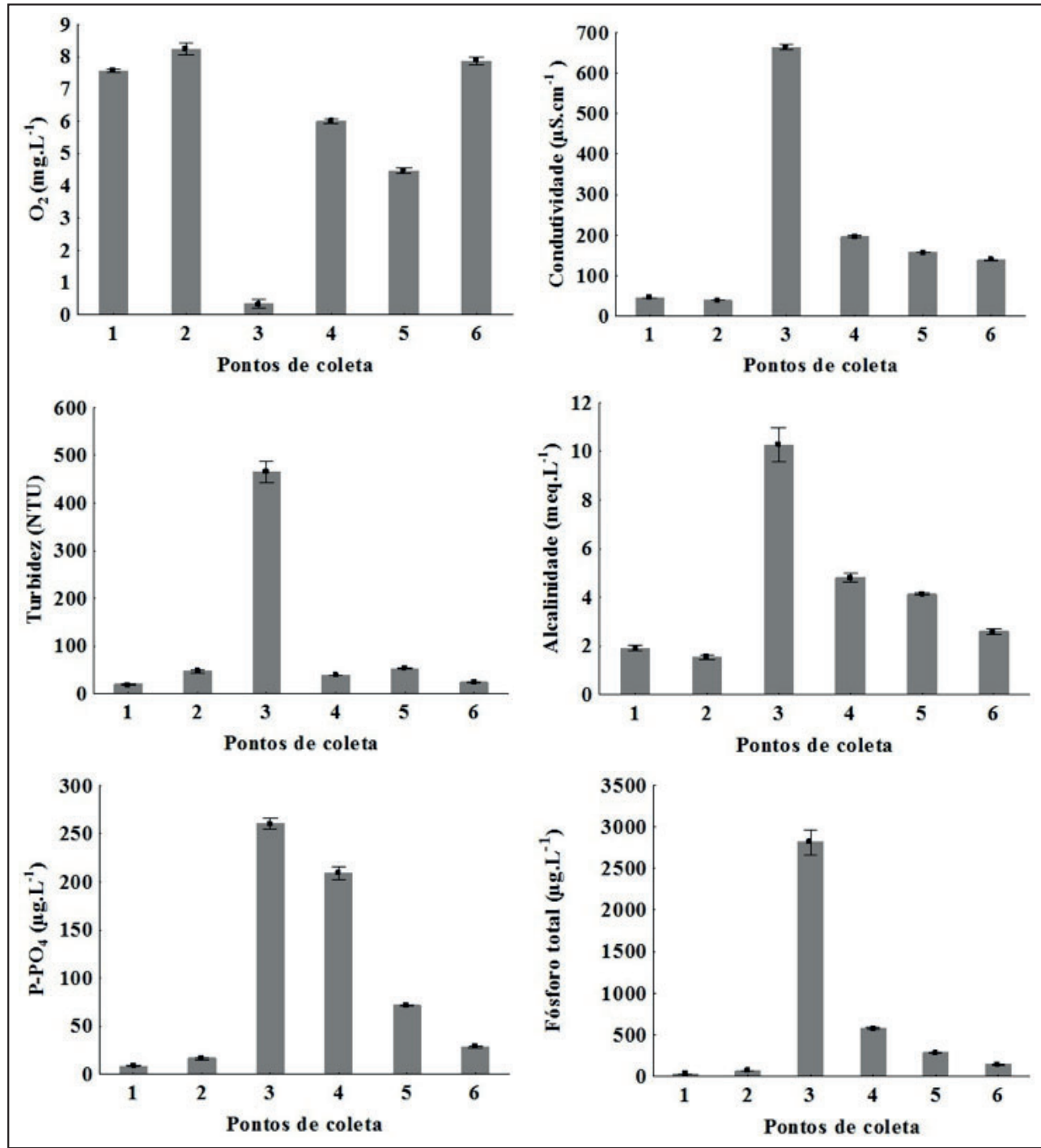

Fonte: Dados da pesquisa. 
Os pontos 1 e 2, localizados a montante da área urbana de Rio Claro, apresentam altas concentraçóes de oxigênio e valores reduzidos de condutividade elétrica, alcalinidade e turbidez. As concentraçóes das diferentes formas de nitrogênio e fósforo também são reduzidas, indicando a ausência de fontes de poluição orgânica. Por outro lado, o ponto 3 possui características limnológicas que mostram altos níveis de poluição orgânica. De fato, a concentração de oxigênio é próxima a zero, e a condutividade elétrica, alcalinidade e turbidez são altas. Os valores de oxigênio dissolvido abaixo de $2,0 \mathrm{mg}$. $\mathrm{L}^{-1} \mathrm{e}$ condutividade elétrica com valores entre 400 e $600 \mu \mathrm{S} . \mathrm{cm}^{-1}$ foram observadas por Daniel et al. (2002) em riachos poluídos na área urbana do município de Piracicaba.

FIGURA 7 - Valores de nitrito, nitrato, nitrogênio amoniacal e nitrogênio total nos seis pontos de coleta na Bacia Hidrográfica do Rio Corumbataí

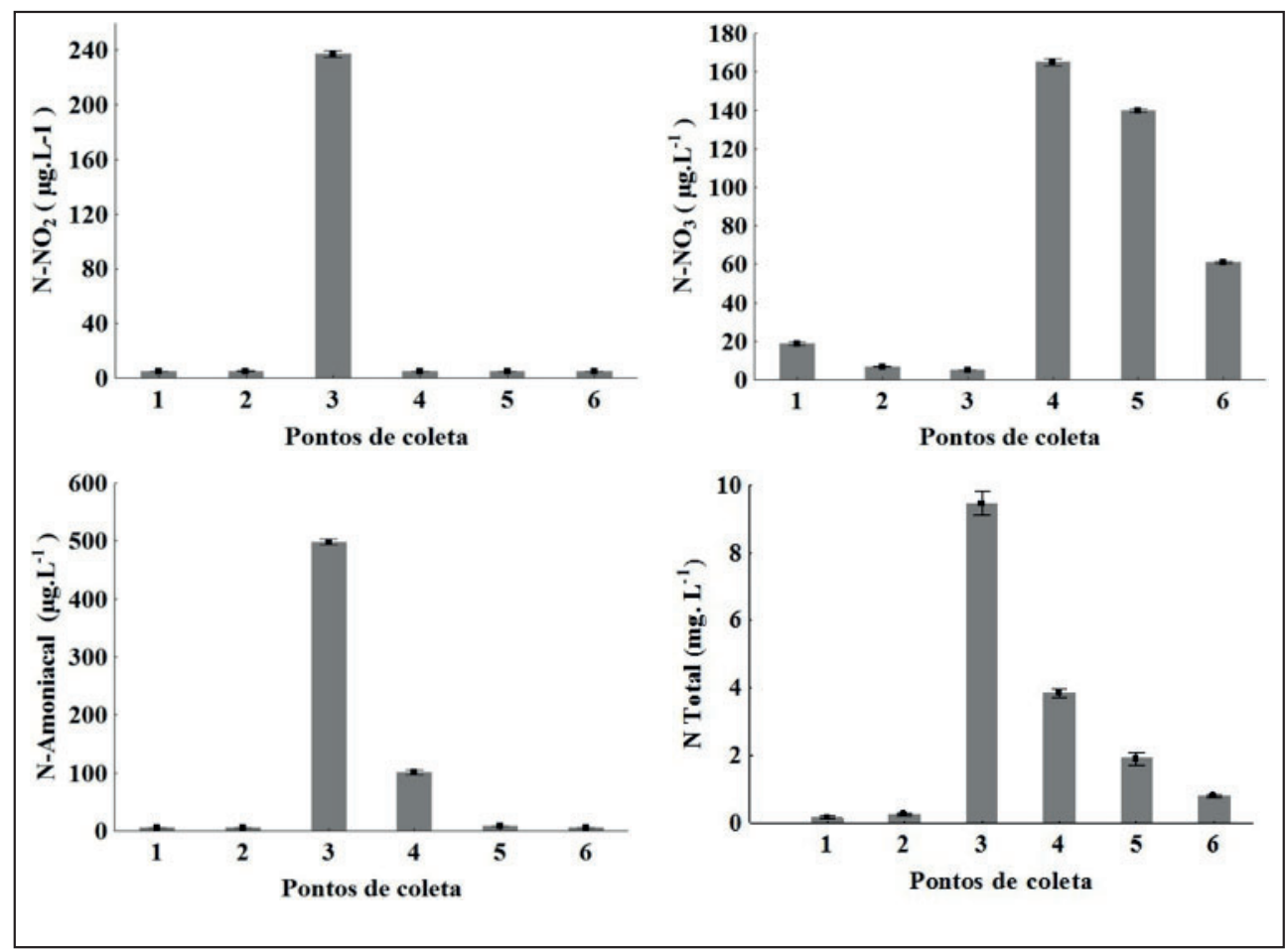

Fonte: Dados da pesquisa.

As concentraçôes de fósforo no ponto 3 são bastante elevadas e destaca-se o valor de 3,0 mg. $\mathrm{L}^{-1}$ para fósforo total. As concentraçóes das diferentes 
formas de nitrogênio tamém são elevadas, exceto para o nitrato, devido ao baixo valor de oxigênio (Figuras 6 e 7). Ambientes aquáticos com condiçóes redutoras (baixo teor de oxigênio) favorecem os processos de amonificaçáo, e as concentraçóes de nitrogênio inorgânico são acumuladas na forma de amônia (ESTEVES; AMADO, 2011). Rios localizados no município de Manaus (Amazonas, Brasil) foram estudados por Couceiro et al. (2007). Estes autores obtiveram valores máximos de condutividade elétrica da água de $662,3 \mu \mathrm{S} . \mathrm{cm}^{-1}$, P-total de 411,37 $\mu \mathrm{g} . \mathrm{L}^{-1}$ e N-total de 2,388 mg.L $\mathrm{L}^{-1}$. Além disso, os mesmos autores observaram valores de oxigênio dissolvido de apenas $0,80 \mathrm{mg} . \mathrm{L}^{-1}$. Estes valores foram similares aos encontrados por Daniel et al. (2002) e em nossas avaliaçôes, evidenciando que, independente da regiáo geográfica, rios que recebem grande quantidade de efluentes de esgoto urbano têm características físicas e químicas da água similares.

Os valores de algumas variáveis medidas no ponto 4 indicam que a água possui boa qualidade. As concentraçôes de oxigênio são elevadas $(6,0$ mg. $\mathrm{L}^{-1}$ ) e a turbidez é relativamente reduzida (Figura 6). Entretanto, os valores de fósforo total e, principalmente, ortofosfato, nitrogênio total e nitrato são muito elevados. Estas altas concentraçóes indicam que o tratamento realizado pela estação Conduta não é eficiente para remover os nutrientes e/ou o lançamento dos efluentes sem tratamento. No rio Piracicamirim (município de Piracicaba), Daniel et al. (2002) observaram que, após a implementação do tratamento de esgoto, as concentraçóes de carbono inorgânico reduziram, mas a condutividade elétrica permaneceu elevada. Estes autores concluíram que valores elevados de condutividade elétrica indicam altas concentraçóes de íons como ortofosfato e nitrato, como observado no ponto 4. De fato, as estaçôes de tratamento construídas no Brasil atualmente possuem apenas tratamento primário e secundário que removem o material orgânico, mas apenas pequenas quantidades de nutrientes. Para a remoção dos nutrientes é necessário empregar o tratamento terciário (GUPTA et al., 2012).

Os pontos amostrais localizados no rio Corumbataí, a jusante da área urbana de Rio Claro (Pontos 5 e 6), possuem características limnológicas que indicam uma melhora na qualidade da água. Os valores de oxigênio são mais elevados e as concentraçóes de $\mathrm{N}$-total e P-total mostram uma redução gradual. Estes resultados indicam que o processo de autodepuração está ocorrendo neste trecho do rio. Um fator importante para a melhora na qualidade da água é o processo de diluição do esgoto do rio Corumbataí pela água da bacia do rio Passa-Cinco, composta por estee pelo rio Cabeça. 
Ambos os rios drenam uma regiáo da bacia que possui apenas o município de Ipeúna, que agrega uma população de 6.016 habitantes. Assim, a água destes rios possui quantidades reduzidas de matéria orgânica em comparação com as águas do rio Corumbataí, promovendo uma diluição do esgoto urbano de Rio Claro. Entretanto, é importante destacar que o ponto 6, localizado próximo ao ponto de captação de água para abastecimento de Piracicaba, tem a qualidade da água inferior ao da água retirada para abastecimento de Rio Claro. Os valores de ortofosfato, P-total e N-total neste ponto são maiores do que nos pontos 1 e 2 (Figuras 6 e 7).

\section{Consideraçóes Finais}

A bacia do rio Corumbataí é predominantemente coberta por agricultura (cana-de-açúcar e pastagem) e possui apenas pequenos fragmentos de floresta nativa. A atividade agrícola ocasiona alteraçôes nas características limnológicas dos rios: na estaçáo seca, ocorrem maiores concentraçóes de carbono orgânico dissolvido em locais com pastagem, de sedimentos em suspensão e de nitrato; na estação chuvosa, há elevada concentração de amônia em locais com cana-de-açúcar.

A presença da área urbana de Rio Claro e o lançamento de esgoto sem tratamento causam grande impacto nos corpos d'água da região e alteram as características limnológicas do rio Corumbataí após a sua passagem pela área urbana. O início do tratamento do esgoto no município de Rio Claro foi responsável pela melhora na qualidade da água do ribeirão Claro.

Como há um investimento na expansão da remoção do esgoto e previsão de tratamento de todo o esgoto produzido pela área urbana de Rio Claro, espera-se que a qualidade da água dos corpos d'água apresente uma melhora. Entretanto, consideramos que é necessária a restauraçáo da vegetação nativa nas áreas agrícolas, especialmente na floresta ripária, para reduzir o impacto do cultivo da cana-de-açúcar e pastagens nos corpos d'água da bacia. Adicionalmente, recomendamos o monitoramento dos rios e riachos com o objetivo de verificar se as medidas adotadas seráo efetivas. 


\section{Referências}

AHEARN, D. S. et al. Land use and land cover influence on water quality in the last free-flowing river draining the western Sierra Nevada, California. Journal of Hydrology, v. 313, p. 234-247, 2005.

ALLAN, J. D.; CASTILLO, M. M. Stream ecology: structure and function of running waters. 2. ed. New York: Springer, 2007.

BIGGS, T. W. E.; DUNNE, T.; MURAOKA, T. Transport of water, solutes, and nutrients from a pasture hillslope, southwestern Brazilian Amazon. Hydrological Processes, v. 20, p. 2527-2547, 2006.

CASSIANO, C. C. O papel dos remanescentes florestais na manutençáo da qualidade da água em microbacias agrícolas. $2013.115 \mathrm{f}$. Dissertação (Mestrado em Engenharia Florestal) - Escola Superior de Agricultura "Luiz de Queiroz", Universidade de São Paulo, Piracicaba, SP, 2013.

COUCEIRO, S. R. M. et al. Deforestation and sewage effects on aquatic macroinvertebrates in urban streams in Manaus, Amazonas, Brazil. Hydrobiologia, v. 575, p. 271-284, 2007.

COURNANE, F. C. et al. Effects of cattle, sheep and deer grazing on soil physical quality and losses of phosphorus and suspended sediment losses in surface runoff. Agriculture, ecosystem and environment, v. 140, p. 264-272, 2011.

DANIEL, M. H. B. et al. Effects of urban sewage on dissolved oxygen, dissolved inorganic and organic carbon, and electrical conductivity of small streams along a gradient of urbanization in the Piraricaba river basin. Water, Air, and Soil Pollution, v. 136, p. 189-206, 2002.

ESTEVES, F. A.; AMADO, A. M. Nitrogênio. In: ESTEVES, F. A. Fundamentos de Limnologia. 3. ed. Rio de Janeiro: Interciência, 2011. p. 239-258.

GRANDE, M. D.; REZENDE, M. O. O.; ROCHA, O. Distribuição de compostos organoclorados nas águas e sedimentos da bacia do rio Piracicaba/SP. Química Nova, São Paulo, v. 26, n. 5, p. 678-686, 2003. 
GUPTA, V. K. et al. Chemical treatment technologies for waste-water recycling-an overview. RSC Advances, v. 2, p. 6380-6388, 2012.

HAUER, F. R.; LAMBERTI, G. A. Methods in stream ecology. 2. ed. New York: Academic Press/Elsevier, 2006.

HUNTER, H. M.; WALTON, R. S. Land-use effects on fluxes of suspended sediment, nitrogen and phosphorous from a river catchment of the Great Barrier Reef, Australia. Journal of Hydrology, v. 356, p. 131$146,2008$.

INSTITUTO BRASILEIRO DE GEOGRAFIA E ESTATÍSTICA IBGE. Censo Demográfico 2010. Apresenta informaçóes sobre os municípios brasileiros. Disponível em: <http://www.ibge.gov.br/home/estatistica/populacao/censo2010/>. Acesso em: 18 dez. 2011.

KRUSCHE, A. V. et al. Acid rain and nitrogen deposition in a sub-tropical watershed (Piracicaba): ecosystem consequences. Environmental Pollution, v. 121, p. 389-399, 2003.

MORI, G. B. A influência do uso da terra nas características limnológicas da água em microbacias: um estudo de caso na bacia do rio Corumbataí, SP. 2010. 47 f. Monografia (Graduação em Botânica) - Instituto de Biociências, Universidade Estadual Paulista "Júlio de Mesquita Filho", Rio Claro, 2010.

NADEN, P. S.; COOPER, D. M. Development of a sediment delivery model for application in large river basins. Hydrological Processes, v. 13, p. 1011-1034, 1999.

NASSIF, A. M. A. Recuperação da cobertura florestal na bacia do rio Corumbataí. Série Técnica IPEF, São Paulo, v. 12, n. 32, p. 121-126, 1998.

NEILL, C. et al. Deforestation alters the hydraulic and biogeochemical characteristics of small lowland Amazonian streams. Hydrological Processes, v. 20, p. 2563-2580, 2006.

PETERSON, B. J. et al. Control of nitrogen export form watersheds by headwater streams. Science, v. 292, p. 86-90, 2001. 
PROJETO CORUMBATAÍ. Plano Diretor: Conservação dos recursos hídricos por meio da recuperaçáo e a conservaçáo da cobertura florestal da bacia do rio Corumbataí. Piracicaba, SP: Relatório Técnico do IPEF, 2002.

RIBEIRO, M. C. et al. The Brazilian Atlantic Forest: how much is left, and how is the remaing forest distributed? Implications for conservation. Biological Conservation, v. 142, p. 1141-1153, 2009.

RIO CLARO. DEPARTAMENTO AUTÔNOMO DE ÁGUA E ESGOTO - DAAE. Sistema de tratamento de esgoto. 2015. Disponível em: <http://www.daaerioclaro.sp.gov.br>. Acesso em: 18 ago. 2015.

RODRIGUES, R. R. A vegetação de Piracicaba e municípios de entorno. Circular Técnica IPEF, São Paulo, v. 189, p. 1-18, 1999.

RUDORFF, B. F. T. et al. Studies on the rapid expansion of sugarcane for ethanol production in Sáo Paulo State (Brazil) using Landsat data. Remote Sensing, v. 2, p. 1057-1076, 2010.

SCHWENDENMANN, L.; VELDKAMP, E. The role of dissolved organic carbon, dissolved organic nitrogen, and dissolved inorganic nitrogen in a tropical wet forest ecosystem. Ecosystems, v. 8, p. 339-351, 2005.

SILVA, D. M. L. et al. Can land use changes alter carbon, nitrogen and major ion transport in subtropical Brazilian streams? Scientia Agricola, v. 64, n. 4, p. 317-324, 2007.

VALENTE, R. O. A.; VETTORAZZI, C. A. Mapeamento de uso e cobertura do solo da Bacia do rio Corumbataí, SP. Circular técnica IPEF, Sáo Paulo, v. 196, p. 1-9, 2003.

VALENTE, R. O. A.; VETTORAZZI, C. A. Avaliação da estrutura florestal da bacia hidrográfica do rio Corumbataí, SP. Scientia Florestalis, v. 68, p. 45-57, 2005. 


\title{
CAPÍTULO 12
}

\section{Cartografia geoambiental da bacia do rio do Monjolinho (Sáo Paulo)}

\author{
Leandro Contri Campanelli \\ Reinaldo Lorandi \\ José Augusto de Lollo
}

\section{Introdução}

A Bacia Hidrográfica do Rio do Monjolinho (BHRM) possui cerca de $275 \mathrm{~km} 2$ (ESPÍNDOLA, 2000) e está localizada nos municípios de São Carlos (maior parte) e Ibaté, no estado de São Paulo (Figura 1). Essa bacia, segundo a proposta de Strahler (1952), pode ser classificada como de quarta ordem.

O município de São Carlos tem aproximadamente $1 / 3$ de sua área na bacia do Tietê-Jacaré; e 2/3, na bacia do Mogi-Guaçu. A área urbana do município está quase toda inserida na BHRM, uma sub-bacia da bacia do Tietê-Jacaré. $\mathrm{O}$ município apresenta área de $1.137,303 \mathrm{~km}^{2}$ e população de 221.950 habitantes, com $96 \%$ da população na área urbana (IBGE, 2010).

As cabeceiras do rio do Monjolinho fornecem água para o abastecimento público de $15 \%$ da cidade, enquanto a sub-bacia do ribeirão do Feijão contribui com $35 \%$, sendo o restante obtido de poços no Aquífero Guarani (SÃO CARLOS, 2007). Barbosa et al. (2011) ressaltam que o Aquífero Guarani vem sofrendo um processo difuso de contaminação em sua área de afloramento no estado de Sáo Paulo em terrenos naturalmente vulneráveis à infiltraçáo de contaminantes. Segundo os autores, o avanço do uso da terra para as atividades agrícolas que utilizam agroquímicos, como cana-de-açúcar, café, cítricos e milho, configura o principal fator gerador de contaminação sobre as águas subterrâneas deste aquífero. 
FIGURA 1 - Localização da Bacia Hidrográfica do Rio do Monjolinho no município de São Carlos, São Paulo, Brasil

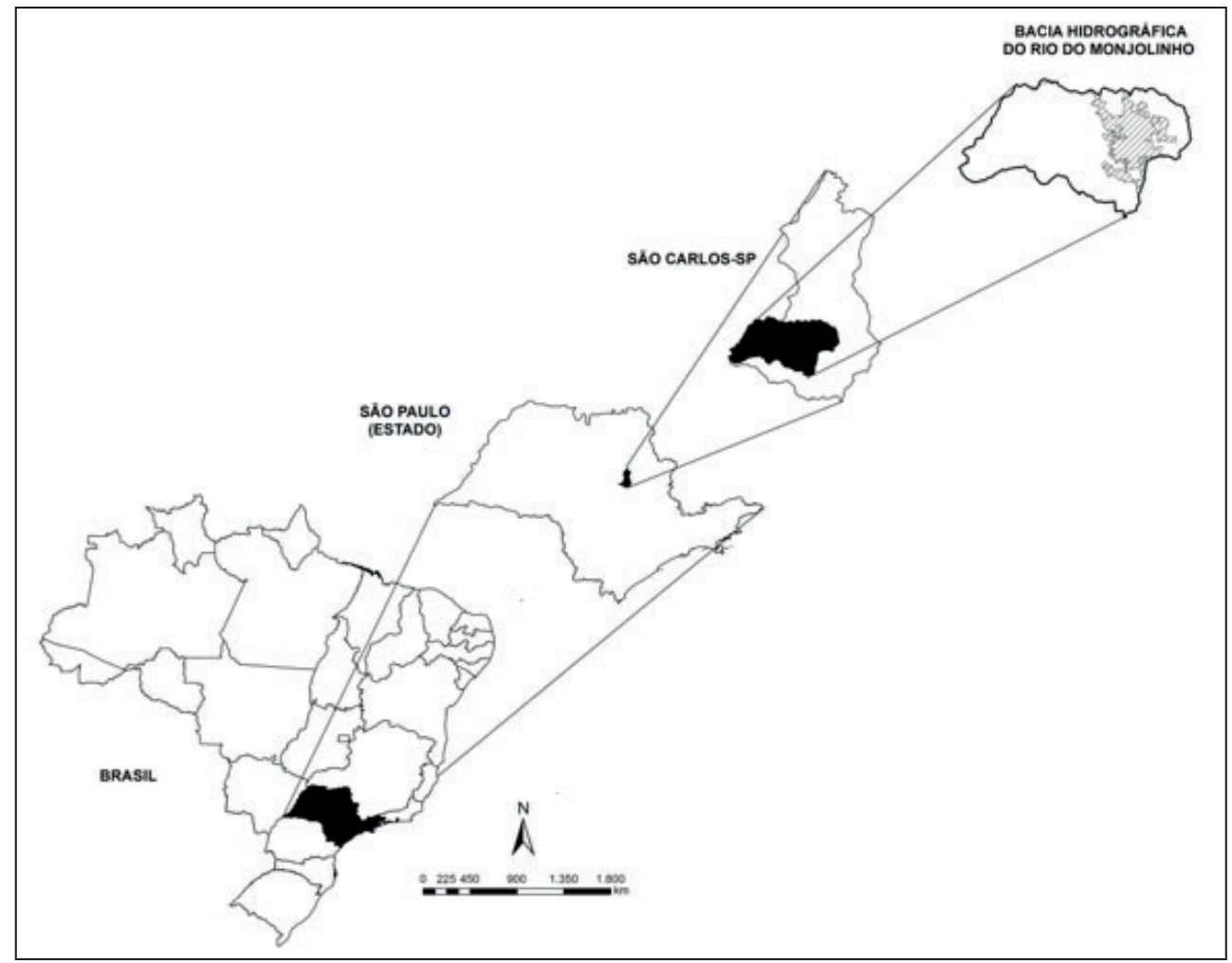

Fonte: Campanelli (2012).

A Estação de Tratamento de Esgotos (ETE Monjolinho) realiza o tratamento de $85 \%$ do esgoto sanitário gerado. Parte dos esgotos sanitários provenientes da região do bairro Cidade Aracy ainda é lançada nas sub-bacias dos córregos da Água Quente e da Água Fria, contribuindo para a degradação dos seus recursos hídricos.

O município de Ibaté apresenta área de $290,663 \mathrm{~km}^{2}$ e população de 30.734 habitantes (IBGE, 2010), e a base de sua economia é a produção sucroalcooleira. O abastecimento público de água potável em Ibaté é integralmente realizado a partir de poços (ANA, 2010).

$\mathrm{O}$ rio do Monjolinho possui extensão de aproximadamente 43,25 km, nascendo no Planalto de São Carlos, a leste do município de São Carlos, na cota de $900 \mathrm{~m}$, percorrendo o sentido leste-oeste, dando origem a uma ampla planície de inundação (ESPÍNDOLA, 2000). 
Campanelli e Amorim (2009) levantaram as condiçóes ambientais da BHRM com o objetivo de registrar os principais impactos ambientais decorrentes de atividades antrópicas e as intervençóes do poder público para minimizá-los. Nesse estudo, o curso do rio foi dividido em três setores (Setor 1 - região da nascente; Setor 2 - setor urbano de São Carlos; Setor 3 - fora do perímetro urbano).

No Setor 1, registrou-se a disposição final de resíduos sólidos domésticos e ausência de vegetação ciliar; no Setor 2, disposição de resíduos sólidos domésticos e de resíduos de construção e demolição, ausência de vegetação ciliar, obras viárias em fundo de vale, processos erosivos nas margens, pontos de assoreamento, pontos de inundaçáo, iniciativas de recomposição de vegetaçáo ciliar, obras de contenção de margens e construção de canal sob o leito dos córregos (macrodrenagem); no Setor 3, registrou-se ausência de vegetação ciliar e acúmulo de resíduos sólidos domésticos e áreas de solo exposto decorrentes de atividades minerárias. No Setor 3, estão instaladas a UHE do Monjolinho e a ETE Monjolinho.

A Lei Municipal nº 13.944, de 2006, dispóe sobre a criação das Áreas de Proteção e Recuperação dos Mananciais do Município (APREM), com o intuito de promover o pleno desenvolvimento da funçáo social de abastecimento da população por meio da proteção e recuperação da qualidade e da quantidade das águas superficiais (SÃO CARLOS. Lei 13.944/2006). Parte da BHRM, especificamente a montante da estação de captação de água do Espraiado, encontra-se enquadrada nesta lei, que proíbe a armazenagem de efluentes industriais nas áreas de mananciais por ela delimitadas, bem como a disposição final de resíduos sólidos.

Um estudo de Lorandi et al. (2001) sobre a caracterização do meio físico na porção superior da BHRM (porção enquadrada na Lei Municipal $\mathrm{n}^{\circ} 13.944$, de 2006) apresenta uma carta de potencial à erosáo laminar desta porção da bacia na escala de 1:10.000. Tal documento cartográfico mostra que $53 \%$ da área apresenta baixo potencial à erosão laminar (áreas ocupadas por pastagens) e $47 \%$ apresenta potencial moderado, requerendo a adoção de medidas para evitar os processos erosivos.

Sé (1992) apresenta um levantamento de informaçóes da BHRM (clima, formações geológicas, geomorfologia, pedologia, cobertura vegetal, recursos hídricos, uso e ocupação do solo) e parâmetros físicos, químicos e biológicos, indicativos de qualidade de água. As informaçóes permitiram relacionar a influência de processos ocorrentes ao longo da superfície da bacia sobre os ambientes lóticos. 
Com o objetivo de avaliar a percepçáo da população urbana e rural residente na BHRM quanto aos problemas ambientais ali existentes, Dornelles (2006) aplicou questionários cujos resultados mostram que o poder público foi considerado um dos principais responsáveis $(76,9 \%)$ pelos problemas ambientais existentes. De acordo com esse mesmo autor, as sub-bacias pertencentes à BHRM apresentam diferentes características com distintos graus de urbanização.

\section{Caracterizaçáo da bacia do rio do Monjolinho}

O clima na regiáo onde se localiza a BHRM é classificado como Cwb, segundo sistemática de Köppen, com uma estação seca (de abril a setembro) e outra chuvosa (de dezembro a fevereiro), com médias anuais de precipitação entre 1.200 mm e 1.500 mm (ESPÍNDOLA, 2000).

Quanto às formas de relevo, há o predomínio de colinas médias e amplas com declividades inferiores a 15\%, planícies aluviais e morros testemunhos (SÉ, 1992). Os morros testemunhos caracterizam-se por relevos residuais, cuja origem encontra-se associada a processos de desnudação. As planícies aluviais são terrenos baixos e relativamente planos, sujeitos às inundaçóes periódicas dos rios e localizam-se ao longo do curso do rio do Monjolinho.

As formaçôes geológicas de superfície características da bacia são Formação Serra Geral e Formação Botucatu (Grupo São Bento), Formação Adamantina (Grupo Bauru) e Formação Pirambóia (Grupo São Bento). Também há ocorrência de Suítes Básicas e Depósitos Recentes do Quaternário.

$\mathrm{Na}$ BHRM, ocorrem aquíferos fraturados (Aquífero Serra Geral e Aquífero Fraturado) e aquíferos sedimentares (Aquífero Bauru, Aquífero Aluvionar e Aquífero Guarani).

Os materiais inconsolidados que ocorrem na área podem ser divididos em dois grandes grupos: materiais retrabalhados e materiais residuais. Os materiais retrabalhados resultam da decomposição das rochas associada a algum tipo de transporte ou mobilização. Os materiais residuais são aqueles que não sofreram transporte ou retrabalhamento após a decomposição da rocha mãe.

Segundo Zuquette (1981), Aguiar (1989) e Muro (2000), na BHRM ocorrem os seguintes materiais inconsolidados: Cobertura Residual da For- 
mação Adamantina; Cobertura Residual da Formação Serra Geral; Residual Intrusivas Básicas; Cobertura dos Sedimentos Arenosos I; Retrabalhado Arenoso I; Retrabalhado Arenoso II; Retrabalhado Coluvionar; Retrabalhado Botucatu; Aluvião; e Afloramento de Rocha Sedimentar.

De acordo com Souza, Santos e Palhares (2000), os tipos de solos presentes ao longo da BHRM são: Latossolo Vermelho-Amarelo, Latossolo Vermelho-Escuro e Latossolo Roxo; Areias Quartzosas Profundas; Solos Litólicos; Solos Hidromórficos; Terra Roxa Estruturada.

Segundo Silva, Abdon e Paranaguá (2000), as formações vegetais originalmente presentes na BHRM são: Floresta Estacional Semidecidual Submontana e Aluvial; Savana Florestada (Cerradáo); Savana Arborizada (Cerrado) e Capoeiras, sendo que a Floresta Estacional Semidecidual Submontana corresponde à vegetação das escarpas da bacia, e a Floresta Estacional Semidecidual Aluvial ocorre ao longo dos rios. Na bacia, inúmeras áreas de mata ciliar foram removidas em função do desenvolvimento urbano de Sáo Carlos e da expansão das atividades agrícolas.

A Savana Florestada ocorre restrita às áreas areníticas lixiviadas com solos profundos, e a Savana Arborizada corresponde a um subgrupo de formação natural ou antropizada, sujeito ao fogo anual. As Capoeiras ocorrem em áreas em processo de sucessáo ecológica e caracterizam-se por vegetação secundária composta por gramíneas e arbustos esparsos (SILVA; ABDON; PARANAGUÁ, 2000).

\section{Métodos e Técnicas de Pesquisa}

O método adotado para o zoneamento geoambiental da BHRM, voltado para a aptidão ao processo de ocupação urbana, fundamentou-se na concepção de zoneamento geoambiental analítico de Zuquette e Gandolfi (2004), considerando os atributos do meio físico e uso e ocupaçáo do solo e a metodologia proposta por Vedovello (2000). As três etapas desenvolvidas foram:

- Elaboração de mapas temáticos básicos do meio físico (Mapa de Uso e Ocupação do Solo, Mapa de Formações Geológicas de Superfície, Mapa de Materiais Inconsolidados, Mapa de Unidades Aquíferas e Carta de Declividades);

- Elaboração do Mapa de Unidades Básicas de Compartimentação 
da Bacia Hidrográfica do Rio do Monjolinho;

- Elaboraçáo da Carta de Zoneamento Geoambiental Analítico da Bacia Hidrográfica do Rio do Monjolinho: Aptidão ao Processo de Ocupação Urbana.

O Mapa de Unidades Básicas de Compartimentação (UBC) é produto da análise integrada das seguintes informaçóes do meio físico: formaçóes geológicas de superfície; unidades aquíferas; declividades do terreno; formas de relevo e perfis de encostas. E a Carta de Zoneamento Geoambiental Analítico é resultado da avaliação das UBC de acordo com cinco componentes geotécnicos: alterabilidade, declividade, espessura do manto de alteração, permeabilidade e tipo de material do manto de alteração; o que possibilitou o enquadramento das unidades nas seguintes classes de aptidão ao processo de ocupação urbana: Propícia, Pouco Favorável e Imprópria.

\section{Caracterização dos atributos físicos e do uso e ocupaçáo do solo}

A Carta de Declividades foi gerada com sete classes de declividades: $0 \%$ a $5 \%, 5 \%$ a $10 \%, 10 \%$ a $15 \%, 15 \%$ a $20 \%, 20 \%$ a $30 \%, 30 \%$ a $45 \%$ e $>45 \%$.

As formaçóes geológicas de superfície identificadas na área foram: Formação Serra Geral (14\%), Formação Botucatu (28\%), Formação Adamantina (34\%), Formaçáo Pirambóia (3\%), Quaternário (2\%) e Suítes Básicas (1\%).

A Formação Serra Geral é composta por rochas eruptivas básicas extrusivas, como basalto, e corpos intrusivos (diques e sills), intercalados com arenito eólico. As rochas eruptivas básicas são compactas, de coloração escura, com granulometria que varia de muito fina a menos fina e com a presença de minerais ferromagnesianos. Na BHRM, a Formação Serra Geral aflora predominantemente na porção central da área (MACIEL, 2000). Nessa formação, são comuns paredóes verticais como formas de relevo, os quais podem originar espessas coberturas coluvionares nos sopés. Secundariamente, ocorrem morros suavemente abaulados, provavelmente relacionados ao aplainamento dado ao relevo após o derrame basáltico (AGUIAR, 1989).

O material rochoso proveniente da Formação Serra Geral é muito explorado para uso em pavimentação não asfáltica em estradas vicinais, em função de seu elevado grau de fraturamento (ZUQUETTE, 1981). 
A Formação Botucatu caracteriza-se por arenitos de coloração esbranquiçada a avermelhada. Os sedimentos apresentam granulometria fina a média, com a presença de grãos quartzosos foscos, arredondados, esféricos e equidimensionais, altamente silicificados e com ausência de matriz argilosa. A porção silicificada dos arenitos permite a extração de blocos e lajes para construçáo civil (ZUQUETTE, 1981). Segundo Maciel (2000), na BHRM, a Formação Botucatu aparece ao sul e também ao longo do rio do Monjolinho.

A Formação Adamantina é composta de arenitos de granulação fina, coloração que varia de róseo a castanho, estratificação cruzada e espessuras variando entre $2 \mathrm{~m}$ e $20 \mathrm{~m}$, alternados com bancos de lamitos, siltitos e arenitos lamíticos de coloração que varia de castanho-avermelhado a cinza-castanho. De acordo com Maciel (2000), na BHRM, a Formação Adamantina é predominante ao longo de toda a porção norte.

A Formação Pirambóia, por sua vez, caracteriza-se por arenitos de granulometria que varia de fina a média, de coloração amarelada e com predominância de finos (ZUQUETTE, 1981). Geralmente, tal formação encontra-se recoberta por solos arenosos e com grau de intemperismo muito semelhante ao da Formação Botucatu.

A faixa intemperizada da Formação Pirambóia é pouco espessa, apresentando espessura em torno de um metro e aumentando, possivelmente, em áreas nas quais o arenito apresenta-se fraturado e, portanto, sujeito a maior percolação de água. $\mathrm{O}$ grau de fraturamento não é tão intenso quanto o da Formação Botucatu. O solo proveniente da Formação Pirambóia é utilizado para fins agrícolas, sendo que no mesmo desenvolve-se tanto pastagens como cultivos agrícolas anuais (ZUQUETTE, 1981). Na BHRM, a Formação Pirambóia ocorre na porção Sudoeste.

As Suítes Básicas são observadas nas proximidades da foz do rio do Monjolinho e caracterizam-se por rochas intrusivas magmáticas básicas que afloram em decorrência de processos erosivos das rochas sobrejacentes. Com relação aos Depósitos Recentes do Quaternário, estes caracterizam-se por materiais sedimentares de granulação fina e argilas e matéria orgânica depositados nas planícies aluviais.

As áreas recobertas pelas unidades de materiais inconsolidados são: Cobertura dos Sedimentos Arenosos I (30\%), Cobertura Residual da Formação Adamantina (4\%), Cobertura Residual da Formação Serra Geral (10,1\%), Residual Intrusivas Básicas (1\%), Retrabalhado Arenoso I 
(27,5\%), Retrabalhado Arenoso II (1,6\%), Retrabalhado Botucatu (3\%), Retrabalhado Coluvionar (0,5\%), Aluvião (1,9\%) e Afloramento de Rocha Sedimentar $(2,8 \%)$.

A Cobertura Residual da Formação Adamantina ocorre nos vales dos córregos em altitudes menores que $800 \mathrm{~m}$. Tais materiais apresentam coloração avermelhada, possuem espessura maior que $1 \mathrm{~m}$ e apresentam altos valores de plasticidade (ZUQUETTE, 1981). A areia fina é o principal constituinte (em torno de $60 \%$ ), seguido da areia média (de $2 \%$ a $20 \%$ ), silte (de $5 \%$ a $28 \%$ ) e argila (de $10 \%$ a $63,5 \%$ ).

Os materiais da Cobertura Residual da Formação Serra Geral podem ser encontrados nas encostas de inclinaçáo acentuada, onde possuem pequena espessura e apresentam-se com fragmentos da rocha mãe em quantidades apreciáveis; e em áreas planas, com espessuras mais acentuadas e sem fragmentos. Predominam grãos menores que 0,074 mm (ZUQUETTE, 1981). As proporçóes das fraçôes granulométricas que compóem estes materiais são: areia fina, entre $10 \%$ e $35 \%$; silte, entre $20 \%$ e $45 \%$; e argila, entre $25 \%$ e $60 \%$.

As Coberturas dos Sedimentos Arenosos I são encontradas em quase toda a porção Norte da área de estudo e possuem a areia fina como a fração granulométrica predominante. A coloração destes materiais varia entre amarelado e avermelhado e a espessura entre $50 \mathrm{~cm}$ e $5 \mathrm{~m}$. Tais materiais recobrem parte das formaçóes geológicas Botucatu, Serra Geral e Bauru. Pode-se verificar a ocorrência de uma camada de seixos entre tais formaçóes e a própria cobertura de material inconsolidado (ZUQUETTE, 1981). Aguiar (1989) classificou tais materiais como Material Retrabalhado Arenoso III.

Os materiais inconsolidados do tipo Retrabalhado Arenoso I recobrem os materiais residuais da Formação Botucatu e possuem contribuição das unidades Serra Geral e Bauru, sendo predominantemente arenosos. Apresentam certa homogeneidade ao longo do perfil e ocorrência de voçorocas. A coloração varia de amarelada a avermelhada e a fração granulométrica predominante é a areia fina $(60 \%$ a $80 \%)$, com areia média em torno de $5 \%$ a $25 \%$ e argila chegando a $10 \%$.

Os materiais inconsolidados Retrabalhado Arenoso II estão associados aos magmatitos básicos. Apresentam maiores teores de finos (fraçáo argila varia de $15 \%$ a $40 \%$ ), com expressiva quantidade de areia proveniente dos arenitos da Formação Botucatu e coloração avermelhada a amarelada. 
Do ponto de vista mineralógico, a fração areia contém quartzo, magnetita e ilmenita; a fração argila é composta por caulinita, gibbsita e óxidos de ferro (MURO, 2000).

Os materiais inconsolidados do tipo Retrabalhado Coluvionar são provenientes das encostas do basalto, onde ocorre a mistura com areias do Botucatu. Apresentam coloração avermelhada e espessura que varia entre $10 \mathrm{~m}$ e $20 \mathrm{~m}$. As áreas de ocorrência deste tipo de material inconsolidado caracterizam-se por grande instabilidade, ocasionada por fatores como a ação antrópica (MURO, 2000).

Os materiais inconsolidados do tipo Aluvionares ocupam os fundos de vales e são materiais depositados pela ação dos rios e por enxurradas, que possuem grandes quantidades de matéria orgânica e coloração escura. Materiais sedimentares de granulação fina e argila também fazem parte da composição destes materiais inconsolidados. E os materiais inconsolidados do tipo Retrabalhado Botucatu são originados a partir dos materiais arenosos provenientes da Formação Botucatu, cujas rochas sofreram algum tipo de transporte ou mobilização. São materiais fortemente retrabalhados por abrasáo seletiva em clima semiárido e árido de ambiente desértico.

De acordo com a Figura 2, as unidades aquíferas da BHRM são: Aquífero Bauru (34\%), Aquífero Guarani (31\%), Aquífero Aluvionar (2\%), Aquífero Serra Geral (14\%) e Aquífero Fraturado (1\%). 


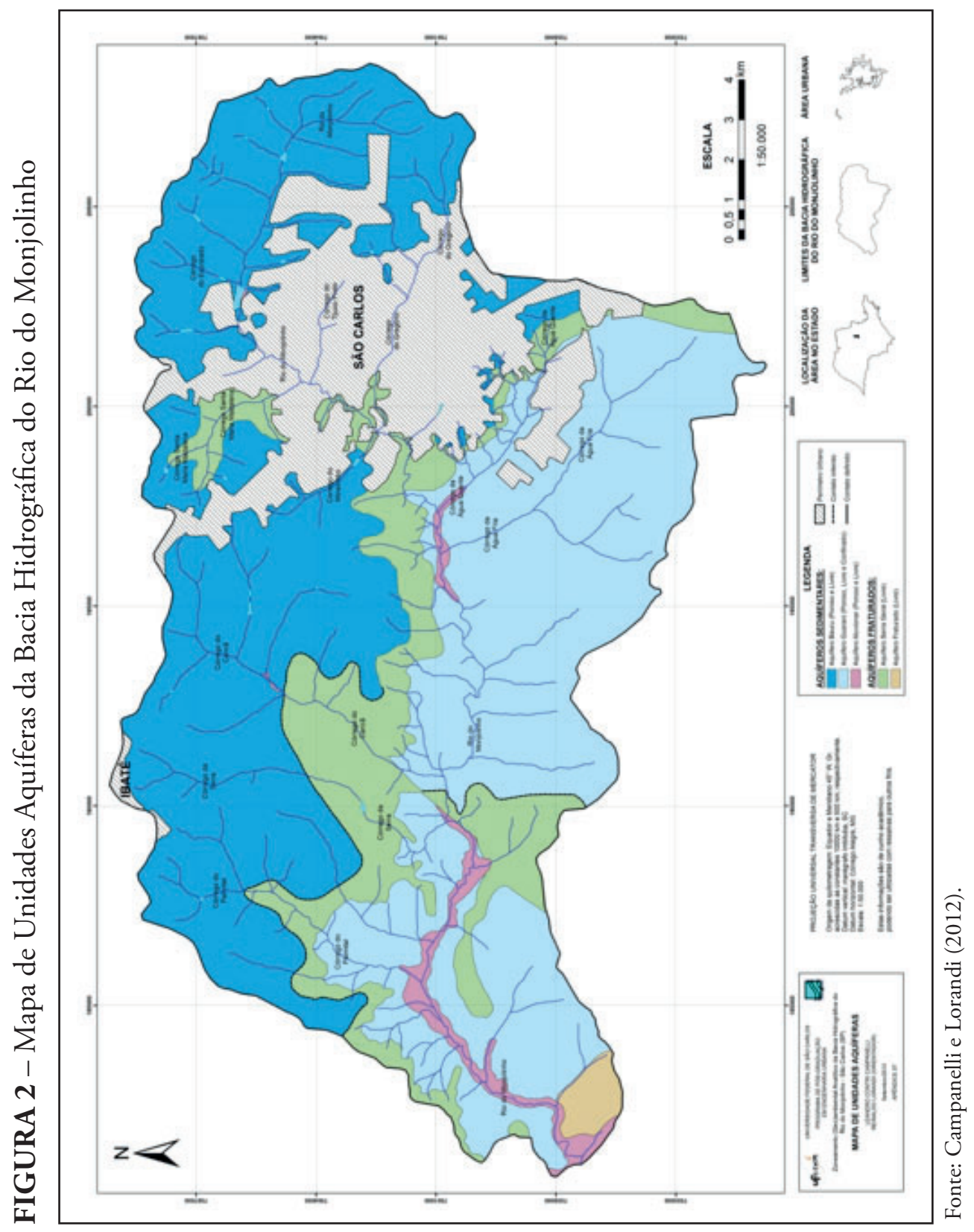

O Aquífero Serra Geral, que se caracteriza por ser fraturado e livre, foi formado entre 138 e 127 milhões de anos atrás, sendo constituído por basaltos originados dos derrames da Formação Serra Geral e intrusóes de diabásio. Nos basaltos, os vazios favoráveis ao armazenamento e ao fluxo de água subterrânea são fraturas de resfriamento dos derrames e, devido a esforços tectônicos posteriores, decorrentes da movimentação da crosta 
terrestre (IRITANI; EZAKI, 2008). O Aquífero Serra Geral caracteriza-se por apresentar água de excelente qualidade para usos diversificados, incluindo abastecimento público.

O aquífero associado às Suítes Básicas é denominado Aquífero Fraturado, caracterizado como aquífero livre.

O Aquífero Bauru é poroso e livre, sendo formado por rochas sedimentares arenosas, areno-argilosas e siltosas pertencentes ao Grupo Bauru e depositadas em ambiente desértico e fluvial, sob clima árido e semiárido, há mais de 65 milhóes de anos (IRITANI; EZAKI, 2008).

$\mathrm{Na}$ porção superior, os arenitos são intercalados por camadas de sedimentos de granulometria fina ou possuem cimentação carbonática, o que reduz a capacidade de armazenamento e a transmissividade do aquífero. $\mathrm{Na}$ porçáo basal, predominam arenitos com baixo teor de finos, conferindo maior produtividade aos poços perfurados.

O aquífero associado aos Depósitos Recentes do Quaternário é chamado Aquífero Aluvionar, que se caracteriza por ser sedimentar, poroso e livre. Este aquífero ocorre em fundos de vale, em depósitos aluviais sedimentares e de matéria orgânica.

O Aquífero Guarani é associado às Formaçóes Botucatu e Pirambóia e caracteriza-se por ser sedimentar, poroso, livre ou confinado. É constituído por arenitos de granulação média a fina, depositados por ação eólica em ambiente desértico há cerca de 130 milhóes de anos. Pelo fato de apresentarem grande quantidade de poros interconectados, possibilitam o armazenamento de grandes volumes de água (IRITANI; EZAKI, 2008).

O Mapa de Uso e Ocupação do Solo foi elaborado a partir de imagem de satélite atualizada e com o apoio de três campanhas de campo para verificação. As classes identificadas foram: perímetro urbano (18\%), canade-açúcar (42\%), pastagem (12\%), reflorestamento (2\%), capoeira (4\%), vegetação nativa $(21 \%)$ e solo exposto $(1 \%)$.

\section{Apresentação das unidades básicas de compartimentaçáo}

O Quadro 1 sintetiza as Unidades Básicas de Compartimetação (UBC) obtidas ao longo de toda a extensão da bacia e na sequência tem-se uma descrição de cada uma dessas unidades. 
QUADRO 1 - Síntese das Unidades Básicas de Compartimentação (UBC) identificadas para a Bacia Hidrográfica do Rio do Monjolinho.

\begin{tabular}{|c|c|c|c|}
\hline \multicolumn{4}{|c|}{ DOMÍNIO REGIONAL - BACIA SEDIMENTAR DO PARANÁ } \\
\hline PROVÍNCIA & ZONA & SUB-ZONA & UBC \\
\hline Quaternário (Q) & $\begin{array}{l}\text { Depósitos Recentes do } \\
\text { Quaternário (QUAT) }\end{array}$ & Planície (P) & Q,QUAT,P \\
\hline Cretáceo Superior (CS) & $\begin{array}{l}\text { Formação Adamantina - } \\
\text { Grupo Bauru (FAD) }\end{array}$ & $\begin{array}{l}\text { Planície (P) } \\
\text { Colina (C) } \\
\text { Morrote (M) } \\
\text { Morro Alto (MA) }\end{array}$ & $\begin{array}{l}\text { CS,FAD,P } 1 \text { a } 2 \\
\text { CS,FAD,C } 1 \text { a } 3 \\
\text { CS,FAD,M } 1 \text { a } 2 \\
\text { CS,FAD,MA } 1 \text { a } 2 \\
\end{array}$ \\
\hline \multirow[t]{2}{*}{ Juro-Cretáceo (JCR) } & $\begin{array}{l}\text { Formação Serra Geral - } \\
\text { Grupo São Bento (FSG) }\end{array}$ & $\begin{array}{l}\text { Planície (P) } \\
\text { Colina (C) } \\
\text { Morrote (M) } \\
\text { Morro Alto (MA) }\end{array}$ & $\begin{array}{l}\text { JCR,FSG,P } 1 \text { a } 4 \\
\text { JCR,FSG,C } 1 \text { a } 3 \\
\text { JCR,FSG,M } 1 \text { a } 4 \\
\text { JCR,FSG,MA } 1 \text { a } 2\end{array}$ \\
\hline & Suítes Básicas (SB) & $\begin{array}{l}\text { Planície (P) } \\
\text { Colina (C) }\end{array}$ & $\begin{array}{l}\text { JCR,SB,P } \\
\text { JCR,SB,C }\end{array}$ \\
\hline Jurássico (J) & $\begin{array}{l}\text { Formação Botucatu - } \\
\text { Grupo São Bento (FBOT) }\end{array}$ & $\begin{array}{l}\text { Planície (P) } \\
\text { Colina (C) } \\
\text { Morrote (M) } \\
\text { Morro Alto (MA) } \\
\text { Cuesta (CT) }\end{array}$ & $\begin{array}{l}\text { J,FBOT,P } 1 \text { a } 3 \\
\text { J,FBOT,C } 1 \text { a } 3 \\
\text { J,FBOT,M } 1 \text { a } 3 \\
\text { J,FBOT,MA } 1 \text { a } 2 \\
\text { J,FBOT,CT }\end{array}$ \\
\hline Triássico-Jurássico (TJ) & Formação Piramboia (FPIR) & $\begin{array}{l}\text { Planície (P) } \\
\text { Colina (C) } \\
\text { Morrote (M) } \\
\text { Morro Alto (MA) }\end{array}$ & $\begin{array}{l}\text { TJ,FPIR,P } 1 \text { a } 2 \\
\text { TJ,FPIR,C } 1 \text { a } 3 \\
\text { TJ,FPIR,M } 1 \text { a } 3 \\
\text { TJ,FPIR,MA } 1 \text { a } 2\end{array}$ \\
\hline
\end{tabular}

Fonte: Campanelli (2012).

Descrição das UBC obtidas ao longo de toda a extensão da BHRM:

- Q,QUAT,P - Depósitos recentes do Quaternário em planície aluvionar, declividades de $0 \%$ a $5 \%$, perfil de encosta convexo-côncavo e Aquífero Aluvionar (sedimentar, poroso e livre).

- CS,FAD,P 1 - Formaçáo Adamantina (Grupo Bauru), forma de relevo do tipo planície, declividades de $0 \%$ a $5 \%$, perfil de encosta convexo-côncavo e Aquífero Bauru (sedimentar, poroso e livre).

- CS,FAD,P 2 - Formaçáo Adamantina (Grupo Bauru), forma de relevo do tipo planície, declividades de $0 \%$ a 5\%, perfil de encosta côncavo e Aquífero Bauru (sedimentar, poroso e livre).

- CS,FAD,C 1 - Formação Adamantina (Grupo Bauru), forma de relevo do tipo colina, declividades de $5 \%$ a $20 \%$, perfil de encosta convexo-côncavo e Aquífero Bauru (sedimentar, poroso e livre). 
- CS,FAD,C 2 - Formação Adamantina (Grupo Bauru), forma de relevo do tipo colina, declividades de $5 \%$ a $20 \%$, perfil de encosta côncavo e Aquífero Bauru (sedimentar, poroso e livre).

- CS,FAD,C 3 - Formaçáo Adamantina (Grupo Bauru), forma de relevo do tipo colina, declividades de $5 \%$ a $20 \%$, perfil de encosta convexo-retilíneo-côncavo e Aquífero Bauru (sedimentar, poroso e livre).

- CS,FAD,M 1 - Formação Adamantina (Grupo Bauru), forma de relevo do tipo morrote, declividades de $20 \%$ a $30 \%$, perfil de encosta convexo-côncavo e Aquífero Bauru (sedimentar, poroso e livre).

- CS,FAD,M 2 - Formação Adamantina (Grupo Bauru), forma de relevo do tipo morrote, declividades de $20 \%$ a $30 \%$, perfil de encosta côncavo e Aquífero Bauru (sedimentar, poroso e livre).

- CS,FAD,MA 1 - Formaçáo Adamantina (Grupo Bauru), forma de relevo do tipo morro alto, declividades de $30 \%$ a $45 \%$, perfil de encosta convexo-côncavo e Aquífero Bauru (sedimentar, poroso e livre).

- CS,FAD,MA 2 - Formaçáo Adamantina (Grupo Bauru), forma de relevo do tipo morro alto, declividades de $30 \%$ a $45 \%$, perfil de encosta côncavo e Aquífero Bauru (sedimentar, poroso e livre).

- JCR,FSG,P 1 - Formação Serra Geral (Grupo São Bento), forma de relevo do tipo planície, declividades de $0 \%$ a $5 \%$, perfil de encosta convexo-côncavo e Aquífero Serra Geral (fraturado e livre).

- JCR,FSG,P 2 - Formação Serra Geral (Grupo São Bento), forma de relevo do tipo planície, declividades de $0 \%$ a $5 \%$, perfil de encosta côncavo e Aquífero Serra Geral (fraturado e livre).

- JCR,FSG,P 3 - Formação Serra Geral (Grupo São Bento), forma de relevo do tipo planície, declividades de $0 \%$ a $5 \%$, perfil de encosta convexo-retilíneo-côncavo e Aquífero Serra Geral (fraturado e livre).

- JCR,FSG,P 4 - Formação Serra Geral (Grupo São Bento), forma de relevo do tipo planície, declividades de $0 \%$ a $5 \%$, perfil de encosta convexo e Aquífero Serra Geral (fraturado e livre).

- JCR,FSG,C 1 - Formação Serra Geral (Grupo São Bento), forma de relevo do tipo colina, declividades de $5 \%$ a $20 \%$, perfil de encosta convexo-côncavo e Aquífero Serra Geral (fraturado e livre).

- JCR,FSG,C 2 - Formação Serra Geral (Grupo São Bento), forma de relevo do tipo colina, declividades de $5 \%$ a $20 \%$, perfil de encosta côncavo e Aquífero Serra Geral (fraturado e livre).

- JCR,FSG,C 3 - Formação Serra Geral (Grupo São Bento), forma 
de relevo do tipo colina, declividades de $5 \%$ a $20 \%$, perfil de encosta convexo-retilíneo-côncavo e Aquífero Serra Geral (fraturado e livre).

- JCR,FSG,M 1 - Formaçáo Serra Geral (Grupo São Bento), forma de relevo do tipo morrote, declividades de $20 \%$ a $30 \%$, perfil de encosta convexo-côncavo e Aquífero Serra Geral (fraturado e livre).

- JCR,FSG,M 2 - Formação Serra Geral (Grupo São Bento), forma de relevo do tipo morrote, declividades de $20 \%$ a $30 \%$, perfil de encosta côncavo e Aquífero Serra Geral (fraturado e livre).

- JCR,FSG,M 3 - Formação Serra Geral (Grupo São Bento), forma de relevo do tipo morrote, declividades de $20 \%$ a $30 \%$, perfil de encosta convexo-retilíneo-côncavo e Aquífero Serra Geral (fraturado e livre).

- JCR,FSG,M 4 - Formação Serra Geral (Grupo São Bento), forma de relevo do tipo morrote, declividades de $20 \%$ a $30 \%$, perfil de encosta convexo e Aquífero Serra Geral (fraturado e livre).

- JCR,FSG,MA 1 - Formação Serra Geral (Grupo São Bento), forma de relevo do tipo morro alto, declividades de $30 \%$ a $45 \%$, perfil de encosta convexo-côncavo e Aquífero Serra Geral (fraturado e livre).

- JCR,FSG,MA 2 - Formação Serra Geral (Grupo São Bento), forma de relevo do tipo morro alto, declividades de $30 \%$ a $45 \%$, perfil de encosta côncavo e Aquífero Serra Geral (fraturado e livre).

- JCR,SB,P - Suítes Básicas, forma de relevo do tipo planície, declividades de $0 \%$ a 5\%, perfil de encosta convexo-côncavo e Aquífero Fraturado (livre).

- JCR,SB,C - Suítes Básicas, forma de relevo do tipo colina, declividades de $5 \%$ a $20 \%$, perfil de encosta convexo-côncavo e Aquífero Fraturado (livre).

- J,FBOT,P 1 - Formação Botucatu (Grupo São Bento), forma de relevo do tipo planície, declividades de $0 \%$ a $5 \%$, perfil de encosta convexo-côncavo e Aquífero Guarani (sedimentar, poroso, livre e confinado).

- J,FBOT,P 2 - Formação Botucatu (Grupo São Bento), forma de relevo do tipo planície, declividades de $0 \%$ a $5 \%$, perfil de encosta côncavo e Aquífero Guarani (sedimentar, poroso, livre e confinado).

- J,FBOT,P 3 - Formação Botucatu (Grupo São Bento), forma de relevo do tipo planície, declividades de $0 \%$ a $5 \%$, perfil de encosta convexo-retilíneo-côncavo e Aquífero Guarani (sedimentar, poroso, livre e confinado).

- J,FBOT,C 1 - Formação Botucatu (Grupo São Bento), forma de relevo do tipo colina, declividades de $5 \%$ a $20 \%$, perfil de encosta convexo-côncavo e Aquífero Guarani (sedimentar, poroso, livre e confinado). 
- J,FBOT,C 2 - Formação Botucatu (Grupo São Bento), forma de relevo do tipo colina, declividades de 5\% a 20\%, perfil de encosta côncavo e Aquífero Guarani (sedimentar, poroso, livre e confinado).

- J,FBOT,C 3 - Formação Botucatu (Grupo São Bento), forma de relevo do tipo colina, declividades de $5 \%$ a $20 \%$, perfil de encosta convexo-retilíneo-côncavo e Aquífero Guarani (sedimentar, poroso, livre e confinado).

- J,FBOT,M 1 - Formação Botucatu (Grupo São Bento), forma de relevo do tipo morrote, declividades de $20 \%$ a $30 \%$, perfil de encosta convexo-côncavo e Aquífero Guarani (sedimentar, poroso, livre e confinado).

- J,FBOT,M 2 - Formação Botucatu (Grupo São Bento), forma de relevo do tipo morrote, declividades de $20 \%$ a $30 \%$, perfil de encosta côncavo e Aquífero Guarani (sedimentar, poroso, livre e confinado).

- J,FBOT,M 3 - Formação Botucatu (Grupo São Bento), forma de relevo do tipo morrote, declividades de $20 \%$ a $30 \%$, perfil de encosta convexo-retilíneo-côncavo e Aquífero Guarani (sedimentar, poroso, livre e confinado).

- J,FBOT,MA 1 - Formação Botucatu (Grupo São Bento), forma de relevo do tipo morro alto, declividades de $30 \%$ a $45 \%$, perfil de encosta convexo-côncavo e Aquífero Guarani (sedimentar, poroso, livre e confinado).

- J,FBOT,MA 2 - Formação Botucatu (Grupo São Bento), forma de relevo do tipo morro alto, declividades de $30 \%$ a $45 \%$, perfil de encosta convexo-retilíneo-côncavo e Aquífero Guarani (sedimentar, poroso, livre e confinado).

- J,FBOT,CT - Formação Botucatu (Grupo São Bento), forma de relevo do tipo cuesta, declividade maior que $45 \%$, perfil de encosta convexo-retilíneo-côncavo e Aquífero Guarani (sedimentar, poroso, livre e confinado).

- TJ,FPIR,P 1 - Formação Pirambóia, forma de relevo do tipo planície, declividades de $0 \%$ a 5\%, perfil de encosta convexo-côncavo e Aquífero Guarani (sedimentar, poroso, livre e confinado).

- TJ,FPIR,P 2 - Formação Pirambóia, forma de relevo do tipo planície, declividades de $0 \%$ a $5 \%$, perfil de encosta convexo-retilíneo-côncavo e Aquífero Guarani (sedimentar, poroso, livre e confinado).

- TJ,FPIR,C 1 - Formação Pirambóia, forma de relevo do tipo colina, declividades de $5 \%$ a 20\%, perfil de encosta convexo-côncavo e Aquífero Guarani (sedimentar, poroso, livre e confinado). 
- TJ,FPIR,C 2 - Formação Pirambóia, forma de relevo do tipo colina, declividades de $5 \%$ a $20 \%$, perfil de encosta convexo-retilíneo-côncavo e Aquífero Guarani (sedimentar, poroso, livre e confinado).

- TJ,FPIR,C 3 - Formaçáo Pirambóia, forma de relevo do tipo colina, declividades de 5\% a 20\%, perfil de encosta convexo e Aquífero Guarani (sedimentar, poroso, livre e confinado).

- TJ,FPIR,M 1 - Formação Pirambóia, forma de relevo do tipo morrote, declividades de $20 \%$ a $30 \%$, perfil de encosta convexo-côncavo e Aquífero Guarani (sedimentar, poroso, livre e confinado).

- TJ,FPIR,M 2 - Formação Pirambóia, forma de relevo do tipo morrote, declividades de $20 \%$ a $30 \%$, perfil de encosta convexo-retilíneo-côncavo e Aquífero Guarani (sedimentar, poroso, livre e confinado).

- TJ,FPIR,M 3 - Formaçáo Pirambóia, forma de relevo do tipo morrote, declividades de $20 \%$ a $30 \%$, perfil de encosta convexo e Aquífero Guarani (sedimentar, poroso, livre e confinado).

- TJ,FPIR,MA 1 - Formação Pirambóia, forma de relevo do tipo morro alto, declividades de $30 \%$ a $45 \%$, perfil de encosta convexo-côncavo e Aquífero Guarani (sedimentar, poroso, livre e confinado).

- TJ,FPIR,MA 2 - Formação Pirambóia, forma de relevo do tipo morro alto, declividades de 30\% a 45\%, perfil de encosta convexo-retilíneo-côncavo e Aquífero Guarani (sedimentar, poroso, livre e confinado).

\section{Apresentação do zoneamento geoambiental analítico}

A Carta de Zoneamento Geoambiental Analítico da Bacia Hidrográfica do Rio do Monjolinho: Aptidão ao Processo de Ocupaçáo Urbana (Figura 3) foi elaborada em escala 1:50.000. Este documento é produto da integração de informações geológico-geotécnicas diversificadas, e compartimentou a área da bacia nas seguintes classes de aptidáo ao processo de ocupação urbana: Áreas Propícias, Pouco Favoráveis e Impróprias.

As porcentagens referentes a cada uma das classes de aptidão ao processo de ocupação urbana em relação à área total da bacia são: Áreas Propícias (61\%), Áreas Pouco Favoráveis (14\%) e Áreas Impróprias (7\%).

As Áreas Propícias correspondem àquelas que podem ser ocupadas mediante a execução de procedimentos técnicos específicos para a implantação das obras visando a estabilização de cortes no terreno (VEDOVELLO, 2000). 


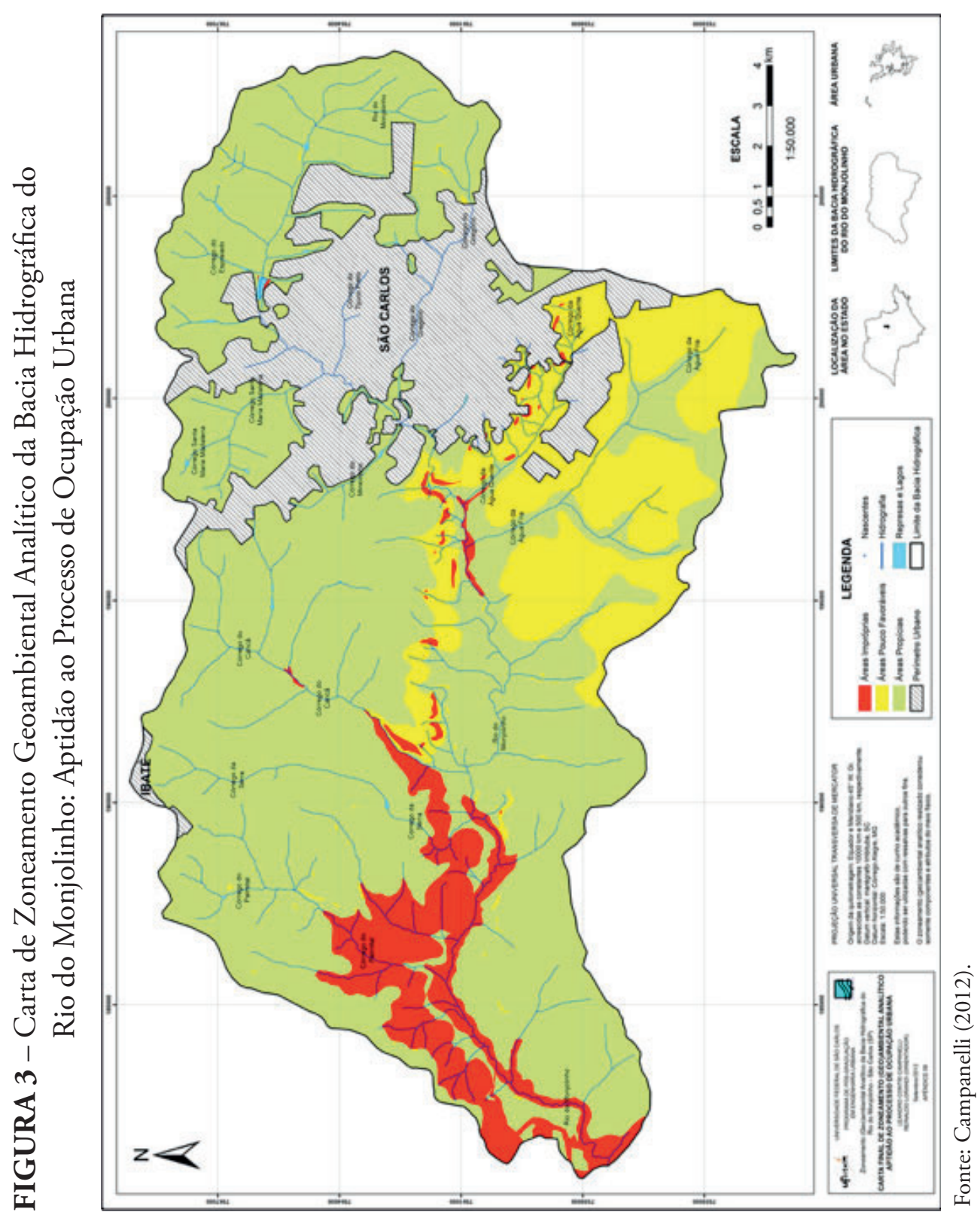

As Áreas Propícias ao processo de ocupação urbana na BHRM (61\%) ocorrem nas porçóes Norte e Sudoeste, onde predominam as formaçóes geológicas de superfície Adamantina e Botucatu. As unidades aquíferas predominantes são Aquífero Bauru e Aquífero Guarani. Os materiais inconsolidados são: Cobertura dos Sedimentos Arenosos I, Cobertura Residual da Formação Adamantina e Retrabalhado Arenoso I; materiais arenosos com permeabilidade alta a média. As declividades estáo entre $0 \%$ 
e $20 \%$, o perfil de encosta predominante é o convexo-côncavo associado ao relevo suave ondulado. Predominam os Latossolos, e secundariamente ocorre Terra Roxa Estruturada. Todas essas características geológico-geotécnicas integradas propiciam a implantaçáo de infraestrutura urbana sem altos investimentos.

As Áreas Pouco Favoráveis correspondem àquelas que podem ser ocupadas a partir da elaboraçáo de projetos técnicos que demandam elevados investimentos e que possuem o respaldo de infraestruturas adequadas (VEDOVELLO, 2000).

$\mathrm{Na}$ BHRM, tais áreas correspondem a $14 \%$ da bacia e estão localizadas na sua porção Central, onde predominam a Formação Serra Geral e o Aquífero Serra Geral. Os tipos de materiais inconsolidados predominantes são Retrabalhado Arenoso II e Cobertura Residual da Formação Serra Geral. Ambos se caracterizam por média permeabilidade. As declividades predominantes variam de $20 \%$ a $>45 \%$, e o perfil de encosta predominante é o côncavo em relevo forte ondulado. O tipo pedológico predominante é a Terra Roxa Estruturada, solo espesso e bem drenado.

Apesar dos materiais inconsolidados de textura argilosa e do tipo de solo possibilitarem a ocupação urbana, as declividades que variam de $20 \%$ a $>45 \%$ e o perfil de encosta do tipo côncavo impóem certas restriçóes ao processo, fazendo com que as áreas em questão sejam consideradas pouco favoráveis à ocupação urbana. A ocupação urbana nessas áreas pode necessitar de projetos técnicos específicos e altos investimentos em infraestrutura.

A porção Sudeste da bacia também foi classificada como Pouco Favorável à ocupação urbana. Nessa área há ocorrência de Areias Quartzosas Profundas. Trata-se de área de recarga do aquífero Guarani e que já apresenta histórico de ocupação urbana irregular e ocorrência de processos erosivos de grande porte.

$\mathrm{E}$ as Áreas Impróprias correspondem àquelas que apresentam restriçôes geotécnicas, mesmo diante da elaboração de projetos técnicos específicos. Os riscos geotécnicos aos quais as obras implantadas nestas áreas encontram-se submetidas sáo: incidência de processos erosivos severos, escorregamentos, movimentos gravitacionais de massa, queda de blocos, entre outros (VEDOVELLO, 2000).

Nas Áreas Impróprias ao processo de ocupação urbana (7\%), porção Centro-Oeste da BHRM, predominam as formaçóes Pirambóia, Botucatu 
e Depósitos Recentes do Quaternário. As unidades aquíferas predominantes são Aquífero Aluvionar e Aquífero Guarani. Os materiais inconsolidados predominantes são Retrabalhado Botucatu, Afloramento de Rocha Sedimentar e Aluvião (Retrabalhado Aluvionar). As declividades variam de $20 \%$ a $>45 \%$, e o perfil de encosta predominante é do tipo convexo-retilíneo-côncavo, os quais dão origem a um relevo que varia de forte ondulado a escarpado. Há ocorrência de solos Litólicos, imaturos e rasos.

\section{Consideraçóes Finais}

O Mapa de Uso e Ocupação do Solo mostra que o uso predominante é o cultivo de cana-de-açúcar (42\%), atividade responsável por significativas alteraçóes na paisagem e pela redução de remanescentes de vegetaçáo nativa.

A Formação Adamantina é a formação geológica de superfície predominante (34\%), e a unidade de material inconsolidado predominante é Cobertura de Sedimentos Arenosos I (30\%).

Duas unidades aquíferas são expressivas na bacia, o Aquífero Bauru (34\%) e o Aquífero Guarani (31\%). Ambos são aquíferos sedimentares com permeabilidade intergranular, são grandes mananciais de água subterrânea para diferentes usos e possuem áreas de recarga ao longo da bacia. O processo de ocupaçáo da bacia deve considerar a fragilidade das áreas de recarga dos aquíferos em termos de processos difusos de contaminação das águas subterrâneas.

A Unidade Básica de Compartimentação predominante na bacia é CS,FAD,P 1 a 2 (21,34\%), composta pela Formação Adamantina, forma de relevo do tipo planície, perfis de encostas convexo-côncavo e côncavo e Aquífero Bauru.

A integração de informações geológico-geotécnicas permitiu gerar a Carta de Zoneamento Geoambiental Analítico, que compartimentou a área da bacia nas seguintes classes de aptidáo ao processo de ocupaçáo urbana: Áreas Propícias, Pouco Favoráveis e Impróprias.

As informaçóes geológico-geotécnicas integradas, com destaque para as altas declividades que variam de $20 \%$ a $>45 \%$, perfil de encosta do tipo convexo-retilíneo-côncavo, relevo que varia de forte ondulado a escarpado, solos imaturos e com pequeno desenvolvimento de perfil e presença de afloramentos rochosos, dificultam grandemente o processo de ocupaçáo 
urbana, com destaque para a implantação de infraestruturas urbanas, e tornam essas áreas susceptíveis a riscos geotécnicos, fazendo com que as mesmas sejam classificadas como Impróprias à ocupação urbana.

A presença de Depósitos Recentes do Quaternário em planícies aluvionares é outra característica que impede a ocupação urbana e isso ocorre em quatro pontos específicos da bacia: a) trecho do rio do Monjolinho, situado entre o córrego do Cancã e a foz do próprio rio do Monjolinho; b) pequeno trecho do córrego do Cancá; c) trecho do rio do Monjolinho situado nas proximidades dos córregos da Água Quente e da Água Fria; d) trecho do rio do Monjolinho nas proximidades do córrego do Espraiado. Não foram identificadas Áreas Favoráveis ao processo de ocupação urbana na bacia. 


\section{Referências}

AGÊNCIA NACIONAL DAS ÁGUAS - ANA. Atlas de abastecimento urbano de água. Apresenta informações sobre o abastecimento urbano de água nos municípios brasileiros. 2010. Disponível em: <http://atlas. ana.gov.br/Atlas/forms/Home.aspx>. Acesso em: 18 jul. 2015.

AGUIAR, R. L. Mapeamento geotécnico preliminar da área de expansão urbana de São Carlos - SP: contribuição ao planejamento. 1989. 127 f. Dissertação (Mestrado em Geotecnia) - Universidade de São Paulo, São Carlos, SP, 1989.

BARBOSA, M. C. et al. Avaliação do perigo de contaminação do Sistema Aquífero Guarani em sua área de afloramento do Estado de Sáo Paulo decorrente das atividades agrícolas. Águas Subterrâneas, v. 25, n. 1, p. 1-14, 2011.

INSTITUTO BRASILEIRO DE GEOGRAFIA E ESTATÍSTICA IBGE. Censo Demográfico de 2010. Apresenta informaçôes sobre os municípios brasileiros. Disponível em: <http:/www.ibge.gov.br/home/ estatistica/populacao/censo2010/default.shtm>. Acesso em: 18 jul. 2015.

CAMPANELLI, L. C.; AMORIM, S. V. de. Levantamento de condiçóes ambientais - estudo de caso: córrego do Monjolinho. In: JORNADA CIENTÍFICA E TECNOLÓGICA DA UNIVERSIDADE FEDERAL DE SÃO CARLOS, 8., 2009, São Carlos, SP. Anais... São Carlos, SP: Universidade Federal de São Carlos, 2009.

CAMPANELLI, L. C. Zoneamento (geo)ambiental analítico da bacia hidrográfica do rio do Monjolinho - Sáo Carlos (SP). 2012. 136 f. Dissertação (Mestrado em Engenharia Urbana) - Universidade Federal de São Carlos, São Carlos, SP, 2012.

CAMPANELLI, L. C.; LORANDI, R. Importância da carta de unidades aquíferas para a elaboração de zoneamento (geo)ambiental - estudo de caso na bacia hidrográfica do rio do Monjolinho (Brasil, São Paulo, São Carlos). Revista de Geología Aplicada a la Ingeniería y al Ambiente, v. 29, p. 83-90, 2012. 
DORNELLES, C. T. A. Percepçáo ambiental: uma análise na bacia hidrográfica do rio do Monjolinho, Sáo Carlos, SP. 2006. 176 f. Dissertação (Mestrado em Ciências da Engenharia Ambiental) - Universidade de São Paulo, São Carlos, SP, 2006.

ESPÍNDOLA, E. L. G. O rio do Monjolinho: um estudo de caso. In: ESPÍNDOLA, E. L. G.; SILVA, J. S. V.; MARINELLI, C. E.; ABDON, M. M. A bacia hidrográfica do rio do Monjolinho. São Carlos, SP: Rima, 2000. p. 36-40.

IRITANI, M. A.; EZAKI, S. As águas subterrâneas do Estado de Sáo Paulo. São Paulo: Secretaria do Meio Ambiente, 2008.

LORANDI, R. et al. Carta de potencial à erosáo laminar da parte superior da bacia do córrego do Monjolinho (São Carlos, SP). Revista Brasileira de Cartografia, São Paulo, v. 53, p. 111-117, 2001.

MACIEL, G. de C. Geologia e geomorfologia. In: ESPÍNDOLA, E. L. G.; SILVA, J. S. V.; MARINELLI, C. E.; ABDON, M. M. A bacia hidrográfica do rio do Monjolinho. São Carlos, SP: Rima, 2000. p. 41-48.

MURO, M. D. Carta de zoneamento para seleçáo de áreas frente à instalaçáo de aterros sanitários no município de Sáo Carlos - SP. 2000. 172 f. Dissertação (Mestrado em Geotecnia) - Universidade de São Paulo, São Carlos, SP, 2000.

SÃO CARLOS. Cartas ambientais do município de Sáo Carlos. Edição Comemorativa do Sesquicentenário - $150^{\circ}$ aniversário. São Carlos, SP: Prefeitura Municipal, 2007.

SÃO CARLOS. Lei 13.944, de 12 de dezembro de 2006. Dispóe sobre a criação das Áreas de Proteção e Recuperação dos Mananciais do Município de São Carlos - APREM. Disponível em: <http://www.saocarlos.sp. gov.br/images/stories/concursos2009/lei\%2013944_06\%20-\%20texto. pdf>. Acesso em: 18 jul. 2015.

SÉ, J. A. S. O rio do Monjolinho e sua bacia hidrográfica como integradores de sistemas ecológicos: um conjunto de informaçóes para o início de um processo de pesquisas ecológicas, de educação, planejamento e gerenciamento ambientais a longo prazo. 1992. 381 f. Dissertação (Mestrado em Ciências da Engenharia Ambiental) - Universidade de Sáo Paulo, São Carlos, SP, 1992. 
SILVA, J. dos S. V. da; ABDON, M. de M.; PARANAGUÁ, P. A. Remanescentes de vegetação. In: ESPÍNDOLA, E. L. G.; SILVA, J. S. V.; MARINELLI, C. E.; ABDON, M. M. A bacia hidrográfica do rio do Monjolinho. São Carlos, SP: Rima, 2000. p. 77-87.

SOUZA, P. A. P.; SANTOS, M. B. dos; PALHARES, J. C. Pedologia. In: ESPÍNDOLA, E. L. G.; SILVA, J. S. V.; MARINELLI, C. E.; ABDON, M. M. A bacia hidrográfica do rio do Monjolinho. São Carlos, SP: Rima, 2000. p. 49-59.

STRAHLER, A. N. Hypsometric (area-altitude) analysis of erosional topography. Bulletin Geological Society of America, v. 63, n. 10, p. 1117-1142, 1952.

VEDOVELLO, R. Zoneamentos geotécnicos aplicados à gestáo ambiental, a partir de unidades básicas de compartimentaçáo - UBCs. 2000. 154 f. Tese (Doutorado em Geologia) - Universidade Estadual Paulista, Rio Claro, SP, 2000.

ZUQUETTE, L. V. Mapeamento geotécnico preliminar da região de Sáo Carlos. 1981. 86 f. Dissertaçáo (Mestrado em Geotecnia) - Universidade de São Paulo, São Carlos, SP, 1981.

ZUQUETTE, L. V.; GANDOLFI, N. Cartografia geotécnica. São Paulo: Oficina de Textos, 2004. 


\title{
A legislaçáo ambiental da bacia do rio Claro, Sáo Paulo
}

\author{
Maria Eugênia Bruck de Moraes \\ Reinaldo Lorandi \\ Ricardo Pedro Guazzelli Rosário \\ José Augusto de Lollo \\ Mariana Bruck de Moraes Ponna Schiavetti \\ Felipe de Souza Pimenta
}

\section{Introduçáo}

As bacias hidrográficas são unidades espaciais de dimensões variadas, onde se organizam os recursos hídricos em funçáo das relações entre a estrutura geológico-geomorfológica e as condiçôes climáticas (MAGALHÁES JÚNIOR, 2007). Pires, Santos e Del Prette (2002) e Magalhães Júnior (2007) destacam que o conceito de bacia hidrográfica tem sido ampliado e expandido e passou a ser utilizado na área de planejamento como unidade de gestão ambiental.

No processo de planejamento e gestáo ambiental de bacias hidrográficas, destaca-se o papel fundamental da legislação ambiental correlata. A integração da legislação ambiental ao planejamento das bacias pode contribuir para um sistema de governança ambiental de ótima qualidade e mais eficiente do que o atual. No Brasil, as leis que permeiam questôes ambientais são inúmeras, variando entre os órgãos governamentais, o que dificulta a sua aplicação, ou até mesmo o seu conhecimento na íntegra.

No âmbito federal, algumas das leis que se destacam na gestão de bacias são: o Código de Águas, a Política Agrícola, o Código Florestal e a Política Nacional de Recursos Hídricos. Já em âmbito estadual, destaca-se o Decreto no 32.955, de 1991, que dispóe sobre a preservação dos depósitos naturais de águas subterrâneas no estado de São Paulo.

Segundo Feitosa et al. (2008), a bacia hidrográfica do rio Claro en- 
contra-se localizada na Província Hidrogeológica da Bacia Sedimentar do Paraná, reconhecida pelo seu potencial hidrogeológico, incluindo as principais unidades aquíferas da bacia sedimentar.

Diante desse contexto, este capítulo tem o propósito de analisar a legislação ambiental incidente na bacia do rio Claro, buscando verificar as oportunidades e adversidades na conservação dos recursos hídricos. E, no intuito de aprofundar o conhecimento da situaçáo legal da bacia, também se apresenta a distribuição espacial das suas áreas protegidas e analisa-se a ocupação das mesmas, considerando as restriçóes legais que incidem sobre tais áreas.

\section{Caracterizaçáo da bacia do rio Claro}

Segundo o Fundo Estadual de Recursos Hídricos (FEHIDRO, 2011), o território brasileiro foi dividido, num primeiro nível, em Regióes Hidrográficas estabelecidas pela Resolução n 32 do Conselho Nacional de Recursos Hídricos, de 15 de outubro de 2003, que definiu a divisão hidrográfica nacional. Na caracterização em nível federal, a bacia hidrográfica do rio Mogi Guaçu pertence à Região Hidrográfica do Paraná, que é constituída pela bacia hidrográfica do rio Paraná, situada no território nacional.

Num nível macro, a bacia hidrográfica do rio Mogi Guaçu, denominada Unidade de Gerenciamento de Recursos Hídricos 09 (UGRHI09), no estado de São Paulo, está inserida na bacia hidrográfica do rio Grande.

No estado de São Paulo, a bacia hidrográfica do rio Mogi Guaçu está localizada na regiáo nordeste e apresenta limites com as unidades de gerenciamento de recursos hídricos: Piracicaba/Capivari/Jundiaí; Tietê/Jacaré; Tietê/Batalha; Turvo/Grande; Baixo Pardo/Grande e Pardo.

Em 1995, a bacia do rio Mogi Guaçu foi subdividida em compartimentos econômico-ecológicos a partir da elaboração do "Macrozoneamento das Bacias dos Rios Mogi Guaçu, Pardo e Médio-Grande” (SÃO PAULO. SMA, 1995), sendo que tais compartimentos foram readequados em 2008, objetivando facilitar o planejamento de açóes ambientais. Assim, foram realizados ajustes nos limites do compartimento Alto Mogi para que fosse englobado o trecho crítico da bacia, onde é desenvolvido o Projeto Estiagem, coordenado pela Companhia de Tecnologia de Saneamento Ambiental (CETESB) (Regional Pirassununga). E também foram alterados os limites entre o compartimento Médio Mogi (antigo Médio Mogi 
Superior) e o Baixo Mogi (Antigo Médio Mogi Inferior) para que o seus limites coincidissem com os divisores de água dos principais afluentes do rio Mogi Guaçu.

Uma das sub-bacias do rio Mogi Guaçu é a bacia do rio Claro (Figura 1), inserida no compartimento Médio Mogi Superior e cujo rio principal está classificado como um curso d'água classe 2 de acordo com o estabelecido pela Resolução n 357 do Conselho Nacional do Meio Ambiente (BRASIL. CONAMA 357/2005). Com base em cartogramas na escala 1: 2.500.000 (FEITOSA et al., 2008), a bacia do rio Claro está inserida em uma regiáo caracterizada por apresentar valores de capacidade específica acima de $10 \mathrm{~m}^{3} / \mathrm{h} \cdot \mathrm{m}^{-1}$. 


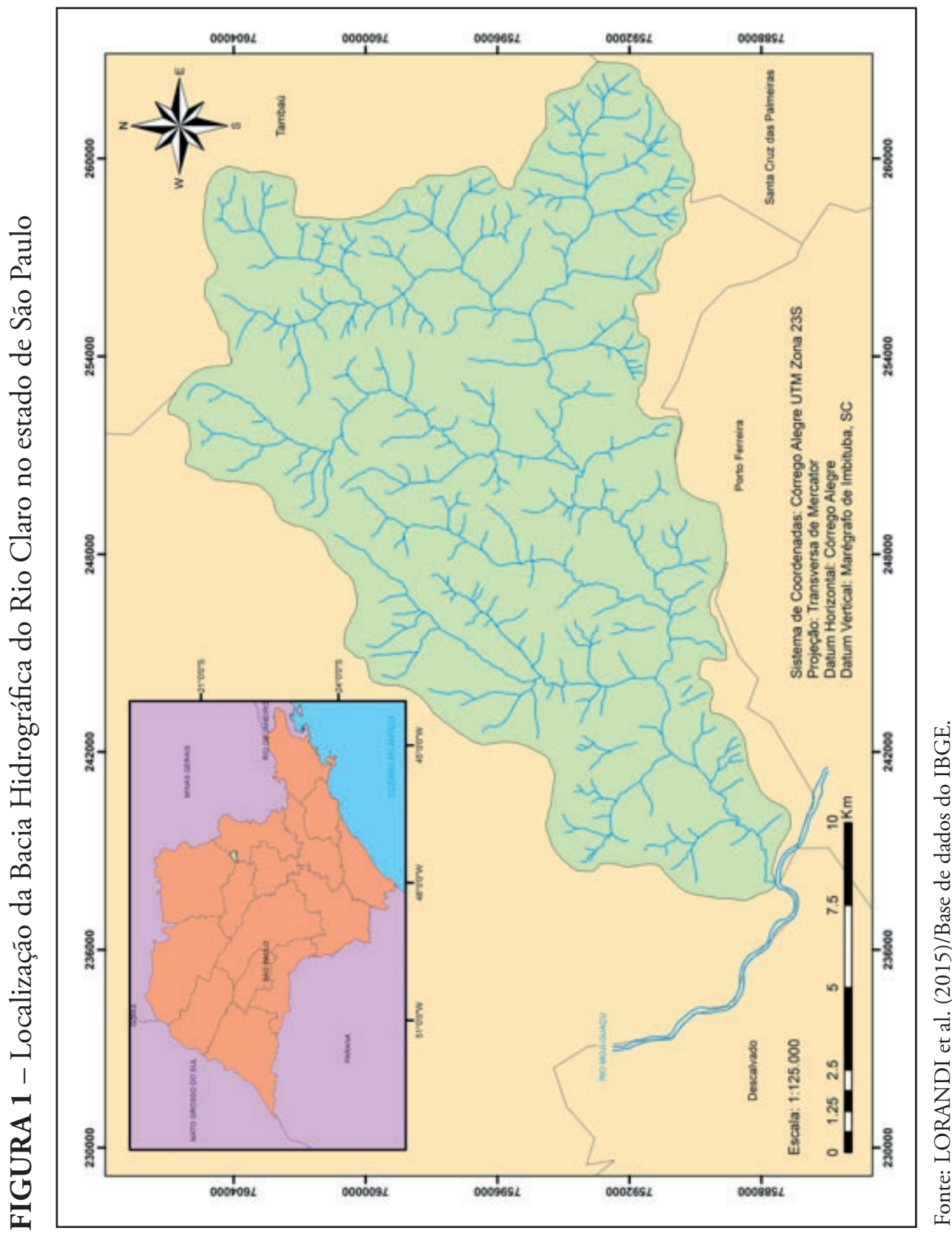

Uma análise da distribuição das águas subterrâneas no estado de Sáo Paulo, com base em cartogramas na escala 1: 1.000.000, mostra que a bacia encontra-se territorialmente envolvida pelos aquíferos Guarani (aflorante) e Serra Geral Intrusivas (SÃO PAULO, 2005). Essa bacia abrange uma área de $251,91 \mathrm{~km}^{2}$ e engloba parte dos municípios de Porto Ferreira, Santa Rita do Passa Quatro, Pirassununga, Santa Cruz da Estrela, Tambaú e Descalvado. 
O clima na região estudada é classificado, de acordo com o sistema de Köppen, como sendo do tipo Cwa, isto é, mesotérmico úmido subtropical de inverno seco, em que a temperatura média do mês mais frio é inferior a $18^{\circ} \mathrm{C}$ e a do mês mais quente ultrapassa $22^{\circ} \mathrm{C}$. Quanto ao balanço hídrico, há uma nítida distinção entre a estação chuvosa (outubro a abril) e a estação seca (maio a setembro), que apresenta deficiência hídrica (LORANDI et al., 2015).

A cobertura vegetal original da regiáo, pertencente ao subtipo Floresta Latifoliada Tropical, com o decorrer do tempo, foi quase totalmente desmatada, restando, atualmente, poucas áreas preservadas (LORANDI et al., 2015).

Segundo a divisão geomorfológica do estado de São Paulo (SÃO PAULO. FFLCH/USP-IPT-FAPESP, 1997), a bacia está localizada na Unidade Morfoestrutural da Bacia Sedimentar do Paraná, abrangendo parte da Unidade Morfoescultural Depressão Periférica Paulista, esculpida quase que totalmente nos sedimentos paleo-mesozoicos da bacia. Tal morfoescultura é representada na área pela unidade morfológica denominada Depressão Mogi Guaçu, que apresenta modelado constituído basicamente por colinas de topos tabulares amplos, com vales entalhados até $20 \mathrm{~m}$ e dimensão interfluvial entre 1.750 e $3.750 \mathrm{~m}$. As cotas altimétricas predominantes estão entre 500 e $650 \mathrm{~m}$, e as declividades predominantes situam-se entre $5 \%$ e $10 \%$.

A bacia possui sete formações geológicas: Formação Corumbataí (Permiano), Formação Piramboia (Triássico), Formação Botucatu (Jura-Cretáceo), Formação Serra Geral e Intrusivas Básicas (Jura-Cretáceo), Formação Santa Rita do Passa-Quatro (Terciário), Formação Pirassununga (Terciário) e os Depósitos Recentes (Quaternário) (São Paulo-IG, 1981a, 1981b e 1984).

\section{Métodos e Técnicas de Pesquisa}

Inicialmente, foi realizado o levantamento cartográfico, bibliográfico e legal, considerando os documentos disponíveis inerentes aos municípios que pertencem à bacia do rio Claro. Posteriormente, foi feita a leitura e interpretação dos documentos jurídicos, utilizando-se o método hipotético-dedutivo para verificar a efetividade da legislação ambiental para a conservação dos recursos hídricos na área de estudo. 
Para a elaboração da Carta de Legislação Ambiental da Bacia Hidrográfica do Rio Claro (SP), foram utilizados os mapas de hidrografia, formaçóes geológicas e hipsometria em escala 1: 50.000, elaborados em trabalhos anteriores por Lorandi et al. (2015), os quais foram sobrepostos no Sistema de Informação Geográfica (SIG) ArcGIS 10, conforme o esquema metodológico apresentado na Figura 2.

$\mathrm{Na}$ delimitação das áreas protegidas, foram adotados os critérios mais restritivos quanto ao nível de preservação apresentados pela Lei Federal $n^{\circ}$ 12.651/2012 e pelo Decreto Estadual n ${ }^{\circ} 32.955 / 1991$, de acordo com o exposto no Quadro 1. Os critérios aqui adotados também foram definidos em função de sua aplicabilidade na bacia do rio Claro.

FIGURA 2 - Fluxograma do método adotado na elaboração da Carta de Legislação Ambiental da Bacia Hidrográfica do Rio Claro (SP)

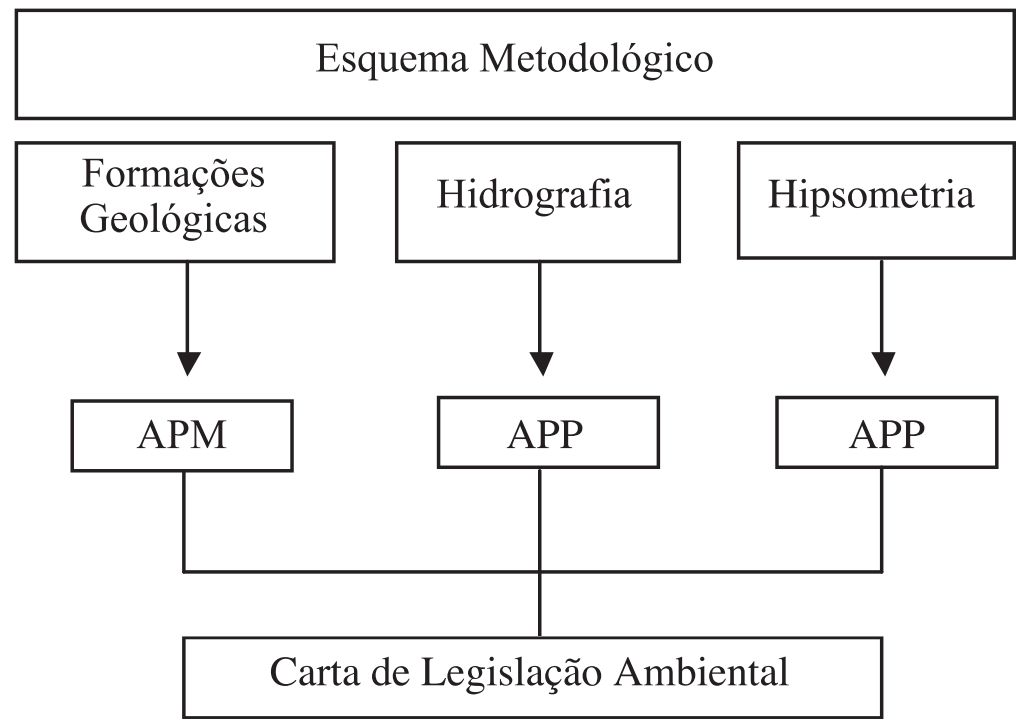

Fonte: elaborado pelos autores. 
QUADRO 1 - Critérios adotados na delimitação das áreas protegidas na Bacia Hidrográfica do Rio Claro (SP)

\begin{tabular}{|l|l|l|}
\hline Áreas protegidas & Critério & Referência \\
\hline áreas marginais aos rios & faixa de $30 \mathrm{~m}$ & Código Florestal \\
\hline áreas marginais aos lagos & faixa de $50 \mathrm{~m}$ & Código Florestal \\
\hline áreas marginais às nascentes & faixa de $50 \mathrm{~m}$ & Código Florestal \\
\hline áreas de topo & topo de morros & Código Florestal \\
\hline $\begin{array}{l}\text { áreas com potencialidade de recarga de } \\
\text { aquífero profundo }\end{array}$ & áreas de proteção máxima & Decreto Estadual \\
\hline
\end{tabular}

Fonte: elaborado pelos autores.

Para a análise da ocupaçáo do solo na bacia do rio Claro, mediante as restriçôes estabelecidas pela legislação ambiental, foram utilizados os mapas de formaçóes geológicas, uso e ocupação do solo e de declividades do terreno, em escala 1: 50.000 também elaborados anteriormente por Lorandi et al. (2015), os quais foram sobrepostos à Carta de Legislaçáo Ambiental por meio do SIG ArcGIS 10.

\section{Análise da legislaçáo ambiental correlata}

A legislação ambiental nacional trata de alguns pontos essenciais para a conservação dos recursos hídricos na área de estudo. No âmbito federal, apresentam-se o Código de Águas, a Política Agrícola, o Código Florestal e a Política Nacional de Recursos Hídricos.

O Código de Águas (Decreto $\mathrm{n}^{\circ}$ 24.643) (BRASIL. Decreto 24.643/1934), por ser mais antigo, nada traz sobre a conservação ou exploração de áreas pertencentes a bacias hidrográficas, disciplinando, em seus 205 artigos, sobre o que se entende por águas públicas, privadas e comuns, além de definir as formas de navegação, concessão e seu uso para obtenção de energia.

Já a Política Agrícola (Lei no 8.171) (BRASIL. Lei 8.171/1991) estabelece as bacias hidrográficas como unidades básicas de planejamento do uso, da conservação e da recuperação dos recursos naturais. E destaca que a proteção do meio ambiente e dos recursos naturais deverá ter programas plurianuais e planos operativos anuais, elaborados pelos órgáos competentes, mantidos ou não pelo Poder Público, sob a coordenação da União e das Unidades da Federação. 
O Código Florestal (Lei no 12.651) (BRASIL. Lei 12.651/2012) disciplina, dentre outras formas de proteção, as Áreas de Preservação Permanente (APP) que têm a função de preservar locais frágeis, como beiras de rios, topos de morros e encostas que náo podem ser desmatados para não causar erosóes e deslizamentos, além de proteger nascentes, fauna, flora e biodiversidade, entre outros.

$\mathrm{O}$ art. $4^{\mathrm{o}}$ do referido Código estabelece como APP, em zonas rurais ou urbanas, as faixas marginais dos rios de largura mínima de: $30 \mathrm{~m}$, para os cursos d'água de menos de $10 \mathrm{~m}$ de largura e $50 \mathrm{~m}$, para os que tenham de $10 \mathrm{~m}$ a $50 \mathrm{~m}$ de largura; ainda as áreas no entorno dos lagos e lagoas naturais, em faixa com largura mínima de $100 \mathrm{~m}$, em zonas rurais, exceto para o corpo d'água com até 20 ha de superfície, cuja faixa marginal será de $50 \mathrm{~m}$ em zonas rurais e de $30 \mathrm{~m}$ em zonas urbanas.

Assim como as áreas no entorno das nascentes e dos olhos d'água devem ser preservadas num raio mínimo de $50 \mathrm{~m}$. Também devem ser mantidas as encostas ou partes destas com declividade superior a $45^{\circ}$, equivalente a $100 \%$ na linha de maior declive.

O mesmo Código ainda institui que, nos imóveis rurais com até 15 módulos fiscais, admite-se a prática da aquicultura no entorno de lagos e margens de rios; desde que sejam adotadas práticas sustentáveis de manejo de solo e água e de recursos hídricos, garantindo sua qualidade e quantidade de acordo com as normas dos Conselhos Estaduais de Meio Ambiente, e que estejam de acordo com os respectivos planos de bacia ou planos de gestão de recursos hídricos.

Vale ressaltar que a Lei ${ }^{\circ} 12.651$ estabelece alguns limites, ainda que não muito expressivos, para a intervenção ou a supressão de vegetaçáo nativa em APP. Essa somente poderá ocorrer em casos de declarada utilidade pública, de interesse social ou de baixo impacto ambiental. Todavia, esta regra geral pode ser alterada quando da verificação das disposiçóes transitórias no capítulo XIII dessa lei. Apesar de alguns dispositivos necessitarem de regulamentação, outros estão positivados, em especial a proteção das APP ao longo dos cursos d'água.

A largura das faixas de vegetaçáo ao longo dos rios passou a variar com o tamanho da propriedade. A medida da propriedade foi estabelecida em módulos fiscais, unidade de medida utilizada pelo Instituto Nacional de Colonização e Reforma Agrária (INCRA), a fim de verificar o grau de utilização da propriedade. O tamanho do módulo fiscal varia de município 
para município em todos os estados do Brasil, assim dificultando a mensuração das áreas a serem restauradas. Mas a regra da lei é única: imóveis com até um módulo fiscal devem ter $5 \mathrm{~m}$ de APP, imóveis com área superior a um e até dois módulos fiscais devem possuir $8 \mathrm{~m}$ de APP, e os imóveis com área maior de dois e menor que 4 ha devem possuir a APP de $15 \mathrm{~m}$ (artigo 61-A).

Em muitos casos, a área de proteção no entorno das nascentes será de $15 \mathrm{~m}$ (parágrafo $5^{\circ}$. Do artigo 61-A). O entorno das lagoas é o mesmo para o entorno dos rios nas propriedades de até quatro módulos fiscais, e de $30 \mathrm{~m}$ para aqueles com área superior a quatro módulos fiscais.

Outra proteção especial é o entorno de veredas (parágrafo $7^{\circ}$. Do artigo 61-A) que estabelece a proteção do entorno das mesmas de até 30 m para imóveis de até quatro módulos fiscais, e de 50 m para imóveis com mais de quatro módulos fiscais.

O artigo 61-B dispóe que as APP de imóveis com até dois módulos fiscais, em 22 de julho de 2008 , podem ter um total de $10 \%$ e de $20 \%$ para os imóveis com área entre dois e quatro módulos fiscais.

Acredita-se que o estabelecimento do Cadastro Ambiental Rural (CAR) - (artigo 29 e seguintes do Código Florestal) - pode tornar-se a melhor ferramenta de gestáo ambiental do Brasil. Nesse cadastro, devem constar os dados da propriedade, como rios, áreas de vegetaçáo, áreas de uso econômico, bem como outros atributos da propriedade, como benfeitorias, terrenos acidentados, servidóes, entre outros.

Apesar de não instituído pela Lei ${ }^{\circ} 12.651$, outro dado que deveria fazer parte do CAR são as informaçóes relativas à captaçáo de água subterrânea, poços artesianos e fossas sanitárias. A inclusão dessas informações no CAR só traria vantagens aos proprietários e aos planejadores das políticas públicas, uma vez que, com maiores e melhores informaçóes, poderiam fornecer melhores opçóes para os proprietários.

Defende-se também que o CAR permitirá verificar o tamanho das áreas que deverão ser restauradas, permitindo que projetos de restauração florestal sejam implantados nas melhores áreas, ou seja, naquelas próximas a fragmentos de vegetação, e com técnicas de restauro mais eficazes. Também será possível inserir os projetos de restauração em programas de captura de gases de efeito estufa, contribuindo para a redução da mudança climática. Este arcabouço jurídico ambiental, se devidamente aplicado, pode contribuir em muito para o planejamento e gestão de bacias hidrográficas. 
A Política Nacional de Recursos Hídricos (Lei n 9.433) (BRASIL. Lei 9.433/1997) estabelece o gerenciamento dos recursos hídricos e trata da regulamentação das bacias hidrográficas nacionais através da criação dos Comitês de Bacias Hidrográficas. A Resolução n 5, de 2000 definiu em seu art. $5^{\circ}$ que a área de atuação de cada Comitê de Bacia será estabelecida no decreto de sua instituição.

Instalado em 4 de junho de 1996, o Comitê de Bacia Hidrográfica do Mogi-Guaçu (CBH-MOGI), Unidade de Gerenciamento de Recursos Hídricos $n^{\circ}$ 09, foi instituído pela Lei $n^{\circ} 7.663$ de 1991, segundo a qual fica definida a bacia do rio Claro como uma de suas sub-bacias (SÃO PAULO. Lei 7.663/1991).

No "Plano da Bacia Hidrográfica do Rio Mogi Guaçu 2008 - 2011", foram elencadas as Áreas de Proteção Ambiental (APA) existentes na área da bacia (FEHIDRO, 2011). O Decreto n 20.960 de 1983 trata do estabelecimento da APA Corumbataí, Botucatu e Tejupá (SÃO PAULO. Decreto 20.960/1983), criada com o objetivo de proteger as cuestas basálticas, morros testemunhos das feiçóes geomorfológicas locais, a fauna e flora local, o patrimônio arqueológico e, principalmente, o Aquífero Guarani. Ressalta-se que parte da APA encontra-se na bacia do rio Claro.

$\mathrm{Na}$ esfera estadual, ressalta-se a importância do Decreto n 32.955 de1991, que estabelece em seu art. 19 que o Departamento de Águas e Energia Elétrica (DAEE) e a Companhia de Tecnologia de Saneamento Ambiental (CETESB), quando se fizer necessário restringir a captação e o uso da água, em casos de interesse da conservação, proteção e manutenção do equilíbrio natural das águas subterrâneas, dos serviços de abastecimento de água, ou por motivos geotécnicos ou geológicos, proporão ao Conselho Estadual de Recursos Hídricos a delimitação de áreas destinadas ao seu controle. Sendo que, nessas áreas, a extração de águas subterrâneas poderá ser condicionada à recarga natural ou artificial dos aquíferos (SÃO PAULO. Decreto 32.955/1991).

O referido Decreto ainda define três tipos de áreas de proteção: Área de Proteção Máxima; Área de Restrição e Controle; Área de Proteção de Poços e Outras Captaçóes.

A Área de Proteção Máxima (APM) é compreendida como zonas de recarga de aquíferos altamente vulneráveis à poluição e que se constituam em depósitos de águas essenciais para abastecimento público. Vale salientar que, nessas áreas, fica proibida a implantação de indústrias de alto risco 
ambiental, polos petroquímicos, carboquímicos e cloroquímicos, usinas nucleares e quaisquer outras fontes de grande impacto ambiental, assim como de atividades agrícolas que utilizem produtos tóxicos de grande mobilidade que possam colocar em risco as águas subterrâneas, conforme relação divulgada pela CETESB e pela Secretaria de Agricultura e Abastecimento, bem como o parcelamento do solo urbano sem sistema adequado de tratamento de efluente ou de disposição de resíduos sólidos.

O Decreto ${ }^{\circ} 32.955$ ainda estipula que, em caso de escassez de água subterrânea ou prejuízo sensível aos aproveitamentos existentes nas APM, o DAEE e a CETESB, de acordo com as respectivas atribuiçóes, poderão proibir novas captaçóes até que o aquífero se recupere; restringir e regular a captação de água subterrânea, estabelecendo o volume máximo a ser extraído e o regime de operação; controlar as fontes de poluição existentes mediante programa específico de monitoramento; e restringir novas atividades potencialmente poluidoras. Em âmbito municipal, não foram encontrados dispositivos diferentes ou mais restritivos que os apresentados acima.

\section{Análise da ocupação da bacia do rio Claro face à legislação ambiental}

A análise da Carta de Legislação Ambiental (Figura 3) mostra que, de um total de 25.191 ha, mais de $63 \%$ da bacia encontra-se protegida pela legislação ambiental, sendo 52,73\% Áreas de Proteção Máxima (APM) e $10,35 \%$ Áreas de Preservação Permanente (APP). Dentre as APP, a maior parte $(8,05 \%)$ corresponde a faixas em torno de rios, $0,78 \%$ em torno de nascentes, $0,33 \%$ em torno de lagos e, $1,19 \%$ são topos de morro.

As APM, que são aquelas com potencialidade de recarga do Aquífero Guarani (Botucatu-Pirambóia), foram delimitadas com base nas informaçôes do Mapa de Formaçóes Geológicas de Superfície da Bacia do Rio Claro (SP) (LORANDI et al. 2015). Tais áreas correspondem a 13.281,05 ha da bacia. 


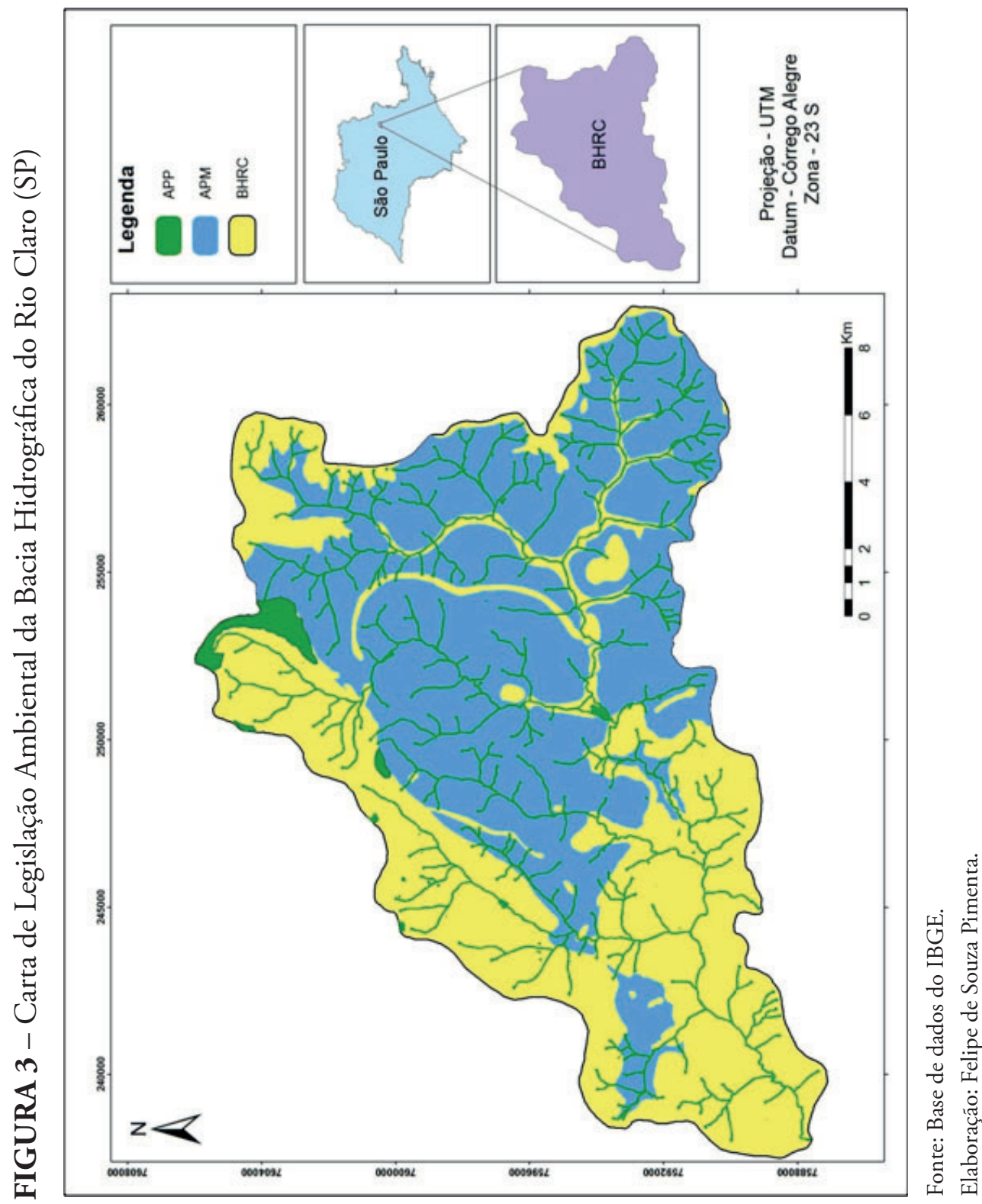

Os resultados da sobreposiçáo dos mapas descrita anteriormente revelam que aproximadamente $97 \%$ da bacia do rio Claro apresentam declividades pouco acentuadas $\left(0-17^{\circ}\right)$ e menos de $3 \%$ apresentam declividades superiores a $17^{\circ}$. Esses valores demonstram o elevado grau de homogeneidade do relevo da bacia, com exceçáo das poucas áreas com declives entre $25^{\circ}$ e $45^{\circ}$, localizadas na porção norte da bacia, nas terras pertencentes às formaçôes geológicas Serra Geral e Botucatu, essa última considerada APM. Os terrenos de mais baixa declividade correspondem às colinas e planícies. 
O Mapa de Uso e Ocupação do Solo da Bacia Hidrográfica do Rio Claro (LORANDI et al., 2015) aponta que, das nove classes de uso e ocupação do solo entre áreas naturais e antropizadas, aproximadamente 32\% da bacia encontra-se ocupada por vegetação nativa, ou seja, mata ciliar ou remanescentes da Floresta Latifoliada Tropical. Quanto aos demais usos e ocupação do solo, $55 \%$ correspondem a atividades antrópicas, tais como a área urbana consolidada (5\%), os cultivos de café (1\%), de cana-de-açúcar (34\%), de laranja (9\%), os reflorestamentos de eucalipto (1\%), áreas de solo exposto (13\%) e ainda áreas de pastagem (4\%).

As áreas com declives acima de $17^{\circ}$ estão cobertas, principalmente, por cultivos de cana-de-açúcar, havendo ainda áreas de solo exposto. Observa-se o avanço da cana, inclusive nas áreas com declives acima de $25^{\circ}$, apesar de a legislação coibir o corte raso nessas áreas. Monteiro (2000) já afirmava que, apesar do Código Florestal de 1965 vetar o controle raso, este deixava uma lacuna na proteção dessas áreas ao tolerar a exploração racional dos recursos florestais, o que pode ter contribuído com o processo de desmatamento da vegetaçáo nativa na bacia do rio Claro. Entende-se que áreas com declives acima de $25^{\circ}$ não deveriam ficar sem cobertura vegetal.

Historicamente, a expansão agropecuária no interior do estado de São Paulo tem se caracterizado por um modelo predatório que acarreta em consequências danosas para a manutenção dos recursos naturais. Um dos mais sérios problemas está na compactação e erosão do solo, decorrentes das técnicas de manejo empregadas, tais como a mecanização. Assim, salienta-se que, além de incorporar técnicas mais adequadas de uso e conservação do solo, os programas agrícolas devem investir na manutenção de remanescentes florestais e matas ciliares.

Segundo Oliveira (1995), uma das razóes da destruição das matas ciliares na regiáo oeste do estado de São Paulo, assim como ocorre em outras regióes do país, é a sua transformação em áreas de pastagem, já que a umidade das várzeas permite melhor desenvolvimento de pastos na estação seca. No entanto, um dos fatores que dependem da preservação das matas ciliares é a manutenção do equilíbrio ecológico, pois a presença da vegetação nativa favorece o controle de pragas nas lavouras e criaçóes (MORAES; LORANDI, 2004).

A mata ciliar é uma formação vegetal associada aos cursos d'água, cuja ocorrência está relacionada com a maior umidade do solo, sendo de 
fundamental importância para a gestão ambiental de bacias hidrográficas, pois além de contribuir para a qualidade da água, exerce o papel de corredor ecológico, facilitando o fluxo genético entre populaçóes, aumentando as chances de sobrevivência, a longo prazo, das comunidades e garantindo a manutençáo dos processos ecológicos e evolutivos (LINDENMAYER; NIX, 1993).

Vale salientar que a presença da mata ciliar ainda permite ao proprietário diminuir os problemas de erosão do solo, manter o volume da água de rios e lagos de sua propriedade, bem como favorecer a sustentação das nascentes durante a estação seca. Tendo como pressuposto os princípios do desenvolvimento sustentável, Sparovek e Lepsch (1995) salientam a necessidade de se estabelecer projetos de uso do solo que garantam não só a manutenção dos ecossistemas, mas também uma produção agrícola sustentável a longo prazo.

Os dados da distribuiçáo do uso e ocupação do solo em APP demonstram que 50,28\% das APP (1.312 ha) não apresentam cobertura vegetal, nem arbórea, nem arbustiva, ou seja, estáo ocupadas por algum tipo de atividade antrópica ou por vegetaçáo herbácea (pastagens ou campos naturais). Por outro lado, 49,72\% da vegetação de porte arbóreo e/ou arbustivo foi identificada como APP preservada, o que perfaz um total de 1.297 ha, ou seja, apenas metade das APP estáo sendo preservadas conforme estabelece a legislação. Como já foi dito anteriormente, dentre as categorias de APP mapeadas na bacia do rio Claro, as mais conservadas ainda são as faixas em torno dos rios.

Deve-se destacar que, dependendo da situação, apenas o cumprimento do Código Florestal não é suficiente para a efetiva proteção ambiental, visto que, em funçáo das peculiaridades regionais ou locais, nem sempre se pode aplicar essa lei como única base legal para a delimitação de APP. Além disso, a delimitação de uma metragem específica não pode ser entendida como um limite além do qual as funçóes ecológicas deixam de operar ou simplesmente deixam de existir.

Os dados da distribuição do uso e ocupação do solo em APM mostram que 4.409,36 ha (em torno de 33\%) dessas áreas estão cobertos por vegetaçáo nativa. Por outro lado, a maior parte, 8.871,69 ha (quase 67\%), está ocupada por atividades agropecuárias ou ainda apresentam solo exposto.

É importante ressaltar que as águas subterrâneas reservadas em aquíferos são fundamentais para o desenvolvimento humano e que a composição química dessas águas é influenciada tanto pelas rochas e sedimentos que conformam os aquíferos como pelas características climáticas ocorren- 
tes nas áreas de recarga. No Brasil, as águas subterrâneas desempenham papel estratégico no abastecimento público e privado, suprindo as mais variadas necessidades de água em cidades e comunidades, assim como em sistemas autônomos residenciais, indústrias, serviços, irrigação de cultivos agrícolas e lazer (LORANDI et al., 2015).

De acordo com a Política Nacional de Recursos Hídricos, a gestão dos recursos hídricos subterrâneos deve fazer parte dos processos de licenciamento ambiental, outorga, cobrança e execução dos planos de bacias hidrográficas (BRASIL. Lei 9.433/1997).

A proteção dos recursos hídricos subterrâneos requer uma atenção especial devido ao seu papel vital no funcionamento dos ecossistemas e para a consolidação do desenvolvimento sustentável (SMITH, 1992), sem falar na sobrevivência das futuras geraçóes; principalmente num momento em que a falta de água de boa qualidade para o abastecimento público tem se tornado cada vez mais presente.

\section{Comentários Finais}

A legislação ambiental incidente sobre a Bacia Hidrográfica do Rio Claro é vasta, mas nenhuma lei municipal traz dispositivos diferentes do Código Florestal, do Código de Águas, da Política Agrícola e da Política Nacional de Recursos Hídricos.

Acredita-se que a Carta de Legislação Ambiental aqui elaborada pode ser útil para direcionar as atividades antrópicas e assegurar a integridade das áreas protegidas pela legislação, especialmente as áreas formadas por vegetação nativa; sendo que a representaçáo espacial das áreas protegidas utilizando um Sistema de Informação Geográfica pode auxiliar no direcionamento dessas atividades.

Em relação às oportunidades, acredita-se que a implantaçáo do CAR pode criar um excelente sistema de gestáo, permitindo a integração de dados das propriedades em relação às APP e aos outros atributos ambientais, que poderiam ser acrescidos de informaçóes para o melhor gerenciamento dos recursos hídricos como a outorga pelo uso da água, localização de poços artesianos e de fossas sépticas.

A utilização do CAR poderá gerar melhores projetos de restauração ecológica, se aliada a projetos de mitigação da mudança climática e de gestão de bacias hidrográficas, contribuindo para a aplicação da legislação e gestão ambiental. 


\section{Referências}

BRASIL. Decreto 24.643, de 10 de julho de 1934. Decreta o Código de Águas.

Disponível em: <http://www.planalto.gov.br/ccivil_03/decreto/d24643. htm>. Acesso em: 15 jun. 2015.

BRASIL. Lei 8.171, de 17 de janeiro de 1991. Dispóe sobre a Política Agrícola. Disponível em: <http://www.planalto.gov.br/ccivil_03/leis/ L8171.htm>. Acesso em: 15 jun. 2015.

BRASIL. Lei 9.433, de 8 de janeiro de 1997. Dispõe sobre a Política Nacional de Recursos Hídricos. Disponível em: <http://www.sigrh.sp. gov.br/sigrh/basecon/Irh2000/indice 1f.htm>. Acesso em: 15 jun. 2015.

BRASIL. Resoluçáo CONAMA 357, de 17 de março de 2005. Dispóe sobre a classificaçáo dos corpos de água e diretrizes ambientais para o seu enquadramento. Disponível: <http://www.mma.gov.br/port/conama/res/ res05/res35705.pdf>. Acesso em: 15 set. 2015.

BRASIL. Lei 12.651, de 25 de maio de 2012. Dispóe sobre o Novo Código Florestal Brasileiro. Disponível em: <http://www.planalto.gov.br/ccivil_03/ato2011-2014/2012/lei/112651.htm>. Acesso em: 15 jun. 2015.

FEHIDRO. Plano da Bacia Hidrográfica 2008-2011. São Paulo: Comitê da Bacia Hidrográfica do Rio Mogi Guaçu/CETESB, 2011.

FEITOSA, F. A. C. et al. (Org.). Hidrogeologia: conceitos e aplicaçóes. Rio de Janeiro: CPRM/LABHID, 2008.

LINDENMAYER, D. V.; NIX, H. A. Ecological principles for the design of wildlife corridors. Conservation Biology, v. 7, n. 3, p. 627-630, 1993.

LORANDI, R. et al. Zoneamento geo(ambiental) da bacia hidrográfica do rio Claro (SP), na escala 1:50.000. Sáo Carlos (SP):

Departamento de Engenharia Civil (CCET/UFSCar). Processo FAPESP 2013/03699-5, 2015.

MAGALHĀES JÚNIOR, A. P. Indicadores ambientais e recursos hídricos: realidade e perspectivas para o Brasil a partir da experiência francesa. Rio de Janeiro: Bertrand Brasil, 2007. 
MONTEIRO, I. S. L. A abordagem ecossistêmica aplicada ao licenciamento de vegetaçáo natural: o caso do município de Descalvado, SP. 2000. 101 f. Tese (Doutorado em Saúde Pública) - Faculdade de Saúde Pública, Universidade de São Paulo, São Paulo, 2000.

MORAES, M. E. B.; LORANDI, R. Análise da efetividade da legislação ambiental brasileira no processo de ocupação de bacias hidrográficas. $\mathrm{O}$ caso da bacia do Rio Bonito (SP). Revista de Direito Ambiental, Sáo Paulo, ano 9, n. 36, p. 151-167, 2004.

OLIVEIRA, H. H. Proposta de criaçáo e caracterização da Área de Proteçáo Ambiental de Descalvado, SP. 1995. 140 f. Dissertação (Mestrado em Ecologia) - Instituto de Biociências, Universidade de Sáo Paulo, São Paulo, 1995.

PIRES, J. S.; SANTOS, J. E. dos; DEL PRETTE, M. E. A utilização do conceito de bacia hidrográfica para a conservaçáo dos recursos naturais. In: SCHIAVETTI, A.; CAMARGO, A. F. M. (Ed.). Conceitos de bacias hidrográficas: teorias e aplicaçôes. Ilhéus: Editus, 2002. p. 17-35.

SÃO PAULO. Decreto 20.960, de 8 de junho de 1983. Declara a Área de Proteção Ambiental Corumbataí, Botucatu e Tejupá. Disponível em: <http:// www.ambiente.sp.gov.br/wp-content/uploads>. Acesso em: 15 jun. 2015.

SÃO PAULO. Decreto 32.955, de 7 de fevereiro de 1991. Regulamenta a Lei 6.134, de 2 de junho de 1988 que dispóe sobre a preservação dos depósitos naturais de águas subterrâneas do Estado de São Paulo, e dá outras providências. Disponível em: <http://www.ambiente.sp.gov.br/ leis_internet/outras_leis/legis_outras.htm>. Acesso em: 15 jun. 2015.

SÃO PAULO. Lei 7.663, de 30 de dezembro de 1991. Estabelece normas de orientação à Política Estadual de Recursos Hídricos, bem como ao Sistema Integrado de Gerenciamento de Recursos Hídricos. Disponível em: http://www.al.sp.gov.br/repositorio/legislacao/lei/1991/lei-766330.12.1991.html Acesso em: 15 jun. 2015.

SÃO PAULO. DAEE-IG-IPT-CPRM. Mapa de águas subterrâneas do Estado de Sáo Paulo. Sáo Paulo: DAEE-Departamento de Águas e Energia Elétrica/IG-Instituto Geológico/IPT-Instituto de Pesquisas Tecnológicas do Estado de São Paulo/CPRM-Serviço Geológico do Brasil, 2005. Escala 1:1.000.000. 
SÃO PAULO. FFLCH/USP-IPT-FAPESP. Mapa geomorfológico do Estado de Sáo Paulo. São Paulo: FFLCH/USP-IPT-FAPESP, 1997. Escala 1:500.000.

SÃO PAULO. IG. Mapa Geológico - Folha Santa Rita do Passa-Quatro (SF-23-V-C-V-1). São Paulo: IG-Instituto Geológico, 1981a. Escala 1:50.000.

SÃO PAULO. IG. Mapa Geológico - Folha Piraçununga (SF-23-VC-V-3). São Paulo: IG-Instituto Geológico, 1981b. Escala 1:50.000.

SÃO PAULO. IG. Mapa Geológico - Folha Descalvado (SF-23-V-CIV-4). São Paulo: IG-Instituto Geológico, 1984. Escala 1:50.000.

SÃO PAULO. IG-DAEE-CETESB. Mapeamento da vulnerabilidade e risco de poluiçáo das águas subterrâneas no Estado de Sáo Paulo. São Paulo: DAEE-Departamento de Águas e Energia Elétrica/IG-Instituto Geológico/

SÃO PAULO. SMA. Macrozoneamento das bacias dos rios Mogi Guaçu, Pardo e Médio Grande: questôes sócio-ambientais e regionais. São Paulo: SMA-Secretaria do Meio Ambiente, 1995. 2 v. Anexo I.

SMITH, L. G. Impact assessment and sustainable resources management. Londres: Longsman, 1992.

SPAROVEK, G.; LEPSCH, I. F. Diagnóstico de uso e aptidão das terras agrícolas de Piracicaba. In: QUEIROZ, T. A. (Org.) Análise ambiental: estratégias e ações. Rio Claro, SP: Fundação Salim Farah Maluf/CEA-UNESP, 1995. p. 273-280. 


\section{Sobre os autores}

\section{Maria Eugênia Bruck de Moraes}

Ecóloga pela Universidade Estadual Paulista (UNESP), Mestre em Ciências da Engenharia Ambiental pela Universidade de São Paulo (USP) e Doutora em Ecologia e Recursos Naturais (UFSCar), com pós-doutorado em Análise e Planejamento Ambiental na UFSCar. Professora e Pesquisadora na Universidade Estadual de Santa Cruz (UESC), vinculada ao Departamento de Ciências Agrárias e Ambientais (DCAA) e ao programa de pós-graduação em Desenvolvimento Regional e Meio Ambiente (PRODEMA).

E-mail para correspondência: eugeniabruck@uesc.br

\section{Reinaldo Lorandi}

Geólogo pela Universidade Estadual Paulista (UNESP), Mestre e Doutor em Solos e Nutrição de Plantas pela Universidade de São Paulo (USP), com especializaçóes em Ensino de Geociências (UNICAMP); Terrenos Sedimentares (UNISINOS) e Planeamento del Territorio (Universidade de La Plata, Argentina). Atualmente é Professor Associado 3 na Universidade Federal de São Carlos (UFSCar).

E-mail para correspondência: lorandir@gmail.com 






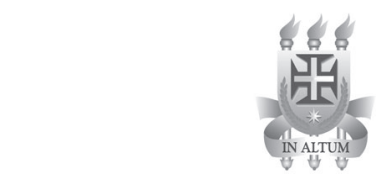

IMPRENSA UNIVERSITÁRIA

Impresso na gráfica da Universidade Estadual de Santa CruZ - Ilhéus-BA 